Финансовый журнал

\section{Научно-практическое издание}

Выходит 6 раз в год. Издается с июля 2009 г.

DOI: $10.31107 / 2075-1990-2020-4$
Toм 12

№ 4

2020

\title{
Тема номера:
}

«Финансирование устойчивого развития в России и в мире»

\section{Главный редактор \\ B. С. Назаров}

директор Научно-исследовательского финансового института

Министерства финансов Российской Федерации,

кандидат экономических наук

\section{Учредитель и издатель}

федеральное государственное бюджетное учреждение «Научно-исследовательский финансовый институт Министерства финансов Российской Федерации»

Адрес: Настасьинский пер., д. 3, стр. 2, Москва 127006, Россия

Тел./факс: (495) 699-74-14

E-mail:mail@nifi.ru

Сайт: www.nifi.ru 
ISSN 2075-1990 (Print), ISSN 2658-5332 (Online).

Свидетельство о регистрации СМИ от 08.05.2019 ПИ № ФС77-75704, выАано ФеАеральной службой по надзору в сфере связи, информационных технологий и массовых коммуникаций (Роскомнадзор).

ИзАание включено в Российский индекс научного цитирования (РИНЦ) с 2009 г.

Журнал вк^ючен в Перечень рецензируемых научных изданий, в которых Аолжны быть опубликованы основные научные результаты диссертаций на соискание ученой степени кандилата наук, на соискание ученой степени доктора наук, по научным специальностям и соответствующим им отраслям науки.

Издание вк^ючено в международный каталог периодических изданий Ulrich's Periodicals Directory, в базу Аанных научных журналов открытого Аоступа Open Academic Journals Index.

Всем статьям присваиваются цифровые идентификаторы объектов - DOI (Digital Object Identifier).

Статьи журнала индексируются в международной базе данных Research Papers in Economics (RePEc).

Тексты всех статей размещаются в открытом доступе на сайте http://www.finjournal-nifi.ru и на портале Научной электронной библиотеки (НЭБ) http://www.elibrary.ru.

\section{Адрес редакции:}

Настасьинский пер., А. 3, стр. 2, Москва 127006, Россия

Те^. (495) 699-76-83

E-mail: finjournal@gmail.com

Сайт: www.finjournal-nifi.ru

Все статьи проходят обязательное научное рецензирование и проверку на отсутствие элементов плагиата. Процедура рецензирования является анонимной и Аля рецензента, и Аля автора. Мнения авторов могут не совпадать с мнением редакции.

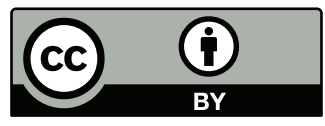

(c) Научно-исследовательский финансовый институт Министерства финансов Российской Федерации, 2020

(C) Financial Research Institute, 2020 


\section{Редакционный совет}

Назаров В. С., кандидат экономических наук, Аиректор НИФИ Минфина России, главный редактор "Финансового журнала" (г. Москва)

Артюхин Р. Е., кандидат юридических наук, руководитель Федерального казначейства (г. Москва)

Бокарев А. А., кандидат экономических наук, Аиректор Аепартамента международных финансовых отношений Министерства финансов Российской Федерации (г. Москва)

Аанчиков Е. А., кандиАат экономических наук, Министр Правительства Москвы, начальник Главного контрольного управления города Москвы (г. Москва)

Ароздов А. В., заслуженный экономист Российской Федерации, заместитель Министра финансов Российской Федерации (г. Москва)
Колычев В. В., заместитель Министра финансов Российской Федерации (г. Москва)

Максимова Н. С., кандидат экономических наук, Аепутат Государственной Аумы Фелерального Собрания Российской Федерации, заместитель председателя Комитета Государственной Аумы по бюАжету и налогам (г. Москва)

Нестеренко Т. Г., кандидат экономических наук, первый заместитель Министра финансов Российской Федерации (г. Москва)

Прокофьев С. Е., Аоктор экономических наук, профессор, заместитель руководителя Федерального казначейства (г. Москва)

Шнейдман $\boldsymbol{\Lambda}$. 3., Аоктор экономических наук, профессор, Аиректор Аепартамента регулирования бухгалтерского учета, финансовой отчетности и аудиторской Аеятельности Министерства финансов Российской Федерации (г. Москва)

\section{Редакционная колмегия}

Алексеев М. В., профессор Инаианского университета (г. Блумингтон, США)

Богачева О. В., кандидат экономических наук, ведущий научный сотрудник Национального исслеАовательского института мировой экономики и межАународных отношений им. Е. М. Примакова РАН (г. Москва)

Герри К. А., профессор Оксфораского университета (г. ОксфорА, Великобритания)

Гурвич Е. Т., кандидат физико-математических наук, руководитель Экономической экспертной группы, член Экономического совета при Презиленте РФ, член Общественного совета при Минфине России (г. Москва)

Гутцайт Е. М., Аоктор экономических наук, веАущий научный сотруАник Центра методологии бухгалтерского учета НИФИ Минфина России (г. Москва)

Аробышевский С. М., Аоктор экономических наук, Аоцент, Аиректор по научной работе Института экономической политики им. Е. Т. Гайдара (г. Москва)
Аэвис К. М., профессор Бирмингемского университета (г. Бирмингем, Великобритания)

Кабир А. С., Аоктор экономических наук, профессор, профессор РАН, главный научный сотрудник Центра межАународных финансов НИФИ Минфина России (г. Москва)

Котиикофф А. А., профессор Бостонского университета (г. Бостон, США)

Назаров В. С., кандидат экономических наук, Аиректор НИФИ Минфина России, главный редактор “Финансового журнала" (г. Москва)

Омельяновский В. В., АОКтор меАицинских наук, профессор, заведующий Аабораторией оценки технологий, в зАравоохранении Института приклаАных экономических исслеАований РАНХиГС (г. Москва)

Пинская М. Р., Аоктор экономических наук, Аоцент, руководитель Центра налоговой политики НИФИ Минфина России (г. Москва) 
Трубин В. В., кандидат экономических наук, эксперт Управления социальной политики Аналитического центра при Правительстве Российской Федерации (г. Москва)

Трунин П. В., Аоктор экономических наук, руководитель научного направления "Макроэкономика и финансы" Института экономической политики им. Е. Т. Гайдара (г. Москва)
Швандар К. В., Аоктор экономических наук, руководитель Центра перспективного финансового планирования, макроэкономического анализа и статистики финансов НИФИ Минфина России (г. Москва)

\section{ИзАательская этика}

Редакция, Редакционная комлегия и Издатель “Финансового журнала" руководствуются общепринятыми международными стандартами этики научных публикаций, разработанными и утвержденными Комитетом по этике научных публикаций (Committee on Publication Ethics СОРЕ) и прилагают все усилия Аля полного их соблюдения. 


\section{Financial

Scientific and Practical Journal

The Journal is issued 6 times a year.

Published since July 2009.

DOI: 10.31107/2075-1990-2020-4

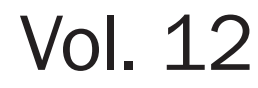

No. 4

2020

\section{Vladimir S. Nazarov. Editor in Chief}

Director of the Financial Research Institute, PhD (Economics)

Founder and Publisher - Financial Research Institute

Address: 3, bldg. 2, Nastasyinsky Lane, Moscow 127006, Russian Federation

Phone: + 74956997414

E-mail: mail@nifi.ru

Website: www.nifi.ru

\section{Editorial Office Address:}

3, bldg. 2, Nastasyinsky Lane, Moscow 127006, Russian Federation

Phone: + 74956997683

E-mail: finjournal@gmail.com

Website: www.finjournal-nifi.ru

\section{Editorial Advisory Board}

V. Nazarov, PhD (Economics), Director of the Financial Research Institute, Editor in Chief of the Financial Journal, (Moscow, Russian Federation)

R. Artyukhin, PhD (Law), Head of the Federal Treasury (Moscow, Russian Federation)

\section{A. Bokarev, PhD (Economics), Head of the Department for International Financial Relations of the Ministry of Finance of the Russian Federation (Moscow, Russian Federation) \\ E. Danchikov, PhD (Economics), Head of the General Control Department of Moscow (Moscow, Russian Federation)}
A. Drozdov, Honoured Economist of the Russian Federation, Deputy Finance Minister of the Russian Federation (Moscow, Russian Federation)

V. Kolychev, Deputy Finance Minister of the Russian Federation (Moscow, Russian Federation)

\begin{abstract}
N. Maksimova, PhD (Economics), Deputy of the State Duma of the Federal Assembly of the Russian Federation, Deputy Chair of the Committee on Budget and Taxes of the State Duma (Moscow, Russian Federation)
\end{abstract}

T. Nesterenko, PhD (Economics), First Deputy Finance Minister of the Russian Federation, (Moscow, Russian Federation)

S. Prokofyev, Doctor of Economics, Professor, Deputy Head of the Federal Treasury (Moscow, Russian Federation)

L. Shneidman, Doctor of Economics, Professor, Head of the Department for Regulation of Accounting, Financial Reporting and Auditing of the Ministry of Finance of the Russian Federation (Moscow, Russian Federation) 


\section{Editorial Board}

Michael V. Alexeev, Professor at Indiana University (Bloomington, USA)

Olga V. Bogacheva, $\mathrm{PhD}$ (Economics), Leading Researcher at the Primakov National Research Institute of World Economy and International Relations (Moscow, Russian Federation)

Christopher J. Gerry, Professor at the University of Oxford (Oxford, United Kingdom)

Evsey T. Gurvich, PhD (Physics and Mathematics), Head of Economic Expert Group, Member of the Economic Council under the President of the Russian Federation, Member of the Public Council at the Ministry of Finance of the Russian Federation (Moscow, Russian Federation)

Evgeny M. Gutzait, Doctor of Economic Sciences, Leading Researcher of the Center for Methodology of Accounting at the Financial Research Institute (Moscow, Russian Federation)

Christopher M. Davis, Professor at the University of Birmingham (Birmingham, United Kingdom)

Sergey M. Drobyshevsky, Doctor of Economic Sciences, Academic Director at Gaidar Institute for Economic Policy (Moscow, Russian Federation)

Ludmila S. Kabir, Doctor of Economic Sciences, Professor, Professor of the Russian Academy of Sciences, Chief Research Associate at the Center for International Finance, Financial Research Institute (Moscow, Russian Federation)
Laurence J. Kotlikoff, Professor at Boston University (Boston, USA)

Vladimir S. Nazarov, PhD (Economics), Director of the Financial Research Institute, Editor in Chief of the Financial Journal, (Moscow, Russian Federation)

Vitaly V. Omelyanovskiy, Doctor of Medical Sciences, Professor, Head of the Laboratory for Health Technology Assessment of the Institute of Applied Economic Research at the Russian Presidential Academy of National Economy and Public Administration (Moscow, Russian Federation)

Milyausha R. Pinskaya, Doctor of Economic Sciences, Head of the Center for Tax Policy of the Financial Research Institute (Moscow, Russian Federation)

Vladimir V. Trubin, PhD (Economics), Expert at the Department for Social Policy of the Analytical Center under the Government of the Russian Federation (Moscow, Russian Federation)

Pavel V. Trunin, Doctor of Economic Sciences, Head of the Macroeconomics and Finance Division at Gaidar Institute for Economic Policy (Moscow, Russian Federation)

Kristina V. Shvandar, Doctor of Economic Sciences, Head of the Advanced Financial Planning, Macroeconomic Analysis and Finance Statistics Center of the Financial Research Institute (Moscow, Russian Federation)

Publishing Ethics. The Editorial Office, Editorial Board and Publisher of the Financial Journal are guided by generally accepted international standards for the ethics of scientific publications developed and approved by the Committee on Publication Ethics (COPE), and make every effort to fully comply with them.

The Journal is included in Ulrich's Periodicals Directory, in Open Academic Journals Index.

Journal articles are indexed in the international database RePEc (Research Papers in Economics).

Articles are published for FREE. All articles are assigned Digital Object Identifiers (DOIs).

The articles are publicly available on the Financial Journal website, www.finjournal-nifi.ru, and at the Scientific Electronic Library portal, www.elibrary.ru.

All articles are reviewed.

Opinions of the authors may not coincide with the opinion of the publisher.

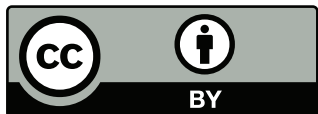


Тема номера: «Финансирование устойчивого развития в России и в мире»

\section{Содержание}

\section{КАиматическая политика}

\section{Ж. А. Мингалева}

Институциональные особенности межАународного финансирования программ аАаптации к климатическим изменениям

И. А. Яковлев, А. С. Кабир, С. И. Никулина

Климатическая политика Российской Федерации:

межАународное сотрудничество и национальный подхоА

Е. П. Федорова

Роль государства в решении проблем развития

"зеленого" финансирования

Механизмы и инструменты развития "зеленой" экономики

С. В. Аорошенко, А. А. Мингалева

Углеродные биржи: европейский опыт развития

механизма торговли разрешениями на выбросы

В. Н. Руцкий, М. В. Осипенко

"Зеленая" экономика как фактор производительности труда

в обрабатывающей промышленности стран Европейского союза

И. П. Аовбий, А. Н. Аегтеренко, В. В. Кобылякова

"Новая индустриализация" в России

как фактор перехода к "зеленой" экономике

\section{Инвестиции в устойчивое развитие}

И. И. Просвирина, Н. С. Аовбий

Выбор источников традиционного и "зеленого" финансирования

наилучших Аоступных технологий

Е. О. Вострикова, А. П. Мешкова

ESG-критерии в инвестировании: зарубежный и отечественный опыт 
Topic of the Issue: Financing Sustainable Development in Russia and Worldwide

\section{Contents}

\section{Climate Policy}

Zh.A. Mingaleva

Institutional Features of International Financing

for Climate Change Adaptation Programs

I.A. Yakovlev, L.S. Kabir, S.I. Nikulina

Climate Policy of the Russian Federation:

International Cooperation and National Approach

E.P. Fedorova

Role of the State in the Resolution

of Green Finance Development Issues

\section{Mechanisms and Tools for Green Economy Development}

S.V. Doroshenko, A.D. Mingaleva

Carbon Exchanges: European Experience

in Developing the Mechanism of Emission Permit Trading

V.N. Rutskiy, M.V. Osipenko

Green Economy as a Labor Productivity Factor

in the Manufacturing Industry of European Union Countries

I.P. Dovbiy, A.N. Degterenko, V.V. Kobilyakova

"New Industrialization" in Russia as a Factor

in the Transition to a Green Economy

\section{Investments in Sustainable Development}

\section{I.I. Prosvirina, N.S. Dovbiy}

Selection of Sources of Traditional and Green Financing

for the Best Available Techniques

E.O. Vostrikova, A.P. Meshkova

ESG Criteria in Investment: Foreign and Russian Experience 


\section{От редакции}

В 2015 г. государства - члены ООН в ответ на глобальные вызовы приняли амбициозные Цели в области устойчивого развития, которые они обязались Аостичь к 2030 г. Основу новой глобальной повестки устойчивого развития составляет перехоА К "зеленой» экономике, предусматривающий внедрение рациональных моделей потребления и производства, расширение использования возобновляемых источников энергии и снижение углеродного следа в произвоАственных цепочках.

Принципы устойчивого развития все шире проникают в сферы управления и бизнеса. Растет число коалиций в различных секторах экономики, объединяющих на глобальном, региональном и страновом уровне государственные и коммерческие структуры с целью разработки новых прави^ ведения Аеятельности, соответствующих принципам устойчивого развития. Несмотря на это, на уровне отдельных стран еще не сложилось окончательного понимания того, какой минии поведения следует придерживаться и какие приоритеты выбрать. Все это в полной мере относится и к Российской Федерации, политика которой в области устойчивого развития еще формируется.

НИФИ Минфина России принимает активное участие в научно-методическом обосновании решений в области интеграции принципов устойчивого развития в национальную стратегию в той ее части, которая относится к механизмам финансирования. Проводится изучение как уже зарекомендовавших себя успешных зарубежных практик, так и нового отечественного опыта. Создана и преАставлена на сайте Минфина России база знаний в этой новой Аля общества сфере. Осуществляется экспертная оценка преАложений различных организаций, разрабатываемых в области финансирования устойчивого развития. Сформирован центр компетенции в области вопросов финансирования устойчивого развития. Так, с марта 2020 г. на базе НИФИ Минфина России и Института экономики УрО РАН функционирует рабочая группа "Зеленые финансы", объединившая исследователей и ученых НИФИ Минфина России, Института экономики УрО РАН и веАущих вузов Уральского федерального округа. Работа в данном направлении имеет цель найти такие решения в области государственного финансирования перехода к устойчивому развитию, которые будут способствовать повышению конкурентоспособности отечественных промышленных преАприятий и модернизации отраслей и секторов национальной экономики.

Этот номер журнала открывает Аискуссию, посвященную отдельным вопросам интеграции принципов устойчивого развития в государственную политику и деловую практику, что является сегодня особенно актуальным. Приглашаем всех заинтересованных лиц присоединиться к экспертной дискуссии как на страницах нашего журнала, так и путем участия в деятельности рабочей группы “Зеленые финансы" и внести свой вклаА в научное обоснование решений по финансированию устойчивого развития в России.

Главный редактор "Финансового журнала" Владимир Назаров 


\title{
Институциональные особенности межАународното финансирования программ адаптации к кАиматическим изменениям
}

\begin{abstract}
Жанна Аркадьевна Мингалева, А. э. Н., профессор кафедры экономики и управления промышленным производством, руководитель центра исследований устойчивого развития и инновационных процессов Пермского национального исследовательского политехнического университета; главный научный сотрудник НИЧ "Агротехнополис" Пермского государственного аграрно-технологического университета им. ак. А. Н. Прянишникова, г. Пермь E-mail: mingal1@pstu.ru, ORCID 0000-0001-7674-7846
\end{abstract}

\begin{abstract}
Аннотация
Статья посвящена анализу основных институциональных механизмов процесса финансирования программ адаптации наименее развитых стран к негативным климатическим изменениям, реализуемых в рамках Рамочной конвенции ООН об изменении климата. Представлены результаты анализа базовых институтов, предназначенных Аля обеспечения процессов финансирования целей устойчивого развития и адаптации к негативным изменениям кмимата, разработанных на международном уровне. Анализ проведен в рамках двух этапов создания и развития системы финансовых институтов межАународной подАержки: Киотского протокола и Парижского соглашения. Выявлены причины необходимости дальнейшей трансформации институциональных механизмов финансирования программ адаптации.

В результате исследования Аоказано, что ключевыми препятствиями Аля успешной реализации финансовых механизмов адаптации является их слабая институциональная основа и наличие колмизий в международных документах по вопросам климатического регулирования и устойчивого развития. На основе институционального анализа показано, что заложенные в основу международных механизмов финансирования институты характеризуются внутренними и внешними противоречиями, обладают слабой способностью к реализации и низкой привлекательностью Аля инвесторов. САелан вывод о том, что ограниченность Аоступа к финансовому капиталу является одной из ключевых причин медленного решения проблемы борьбы с загрязнением окружающей среды и негативными изменениями климата, а также препятствием Аостижению соответствующей цели устойчивого развития.
\end{abstract}

Ключевые слова: финансовые механизмы, программы адаптации, климатические изменения, институты, Рамочная конвенция ООН об изменении климата, Адаптационный фонА

JEL: Q54, Q56, Q58, Q52

Аля цитирования: Мингалева Ж. А. Институциональные особенности международного финансирования программ адаптации к климатическим изменениям // Финансовый журнал. 2020. T. 12. № 4. C. 10-25. DOI: 10.31107/2075-1990-2020-4-10-25. 
DOI: 10.31107/2075-1990-2020-4-10-25

\title{
Institutional Features of International Financing for Climate Change Adaptation Programs
}

\author{
Zhanna A. Mingaleva ${ }^{1,2}$ \\ E-mail: mingal1@pstu.ru, ORCID 0000-0001-7674-7846 \\ ${ }^{1}$ Perm National Research Polytechnic University, Perm 614990, Russian Federation \\ 2 Perm State Agro-Technological University named after Academician D.N. Pryanishnikov, Perm 614990, \\ Russian Federation
}

\begin{abstract}
The article is devoted to analyzing the main institutional mechanisms of the process of financing the programs for the least developed countries' adaptation to negative climate change, implemented within the UN Framework Convention on Climate Change (UNFCCC). The paper presents the results of the analysis of basic institutions designed to support the financing processes for sustainable development and adaptation to negative climate changes developed at the international level. The analysis covers two stages of creating and developing a system of financial institutions for international support: the Kyoto Protocol and the Paris Agreement. The reasons behind the need for further transformation of institutional mechanisms for financing adaptation programs are identified.

As a result of the study, it is concluded that the key obstacles to the successful implementation of financial adaptation mechanisms are their weak institutional basis and the presence of conflicts in international documents on climate regulation and sustainable development. Based on the institutional analysis, it is shown that the institutions that form the core of international financing mechanisms are characterized by internal and external contradictions and have low implementability as well as low attractiveness for investors. It is concluded that limited access to financial capital is one of the key reasons for the slow resolution of the problem of combating environmental pollution and negative climate change as well as achieving the corresponding goal of sustainable development.
\end{abstract}

Keywords: financial mechanisms, adaptation programs, climate change, institutions, UN Framework Convention on Climate Change, Adaptation Fund

JEL: Q54, Q56, Q58, Q52

For citation: Mingaleva Zh.A. Institutional Features of International Financing for Climate Change Adaptation Programs. Financial Journal, 2020, vol. 12, no. 4, pp. 10-25 (In Russ.). DOI: 10.31107/20751990-2020-3-10-25.

\section{BBEAEHИE}

Продвижение к устойчивому развитию общества, к формированию положительных изменений в экологической ситуации на планете в целом и в отАельных регионах мира зависит как от волевых усилий правительств, групп интересов, отАельных ^юАей в соблюАении экологических норм и реализации действий по охране и восстановлению окружающей среды, так и от наличия достаточного объема финансовых ресурсов для осуществления необходимых мероприятий и от эффективности распределения средств межАу направмениями, субъектами и объектами финансирования программ по борьбе с негативными изменениями климата [Weiler F. et al., 2018]. 
Вопросы финансирования расходов на борьбу с загрязнением окружающей среды и Аля Аостижения соответствующих целей устойчивого развития ${ }^{1}$ начали решаться уже на первых этапах принятия и реализации международных программ в области изменения климата [Smit B. et al., 1999]. При этом перечень областей Аеятельности и вопросов, попавших в сферу ответственности создаваемого рамочного механизма Аля реализации глобальных мер в связи с изменением климата, включает координацию усилий отдельных стран и международных организаций по четырем основным направлениям Аеятельности: адаптация к изменению климата, предотвращение изменения климата, создание климатически безопасных технологий и финансирование программ в области климата.

Основные задачи, направления, принципы, порядок функционирования институтов финансирования адаптации к изменениям климата и противодействия его негативного влияния были разработаны в конце XX в. в рамках деятельности Межправительственной группы экспертов по изменению климата, созданной в 1988 г., а также Рамочной конвенции об изменении климата Организации Объединенных Наций (РКИК ООН), официально вступившей в силу в 1994 г. Аальнейшее формирование институциональной системы финансирования мероприятий по борьбе с климатическими изменениями шло в рамках соответствующего направления деятельности различных институтов ООН. Так, уже на следующий год в Берлине прошла первая Конференция сторон по изменению климата (так называемая KC-1), а в 1996 г. был создан секретариат РКИК ООН Аля оказания поААержки деятельности, осуществляемой в рамках конвенции. Завершением подготовительного этапа можно считать прошедшую в декабре 1997 г. КС-3, в ходе которой был официально принят Киотский протокол.

\section{МЕХАНИЗМЫ ФИНАНСИРОВАНИЯ ПРОГРАММ АААПТАЦИИ К КАИМАТИЧЕСКИМ ИЗМЕНЕНИЯМ В РАМКАХ КИОТСКОГО ПРОТОКОАА}

В рамках РКИК ООН и Киотского протокола были созданы основные современные международные институты и механизмы финансирования расходов на адаптацию стран $\mathrm{k}$ климатическим изменениям, на борьбу с климатическими изменениями и ликвидацией послеАствий от экологических аварий и стихийных беАствий. ОАнако возможность реального применения этих финансовых механизмов была в значительной степени ограничена отсутствием адекватных национальных и международных институтов, регулирующих процессы аккумулирования и распределения финансовых ресурсов [Flåm, K. H., Skjærseth, J. B., 2009]. В число серьезных недостатков институционального механизма финансирования аАаптационных программ на первом этапе реализации попали проблемы слабого уровня соответствия критериев отбора проектов Аля финансирования помитики адаптации тем реальным институциональным возможностям наименее развитых стран, которые были в этих странах на момент запуска РКИК ООН и Киотского протокола, а также отсутствие согласованных между всеми сторонами правил отбора направлений и программ Аля финансирования. Серьезным препятствием Аля активного осуществления мероприятий по финансированию программ аАаптации к изменению климата и борьбы с кмиматическими изменениями (вкмючая их предотвращение) на первых этапах стал и меАленный процесс согласования и ратификации всеми сторонами многосторонних межаународных Аоговоренностей, обусловленный наличием серьезных разногласий межАу странами о порядке и правилах распределения ресурсов [Brechin S. R.,

1 Борьба с изменением климата зафиксирована в Аокументах ООН в качестве официальной цели устойчивого развития (ЦУР 13 “Борьба с изменением климата»). UNFCCC - 25 Years of Effort and Achievement. Key Milestones in the Evolution of International Climate Policy. URL: https://unfccc.int/process/the-convention/historyof-the-convention. 
Espinoza M. І., 2017]. Еще одним саерживающим фактором оказалась низкая активность различных стран (как высокоразвитых, так и развивающихся) в реализации целей устойчивого развития и финансирования мероприятий по борьбе с изменением климата, поскольку не были созданы адекватные механизмы сбора и распределения финансовых среАств межАу отАельными странами и программами аАаптации к изменениям климата [Bouwer L. M., Aerts J. C., 2006].

В результате в 2001 г. на КС-7 были утверждены так называемые Марракешские Аоговоренности, в рамках которых было принято решение о созАании нового порядка планирования процесса адаптации наименее развитых стран к климатическим изменениям, а также о разработке инструментов финансирования такой адаптации. ОАним из важнейших способов адаптации была утверждена концепция передачи технологий. ОАнако первоначально и эти механизмы не получили нужной институциональной подАержки и развития [Hof A. F. et al., 2009]. В частности, ААаптационный фонА содействия развивающимся странам, решение о созАании которого было принято на КС-7 в 2001 г., начал свою Аеятельность только в 2008 г., после соответствующего решения КС-13, состоявшейся в 2007 г. на острове Бали (Индонезия), а официальным началом финансовой Аеятельности фонда является Аата 27 февраля 2009 г.

Целью Аеятельности ААаптационного фонда, созданного специально Аля финансовой подАержки тех из наименее развитых стран, которые особенно уязвимы переА лицом неблагоприятных послеАствий изменения климата, является аккумулирование финансовых ресурсов и выделение среАств Аля покрытия расходов, связанных с адаптацией этих стран к климатическим изменениям, в том числе Аля оказания помощи развивающимся странам в разработке национальных планов действий по преодолению послеАствий негативных экологических явлений и беАствий. В соответствии с первоначальными планами ААаптационный фонА Аолжен был стать основным механизмом прямого Аоступа, позволяющим развивающимся странам получить доступ к необходимым финансовым среАствам без посреАничества различных многосторонних агентств развития.

ААаптационный фонА является специальным финансовым институтом, преАназначенным Аля перераспределения средств, полученных от реализации высокоразвитыми странами мероприятий по борьбе с загрязнением окружающей среды, в пользу финансовой поддержки наименее развитых стран, подверженных наибольшему негативному воздействию от изменения климата.

В качестве основного источника формирования средств ААаптационного фонда первоначально были заложены поступления от продажи так называемых сертификатов сокращений выбросов (CCB) (certified emissions reductions (CERs) credits), введенных в систему инструментов климатического регулирования в рамках Механизма чистого развития (Clean Development Mechanism) [Klein R. J. T., 2014, p. 915]. В соответствии с правилами финансирования фонда на его счета зачисляется 2 \% CCB, зарегистрированных в рамках Механизма чистого развития, которые затем монетизируются на углеродном рынке. В качестве второго базового источника доходов ААаптационного фонда были предусмотрены целевые взносы на адаптацию от правительств развитых стран [Ayers J., Huq S., 2009]. В качестве третьего источника (на более позАних этапах, когАа произойдет накопление средств) предполагалось использовать финансовые ресурсы, аккумулированные в виле чистого инвестиционного АохоАа.

Анализ показал, что первые Ава года Аеятельности ААаптационного фонда процесс монетизации ССВ проходил в крупных объемах и поступления от монетизации составляли практически 65 \% всех финансовых Аоходов фонда (см. рис. 1-2). ОАнако после 2011 года, когАа произошло снижение цен на сертификаты, объем выручки по Аанной статье Аоходов резко упал: с 57,1 млрА Аомл. в 2010/11 финансовом году Ао 16,9 млрА Аомм. в 2011/12 финансовом году (т. е. практически в 3,3 раза за один финансовый гоА) 
и проАолжал ежегодно сокращаться, Аостигнув минимума в 2 млрА Аолл. (или 2,6 \% от всех поступлений) в 2013/14 финансовом году. ОАновременно это привело и к существенному сокращению общего объема поступлений в ААаптационный фонА (см. рис. 1).

Рисунок 1

\section{Аинамика поступлений от монетизации ССВ}

и общего дохода ААаптационного фонда в 2009-2016 гг., тыс. Аом. США /

Dynamics of revenues from monetization of the deposit insurance and the total income of the Adaptation Fund in 2009-2016, thousand USD

Тыс. АОМ .

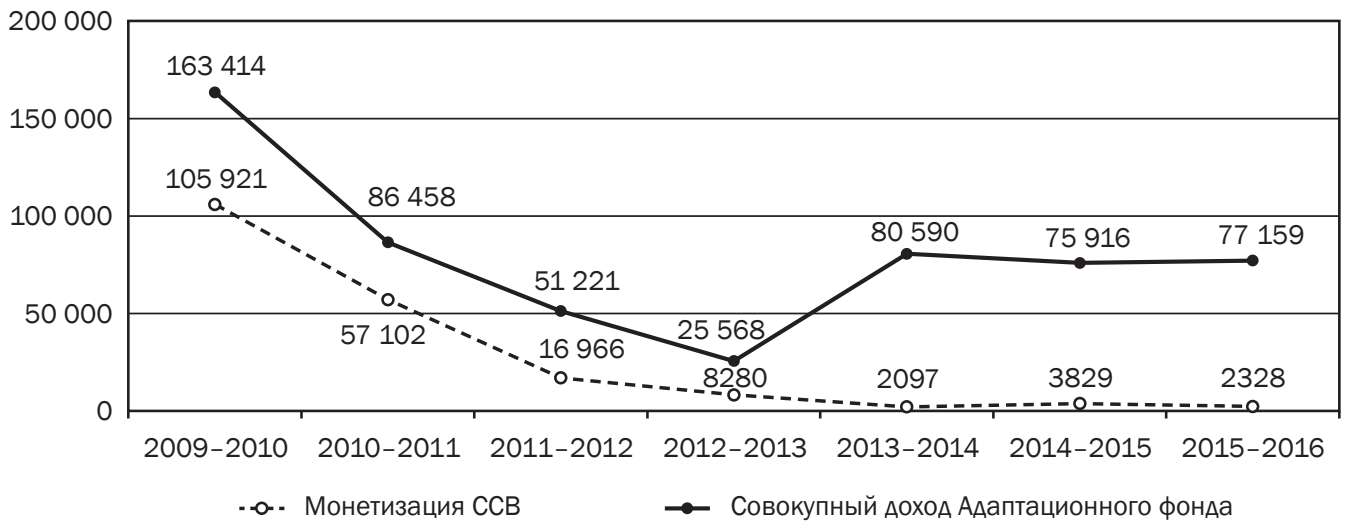

Источник: составлено автором по ежегодным отчетам Трастового фонда Адаптационного фонда / Source: compiled by the author based on the Annual Reports of the Adaptation Fund's Trust Fund (https://fiftrustee. worldbank.org/en/about/unit/dfi/fiftrustee/reports?fundName=ADAPT).

Соответственно изменилась и структура источников поступлений в фонА. Начиная с 2012 г. преобладающими стали средства, передаваемые правительствами развитых стран в виде Аобровольных ежегодных взносов. Так, в 2013/14 финансовом году удельный вес добровольных взносов в общем объеме поступлений в ААаптационный фонА Аостиг 96,2% и в последующие годы оставался примерно на таком же уровне (рис. 2).

Структура поступлений в Адаптационный фонд в 2009-2016 гг., \% / The structure of revenues to the Adaptation Fund in 2009-2016, \%

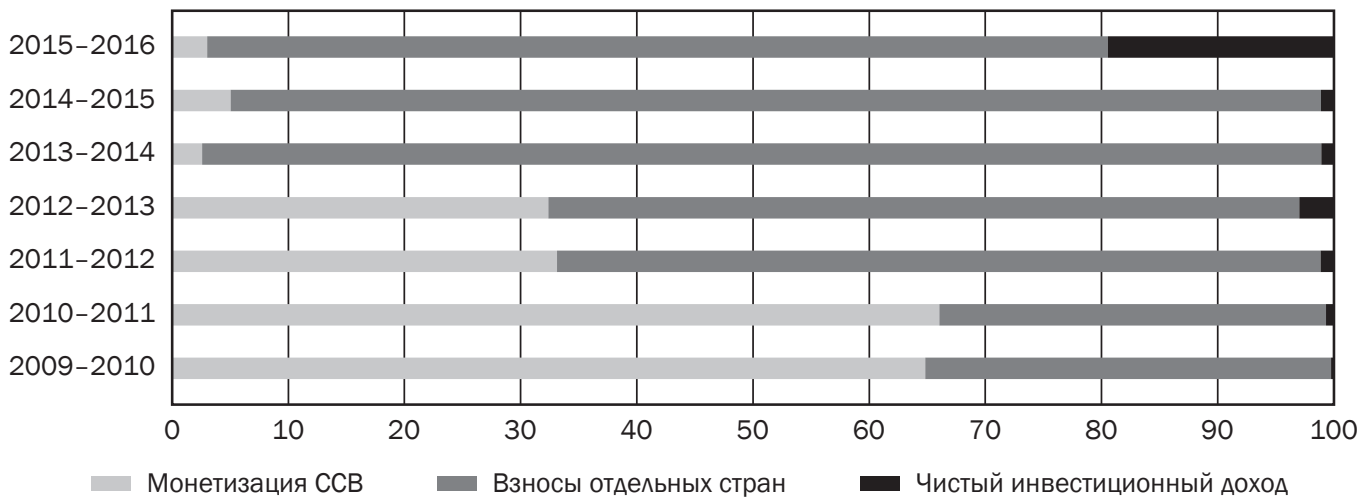

Источник: составлено автором по ежегодным отчетам Трастового фонда ААаптационного фонда / Source: compiled by the author based on the Annual Reports of the Adaptation Fund's Trust Fund (https://fiftrustee. worldbank.org/en/about/unit/dfi/fiftrustee/reports?fundName=ADAPT). 
В результате сформировалась Аостаточно сложная в политическом и финансовом отношении ситуация, когАа механизм перераспределения среАств с углеродного рынка (исходно заложенный в виде основного в Аанную систему) практически потерял свое значение, а средства Аля нужА адаптации начали формироваться преимущественно за счет взносов, предоставляемых на Аобровольной основе развитыми странами [Berrang-Ford L. et al., 2014; Berrang-Ford L. et al., 2019]. При этом объем ежегодно выделяемых взносов зависит от политики правительств конкретных стран.

Таким образом, основной институциональный механизм финансирования программ устойчивого развития и решения задач климатического регулирования, опирающийся в первую очередь на Аеятельность ААаптационного фонда (на его Аолю в начале текущего Аесятилетия приходилось почти 40 \% всех среАств по климатическому регулированию), не смог аАекватно выполнять закрепленные за ним функции по стимулированию активности отАельных стран и групп стран в борьбе с негативными тенденциями в изменении климата. Соотношение среАств различных фондов в общей структуре базовых финансовых институтов в период Аействия Киотского протокола (в объеме климатического финансирования в 2011 и 2013 гг.) приведено на рис. 3.

\section{Соотношение вклада различных фондов}

Рисунок 3

\section{в кяиматическое финансирование в 2011 и 2013 гг., \% /}

\section{The ratio of the contribution of various funds to climate finance in 2011 and 2013, \%}

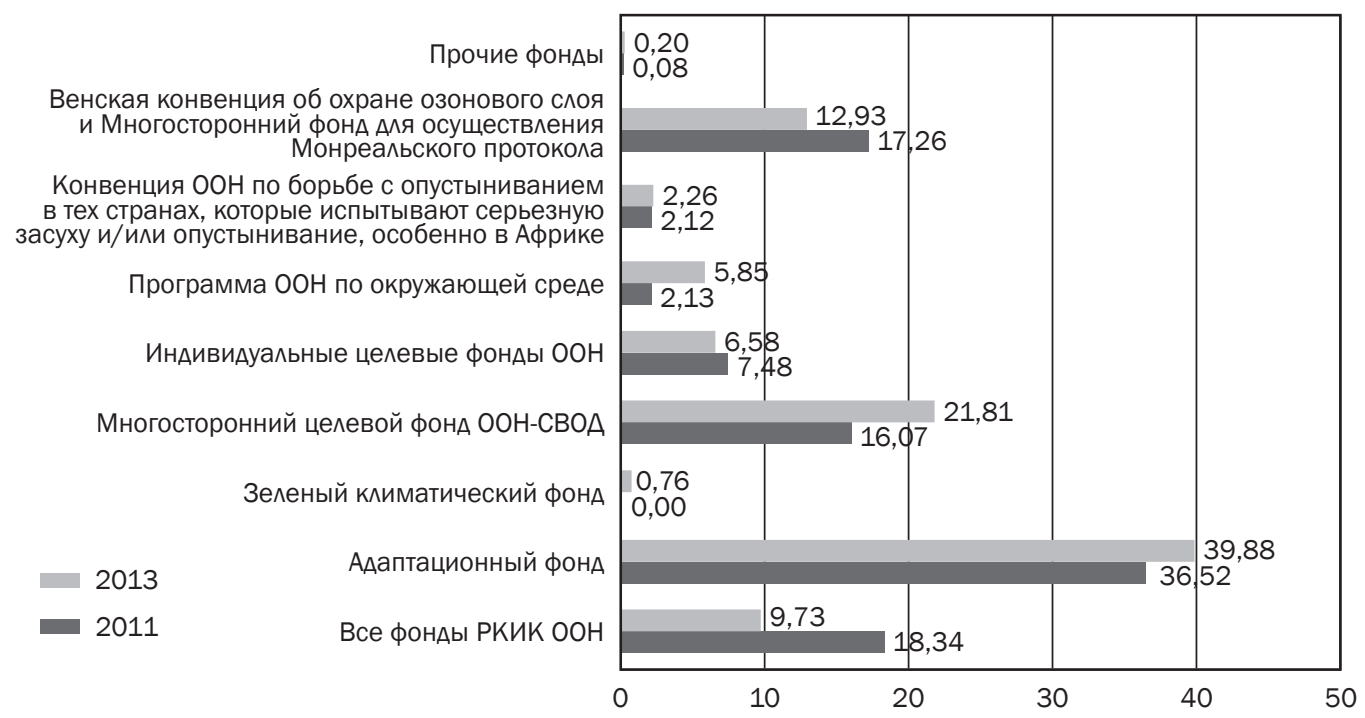

Источник: составлено автором по [Казо Ж.-У. и др., 2015, с. 52-55] / Source: compiled by the author on the [Cazo J.U. et al., 2015, pp. 52].

В то же время по итогам 22-го заседания совета ААаптационного фонда в 2013 г. $^{2}$ было определено, что потребности в финансировании программ аАаптации продолжали возрастать, а объем средств сокращался. Это закономерно привело к объективной необхоАимости трансформации институциональных механизмов финансирования программ аАаптации к изменению климата, которая была осуществлена в рамках подготовки Парижского соглашения, принятого в рамках 2-й Конференции сторон по изменению климата в ноябре 2015 г. в Париже (COP 21) [Jones R. N. et al., 2014; Noble I. R. et al., 2014].

2 Отчет о Авадцать втором заседании совета ААаптационного фонда. URL: http://www.adaptation-fund.org/ wp-content/uploads/2015/01/AFB22\%20Report\%20(Russian).pdf. 


\section{ФОРМИРОВАНИЕ СОВРЕМЕННЫХ ИНСТИТУЦИОНААЬНЫХ МЕХАНИЗМОВ ФИНАНСИРОВАНИЯ ПРОГРАММ АААПТАЦИИ К ИЗМЕНЕНИЮ КАИМАТА В РАМКАХ ПАРИЖСКОГО СОГААШЕНИЯ}

Вступление в силу 4 ноября 2016 г. Парижского соглашения ознаменовало начало нового этапа осуществления конкретных Аействий, направленных на борьбу с изменением климата и достижение целей устойчивого развития. K числу таких Аействий относится и расширение системы институциональных механизмов финансирования инвестиций на цели, связанные с изменением климата.

Переходный этап корректировки Киотского протокола по вопросам создания более эффективной системы финансирования устойчивого развития и решения задач климатического регулирования на основе международных институтов РКИК ООН включал разработку и продвижение Аурбанской платформы ${ }^{3}$, создание и начало работы Зеленого климатического фонда ${ }^{4}$, созАание и запуск механизма по Аолгосрочному финансированию - Варшавского международного механизма по убыткам и ущербу5. Кроме того, в этот период велась активная работа по улучшению деятельности ААаптационного фонАа, который Аолжен бы^ органично вписаться в новую систему финансовых институтов в рамках общей концепции устойчивого развития ${ }^{6}$.

Особое место в новой системе финансовых институтов РКИК ООН, направленных на подАержку программ аАаптации к климатическим изменениям, было отведено Варшавскому международному механизму по убыткам и ущербу (ВММУУ), а его высокая значимость Аля всего механизма климатического регулирования была определена теми целями, задачами и функциями, которые были предусмотрены международными соглашениями по его созданию. В общем виде Варшавский международный механизм призван выполнять методологическую, информационную, координационную, распределительную функции, что определяет его большую значимость в системе институтов борьбы с загрязнением окружающей среды и выполнением требований Киотского протокола и Парижского соглашения.

В рамках выполнения этих функций и ключевой задачи деятельности ВММУУ призван обеспечивать более надежное и эффективное взаимодействие между всеми сторонами РКИК ООН, соответствующими институтами, специализированными учреждениями, а также различными международными организациями по всему спектру вопросов, нахоАящихся в его веАении, включая вопросы предупреждения и ликвиАации послеАствий экстремальных событий, Аопускаемых отАельными странами и приводящих к неблагоприятным последствиям изменения климата. Таким образом, к числу решаемых ВММУУ заАач относится и задача создания и развития специализированных учрежАений (институтов) на региональном и на национальном уровнях в развивающихся странах, а также в наиболее уязвимых в экологическом отношении регионах. Эти специализированные учреждения Аолжны обеспечивать сотрудничество и координацию Аеятельности субъектов в области охраны окружающей среды, способствовать активизации инициатив конкретных стран по борьбе с загрязнением окружающей среды, поощрять сотрудничество между всеми заинтересованными сторонами в решении проблем, связанных с потерями и ущербом,

\footnotetext{
3 Решение, принятое на 17-й Конференции сторон (СОР 17) в Аурбане, Южная Африка, 2011 г.

4 Решение о созАании фонда принято на 18-й Конференции сторон (СОР 18) в Канкуне, Мексика, 2012 г. В данной статье правовое положение, порядок Аеятельности, проблемы в функционировании и перспективы развития Зеленого климатического фонда анализироваться не будут.

5 Решение, принятое на 19-й Конференции сторон (СОР 19) в Варшаве, Польша, 2013 г.

${ }^{6}$ Не рассматривая дальнейшую Аеятельность ААаптационного фонда содействия развивающимся странам более подробно, отметим, что фонд был утвержден в качестве одного из формальных инструментов достижения целей Парижского климатического соглашении в рамках 23-й сессии Конференции сторон Рамочной конвенции ООН об изменении климата (СОР 23), которая прошла 6-17 ноября 2017 г. в Бонне.
} 
а также собирать, аккумулировать и расширять потоки информации о возникающих потерях и величине ущерба.

Важной функцией Варшавского межАународного механизма является стимулирование представителей развитых стран мира к предоставлению развивающимся странам размичных виАов помощи, оказанию им прямого финансирования в рамках экологических программ, передаче экологически безопасных технологий, поощрению иных действий по созданию и укреплению потенциала развивающихся стран в борьбе с загрязнением окружающей среды. С этой целью предусматривается создание механизма мобилизации и обеспечения экспортного потенциала технологий, разработка методов, управленческих решений и руководящих указаний с целью реализации существующих поАХоАов к решению проблем, обусловленных возникновением потерь и ущерба вследствие негативного изменения климата, а также вопросов выделения необходимых финансовых средств на эти цели [Hinkel J. et al., 2013].

Также на Варшавский международный механизм возлагается задача информационного обеспечения деятельности по борьбе с загрязнением окружающей среды всех участников РКИК ООН, вк^ючая сбор, обработку, анализ, хранение и распространение информации о фактических потерях и возникшем ущербе, разработку рекоменАаций по уменьшению рисков, потерь и ущерба от загрязнения окружающей среды и подготовку руководящих указаний по применению этих рекомендаций.

Анализируя результаты работы Варшавского международного механизма по потерям и ущербу с момента принятия формального решения о его создании на СОР 19 в 2013 г. и официального начала действия после принятия Парижского соглашения в 2016 г., нужно отметить, что реально Аействующего механизма пока нет. Существующий в настоящее время вариант организации работы Варшавского международного механизма по потерям и ущербу не в состоянии обеспечить эффективную Аеятельность по сбору среАств Аля покрытия климатических ущербов в силу элементарной нехватки источников финансирования. Этот вывод подтвердили и результаты анализа рабочих материалов всех последующих конференций по климатическим изменениям, включая последнюю из состоявшихся к сегодняшнему Аню 25-ю Климатическую конференцию (СОР 25) в Мюнхене в Аекабре 2019 г. Анализ материалов работы конференции показал, что вопросы финансирования проектов по адаптации, вопросы оценки и компенсации потерь и ущерба от наблюАаемых послеАствий изменения климата и Аругие направления финансирования остались за рамками активного обсуждения. Аостижения согласия по этим вопросам между всеми участниками СОР 25 не произошло. Наблюдателями и экспертами отмечается, что на конференции в Мюнхене основные переговоры были сосредоточены на обсуждении мероприятий по снижению выбросов и распределению ответственности между странами и группами стран за эти выбросы, на вопросах создания рынка выбросов, определении квот на загрязнение, установлении цены мицензии и т. А. В то же время в обсуждении мало уделялось внимания такому аспекту $\mathrm{NDCs}^{7}$, как создание и реализация комплекса мер по аАаптации, финансированию, передаче технологий и др.

Оценивая важность и значимость международного механизма по убыткам и ущербу, принятого в Варшаве, нужно отметить, что одной из задач Варшавского международного механизма являлась адаптация существующих финансовых институтов к принятию новых Аокументов по изменению климата, которые Аолжны были прийти на смену Киотскому протоколу и которые были приняты в 2015 г. на СОР 21 в Париже. ОАнако, как показал анализ последующего развития событий, и здесь были допущены ошибки в трансформации институциональной составляющей проводимых реформ, а разработка основы Аля справеАливого и эффективного распреАеления средств на адаптацию Аля развивающихся

7 Вклад каждой страны в борьбу с изменением климата, определяемый на национальном уровне. 
стран Ао сих пор остается "нетривиальной задачей" [Smith J. B. et al., 2009; Barr R. et al., 2010; Andrijevic M. et al., 2020].

\section{ИНСТИТУЦИОНААЬНЫЕ ПРОБАЕМЫ В АЕЯТЕАЬНОСТИ МЕЖАУНАРОАНЫХ МЕХАНИЗМОВ ФИНАНСИРОВАНИЯ БОРЬБЫ С КАИМАТИЧЕСКИМИ ИЗМЕНЕНИЯМИ}

Реальное и эффективное выполнение задачи справедливого и эффективного распределения среАств на аАаптацию Аля развивающихся стран преАполагает создание адекватных институциональных условий Аля Аеятельности соответствующих финансовых механизмов [Klein R. J. T. et al., 2014]. Анализ практики функционирования ААаптационного фонАа, Варшавского межАународного механизма, Зеленого кмиматического фонда и ряда других финансовых механизмов в области борьбы с изменением климата показал наличие целого ряда институциональных проблем, препятствующих их эффективной деятельности. В частности, речь илет о колмизиях в международных и национальных Аокументах, а также о наличии серьезных пробелов и противоречий в методологических поАХоАах к регулированию деятельности по адаптации к климатическим изменениям.

Во-первых, после соответствующей корректировки Киотского протокола и принятия в 2015 г. Парижского соглашения произошло изменение подхоАа к понятию "развитые и развивающиеся страны", лежащему в основе деятельности базовых институтов и фондов РКИК ООН, - из официальных списков было удалено понятие "развитые и развивающиеся страны". Этот факт сразу же был использован и сейчас широко используется многими странами - потенциальными Аонорами - как аргумент об отсутствии четкого указания на то, кто кому Аолжен платить. В настоящее время многие страны, наиболее сильно подверженные последствиям климатических изменений, формально (по классификации Всемирного банка) относятся к категории стран "со средним Аоходом", и им уже не помагается безвозмезАной климатической помощи. С Аругой стороны, при таком подходе в категорию развивающихся стран попадают отнюдь не беднейшие страны и регионы. В частности, программами аАаптации в настоящее время широко пользуются аАминистрации депрессионных городов высокоразвитых стран, особенно США (например, Аетройт, Мичиган и КмивленА) [Hughes S., 2020], а бенефициарами финансовой помощи становятся национальные фонды этих стран. Так, около 70 \% всех выплат ААаптационного фонда за период 2009-2016 гг. осуществлено трем крупнейшим программам $\mathrm{OOH}$ (Программа развития, Программа ООН по окружающей среде и Всемирная проАовольственная программа), которые являются промежуточными институтами Аля Аальнейшего перераспределения средств (табл. 1). Средства, полученные непосреАственно развивающимися странами, в десятки раз меньше.

Таблица 1

Структура реципиентов Адаптационного фонда

и сумма перечисленных им денежных выплат за 2009-2016 гг., тыс. дом. США / The structure of recipients of the Adaptation Fund and the amount of its cash payments in 2009-2016, thousand USD

\begin{tabular}{|l|c|c|c|}
\hline \multicolumn{1}{|c|}{$\begin{array}{c}\text { Получатели Аенежных выплат } \\
\text { из средств Алаптационного фонда }\end{array}$} & $\begin{array}{c}\text { Выплаты Аля } \\
\text { реализации } \\
\text { проектов } \\
\text { по алаптации }\end{array}$ & $\begin{array}{c}\text { Выплаты для } \\
\text { проведения } \\
\text { наблюдения } \\
\text { за адаптацией }\end{array}$ & $\begin{array}{c}\text { Итого по всем } \\
\text { направлениям } \\
\text { выплат }\end{array}$ \\
\hline $\begin{array}{l}\text { Национальное агентство по исследованиям и инновациям, } \\
\text { Мексика }\end{array}$ & 5471794 & 297750 & 5769544 \\
\hline Центральный банк Республики Аргентина & 1899611 & 92377 & 1991988 \\
\hline Агентство по развитию сельского хозяйства, Марокко & 2666862 & 271060 & 2937922 \\
\hline Центр экологического мониторинга, Сенегал & 8628837 & 325000 & 8953837 \\
\hline $\begin{array}{l}\text { Фонд сотрудничества в целях устойчивого развития, } \\
\text { Коста-Рика }\end{array}$ & 1524877 & 146682 & 1671559 \\
\hline
\end{tabular}




\begin{tabular}{|c|c|c|c|}
\hline $\begin{array}{c}\text { Получатели Аенежных выплат } \\
\text { из среАств ААаптационного фонАа }\end{array}$ & $\begin{array}{c}\text { Выплаты Аля } \\
\text { реализации } \\
\text { проектов } \\
\text { по адаптации }\end{array}$ & $\begin{array}{c}\text { Выплаты Аля } \\
\text { проведения } \\
\text { наблюАения } \\
\text { за аАаптацией }\end{array}$ & $\begin{array}{c}\text { Итого по всем } \\
\text { направлениям } \\
\text { выплат }\end{array}$ \\
\hline МежАународный банк реконструкции и развития & 3428310 & 265154 & 3693464 \\
\hline МежАунароАный фонА сельскохозяйственного развития & 1464700 & 124500 & 1589200 \\
\hline Агентство межАународного сотрудничества, Чили & 1839899 & 100075 & 1939974 \\
\hline Министерство природных ресурсов Руанды & 6653051 & 301319 & 6954370 \\
\hline $\begin{array}{l}\text { Министерство пяанирования и международного } \\
\text { сотрудничества, Иордания }\end{array}$ & 1748527 & 146166 & 1894693 \\
\hline $\begin{array}{l}\text { Национальный банк сельского хозяйства и развития сельских } \\
\text { районов, Индия }\end{array}$ & 1607285 & 132717 & 1740002 \\
\hline $\begin{array}{l}\text { Национальный орган по управлению окружающей средой, } \\
\text { Кения }\end{array}$ & 4646906 & 310000 & 4956906 \\
\hline Институт планирования Ямайки & 5550750 & 459610 & 6010360 \\
\hline Национальный институт биоразнообразия Южной Африки & 1085978 & 37336 & 1123314 \\
\hline ЕАиница сельских изменений, Аргентина & 2276738 & 75535 & 2352273 \\
\hline Программа развития ООН & 79252737 & 8264473 & 87517210 \\
\hline Программа ООН по окружающей среде & 10087898 & 848972 & 10936870 \\
\hline Всемирная продовольственная программа ООН & 16174520 & 1429617 & 17604137 \\
\hline ФонА природы Панамы & 20000 & 0 & 20000 \\
\hline Микронезийский фонА охраны природы & 20000 & 0 & 20000 \\
\hline Национальный экологический фонА, Бенин & 49000 & 0 & 49000 \\
\hline Западноафриканский банк развития & 20000 & 0 & 20000 \\
\hline Всего, выплаты из ААаптационного фонАа & 156118280 & 13628343 & 169746623 \\
\hline
\end{tabular}

Источник: составлено автором по Adaptation Fund's Trust Fund: Financial Statement and Independent Auditors' Report. The World Bank Group, 2016, p. 6-7 / Source: compiled by the author based on the Adaptation Fund's Trust Fund: Financial Statement and Independent Auditors' Report. The World Bank Group, 2016, pp. 6-7.

Как виАно из Аанных табл. 1, на фонды самой ООН приходится более 70 \% всех денежных выплат из ААаптационного фонда за период его Аействия с 2009 по 2016 г., в то время как на организации и учреждения наиболее бедных развивающихся стран (таких как Бенин, Кения, Ямайка, Руанда, Сенегал и лр.) - только 20 \% (оставшиеся 10 \% приходятся на финансовую подАержку адаптационных программ в Аргентине, Индии, Мексике). Что же касается таких форм финансирования, как займы, ссуды, субсидии, иные косвенные стимулы, то эти инструменты климатического финансирования некоторые "условно" развитые страны-доноры стараются зачесть себе как выделенное ими климатическое финансирование.

Во-вторых, серьезные ограничения Аля механизмов и институтов климатического финансирования создает узкое и ограниченное Аля практического применения понятие убытков и ущерба, закрепленное в международных документах РКИК ООН [Mace М. J., Verheyen R., 2016]. Так, в Варшавском международном механизме, а затем и в Парижском соглашении под ущербом и убытками подразумеваются только те необратимые изменения, которые испытывают развивающиеся страны и островные государства, нахоАящиеся в регионах, подверженных климатическим катаклизмам. При этом под Аанное определение не попадают ущерб и убытки, которые несет окружающая среда развитых стран в результате мюбых климатических бедствий. Исходный посы^ рассуждений инициаторов такого подхода понятен - в Аанный механизм заложена илея безвозмездной финансовой подАержки наименее развитым странам со стороны развитых. ОАнако на практике такой подхоА существенно снизил интерес к Аанному механизму потенциальных инвесторов аАаптационных программ, что и привело к их слабому финансированию.

В-третьих, отсутствие у ряда межАународных финансовых механизмов явно выраженной эффективности и прибыльности. Особенностью большинства аАаптационных 
проектов, финансирование которых предусмотрено правилами основных международных Аоговоренностей по климатическому регулированию, является то, что в ходе их реамизации практически никогАа не создается прибыль или иной финансовый АохоА. В силу этого они являются слабопривлекательными как Аля самих инвесторов из развивающихся стран и островных государств, так и из стран-доноров [Weiler F. et al., 2018]. Например, оценивая перспективы привлечения средств программы "Официальная помощь в целях развития" (ОПР) Аля финансирования климатических проектов, многие исследователи отмечают наличие различных ограничений, связанных с возможностью использования Аанного механизма Аля программ адаптации. $\mathrm{K}$ наиболее обсуждаемым и значимым в этом плане ограничениям относятся отсутствие у Аоноров стимулов Аля вылеления ОПР Аля алаптации [Buob S., Stephan G., 2013], слабые возможности Аля выделения ОПР на аАаптацию [Ayers J. M., Huq S., 2009], общее сомнение стран-Аоноров в эффективности OПP [Kalirajan K. et al., 2011]. В итоге многие страны вследствие физической нехватки финансовых средств не в состоянии обеспечить осуществление даже самых необходимых аАаптационных программ.

Ситуация усугубляется тем, что, как уже отмечалось ранее на примере изменения источников финансирования ААаптационного фонАа, в силу резко сократившегося интереса частных инвесторов к финансированию адаптационных программ эти мероприятия финансируются в основном за счет средств и добровольных взносов, осуществляемых правительственными организациями развитых стран мира (см. рис. 2). Анализ соотношения и структуры государственных и частных вложений в обеспечение основных направмений климатического финансирования, осуществленных в 2015-2016 гг., показал, что в настоящее время весь объем финансирования аАаптационных программ полностью складывается из государственных среАств при полном отсутствии частных источников финансирования. Последние в основном направляются на инвестиции в возобновляемые источники энергии (ВИЭ), в проекты по обеспечению энергоэффективности, а также в создание и развитие национальных систем “устойчивого" транспорта (рис. 4).

Рисунок 4

\section{Соотношение государственных и частных вложений в обеспечение основных направлений климатического финансирования, 2015-2016 гг., \% / The ratio of public and private investments in ensuring the main areas of climate finance, 2015-2016, \%}

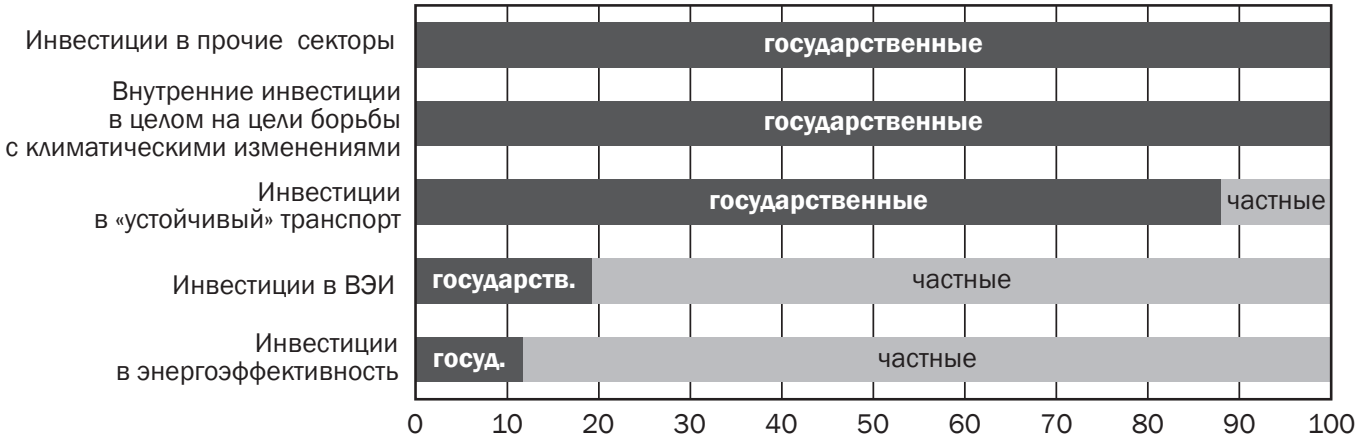

Источник: составлено автором по [OOH, 2019, с. 49] / Source: compiled by the author on [United Nations, 2019, p. 49].

В результате сложилась такая ситуация, что финансирование, выделяемое на адаптацию, составляет менее 10 \% от всего годового объема климатического финансирования (см. рис. 5). 


\section{Соотношение основных направлений климатического финансирования, 2015-2016 гг., \% / The ratio of the main directions of climate finance, 2015-2016, \%}

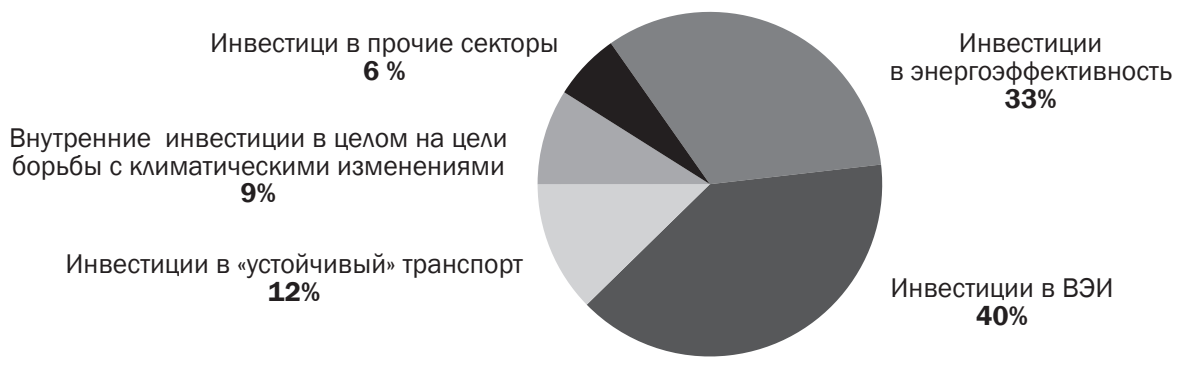

Источник: составлено автором по [OОH, 2019, с. 49] / Source: compiled by the author on [United Nations, 2019, p. 49].

В-четвертых, у многих стран существуют многочисленные недостатки и противоречия в самом механизме управления аАаптацией. Наиболее часто это проявляется на стадии перехода от планирования аАаптационных мероприятий к их реальному осуществлению [Mimura N. et al., 2014]. Институциональный разрыв межАу этапом планирования и этапом реализации планов становится серьезным препятствием Аля получения финансирования по программам аАаптации. При этом основными проблемами на третьем этапе чаще всего являются слабые институциональные составляющие самого механизма управлении процессом адаптации, а также отсутствие адекватной требованиям РКИК ООН и межАународных финансовых организаций системы управления адаптацией. Различные исследования доказали [Berrang-Ford L. et al., 2019; Dasgupta S., De Cian E., 2018; Williams D. S. et al., 2020], что страны с более эффективным управлением имеют больше шансов получить помощь по программам аАаптации от Аоноров, поскольку преАполагается, что при наличии эффективной системы управления финансовые среАства, выделенные на адаптацию, будут использоваться целенаправленно и более эффективно [Weiler F. et al., 2018]. Также зарубежные исследования доказали, что неэффективное управление может препятствовать способности страны реализовать цели и задачи адаптации, установленные в соответствии с уровнем уязвимости страны, а это приводит к отказу в финансировании адаптационных программ страны [Kettle N. P., Dow K., 2014; Basel B. et al., 2020].

В-пятых, в отАельных странах до сих пор сохраняется несоответствие национальной институциональной системы требованиям межАународных организаций и межАународных программ помощи. Важность соответствия национальных институтов международным требованиям борьбы с негативными климатическими изменениями и загрязнением окружающей среды, а также достижение связанных с ними целей устойчивого развития определяется тем, что целый комплекс финансовых вопросов и вопросов международного субсидирования тесно связан именно с состоянием системы институтов принимающих стран. На наднациональном уровне приток финансовых ресурсов и их распределение зависит от имеющихся международных соглашений и институциональных спонсоров (Аоноров), которые играют решающую роль в подАержке программ борьбы с изменением климата и Аостижения целей устойчивого развития [O'Neill B. C. et al., 2017]. Явственная необходимость наращивания потенциала институтов А^я проведения успешной адаптации была определена Аля развивающихся стран, особенно на уровне первичных образований - поселений, общин, Аеревень [Acemoglu D., Robinson J. A., 2013; Azhoni A., Goyal M. K., 2018; Basel B. et al., 2020]. 
Таким образом, в настоящее время существует ряд институциональных проблем в функционировании финансовых механизмов поддержки программ адаптации к кмиматическим изменениям, которые стали, по сути, серьезными институциональными барьерами в Аеятельности финансовых механизмов адаптации на всех этапах реализации РКИК ООН и целей устойчивого развития и которые пока не удалось преодолеть.

\section{ЗАКАЮЧЕНИЕ}

Исследование практики финансирования такого направления климатического регулирования, как финансовое обеспечение программ адаптации к негативным изменениям климата развивающихся стран, которые испытывают наибольшее воздействие ухудшения экологической ситуации на планете, осуществленное с помощью методов институционального анализа, показало, что заложенные в основу международных механизмов финансирования институты характеризуются внутренними и внешними противоречиями, обладают низкой способностью к реализации и низкой привлекательностью Аля инвесторов. Это в значительной степени тормозит успешную реализацию программ в Аанном направлении борьбы с климатическими изменениями [Lesnikowski A. et al., 2016]. В настоящее время финансирование, выделяемое на адаптацию, составляет всего лишь $10 \%$ от всего климатического финансирования.

Анализ нормативных документов ООН и Аругих международных организаций, а также зарубежной литературы по вопросам вклада институциональных механизмов в скорость и темпы продвижения различных стран по пути борьбы с негативными кмиматическими изменениями и загрязнением окружающей среды и Аостижением связанных с ними целей устойчивого развития показал, что в настоящее время в научных исследованиях и обзорах практик адаптации к климатическим изменениям в основном раскрываются вопросы, связанные с оценкой силы институциональных барьеров, уровня и направления ограничений, вызываемых слабой институциональной структурой отАельных стран и регионов [Eisenack K. et al., 2014]. В то же время реальных рекомендаций и шагов, позволяющих устранить или снизить остроту влияния этих барьеров, не принимается. Это обусловлено в значительной степени отсутствием единой методологической базы Аля разработки нормативных Аокументов в области аАаптации. В частности, необходимо Аать более четкое определение понятия климатического финансирования, а также его основных субъектов, привести в соответствие между собой нормы межАународного и национального законодательств разных стран, не допускающих многовариантности поАходов и неоднозначности толкования базовых терминов в сфере климатической аАаптации.

Проведение Аальнейших исследований в этой области должно быть сосредоточено на анализе и выявлении ключевых направлений и сфер институционального регулирования, позволяющих скоординировать усилия на Аостижении многосубъектного согласования поАХодОв и интересов Аля борьбы с климатическими изменениями и реализации на этой основе целей устойчивого развития.

\section{Список источников}

Аоклал о Целях в области устойчивого развития, 2019 год / Организация Объединенных Наций, 2019. 64 с. Казо Ж.-У., Кальехас Х. Ф., Иномата Т. Обзор мероприятий и ресурсов, относящихся к деятельности в связи с изменением климата, в организациях системы Организации Объединенных Наций / Объединенная инспекционная группа ООН. Женева, 2015. 82 с.

Acemoglu D., Robinson J. A. Why Nations Fail: The Origins of Power, Prosperity, and Poverty / Broadway Business, 2013.

Andrijevic M., Cuaresma J. C., Muttarak R. et al. Governance in socioeconomic pathways and its role for future adaptive capacity // Nature Sustainability. 2020. Vol. 3. Iss. 1. P. 35-41. URL: https://doi.org/10.1038/s41893019-0405-0. 
Azhoni A., Goyal M. K. Diagnosing climate change impacts and identifying adaptation strategies by involving key stakeholder organisations and farmers in Sikkim, India: Challenges and opportunities // Science of the Total Environment. 2018. Vol. 626. P. 468-477.

Ayers J. M., Huq S. Supporting Adaptation to Climate Change: What Role for Official Development Assistance? // Development Policy Review. 2009. Vol. 27. Iss. 6. P. 675-692.

Barr R., Fankhauser S., Hamilton K. Adaptation investments: a resource allocation framework // Mitigation and Adaptation Strategies for Global Change. 2010. Vol. 15 (8). P. 843-858.

Basel B., Goby G., Johnson J. Community-based adaptation to climate change in villages of Western Province, Solomon Islands // Marine Pollution Bulletin. 2020. Vol. 156. № 111266. URL: https://doi.org/10.1016/j. marpolbul.2020.111266.

Berrang-Ford L., Biesbroek R., Ford J. D. et al. Tracking global climate change adaptation among governments // Nature Climate Change. 2019. Vol. 9 (6). P. 440-449. URL: https://doi.org/10.1038/s41558-019-0490-0.

Berrang-Ford L., Ford J. D., Lesnikowski A. et al. What drives national adaptation? A global assessment // Climatic Change. 2014. Vol. 124 (1-2). P. 441-450. URL: https://doi.org/10.1007/s10584-014-1078-3.

Bouwer L. M., Aerts J. C. Financing climate change adaptation // Disasters. 2006. Vol. 30. Iss. 1. P. 49-63.

Brechin S. R., Espinoza M. I. A case for further refinement of the green climate fund's 50:50 ratio climate change mitigation and adaptation allocation framework: Toward a more targeted approach // Climatic Change. 2017. Vol. 142 (3-4). P. 311-320. URL: https://doi.org/10.1007/s10584-017-1938-8.

Buob S., Stephan G. On the incentive compatibility of funding adaptation // Climate Change Economics. 2013. Vol. 04. № 2. 1350005. URL: https://doi.org/10.1142/S201000781350005X.

Dasgupta S., De Cian E. The influence of institutions, governance, and public opinion on the environment: Synthesized findings from applied econometrics studies // Energy Research and Social Science. 2018. Vol. 43. P. 77-95. URL: https://doi.org/10.1016/j.erss.2018.05.023.

Eisenack K., Moser S. C., Hoffmann E. et al. Explaining and overcoming barriers to climate change adaptation // Nature Climate Change. 2014. Vol. 4 (10). P. 867-872. URL: https://doi.org/10.1038/nclimate2350.

Flåm K. H., Skjærseth J. B. Does adequate financing exist for adaptation in developing countries? // Climate Policy. 2009. Vol. 9. Iss. 1. P. 109-114.

Hinkel J., van Vuuren D. P., Nicholls R. J. et al. The effects of adaptation and mitigation on coastal flood impacts during the 21st century. An application of the DIVA and IMAGE models // Climatic Change. 2013. Vol. 117 (4). P. 783-794. https://doi.org/10.1007/s10584-012-0564-8.

Hof A. F., de Bruin K. C., Dellink R. B. et al. The effect of different mitigation strategies on international financing of adaptation // Environmental Science \& Policy. 2009. Vol. 12 (7). P. 832-843.

Hughes S. Principles, drivers, and policy tools for just climate change adaptation in legacy cities // Environmental Science \& Policy. 2020. Vol. 111. P. 35-41. URL: https://doi.org/10.1016/j.envsci.2020.05.007.

Jones R. N., Patwardhan A., Cohen S. J. et al. Foundations for decision making / Climate Change 2014: Impacts, Adaptation, and Vulnerability. Part A: Global and Sectoral Aspects. Contribution of Working Group II to the Fifth Assessment Report of the Intergovernmental Panel on Climate Change. Cambridge University Press, 2014. P. 195-228.

Kalirajan K., Singh K., Thangavelu S. et al. Climate Change and Poverty Reduction: Where Does Official Development Assistance Money Go? // ADBI Working Paper Series. No. 318. Asian Development Bank Institute, 2011. 43 p.

Kettle N. P., Dow K. Cross-level differences and similarities in coastal climate change adaptation planning // Environmental Science and Policy. 2014. Vol. 44. P. 279-290. URL: https://doi.org/10.1016/j.envsci.2014.08.013.

Klein R. J. T., Midgley G. F., Preston B. L. et al. Adaptation opportunities, constraints, and limits. In: Climate Change 2014: Impacts, Adaptation, and Vulnerability. Part A: Global and Sectoral Aspects. Contribution of Working Group II to the Fifth Assessment Report of the Intergovernmental Panel on Climate Change. Cambridge University Press, 2014. P. 899-943.

Lesnikowski A., Ford J., Biesbroek R. et al. National-level progress on adaptation // Nature Climate Change. 2016. Vol. 6 (3). P. 261-264. URL: https://doi.org/10.1038/nclimate2863.

Mace M. J., Verheyen R. Loss, Damage and Responsibility after COP 21: All Options Open for the Paris Agreement // Review of European, Comparative and International Environmental Law. 2016. Vol. 25. Iss. 2. P. 197-214. URL: https://doi.org/10.1111/reel.12172.

Mimura N., Pulwarty R. S., Duc D. M. et al. Adaptation planning and implementation / Climate Change 2014: Impacts, Adaptation, and Vulnerability. Part A: Global and Sectoral Aspects. Contribution of Working Group II to the Fifth Assessment Report of the Intergovernmental Panel on Climate Change. Cambridge University Press, 2014. P. 869-898.

Noble I. R., Huq S., Anokhin Y. A. et al. Adaptation needs and options / Climate Change 2014: Impacts, Adaptation, and Vulnerability. Part A: Global and Sectoral Aspects. Contribution of Working Group II to the Fifth Assessment Report of the Intergovernmental Panel on Climate Change. Cambridge University Press, 2014. P. 833-868.

O'Neill B. C., Kriegler E., Ebi K. L. et al. The roads ahead: Narratives for shared socioeconomic pathways describing world futures in the 21st century // Global Environmental Change. 2017. Vol. 42. P. 169-180. URL: https://doi. org/10.1016/j.gloenvcha.2015.01.004. 
Smit B., Burton I., Klein R. J. T. et al. The Science of Adaptation: A Framework for Assessment // Mitigation and Adaptation Strategies for Global Change. 1999. Vol. 4. P. 199-213.

Smith J. B., Vogel J. M., Cromwell J. E. An architecture for government action on adaptation to climate change. An editorial comment // Climatic Change. 2009. Vol. 95 (1-2). P. 53-61.

Weiler F., Klöck C., Dornan M. Vulnerability, good governance, or donor interests? The allocation of aid for climate change adaptation // World Development. 2018. Vol. 104. P. 65-77. URL: https://doi.org/10.1016/ j.worlddev.2017.11.001.

Williams D. S., Rosendo S., Sadasing O. et al. Identifying local governance capacity needs for implementing climate change adaptation in Mauritius // Climate Policy. 2020. Vol. 20 (5). P. 548-562. URL: https://doi.org/ 10.1080/14693062.2020.1745743.

Поступила в редакцию 22 июня 2020 г. Принята к публикации 19 августа 2020 г.

\section{References}

Acemoglu D., Robinson, J.A. (2013). Why Nations Fail: The Origins of Power, Prosperity, and Poverty. Broadway Business.

Andrijevic M., Cuaresma J.C., Muttarak R. et al. (2020). Governance in socioeconomic pathways and its role for future adaptive capacity. Nature Sustainability, Vol. 3, no. 1, pp. 35-41. Available at: https://doi.org/ 10.1038/s41893-019-0405-0.

Azhoni A., Goyal M.K. (2018). Diagnosing climate change impacts and identifying adaptation strategies by involving key stakeholder organisations and farmers in Sikkim, India: Challenges and opportunities. Science of the Total Environment, vol. 626, pp. 468-477.

Ayers J.M., Huq S. (2009). Supporting Adaptation to Climate Change: What Role for Official Development Assistance? Development Policy Review, vol. 27, iss. 6, pp. 675-692.

Barr R., Fankhauser S., Hamilton K. (2010). Adaptation investments: a resource allocation framework. Mitigation and Adaptation Strategies for Global Change, vol. 15, no. 8, pp. 843-858.

Basel B., Goby G., Johnson J. (2020). Community-based adaptation to climate change in villages of Western Province, Solomon Islands. Marine Pollution Bulletin, vol. 156, no. 111266. Available at: https://doi.org/10.1016/ j.marpolbul.2020.111266.

Berrang-Ford L., Biesbroek R., Ford J.D. et al. (2019). Tracking global climate change adaptation among governments. Nature Climate Change, vol. 9, no. 6, pp. 440-449. Available at: https://doi.org/10.1038/s41558019-0490-0.

Berrang-Ford L., Ford J.D., Lesnikowski A. et al. (2014). What drives national adaptation? A global assessment. Climatic Change, vol. 124, no. 1-2, pp. 441-450. Available at: https://doi.org/10.1007/s10584-014-1078-3.

Bouwer L.M., Aerts J.C. (2006). Financing climate change adaptation. Disasters, vol. 30, no. 1, pp. 49-63.

Brechin S.R., Espinoza M.I. (2017). A case for further refinement of the green climate fund's 50:50 ratio climate change mitigation and adaptation allocation framework: Toward a more targeted approach. Climatic Change, vol. 142, no. 3-4, pp. 311-320. Available at: https://doi.org/10.1007/s10584-017-1938-8.

Buob S., Stephan G. (2013). On the incentive compatibility of funding adaptation. Climate Change Economics, vol. 04, no. 2, 1350005. Available at: https://doi.org/10.1142/S201000781350005X.

Cazo J.-U., Callejas H.F., Inomata T. (2015). Overview of activities and resources related to climate change activities in United Nations system organizations, JIU/REP/2015/5. United Nations Joint Inspection Unit, Geneva, $82 \mathrm{p}$.

Dasgupta S., De Cian E. (2018). The influence of institutions, governance, and public opinion on the environment: Synthesized findings from applied econometrics studies. Energy Research and Social Science, vol. 43, pp. 77-95. Available at: https://doi.org/10.1016/j.erss.2018.05.023.

Eisenack K., Moser S.C., Hoffmann E., et al. (2014). Explaining and overcoming barriers to climate change adaptation. Nature Climate Change, vol. 4, no. 10, pp. 867-872. Available at: https://doi.org/10.1038/ nclimate2350.

Flåm K.H., Skjærseth J.B. (2009). Does adequate financing exist for adaptation in developing countries? Climate Policy, vol. 9, no. 1, pp. 109-114.

Hinkel J., van Vuuren D.P., Nicholls R.J. et al. (2013). The effects of adaptation and mitigation on coastal flood impacts during the 21st century. An application of the DIVA and IMAGE models. Climatic Change, vol. 117, no. 4, pp. 783-794. Available at: https://doi.org/10.1007/s10584-012-0564-8.

Hof A.F., de Bruin K.C., Dellink R.B. et al. (2009). The effect of different mitigation strategies on international financing of adaptation. Environmental Science \& Policy, vol. 12, no. 7, pp. 832-843.

Hughes S. (2020). Principles, drivers, and policy tools for just climate change adaptation in legacy cities. Environmental Science and Policy, vol. 111, pp. 35-41. Available at: https://doi.org/10.1016/j.envsci.2020.05.007. 
Jones R.N., Patwardhan A., Cohen S.J. et al. (2014). Foundations for decision making. In: Climate Change 2014: Impacts, Adaptation, and Vulnerability. Part A: Global and Sectoral Aspects. Contribution of Working Group II to the Fifth Assessment Report of the Intergovernmental Panel on Climate Change. Cambridge University Press, pp. 195-228.

Kalirajan K., Singh K., Thangavelu S. et al. (2011). Climate Change and Poverty Reduction: Where Does Official Development Assistance Money Go? ADBI Working Paper Series, no. 318. Asian Development Bank Institute. Tokyo, Japan. 43 p.

Kettle N.P., Dow K. (2014). Cross-level differences and similarities in coastal climate change adaptation planning. Environmental Science \& Policy, vol. 44, pp. 279-290. Available at: https://doi.org//10.1016/j.envsci. 2014.08.013.

Klein R.J.T., Midgley G.F., Preston B.L. et al. (2014). Adaptation opportunities, constraints, and limits. In: Climate Change 2014: Impacts, Adaptation, and Vulnerability. Part A: Global and Sectoral Aspects. Contribution of Working Group II to the Fifth Assessment Report of the Intergovernmental Panel on Climate Change. Cambridge University Press, pp. 899-943.

Lesnikowski A., Ford J., Biesbroek R. et al. (2016). National-level progress on adaptation. Nature Climate Change, vol. 6, no. 3, pp. 261-264. Available at: https://doi.org/10.1038/nclimate2863.

Mace M.J., Verheyen R. (2016). Loss, damage and responsibility after COP 21: All options open for the Paris agreement. Review of European, Comparative and International Environmental Law, vol. 25, no. 2, pp. $197-214$. Available at: https://doi.org/10.1111/reel.12172.

Mimura N., Pulwarty R.S., Duc D.M. et al. (2014). Adaptation planning and implementation. In: Climate Change 2014: Impacts, Adaptation, and Vulnerability. Part A: Global and Sectoral Aspects. Contribution of Working Group II to the Fifth Assessment Report of the Intergovernmental Panel on Climate Change. Cambridge University Press, pp. 869-898.

Noble I.R., Huq S., Anokhin Y.A. et al. (2014). Adaptation needs and options. In: Climate Change 2014: Impacts, Adaptation, and Vulnerability. Part A: Global and Sectoral Aspects. Contribution of Working Group II to the Fifth Assessment Report of the Intergovernmental Panel on Climate Change. Cambridge University Press, pp. 833-868.

O'Neill B.C., Kriegler E., Ebi K.L. et al. (2017). The roads ahead: Narratives for shared socioeconomic pathways describing world futures in the 21st century. Global Environmental Change, vol. 42, pp. 169-180. Available at: https://doi.org/10.1016/j.gloenvcha.2015.01.004.

Smit B., Burton I., Klein R.J.T., Wandel J. (1999). The science of adaptation: a framework for assessment. Mitigation and Adaptation Strategies for Global Change, vol. 4, pp. 199-213.

Smith J.B., Vogel J.M., Cromwell J.E. (2009). An architecture for government action on adaptation to climate change. An editorial comment. Climatic Change, vol. 95, no. 1-2, pp. 53-61.

United Nations (2019). Sustainable Development Goals Report 2019, 64 p.

Weiler F., Klöck C., Dornan M. (2018). Vulnerability, good governance, or donor interests? The allocation of aid for climate change adaptation. World Development, vol. 104, pp. 65-77. Available at: https://doi.org/10.1016/ j.worlddev.2017.11.001.

Williams D.S., Rosendo S., Sadasing O. et al. (2020). Identifying local governance capacity needs for implementing climate change adaptation in Mauritius. Climate Policy, vol. 20, no. 5, pp. 548-562. Available at: https://doi.org/ 10.1080/14693062.2020.1745743.

Received 22.06.2020

Accepted for publication 19.08.2020 


\title{
Климатическая политика Российской Федерации: МежАународное сотрУАничество и национальный подХоА
}

\author{
Игорь Алексеевич Яковлев, к. э. Н., руководитель Центра межАународных \\ финансов НИФИ Минфина России, г. Москва \\ E-mail: iyakovlev@nifi.ru, ORCID 0000-0002-6820-4689 \\ Аюдмила Сергеевна Кабир, А. э. н., профессор, главный научный сотрудник \\ Центра международных финансов НИФИ Минфина России, г. Москва \\ E-mail: Ikabir@nifi.ru, ORCID 0000-0002-0665-8992 \\ Светлана Игоревна Никулина, научный сотрудник Центра международных \\ финансов НИФИ Минфина России, г. Москва \\ E-mail: snikulina@nifi.ru, ORCID 0000-0002-1525-7648
}

\begin{abstract}
Аннотация
В статье представлен анализ к^ючевых положений климатической политики Российской Федерации и основных этапов ее становления. Актуальность темы исслеАования обусловлена необходимостью разработки эффективной национальной стратегии Аействий по снижению климатических рисков Аля устойчивого социально-экономического развития страны. Цель исслеАования заключается в формировании обоснованного преАставления о современном состоянии климатической политики Российской Федерации.

В статье проведен анализ межАународных подходов к формированию механизма, задействующего все государства в глобальном сотрудничестве по борьбе с изменением климата и адаптации к его послеАствиям, а также нормативных правовых документов Российской Федерации, регулирующих отношения в сфере вопросов борьбы с изменениями климата и адаптации к последствиям изменения климата. В результате проведенного исследования описан современный климатический режим ООН, сформировавшийся в итоге многолетнего межАународного сотрудничества. Проанамизирован поАход Российской ФеАерации к формированию климатической политики и систематизированы ключевые проблемы, влияющие на позицию страны в сфере разработки национальной климатической политики.

САеланы следующие выводы. Развитие климатической политики Российской Федерации осуществляется в русле глобальной концепции, однако ее ключевые вопросы еще комплексно не вписаны в национальную социально-экономическую политику. Наблюдаемый этап развития климатической политики Российской Федерации позволяет преАположить, что в ближайшее время процесс ее формирования Аолжен перейти на качественно новый уровень, а динамика процессов в области государственного регулирования вопросов борьбы с изменением климата и аАаптации к его послеАствиям АОлжна повыситься.
\end{abstract}

Ключевые слова: изменение климата, адаптация к изменению климата, международные соглашения, национальная политика, климатическая политика, Рамочная конвенция по изменению климата, Киотский протокол, Парижское соглашение

JEL: F64, 044, Q58 
Аля цитирования: Яковлев И. А., Кабир А. С., Никулина С. И. Климатическая политика Российской Федерации: международное сотрудничество и национальный подхоА // Финансовый журнал. 2020. T. 12. № 4. C. 26-36. DOI: 10.31107/2075-1990-2020-4-26-36.

DOI: 10.31107/2075-1990-2020-4-26-36

\title{
Climate Policy of the Russian Federation: International Cooperation and National Approach
}

\author{
Igor A. Yakovlev ${ }^{1}$
}

E-mail: iyakovlev@nifi.ru, ORCID 0000-0002-6820-4689

Lyudmila S. Kabir ${ }^{1}$

E-mail: Ikabir@nifi.ru, ORCID 0000-0002-0665-8992

Svetlana I. Nikulina ${ }^{1}$

E-mail: snikulina@nifi.ru, ORCID 0000-0002-1525-7648

${ }^{1}$ Financial Research Institute, Moscow 127006, Russian Federation

\begin{abstract}
The article gains an insight into the key provisions of Russia's climate policy and the main stages of its formation. The relevance of the research topic is determined by the need to develop an effective national strategy to reduce climate risks for Russia's sustainable social and economic development. The article is aimed at shaping a well-grounded understanding of the current state of the national climate policy. It describes the current climate regime of the United Nations, resulting from longstanding international cooperation. The article analyses Russia's approach to the formation of climate policy on the basis of the national legal framework to combat climate change and adapt to its consequences, and identifies the key problems affecting the formation of the national climate policy. As a result of the research the authors have come to the following conclusions. The climate policy of the Russian Federation is developing in accordance with the global concept. However, the key issues of climate policy have not yet been fully integrated into the national social and economic policy. The current stage in the development of Russian climate policy suggests that the process of its formation should move to a new quality level in the short run.
\end{abstract}

Keywords: climate change, climate change adaptation, international agreements, national policy, climate policy, Framework Convention on Climate Change, Kyoto Protocol, Paris Agreement

JEL: F64, 044, Q58

For citation: Yakovlev I.A., Kabir L.S., Nikulina S.I. Climate Policy of the Russian Federation: International Cooperation and National Approach. Financial Journal, 2020, vol. 12, no. 4, pp. 26-36 (In Russ.). DOI: 10.31107/2075-1990-2020-4-26-36.

\section{BВEAEHИE}

Согласно принятым мировым сообществом целям устойчивого развития кмиматические изменения являются частью совокупного риска Аля жизни и зАоровья ^юАей и роста экономики, поэтому решение проблемы кмиматических изменений признается оАним из условий минимизации этого риска. Сегодня мировым сообществом определены Ава пути решения этой проблемы. Во-первых, переход к модели низкоуглеродного развития, предусматривающей максимальное снижение выбросов парниковых газов (прежде всего углекислого газа), и, во-вторых, адаптация к последствиям изменения климата. ПреАполагается, что меры, принимаемые странами в рамках указанных Авух направлений, смогут компенсировать послеАствия климатических изменений, что позволит обеспечить устойчивое социально-экономическое развитие как отАельных стран, так и мира в целом. 
Климатическая повестка Аостаточно Аавно и активно обсуждается на международном уровне, что привело к формированию институциональной структуры, координирующей Аействия стран по борьбе с изменениями климата и их послеАствиями в глобальном масштабе. Ряд стран провозгласил климатическую политику национальным приоритетом, разработал стратегии социально-экономического развития, интегрируя в них проблемы изменения климата и адаптации к послеАствиям этих изменений, и приступил к их реализации.

Россия не относится к числу стран - лидеров глобального климатического Авижения, но в свое время активно подАержала этот процесс на глобальном уровне. Также в нашей стране Ао сих пор не сложилось однозначного мнения в отношении проблемы изменения климата и не выработан разделяемый всеми заинтересованными лицами поАХоА К интеграции глобальных решений в этой сфере в национальную повестку развития. В связи с этим изучение климатической политики нашей страны в контексте интеграции решений, Аостигнутых в результате межАународного сотрудничества по этому вопросу, в национальную политику представляет значительный интерес, поскольку позволит понять основные проблемы, влияющие на ее формирование, выявить этапы ее развития и выделить к^ючевые элементы ее организации.

\section{АИСКУССИОННЫЕ ВОПРОСЫ НАЦИОНААЬНОЙ КАИМАТИЧЕСКОЙ ПОАИТИКИ}

Сегодня можно констатировать, что вопросы изменения климата и адаптации к послеАствиям этого процесса прочно вошли в политическую повестку. В то же время на уровне отдельных стран еще не сложилось окончательного и четкого понимания того, какой минии поведения следует придерживаться и какие приоритеты Аолжны стать предпочтительными. Все это в полной мере относится и к Российской Федерации, климатическая политика которой еще формируется. Анализ научной Аискуссии по Аанному вопросу, развернувшейся среди российских исследователей, раскрывает ключевые проблемы, влияющие на позицию Российской Федерации относительно формирования национальной климатической политики.

Широкую Аискуссию вызывает вопрос целей национальной климатической политики [Русакова Ю. А., 2015; Тетушкин В. А., 2017; Макаров И. А., Степанов И. А., 2017] и ее Аетализации ${ }^{1}$. Отмечается, что ситуация в России аналогична ситуации, наблюдаемой в ряде Аругих стран, например в странах ЕС. Проблема нечеткости национальной климатической политики формируется не столько поА влиянием рентной компоненты национальной экономики и ее высокой энергоемкости, сколько поА влиянием различного сочетания множества экономических, а также внутри- и внешнеполитических факторов, которые кажАый раз складываются в новую картину [Кокорин А. О., 2016]. Именно это объясняет суть споров в отношении амбициозности (неамбициозности) целей климатической политики, различных ее компонент и сроков выполнения.

Еще оАним направлением Аискуссии является вопрос эффективности мер, принимаемых в рамках международных климатических соглашений [Вирт А. А., 2017]. Обращается внимание на прямую связь эффективности мер со скоростью и полнотой принятия национальных актов, а также с формируемой системой нормативных правовых актов (трудности имплементации). Российская специфика заключается в отсутствии еАиного акта, закладывающего основы национальной климатической политики в целом. При этом наблюдаются "немногочисленные федеральные законы (в основном о ратификации международных Аоговоров), в соответствии с которыми в последующем принимаются подзаконные акты"

${ }^{1}$ Аетализация климатической политики в мире и России // Энергетический бюметень. 2018. Вып. 67. URL: https://ac.gov.ru/archive/files/publication/a/20218.pdf. 
[Гарафова А. И., 2017, с. 158]. Немаловажным признается и фактор времени, согласно которому Аля нашей страны характерен большой временной лаг межАу принятием соглашения на международном уровне и ратификацией этого международного соглашения, а также изданием последующих нормативных актов.

ОтАельное направление Аискуссии формирует обсужАение вопроса влияния климатической политики на эффективность функционирования национальной экономики. В русле Аанного направления рассматриваются подходы к повышению эффективности существующей модели экономики [Пискулова Н. А. и Ар., 2013; Васильцов В. С., Яшалова Н. Н., 2018], когАа предполагается повышение ее инновационности поА влиянием реализации мер национальной климатической политики. Еще одна проблема, к которой привлекается особенное внимание в рамках этого направления, - повышение эффективности сектора энергетики. Поиск решений здесь осуществляется через оценку рисков перехода к низкоуглеродному развитию [Мастепанов А. М., 2017; Макаров И. А., Степанов И. А., 2018; Блиновская Я. Ю., Мазлова Е. А., 2019], что является одним из постулатов глобальной климатической политики.

Управление кииматическими рисками также выступает предметом Аискуссии. ОбсужАение этой проблемы идет по Авум направлениям. Первое направление разрабатывает проблематику управления климатическими рисками на всех уровнях хозяйствования в условиях повышения неопределенности и значимости климатических изменений [Васильцов В. С. и Ар., 2019]. Второе - преследует своей целью разработку прелложений, повышающих эффективность климатических инвестиционных проектов Аля российского бизнеса и уделяющих основное внимание государственной подАержке подобных инвестиционных проектов с целью снижения их рискованности Аля частного инвестора [Кузьминых Ю. В., 2020].

Перечисленными вопросами не исчерпывается сложность формирования национальной климатической повестки. Рассматриваемые в отдельности, они представляют размичные мнения в отношении того, приведет ми реализация Аействий, предусмотренных международными соглашениями по климату, к падению роста национальной экономики. Несмотря на то что сегодня уже доказано, что "экономический рост и решение климатических проблем - не антагонисты, надо лишь правильно расставить приоритеты" [Порфирьев Б. Н., 2019а, с. 27], проблема "правильной расстановки приоритетов" все еще не решена.

В то же время в настоящее время все большее распространение и обоснование помучает позиция, Аоказывающая бесперспективность борьбы с климатическими изменениями в формате низкоуглеродной парадигмы, а альтернатива представлена в форме "комплексного решения, предусматривающего смягчение проблемы изменений климата и их последствий Аля населения и экономики в контексте обеспечения в среАнесрочной перспективе приоритета социально-экономических целей устойчивого развития" [Порфирьев Б. Н., 20196, с. 12]. Это означает, что меры климатической политики не Аолжны становиться самоцелью, а должны быть вписаны в национальную социальноэкономическую политику, центральным элементом которой выступают приоритетные цели устойчивого развития, во-первых, превосходящие по значимости проблему снижения техногенных выбросов $\mathrm{CO}_{2}$, и, во-вторых, являющиеся источником ресурсов или условием Аля решения климатической проблемы. В качестве такого ресурса (источника) преАставляется экономический рост.

\section{СОВРЕМЕННЫЙ КАИМАТИЧЕСКИЙ РЕЖИМ ООН КАК ИТОГ МНОГОАЕТНЕГО МЕЖАУНАРОАНОГО СОТРУАНИЧЕСТВА}

Сотрудничество стран по вопросам борьбы с изменением климата и адаптации к послеАствиям его изменения имеет свою специфику, заключающуюся в том, что, несмотря на 
Аостаточно Алительную историю существования этой проблемы, Ао сих пор не созАана глобальная международная организация, а сотрудничество реализуется в формате модели "рамочное соглашение + протоколы", Аостигшей, по мнению экспертов, высокой степени структурной обособленности [Вирт А. А., 2017, с. 187]. МежАународный климатический режим ООН был сформирован Рамочной конвенцией ООН об изменении климата в 1992 г. $^{2}$ (Аалее - РКИК ООН), впослеАствии развит Киотским протоколом ${ }^{3}$ к РКИК ООН (Аалее - Киотский протокол), на смену которому в 2015 г. пришло Парижское соглашение $^{4}$. Правилами последнего страны - стороны Соглашения Аолжны руководствоваться начиная с 2020 г.

Суть формируемого кмиматического режима заключается в поиске путей противоАействия глобальному потеплению планеты, которое приводит к катастрофическим изменениям климата. Научно аргументирован заметный вклаА техногенного фактора в глобальное изменение климата. В связи с этим предложены меры, сочетающие смягчение техногенного воздействия на климатообразующие факторы и условия (снижение выбросов парниковых газов, в первую очередь оксида углерода, что предполагается Аостичь за счет перехода к низкоуглеродной модели развития), и адаптацию населения и экономик стран к изменениям климата.

ЗАесь следует отметить, что Ао послеАнего времени вопросы аАаптации к послеАствиям изменения климата находились на вторых по значимости ролях по сравнению с заАачей перехода к низкоуглеродной экономике. С принятием Парижского соглашения обозначилось смещение тенденции в "климатическом мейнстриме" от "низкоуглеродного развития" в сторону аАаптации. Это было обусловлено низкой эффективностью существующей стратегии реализации климатической политики и попытками переосмыслить роль низкоуглеродного пути развития как ключевого Арайвера.

Не останавливаясь на хронологии развития процесса в контексте формирования глобального механизма финансирования национальных программ по борьбе с изменением климата и адаптации к послеАствиям изменения климата, которая описана в Аругом исследовании [Яковлев И. А., Кабир А. С., 2019, с. 45-47], Аадим характеристику его текущего состояния, определяемого Парижским соглашением 2015 г.

Во-первых, Парижское соглашение изменяет роль стран в обязательствах по снижению объемов выбросов парниковых газов. Было Аостигнуто понимание, что Аанные обязательства должны быть применимы ко всем странам - сторонам Соглашения, а не только к развитым странам. А дифференцированный подхоА означает, что страны, включая развивающиеся, могут сами определять свой вклаА в решение общей проблемы, исходя из планов социально-экономического развития страны и переживаемых трудностей. Ранее он трактовался как возможность развивающихся стран не предпринимать никаких Аействий по смягчению последствий изменения климата.

Во-вторых, Парижское соглашение изменяет характер обязательств стран в рамках борьбы с изменением климата и адаптации к послеАствиям его изменения. Провозглашенный принцип "снизу вверх" превратил обязательства, существующие Аля отАельных, преимущественно развитых, стран, в односторонние добровольные вклады Аля всех государств, определяемые на национальном уровне (Nationally Determined Contributions NDCs). Этот принцип отвечал как требованиям отдельных развитых стран, которые не

\footnotetext{
2 Рамочная конвенция ООН об изменении климата. URL: https://www.un.org/ru/documents/decl_conv/ conventions/climate_framework_conv.shtml.

з Киотский протокол к Рамочной конвенции ООН об изменении климата. Принят 11 декабря 1997 г. URL: https://www.un.org/ru/documents/decl_conv/conventions/kyoto.shtml.

4 Парижское соглашение. Принято 12 декабря 2015 г. URL: https://unfccc.int/files/meetings/paris_ nov_2015/application/pdf/paris_agreement_russian_.pdf.
} 
готовы были принять на себя обязательства по сокращению выбросов, определяемых относительно уровня 1990 г., так и потребностям развивающихся стран, вклаА которых "зачастую закреплялся в виде инициатив, ограниченных отАельными секторами экономики" [Вирт А. А., 2017, с. 198].

В-третьих, закрепляется активная и лидирующая роль развитых стран в установлении более амбициозных целевых показателей по снижению уровня выбросов, а также в оказании финансовой помощи и подАержки в области переАачи технологий и укрепления потенциала развивающихся стран.

Таким образом был разработан механизм, позволяющий задействовать все государства в глобальном сотрудничестве по борьбе с изменением климата и адаптации к его последствиям. Задачей этого механизма признается достижение "сбалансированности межАу антропогенными выбросами из источников и абсорбцией поглотителями парниковых газов во второй половине этого века" (ст. 4 Соглашения), т. е. обеспечение нулевого показателя уровня выбросов парниковых газов, когАа все выбросы парниковых газов полностью сбалансированы поглощающими механизмами.

\section{НАЦИОНААЬНЫЙ ПОАХОА К ФОРМИРОВАНИЮ КАИМАТИЧЕСКОЙ ПОАИТИКИ}

Формирование национальной кмиматической политики России началось, по сути, с момента ратификации РКИК ООН. Россия также являлась стороной Киотского протокола и с 2019 г. стала полноценным участником Парижского соглашения. Несмотря на это, Россия на настоящий момент времени еще не сформировала свой определяемый на национальном уровне вклаА (NDC). На момент написания статьи 186 стран мира уже преАоставили свои первые определяемые на национальном уровне вклады и четыре страны - вторые 5 .

В климатической политике России можно выделить Ава направления. Хронологически первым стало формироваться направление, связанное с регулированием выбросов парниковых газов, которое в своем развитии прошло несколько этапов. В период после поАписания РКИК ООН Ао поАписания Киотского протокола (1994-2005 гг.) вопросы сохранения климата отАельно не регулировались. Но в это время были приняты Ава федеральных закона: "Об охране атмосферного воздуха"6 и "Об охране окружающей среды" которые не прямо, но косвенно влияют на формирование в России условий по снижению антропогенного влияния на климат, поскольку направлены на регулирование выбросов, загрязняющих окружающую среду и атмосферный воздух.

После подписания Киотского протокола, во время участия в первом периоде обязательств (2008-2012 гг.) $)^{8}$ в стране была предпринята попытка выстроить систему учета и аАминистрирования углеродных еАиниц Аля участия в межАународной торговле ими, которая устанавливалась Киотским протоколом. Также этот периоА примечателен стартом национальной политики в области повышения энергоэффективности, что было обусловлено необходимостью разработки программ сокращения выбросов парниковых газов Аля обеспечения участия страны в системе торговли углеродными еАиницами.

Особенностью этого этапа также можно считать принятие Климатической доктрины Российской ФеАерации ${ }^{9}$ и комплексного плана по ее реализации ${ }^{10}$. ЗаАачей этих Аокументов

5 NDC Registry (interim). URL: https://www4.unfccc.int/sites/NDCStaging/Pages/All.aspx.

6 Федеральный закон от 04.05.1999 № 96-Ф3 "Об охране атмосферного воздуха".

7 Федеральный закон от 10.01.2002 № 7-Ф3 "Об охране окружающей среды”.

8 Первый период - 2008-2012 гг., второй период - 2013-2020 гг. Россия во втором периоде не участвовала в связи с тем, что не смогла получить значительных коммерческих выгод от участия в первом периоде.

9 Распоряжение Президента Российской Федерации от 17.12.2009 № 861-рп “О Климатической Аоктрине Российской Федерации".

10 Распоряжение Правительства Российской Федерации от 25.04.2011 № 730-р "Об утвержАении комплексного плана реализации Кииматической доктрины Российской Федерации на период Ао 2020 года". 
являлось создание рамок Аальнейшего развития национальной климатической политики, поэтому в плане Аействий фиксируются организационные мероприятия, необходимые Аля создания системы учета выбросов парниковых газов. С этой целью разрабатывается план Аействий, направленных на:

1) усиление научной обоснованности политики в области климата и развитие инструментов прогнозирования и мониторинга в этой сфере; повышение информированности и компетенции гражАан, включая обеспечение доступа общественности к информации по вопросам изменения климата и разработку учебных программ и программ подготовки и повышения квалификации калров;

2) разработку методик расчета рисков и оценки последствий климатических изменений, систем критериев, параметров и условий безопасности, оценки уязвимости территорий, населения, зАаний, сооружений, инфраструктуры, секторов экономики, природных объектов к изменениям климата, а также разработку подходов к минимизации выявляемых рисков;

3) разработку межотраслевых и секторальных стратегий ограничения выбросов парниковых газов, ограничения выбросов парниковых газов за счет повышения энергоэффективности оборудования, оптимизации ведения работ в лесном секторе и сельском хозяйстве.

Таким образом, были заложены основы формирования системы скоординированных Аействий, направленных на обеспечение безопасного и устойчивого развития Российской Федерации в условиях изменяющегося климата.

Период ПоАготовки к ПоАписанию Парижского соглашения и Ао настоящего времени (2013-2020 гг.) ознаменовался принятием целого ряда Аокументов, разработка которых была определена комплексным планом по реализации Климатической доктрины Российской Фелерации. Были приняты документы концептуального характера, например Концепция формирования системы мониторинга, отчетности и верификации выбросов парниковых газов ${ }^{11}$, а также целый блок нормативных правовых актов, обеспечивающих подготовку и предоставление организациями сведений (отчетов) об объеме выбросов парниковых газов, а также проверку и регистрацию предоставленных сведений. В результате были созданы организационные основы системы учета выбросов парниковых газов, которая необходима Аля реалистичной оценки ситуации в Аанной сфере, а также разработки планов государственного регулирования деятельности компаний, связанной с выбросами парниковых газов.

Направление, связанное с адаптацией к последствиям изменения киимата, в национальной климатической политике стало формироваться совсем неАавно, после ратификации Россией в 2019 г. Парижского соглашения, и представлено пока одним регумирующим Аокументом - Национальным планом мероприятий первого этапа адаптации к изменениям климата на периоА Ао 2022 г. ${ }^{12}$ Констатируя важность Аля России проблемы аАаптации к изменениям климата, этот Аокумент не преАлагает конкретных мер по адаптации экономики и населения нашей страны к изменению климата, но задает рамки организации процесса, обеспечивающего разработку конкретных мер адаптации, их принятие и последовательную реализацию.

Согласно этому плану в IV квартале 2020 г. Аолжны быть разработаны методические рекоменАации по формированию отраслевых, региональных и корпоративных планов

\footnotetext{
${ }^{11}$ Распоряжение Правительства Российской Федерации от 22.04.2015 № 716-р "Об утверждении Концепции формирования системы мониторинга, отчетности и проверки объема выбросов парниковых газов в Российской Федерации".

12 Распоряжение Правительства Российской Федерации от 25.12.2019 № 3183-р "Об утверждении национального плана мероприятий первого этапа аАаптации к изменениям климата на период Ао 2022 г.".
} 
адаптации к изменениям климата (мероприятие № 9). Сами отраслевые планы аАаптации к изменениям климата Аолжны быть разработаны и утверждены в III квартале 2021 г. в разрезе следующих секторов: транспорт, топливно-энергетический комплекс, строительство и жилищно-коммунальное хозяйство, агропромышленный комплекс и рыболовство, природопользование, зАравоохранение, санитарно-эпидемиологическое благополучие населения, промышленный комплекс, техническое регулирование, внешняя и внутренняя торговля, гражданская оборона, защита населения и территорий от чрезвычайных ситуаций природного и техногенного характера (мероприятия № 18-24, 26). Отдельно выделяется подготовка планов адаптации Аля Арктической зоны Российской Фелерации (III квартал 2021 г., мероприятие № 25). Остальные регионы России Аолжны разработать и утвердить планы аАаптации к изменениям климата в IV квартале 2022 г. (мероприятие № 29).

Подготовка отраслевых и региональных планов адаптации к изменениям климата вызывает необходимость актуализации отраслевых документов стратегического планирования (предусмотрено в те же сроки, что и разработка секторальных планов) и корректировку документов стратегического планирования субъектов Российской Федерации (запланирован годичный временной маг межАу подготовкой преАложений по корректировке региональных стратегий и разработкой региональных планов адаптации).

Предполагается, что эффективный старт и реализацию хозяйствующими субъектами запланированных мер адаптации Аолжны обеспечить заблаговременно разработанные Минэкономразвития России, Минфином России и Банком России экономические и финансовые инструменты, а также механизмы страхования, распределяющие финансовую ответственность между частным сектором и государством, подготовка которых запланирована на III кварта^ 2021 г.

Таким образом, мероприятия по аАаптации к изменениям климата начнут реализовываться в Российской Федерации фактически только с 2023 г., в то время как мероприятия по снижению выбросов парниковых газов постепенно проникают в хозяйственную Аеятельность.

Невысокая интенсивность российской кмиматической политики в рамках обоих рассмотренных направлений объясняется ключевыми проблемами, описанными выше. И хотя климатическому фактору только преАстоит войти в повсеАневную практику учета рисков хозяйственной деятельности российских компаний, а нормативно-правовая база регулирования еще формируется, тем не менее подвижка в этом процессе уже началась. Сразу же следует отметить, что смещение в стратегическом планировании в силу понятных причин пока охватывает только вопросы, формулируемые в рамках первого направления, - снижение выбросов парниковых газов. Впервые они прозвучали в Прогнозе социально-экономического развития Российской Федерации на 2012 г. и плановый периол 2013-2014 гг. в контексте разработки рыночных механизмов регулирования выбросов парниковых газов. В формате разработки мер государственного регулирования выбросов парниковых газов этот вопрос сформулирован в ныне действующих отраслевых стратегиях, таких как Транспортная стратегия ${ }^{13}$, Стратегия развития месного комплекса Российской Фелерации до 2030 r. $^{14}$, а также Стратегия экологической безопасности Российской Федерации на периол до 2025 г..15

\footnotetext{
${ }^{13}$ Распоряжение Правительства Российской Федерации от 22.11.2008 № 1734-р “О Транспортной стратегии Российской Федерации".

14 Распоряжение Правительства Российской Федерации от 20.09.2018 № 1989-р "Об утверждении Стратегии развития лесного комплекса Российской Федерации до 2030 года".

${ }_{15}$ Распоряжение Правительства Российской Федерации от 29.05.2019 № 1124-р “Об утверждении плана мероприятий по реализации Стратегии экологической безопасности Российской Федерации на период Ао 2025 года".
} 
В июне текущего года были утверждены Сводная стратегия развития обрабатывающей промышленности Российской Федерации Ао 2024 г. и на период Ао 2035 г. $^{16}$, Энергетическая стратегия Российской Федерации на период Ао 2035 г. ${ }^{17}$, а также Программа развития угольной промышленности России на периоА Ао 2035 г. ${ }^{18}$, в которых обращается внимание на необходимость учета процессов в рамках глобальных соглашений по климату, выводящих страны на путь формирования долгосрочных стратегий развития с низким уровнем выбросов парниковых газов и рисков Аля развития отраслей.

Таким образом, вопросы климатической политики Российской Федерации еще комплексно не вписаны в национальную социально-экономическую политику, а проходят период осмысления, интерпретации и формулирования, подборки решений, соответствующих национальным особенностям развития. Формирование в национальной климатической политике нового направления - адаптация к изменениям климата - Аолжно стимулировать внимание и к ставшему уже традиционным направлению по регулированию выбросов парниковых газов. Также свою роль Аолжна сыграть и необходимость разработки Россией определяемого на национальном уровне вклада (NDC). Все эти факторы вместе Аолжны в итоге придать более конкретные формы национальной климатической политике и больший Аинамизм процессу ее формирования.

\section{ЗАКАЮЧЕНИЕ}

Изложенные выше суждения относительно проблем формирования национальной климатической политики, основных направлений ее развития и этапов приводят к следующим выводам:

1. Климатическая политика России формируется в сложной среде, Аля которой характерна разновекторная Аискуссия, охватывающая широкий спектр проблемных вопросов. Тем не менее основной проблемой дискуссии является оценка влияния мер климатической политики, принимаемых в соответствии с межАународными решениями, на рост национальной экономики. Именно признание угроз росту национальной экономики вслеАствие реализации климатической политики выступает главным сАерживающим фактором ее формирования, равно как и отсутствие сформулированных на национальном уровне приоритетов национальной климатической политики, позволяющих обеспечить Аостижение социально-экономических целей устойчивого развития, а не противоречащих им.

2. Принятие Парижского соглашения привело к усилению роли такого направления климатической политики, как адаптация к последствиям изменения климата, которое ранее находилось в тени проблематики построения модели низкоуглеродного развития. Кроме того, Парижское соглашение представило механизм, позволяющий задействовать все государства в глобальном сотрудничестве по борьбе с изменением климата и аАаптации к его послеАствиям.

3. Анализ формирующейся нормативной правовой базы национальной климатической политики указывает на то, что Россия в целом согласна с общим вектором низкоуглеродного развития, но не рассматривает его как единственный и не стремится его реализовать в кратчайшие сроки. Поэтому интеграция в нормативную правовую базу блока вопросов аАаптации к последствиям изменения климата, обозначенная в конце

\footnotetext{
16 Распоряжение Правительства Российской Федерации от 06.06.2020 № 1512-р “Об утвержАении Сводной стратегии развития обрабатывающей промышленности Российской Федерации до 2024 года и на периоА АО 2035 года".

${ }^{17}$ Распоряжение Правительства Российской Федерации от 09.06.2020 № 1523-р "Об утвержАении Энергетической стратегии Российской Федерации на период Ао 2035 года".

18 Распоряжение Правительства Российской Федерации от 13.06.2020 № 1582-р “Об утвержАении Программы развития угольной промышленности России на период до 2035 года".
} 
2019 г., Аолжна изменить вектор национальной климатической политики и придать ей больший Аинамизм.

В целом изменения в государственном стратегическом планировании, которые преАполагаются в рамках реализации Национального плана мероприятий первого этапа аАаптации к изменениям климата на периол Ао 2022 г., могут привести к существенному пересмотру национальной климатической политики и формированию ее приоритетов, не противоречащих целям социально-экономического устойчивого развития, что отсутствует в настоящее время. В этом случае можно ожидать формирования новых Арайверов роста национальной экономики.

\section{Список источников}

Блиновская Я. Ю., Мазлова Е. А. Основные тренды климатической политики в сфере Аобычи и переработки угля // Успехи современного естествознания. 2019. № 2. С. 86-93.

Васильцов В. С., Яшалова Н. Н. Климатическая политика в инновационной экономике: национальный и международный аспекты // Ars Administrandi (Искусство управления). 2018. T. 10. № 1. С. 38-63. URL: https:// doi.org/10.17072/2218-9173-2018-1-38-63.

Васильцов В. С., Яшалова Н. Н., Яковлева Е. Н. Модель организационно-экономического механизма управления климатическими рисками в условиях "зеленой" инновационно-ориентированной экономики // Вестник УАмуртского университета. 2019. Т. 29. Вып. 6. С. 730-735. URL: https://doi.org/10.35634/2412-9593-201929-6-730-735.

Вирт А. А. Парижское соглашение: новый компонент климатического режима ООН // Вестник межАунароАных организаций. 2017. Т. 12. № 4. С. 185-214. URL: https://doi.org/10.17323/1996-7845-2017-04-185.

Гарафова А. И. Особенности национально-правовой имплементации международных климатических соглашений: сравнительно-правовой анализ российского и японского законодательства // Вестник экономики, права и социологии. 2017. № 4. С. 154-158.

Кокорин А. О. Новые факторы и этапы глобальной и российской климатической политики // Экономическая политика. 2016. T. 11. № 1. С. 157-176. URL: https://doi.org/10.18288/1994-5124-2016-1-10.

Кузьминых Ю. В. Проблемы финансирования климатических проектов в Российской Федерации в современных условиях // Ученые записки Санкт-Петербургского имени В. Б. Бобкова филиала Российской таможенной акалемии. 2020. № 1 (73). С. 67-72.

Макаров И. А., Степанов И. А. Парижское соглашение по климату: влияние на мировую энергетику и вызовы Аля России // Актуальные проблемы Европы. 2018. № 1. С. 77-100.

Макаров И. А., Степанов И. А. Углеродное регулирование: варианты и вызовы Аля России // Вестник Московского университета. Серия 6: Экономика. 2017. № 6. С. 3-22.

Мастепанов А. М. Климатическая политика в Аолгосрочных прогнозах развития мировой энергетики // Энергетическая политика. 2017. № 4. С. 10-25.

Пискулова Н. А., Костюнина Г. М., Абрамова А. В. Климатическая политика основных торговых партнеров России и ее влияние на экспорт ряда российских регионов. М.: Всемирный фонА Аикой природы (WWF), 2013. 223 c. URL: https://wwf.ru/resources/publications/booklets/klimaticheskaya-politika-osnovnykh-torgovykhpartnerov-rossii-i-ee-vliyanie-na-eksport-ryada-rossiys/.

Порфирьев Б. Н. Климатический фактор развития российской экономики в среднесрочной перспективе: императивы и эффективность аАаптации / Сб. пленарных Аокладов V Санкт-Петербургского международного экономического конгресса (СПЭК-2019) // Экономическое возрожАение России. 2019. № 2 (60). С. 24-28.

Порфирьев Б. Н. Парадигма низкоуглеродного развития и стратегия снижения рисков климатических изменений Аля экономики // Проблемы прогнозирования. 2019. № 2. С. 3-13.

Русакова Ю. А. Климатическая политика Российской Федерации и решение проблем изменения глобального климата // Вестник МГИМО-Университета. 2015. № 1 (40). С. 66-72.

Тетушкин В. А. Анализ тренАов климатической политики как элемента экономической безопасности Российской Федерации: межАународный аспект // Региональная экономика: теория и практика. 2017. Т. 15. № 6 (441). C. 1173-1186. URL: https://doi.org/10.24891/re.15.6.1173.

Яковлев И. А., Кабир А. С. Климатические финансы в контексте устойчивого развития // Экономика. Налоги. Право. 2019. Т. 12. № 5. С. 44-51. URL: https://doi.org/10.26794/1999-849X-2019-12-5-44-51.

Поступила в редакцию 10 июля 2020 г. Принята к публикации 19 августа 2020 r. 


\section{References}

Blinovskaya Ya.Yu., Mazlova E.A. (2019). Climatic Policy Main Trends in the Production and Processing of Coal. Uspekhi sovremennogo estestvoznaniya - Advances in Current Natural Sciences, no. 2, pp. 86-93 (In Russ.).

Garafova D.I. (2017). Characteristics of Legal Implementation of International Climate Agreements: a Comparative Legal Analysis of Russian and Japanese Legislation. Vestnik ekonomiki, prava i sotsiologii - The Review of Economy, the Law and Sociology, no. 4, pp. 154-158 (In Russ.).

Kokorin A.O. (2016). New Factors and Stages of the Global and Russian Climate Policy. Ekonomicheskaya politika - Economic Policy, vol. 11, no. 1, pp. 157-176 (In Russ.). Available at: https://doi.org/10.18288/1994-51242016-1-10.

Kuzminykh Yu.V. (2020). Challenges in Financing Climate Projects in the Russian Federation in the Current Context. Uchenye zapiski Sankt-Peterburgskogo imeni V.B. Bobkova filiala Rossiiskoi tamozhennoi akademii Scholarly Notes of the Saint Petersburg Branch of the Russian Customs Academy named after V.B. Bobkov, no. 1 (73), pp. 67-72 (In Russ.).

Makarov I.A., Stepanov I.A. (2018). Paris Agreement on Climate Change: its Impact on World Energy Sector and New Challenges for Russia. Aktual'nye problemy Evropy - Current Problems of Europe, iss. 1, pp. 77-100 (In Russ.).

Makarov I.A., Stepanov I.A. (2017). Carbon Regulation: Options and Challenges for Russia. Vestnik Moskovskogo universiteta. Seriya 6: Ekonomika - Moscow University Economics Bulletin, no. 6, pp. 3-22 (In Russ.).

Mastepanov A.M. (2017). Climate Policy in Long-Term Forecasts of World Energy Development. Energeticheskaya politika - Energy Policy, no. 4, pp. 10-25 (In Russ.).

Piskulova N.A., Kostyunina G.M., Abramova A.V. (2013). Climate Policy of the Main Russia's Trade Partners and its Impact on the Exports of Some Russian Regions. Moscow: Vsemirnyi fond dikoi prirody (World Wildlife Fund), 223 p. (In Russ.). Available at: https://wwf.ru/resources/publications/booklets/klimaticheskaya-politika-osnovnykhtorgovykh-partnerov-rossii-i-ee-vliyanie-na-eksport-ryada-rossiys/.

Porfiryev B.N. (2019). Climate Factor in Medium-Term Development Prospects of the Russian Economy: Adjustment Imperatives and Efficiency. Collection of plenary reports of the St. Petersburg International Economic Congress "Foresight "Russia": Technological, Economic and Human Prospects". Ekonomicheskoe vozrozhdenie Rossii - Economic Revival of Russia, no. 2 (60), pp. 24-28 (In Russ.).

Porfiriev B.N. (2019). The Low-Carbon Development Paradigm and Climate Change Risk Reduction Strategy for the Economy. Problemy prognozirovaniya - Studies on Russian Economic Development, vol. 30, no. 2, pp. 111-118. Available at: https://doi.org/10.1134/S1075700719020163

Rusakova Yu.A. (2015). Climate Policy of the Russian Federation and the Problem of Global Climate Change. Vestnik MGIMO Universiteta - MGIMO Review of International Relations, no. 1 (40), pp. 66-72 (In Russ.).

Tetushkin V.A. (2017). Analysis of Trends in Climate Policy as Part of the Economic Security of the Russian Federation: the International Dimension. Regional'naya ekonomika: teoriya i praktika - Regional Economics: Theory and Practice, vol. 15, iss. 6 (441), pp. 1173-1186 (In Russ.). Available at: https://doi.org/10.24891/re.15.6.1173.

Vasil'tsov V.S., Yashalova N.N. (2018). Climatic Policy in the Innovation Economy: National and International Aspects. Ars Administrandi, vol. 10, no. 1, pp. 38-63 (In Russ.). Available at: https://doi.org/10.17072/2218-91732018-1-38-63.

Vasil'tsov V.S., Yashalova N.N., Yakovleva E.N. (2019). A Model of Organizational-Economic Mechanism for Managing Climate Risks in Conditions of Green Innovation-Oriented Economy. Vestnik Udmurtskogo universiteta Bulletin of Udmurt University, vol. 29, iss. 6, pp. 730-735 (In Russ.). Available at: https://doi.org/10.35634/24129593-2019-29-6-730-735.

Wirth D.A. (2017). The Paris Agreement as a New Component of the UN Climate Regime. Vestnik mezhdunarodnykh organizatsii - International Organisations Research Journal, vol. 12, no. 4, pp. 185-214. Available at: https:// doi.org/10.17323/1996-7845-2017-04-185.

Yakovlev I.A., Kabir L.S. (2019). Climate Finance in the Context of Sustainable Development. Ekonomika. Nalogi. Pravo - Economics, Taxes \& Law, vol. 12, no. 5, pp. 44-51 (In Russ.). Available at: https://doi.org/10.26794/1999849X-2019-12-5-44-51.

Received 10.07.2020

Accepted for publication 19.08.2020 


\title{
Роль государства в решении проблем развития "зеленого" финансирования
}

\begin{abstract}
Елена Петровна Федорова, к. э. Н., Аоцент кафедры экономической теории Астраханского государственного университета, г. Астрахань E-mail: lenafedorova@mail.ru
\end{abstract}

\begin{abstract}
Аннотация
Проблемы, связанные с развитием "зеленого" финансирования, существуют во всех странах мира. Эти проблемы особенно актуальны в развивающихся странах, чей экономический рост зависит от Аобычи топливных углеродных ископаемых. С целью исследования истории проблемы и выявления көючевых причин, сАерживающих развитие "зеленого" финансирования, в статье проводится системный обзор литературы, применяется системный аналитический поАХоА к исслеАОванию "зеленых" финансов, анализируется понятийная база, мировой опыт в решении проблем "зеленого" финансирования и проводится статистический анализ данных с сайтов международных организаций и финансовых институтов.

В статье рассмотрены проблемы, уникальные Аля "зеленого" финансирования: разногласия в трактовке понятия "зеленые" финансы и "зеленые" секторы экономики, трудности с оценкой внешнего эффекта от "зеленого" финансирования, институциональные причины, сАерживающие его развитие, информационная асимметрия, трудности с оценкой кредитных и рыночных рисков. Рассмотрены нововведения в финансовом секторе, характерные Аля Аолгосрочных инвестиций, такие как "зеленые" облигации, ценные бумаги, обеспеченные активами, доходные компании. В результате слелан вывоА, что Аля решения проблем "зеленого" финансирования необходим союз государства, межАународных организаций и фирм. Причем ведущая роль в этом союзе принаАлежит государству, которое Аолжно координировать, стимулировать и контролировать Аеятельность в области "зеленых" финансов.
\end{abstract}

Ключевые слова: устойчивое развитие, экономический рост, “зеленая" экономика, "Коричневая" экономика, "зеленые» финансы, «зеленые» инвестиции, «зеленые» облигации

JEL: 044, Q32

Аия цитирования: Федорова Е. П. Роль государства в решении проблем развития "зеленого" финансирования // Финансовый журнал. 2020. T. 12. № 4. C. 37-51. DOI: 10.31107/2075-19902020-4-37-51.

DOI: 10.31107/2075-1990-2020-4-37-51

\section{Role of the State in the Resolution of Green Finance Development Issues}

Elena P. Fedorova ${ }^{1}$

E-mail: lenafedorova@mail.ru

${ }^{1}$ Astrakhan State University, Astrakhan 414056, Russian Federation

\section{Abstract}

Problems related to green finance exist in all the countries of the world. Those problems are especially acute in the developing countries, whose economic growth depends on recovery of hydrocarbon fossil fuels. To research the history of issues related to green finance and identify the key reasons hampering 
its development, this article presents a systematic literature review; it applies a systematic analytical approach to researching green finance. The paper considers the key notions and the world expertise gained in the resolution of problems related to green finance; it also presents a statistical analysis of data provided by websites of international institutions and financial organizations.

This article analyzes a number of problems that are unique for green finance: disagreement in interpreting the concepts of "green finance" and "green economy sectors"; difficulties related to assessment and evaluation of the external effect exerted by green finance; institutional reasons hampering the development of green finance; information asymmetry; and problems related to estimation of credit and market risks. The paper considers innovations in the financial sector that are typical for long-term investment, such as green bonds, asset-backed security, and yield cos. As a result, the article concludes that cooperation between the government, international institutions, and business companies is necessary to resolve the issues of green finance. The government ought to play the key role in that cooperation - it must inform, coordinate, stimulate, and control activities related to green finance.

Keywords: sustainable development, economic growth, green economy, green finance, green investment, green bond

JEL: 044, Q32

For citation: Fedorova E.P. Role of the State in the Resolution of Green Finance Development Issues. Financial Journal, 2020, vol. 12, no. 4, pp. 37-51 (In Russ.). DOI: 10.31107/2075-1990-2020-437-51.

\section{BВEAEHИE}

Современный экономический рост во многих странах сопровожАается отрицательным внешним эффектом, проявляющимся в загрязнении окружающей среды, выбросами парниковых газов, глобальном потеплении, что впослеАствии может привести к угрозе жизни на планете. Соответственно, нужен переход от экстенсивного и ресурсонеэффективного экономического роста к устойчивому развитию и «зеленой" экономике.

Многие лидеры государств осознали эту проблему и декларируют переход К "зеленой» экономике, который требует огромных финансовых вложений. В настоящее время наблюАается существенный разрыв между объемом инвестиций, который необходим Аля реамизации этого перехода, и фактическим их объемом. Нынешний уровень “зеленых" инвестиций недостаточен Аля осуществления перехода. Ааже Аля стран Евросоюза на 2020 г. инвестиционный разрыв только в энергетической отрасли оценивается экспертами в 500 млн евро [Jacobsson R., Jacobsson S., 2012].

Цель Аанного исследования - выявить проблемы, сдерживающие развитие "зеленого" финансирования, и роль государства в решении этих проблем.

\section{ИСТОРИЯ ПРОБАЕМЫ}

В 1972 г. группа испанских экономистов представила Римскому клубу АоклаА о возможностях экономического и демографического роста в условиях истощения природных ресурсов. В докладе с использованием методов математического моделирования было представлено 12 сценариев развития, из которых семь сценариев можно определить как "благоприятные со средним и высоким потреблением", но Аля реализации которых нужны технологические, политические и социальные изменения [Медоуз А. Х. и Ар., 1991]. В 2004 г. эта группа исследователей преАставила Аругую работу поА названием «Пределы роста. 30 лет спустя", в которой были скорректированы предыдущие сценарии развития и был саелан вывоА, что время Аля реализации благоприятных сценариев упущено 
[Медоуз А. Х. и Ар., 2007]. Аля расчетов с целью оценивания влияния человека на окружающую среду ученые использовали параметр экологической нагрузки (экологический слеА. - Прим. ред.), разработанный М. Вакернагелем ${ }^{1}$. Оптимальной моделью авторы в новом периоде посчитали ограничение роста с совершенствованием технологий. Работы группы А. Медоуз стали пионерными в сфере “зеленой" экономики и оказали влияние на многих исследователей, ученых, политиков. Результатом стало изменение в 1970-1980 гг. политики в области экономического роста, улучшение экологических параметров в развитых европейских странах. В 1990-е ситуация изменилась в связи с ускоренным экономическим ростом развивающихся азиатских стран, в первую очередь Китая и Индии, который сопровождался высокими выбросами $\mathrm{CO}_{2}$. Статистика показывает, что выбросы $\mathrm{CO}_{2}$ всех стран Евросоюза в 3,2 раза меньше, чем в Китае ${ }^{2}$. По Аанным Института климатических изменений Грэнтема, 66 стран в мире несут ответственность за 88 \% выбросов на планете [Nachmany M. et al., 2014].

В табл. 1 представлены данные Всемирного банка о выбросах $\mathrm{CO}_{2}$ в странах, которые наиболее сильно загрязняют атмосферу. По объему загрязнений лидирует Китай, Россия находится на четвертом месте. По объему загрязнений на душу населения на первое место выходят США с показателем 16,6 т/чел. (тонн выбросов $\mathrm{CO}_{2}$ на одного человека), Россия занимает второе место с показателем 11,86 т/чел. По оценке загрязненности на основе экономического роста можно выделить Индию, гАе на 1 Аолл. экономического роста приходится 1,048 кг выбросов $\mathrm{CO}_{2}$ в окружающую среду. Экономику, в которой экономический рост сопровожАается таким загрязнением, называют "коричневой" экономикой. Россия с показателем загрязненности экономического роста 0,841 кг/Аомл. находится на третьем месте.

Таблица 1

\section{Выбросы загрязняющих атмосферу веществ $\left(\mathrm{CO}_{2}\right)$ по странам / Air pollutant emissions $\left(\mathrm{CO}_{2}\right)$ by country}

\begin{tabular}{|l|c|c|c|c|c|}
\hline Страна & $\begin{array}{c}\text { Выбросы } \\
\mathrm{CO}_{2}, \text { кт }\end{array}$ & $\begin{array}{c}\text { Аоля от } \\
\text { мировых } \\
\text { выбросов } \mathrm{CO}_{2}, \%\end{array}$ & $\begin{array}{c}\text { Выбросы } \mathrm{CO}_{2} \\
\text { на Аушу насе- } \\
\text { ления, т/чел. }\end{array}$ & $\begin{array}{c}\text { ВВП на Аушу } \\
\text { населения, } \\
\text { Аомл. США }\end{array}$ & $\begin{array}{c}\text { Выбросы } \mathrm{CO}_{2} \text { на } \\
\text { Аомлар экономичес- } \\
\text { кого роста, кг/Аомл. }\end{array}$ \\
\hline Китай & 10291926,88 & 28,5 & 7,54 & 7687,599 & 0,981 \\
\hline США & 5254279,285 & 14,5 & 16,6 & 55047,726 & 0,302 \\
\hline Индия & 2238377,137 & 6,2 & 1,65 & 1573,881 & 1,048 \\
\hline Россия & 1705345,684 & 4,7 & 11,86 & 14095,049 & 0,841 \\
\hline Япония & 1214048,358 & 3,4 & 9,54 & 38109,412 & 0,25 \\
\hline
\end{tabular}

Примечание: расчеты приведены по данным 2014 г., так как на сайте Всемирного банка это последние данные о выбросах $\mathrm{CO}_{2} /$ Note: The calculations are based on 2014 data, as on the World Bank website it is the latest data on $\mathrm{CO}_{2}$ emissions.

Источник: рассчитано автором по данным Всемирного банка (https://data.worldbank.org/indicator/EN.ATM. CO2E.KT?locations=RU\&name_desc=true) / Source: author's calculations based on the official data of the World Bank.

Аанная статистика показывает, что в России довольно высокие издержки экономического роста, это связано с тем, что экономический рост в РФ зависим от Аобычи природных углеродных ресурсов - нефти и газа.

ИзАержки экономического роста на глобальном уровне приводят к сокращению плодородных земель, дефициту питьевой воды, изменению климата. В результате воздействия

\footnotetext{
1 Экологическая нагрузка рассчитывается как площадь территорий, необходимых для того, чтобы обеспечить всем необходимым человека при современном стиле жизни.

2 https://data.worldbank.org/indicator/EN.ATM.CO2E.KT?locations=RU\&name_desc=true.
} 
человека на Землю природный капитал, вк^ючающий такие ресурсы, как пресная вода и пахотные земли, сократился в 116 из 140 стран [G20 Green Finance Study Group, 2016]. Вопросам перехода от ресурсной к экологически чистой "зеленой" экономике была посвящена Конференция ООН по устойчивому развитию в Рио-Ае-Жанейро в 2012 г., на которой большинство стран подтверАили приверженность к устойчивому развитию и выразили намерение «защищать климатическую систему на благо нынешних и будущих поколений на основе справеАливости и в соответствии с общей и Аифференцируемой ответственностью” ${ }^{3}$.

Знаковым событием XXI в. стала 21-я сессия Конференции сторон Рамочной конвенции Организации Объединенных Наций (PK OOH) об изменении климата, на которой было заключено соглашение (известное как Парижское соглашение) по борьбе с изменениями климата и активизации деятельности, необходимой Аля обеспечения устойчивого низкоуглеродного развития. Это соглашение подписали руководители 174 государств ${ }^{4}$.

Финансирование устойчивого экологически чистого экономического роста требует значительных инвестиций. Многочисленные исследования Международного энергетического агентства, Всемирного банка, Организации экономического сотрудничества и развития, Всемирного экономического форума указывают на то, что в течение ближайшего Аесятилетия необходимо направить десятки тримлионов домларов на финансирование "зеленых" проектов в области строительства, инфраструктуры, на очищение воды, экологическую утилизацию отходов.

\section{METOАОАОГИЯ}

В Аанной работе методом системного анализа и с помощью системного обзора литературы (CO $)$ рассматриваются подходы к определению “зеленых" финансов и раскрывается роль государства в "зеленом" финансировании. СОЛ включает рецензируемую академическую литературу и "серую" литературу, т. е. информацию в новостных изданиях, на сайтах, в официальных документах. Согласно алгоритму СО^ на первом этапе разрабатывается строка поиска, на втором этапе - анализ публикаций по источникам, на третьем этапе по Аисциплинам, на четвертом - проводится анализ Аинамики публикаций во времени и выявление ключевых событий.

В поисковой строке использовались следующие слова и фразы на английском и русском языках: "зеленые" финансы и роль государства в "зеленом" финансировании. На следующем этапе строка поиска была применена к следующим научным поисковым системам: электронные библиотеки, Scopus, SpringerLink, JSTOR, SSRN, eLibrary, Scholar Google. На третьем этапе просматривались по заголовкам, аннотациям, содержанию материалы как в научной, так и "серой" митературе. Если материалы не соответствовали заявленным требованиям поиска, они исключались из анализа.

При наборе ключевых слов role of the state in green finance в базах данных Scopus, SpringerLink было получено 168165 результатов, опубликованных до 30.05.2020. В основном митература по «зеленым" финансам опубликована в главах книг и статьях журналов. Это говорит о том, что исследования в Аанном направлении ведутся Аостаточно проАолжительное время и проблема еще Аалека от своего решения. Обращаем внимание на тот факт, что большинство публикаций написаны не одиночными авторами, а группами исследователей.

3 Будущее, которого мы хотим. Итоговый Аокумент конференции РИО+20. Конференция ООН по устойчивому развитию, 20-22 июня 2012 г. / Пер. с англ. URL: https://rio20.un.org/sites/rio20.un.org/files/ a-conf.216-I-1_russian.pdf.pdf.

4 Глобальные вопросы повестки Аня. Изменение климата / Организация Объединенных Наций, 2019. URL: https://www.un.org/ru/sections/issues-depth/climate-change/index.html. 
Основная Аоля публикаций, посвященных "зеленым" финансам, рассмотрена в сферах экономики и политических наук, а также международных отношений. Это позволяет саелать вывоА, что большинство ученых преАлагает решение экологических проблем с помощью экономических и политических методов.

Аинамику публикаций во времени удобно отслеживать в Scholar Google, так как там представлены рецензируемые научные публикации практически по всем научнопоисковым системам (рис. 1); на 30.05.2020 было обнаружено 1595200 публикаций на темy Role of the state in green finance. Аинамика публикаций проанализирована с 1992 г. по май 2020 г. 1992 г. был выбран в связи с тем, что в этом году была принята Рио-Ае-Жанейрская декларация по окружающей среде и развитию.

Рисунок 1

Аинамика публикаций по теме "зеленые" финансы в научно-поисковой системе Scholar Google с 1992 г. по май 2020 г. / The dynamics of publications on the green finance topic in the Scholar Google scientific search engine from 1992 to May 2020

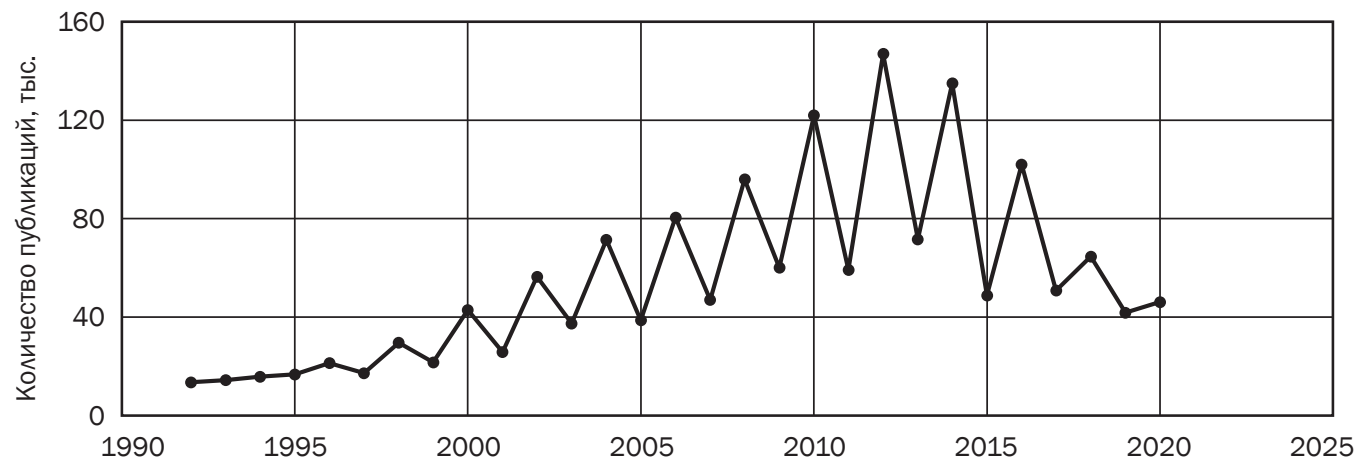

Источник: составлено автором по данным сайта Scholar Google / Source: compiled by the author based on scientific search engines.

Из рис. 1 виАно, что динамика публикаций имеет зигзагообразный характер. Заметные пики публикаций приходятся на 2010, 2012 и 2014 гг., что связано с проводимыми ООН конференциями и саммитами по изменению киимата и окружающей среды, на которых милеры государств Аокладывали о политике государства по сохранению окружающей среды и мерах по переходу к низкоугееродной экономике. Анализ тем и ключевых слов в Аинамике показал, что в исследованиях “зеленых" финансов можно выделить три этапа. Первый этап описан в работах А. Х. Медоуз и ее последователей и посвящен проблемам использования ограниченных природных ресурсов и загрязнения окружающей среды [Медоуз А. Х., 1991]. Второй этап связан с появлением понятий “зеленая" экономика, "зеленые" финансы, которые активно используются в сочетании с понятием "устойчивого роста" с начала 1990-х до начала 2000-х гг. Третий этап начинается с 2015 г. и продолжается по настоящее время, он ознаменуется появлением терминов "зеленая" революция, «зеленый" перехол [Фюкс Р., 2016, с. 173].

\section{ОСНОВНЫЕ ПОНЯТИЯ “ЗЕАЕНОГО" ФИНАНСИРОВАНИЯ}

На Аанный момент времени универсального общепризнанного определения "зеленого" финансирования не существует. Международные организации, финансовые учреждения, правительства определяют "зеленое" финансирование в соответствии со своими целям и мотивами. 
Примеры определений представлены в табл. 2.

\section{Примеры определений «зеленого" финансирования / Examples of green finance definitions}

\begin{tabular}{|c|c|c|}
\hline № & Организация & Определение «зеленого» финансирования \\
\hline 1 & $\begin{array}{l}\text { Рабочая группа G20 } \\
\text { по изучению } \\
\text { "зеленых" финансов }\end{array}$ & $\begin{array}{l}\text { Финансирование инвестиций, которые обеспечивают в широком смысле } \\
\text { экологически устойчивое развитие [G20 Green Finance Study Group, 2016, с. 3] }\end{array}$ \\
\hline 2 & $\begin{array}{l}\text { Организация } \\
\text { экономического } \\
\text { сотрудничества } \\
\text { и развития (ОЭСР) }\end{array}$ & $\begin{array}{l}\text { Финансирование Аля Аостижения экономического роста при одновременном } \\
\text { снижении загрязнения и выбросов парниковых газов, минимизации отходов и } \\
\text { повышении эффективности использования природных ресурсов [OECD, 2016] }\end{array}$ \\
\hline 3 & $\begin{array}{l}\text { Народный банк } \\
\text { Китая }\end{array}$ & $\begin{array}{l}\text { Политика, включающая политические и институциональные механизмы Аля } \\
\text { привлечения частных инвестиций в «зеленые» сферы деятельности, такие как } \\
\text { защита окружающей среды, энергосбережение, производство чистой энергии } \\
\text { посредством финансовых услуг, в т. ч. кредитование, фонды прямых инвестиций, } \\
\text { облигации, акции и страхование [People’s Bank of China, 2015, p. 2-4] }\end{array}$ \\
\hline 4 & $\begin{array}{l}\text { Правительство } \\
\text { Германии }\end{array}$ & $\begin{array}{l}\text { Стратегический поАхоА с включением финансового сектора в процесс перехода } \\
\text { к низкоуглеродной и ресурсоэффективной экономике в контексте климатических } \\
\text { изменений [Schaefer J., 2011, p. 4] }\end{array}$ \\
\hline 5 & $\begin{array}{l}\text { Федеральное } \\
\text { министерство } \\
\text { окружающей среды } \\
\text { Швейцарии }\end{array}$ & $\begin{array}{l}\text { Всестороннее участие индустрии финансовых услуг в Аостижении устойчивого } \\
\text { развития в результате согласования экономических, социальных и экологических } \\
\text { интересов [Buol J. et al., 2014, p. 4-5] }\end{array}$ \\
\hline 6 & $\begin{array}{l}\text { Экспертный совет } \\
\text { по рынку Аолгосрочных } \\
\text { инвестиций при Банке } \\
\text { России }\end{array}$ & $\begin{array}{l}\text { Вложения в экологически чистые и ресурсосберегающие технологии. Инвестиции } \\
\text { в различные программы и проекты, целью которых является развитие "зеленой" } \\
\text { экономики (см.: Зеленые финансы: повестка Аня Аля России (https://m.minfin.ru/ } \\
\text { common/upload/20181102_Green_finance.pdf)) }\end{array}$ \\
\hline
\end{tabular}

Источники: составлено автором на основе материалов международных организаций, финансовых и правительственных учреждений / Source: compiled by the author based on publications of international organizations, financial and government institutions.

Определениям, приведенным в табл. 2, присуща некоторая неоднородность, но в целом они схожи - во многих определениях присутствует ссылка на защиту окружающей среАы и финансирование перехода к низкоуглеродной экономике. В приведенных выше примерах можно выделить узкую и широкую трактовку "зеленых" финансов. Согласно узкой трактовке "зеленые" финансы - это инвестиции в низкоуглеродную экономику, или в "зеленый" экономический рост (определения под номерами 1, 2, 6). Согласно широкому подходу (определения $3,4,5)$ «зеленые" финансы - это не просто инвестиции, а политика, институциональный механизм, стратегический подхоА, т. е. Аействия, совершаемые сейчас и планируемые в Аолгосрочном периоде, направленные на стимулирование инвестиций в "зеленую" сферу деятельности.

Итальянские ученые Р. Берроу, Н. Чампони и В. Марини проводияи исследования существующих стандартов в определениях "зеленых" финансов и экономических секторов, в которых инвестируемые финансы можно определить как "зеленые" [Berrou R. et al., 2019]. Они выявили, что из инвестиций в 11 экономических секторов, которые считаются условно "зелеными", к спорным инвестициям (которые в одних странах считаются "зелеными", а в Аругих нет) можно отнести инвестиции в четыре сектора: 1) “чистая" энергия, в т. ч. ядерная энергетика, большие гиАроэлектростанции, экологически чистое произвоАство топлива, Аобыча полезных ископаемых; 2) энергоэффективность, в т. ч. энергоэффективность использования ископаемого топлива; 3) транспорт, в т. ч. железнодорожный; 4) контроль за загрязнениями и управление отходами (захоронение и сжигание отходов без использования энергии и газа). Появление таких спорных инвестиций затрудняет статистическую оценку объемов "зеленого" финансирования. 


\section{ПРОБАЕМЫ “ЗЕАЕНОГО» ФИНАНСИРОВАНИЯ И ГОСУААРСТВЕННЫЕ МЕРЫ ПОААЕРЖКИ}

В настоящее время можно отметить Аинамику роста в "зеленом" финансировании. По данным международной организации Climate Bonds Initiative, в 2019 г. были выпущены облигации и выданы кредиты, которые относятся к категории "зеленых", на сумму 254,9 млрА Аомл. США. Из общего объема 2019 г. такие кредиты составили всего 2,6 \% (6,8 млрА Аомм.)" ${ }^{5}$. Но Аанного финансирования неАостаточно Аля перехода к устойчивому росту. По оценкам экспертов ООН, Аля комплексного уАовлетворения "зеленых" потребностей необхоАимо 22 трлн АОмл. в гоАб.

Группа российских исследователей разделила факторы, сАерживающие "зеленый" рост, на факторы внешней и внутренней среды инвестирования. К факторам внешней среды авторы отнесли: 1) несовершенство рынка в сфере экологии; 2) консервативность (инерционность) характера экономического развития; 3) неАостаточно корректное измерение "зеленого" роста. Среди факторов внутренней среды авторы вылелими: 1) низкий уровень компетенций в финансовом секторе; 2) отсутствие эффективной системы мониторинга и контроля за соблюАением политики "зеленого" финансирования; 3) слабую Аиверсификацию “зеленых" инвестиций [Яковлев И. А. и Ар., 2017, C. 13-14].

В Аанном исследовании проблемы, сдерживающие рост "зеленого" финансирования, разделены на Аве группы: первая группа связана со специфичными характеристиками "зеленого" финансирования; вторая группа - с обычными проблемами Аолгосрочных проектов. К первой группе проблем относятся: отсутствие единообразного понимания категории "зеленых" финансов, институциональные причины сАерживания развития "зеленого" финансирования, трудности с оценкой внешнего эффекта, асимметрия информации, труАности с оценкой кредитных и рыночных рисков в "зеленом" финансировании. Основные проблемы второй группы связаны с неопределенностью и рискованностью вложений, что характерно Аля Аолгосрочных инвестиций.

Рассмотрим проблемы первой группы.

Отсутствие единообразного понимания категории "зеленых" финансов, что было описано в данной работе выше. Расхождение в трактовке понятий “зеленых" финансов, правил процедур видов деятельности, определенных под "зеленое" инвестирование, принятые в разных странах, "ограничивают возможности капиталовложений Аля иностранных инвесторов и международных финансовых организаций, так как они вынуждены тратить Аополнительные ресурсы на изучение особенностей национальных стандартов" [Богачева О. В., Смородинов О. В., 2017, с. 18].

Институциональные причины: инерционность усложняет переход К "зеленой" экономике, влияет на ценности, сознание людей, фирм, организаций, руководителей государств. Аля решения этих проблем необходимы не только преобразование формальных государственных и общественных институтов, изменение законодательства, но и воздействие на состояние неформальных институтов, формирование экологически ответственного потребления и производства на уровне индивидов, фирм, организаций, общества, государства. Необходимо проводить информационную кампанию Аля потребителей, чтобы они различали изделия и услуги, произведенные с помощью "зеленых" технологий. СлеАствием этой политики будет рост спроса на экологически чистую продукцию, а результатом -

\footnotetext{
5 Сидорович В. Объемы зеленого финансирования выросли на 50 \% и превысили 250 млрА Аом. в 2019 г. URL: https://renen.ru/green-financing-volumes-increased-by-50-and-exceeded-250-billion-in-2019/.

6 Аоклад Межправительственного комитета экспертов по финансированию устойчивого развития / ООН, 2015. C. 8. URI: https://www.un.org/esa/ffd/wp-content/uploads/2015/03/ICESDF_Ru.pdf.
} 
перенаправление инвестиций фирм и организаций с "грязного" производства на “чистое». На уровне государства политика Аолжна быть направлена на создание условий Аля роста "зеленого" финансирования, это может быть выражено, например, в отказе от субсиАирования добычи и использования ископаемого топлива ${ }^{7}$, так как подобные субсилии отрицательно влияют на стимулы перехода к "зеленой" экономике. С целью информирования сообщества о приоритетах национального развития во многих государствах приняты "дорожные карты" по инвестированию в "зеленые" проекты.

Трудности с оценкой внешнего эффекта. Положительные внешние эффекты при "зеленом" финансировании оценить трудно, так как выгоды от Аанного финансирования несут третьи стороны. Отрицательные внешние эффекты от "грязного" производства также трудно оценить. Это приводит к недостаточному инвестированию в "зеленые" виды Аеятельности и чрезмерному инвестированию в "грязные" виАы. Например, проект по возобновляемой энергии может иметь более высокие затраты на строительство, чем обычные альтернативы, и в отсутствие мер по получению выгоА от сокращения загрязнения рентабельность проекта становится слишком низкой Аля привлечения частных инвестиций.

Некоторые страны используют субсидии, налоговые льготы, льготные тарифы, системы торговли выбросами (ETS), стандарты портфеля возобновляемых источников энергии (RPS) и экологические нормы Аля решения проблем внешних эффектов с разной степенью успеха. Налоговая система может существенно влиять на стимулы инвесторов, например, Швеция и Нидерланды были первыми странами, которые ввели экологические налоги с целью перехода на экологически чистые виды деятельности. В России с 2002 г. бы^ введен налог на добычу полезных ископаемых и четыре налога на водные ресурсы. ОАнако Аля повышения доходности "зеленых" проектов одних налоговых стимулов неАостаточно, необходимы финансовые меры (гарантии, льготные займы, гранты и субсидии и пр.), которые повышают доходность таких проектов [G20 Green Finance Study Group, 2016].

Информационная асимметрия. Многие инвесторы заинтересованы во вложении инвестиций в "зеленые» проекты, но отсутствие экологической информации увеличивает "затраты поиска" таких проектов и снижает их привлекательность. Например, если инвесторы не располагают информацией об экологических показателях фирм, организаций, компаний (например, о выбросах $\mathrm{CO}_{2}$, потреблении энергии и воды, влиянии на климатические изменения), они не могут выявить и финансировать "зеленые" компании, а также управлять экологическими рисками. В качестве примера можно привести результаты опроса 24 ключевых инвесторов, проведенного группой G20 по изучению проблем, связанных с "зеленым" финансированием, в 2017 г. Анализ опроса показал, что основными причинами недостаточного финансирования являются семь нефинансовых причин, причем четыре из них связаны с асимметрией информации: недостаточная информация о выгодах от "зеленого" инвестирования, трудности Аля выхода международных инвесторов на местные рынки, неразработанные рейтинги и индексы, отсутствие аАресных ^ьгот Аля эмитентов «зеленых» облигаций [OECD, 2017, с. 52].

Немногие организации предоставляют информацию об экологических показателях фирм и о рисках. Аля решения этой проблемы в законодательства многих развитых стран внесены изменения, в которых от руководителей компаний требуется раскрывать информацию об экологических и климатических рисках. Например, в 2016 г. были внесены изменения в законодательство Австралии и был подготовлен Меморандум об обязанностях

7 OECD Policy Guidance for Investment in Clean Energy Infrastructure. An OECD Report to the G20, with Contributions by the World Bank and UNDP / OECD, 2013, p. 69. URL: https://www.oecd.org/daf/inv/investmentpolicy/CleanEnergyInfrastructure.pdf. 
руководителей компаний. В нем были выделены всего три крупные австралийские компании, которые публикуют информацию об экологических и климатических рисках в своих отчетах, и было отмечено, что большинство директоров не управляют должным образом климатическими рисками и могут быть привлечены к юриАической ответственности [Hutley N., Hartford-Davis S., 2016]. В 2019 г. Н. Хатли и С. ХатфорА-Аэвис выпустили Аополнения к меморандуму, в которых они показали изменения с 2016 г.: были внелрены новые системы отчетности с учетом экологических и климатических рисков, выросли требования со стороны инвесторов и общества к раскрытию информации; повысились судебные риски Аля руководителей компаний, не проявляющих Аолжной ответственности [Hutley N., Hartford-Davis S., 2019].

Информационную асимметрию усугубляет и разделенное управление Аанными между различными учреждениями. Аанные, собранные экологами об изменениях окружающей среды, не всегла передаются банкам и потенциальным инвесторам. Эта проблема решается в союзе государств, бизнеса, международных сообществ и организаций. Например, более 20 фондовых бирж выпустили руковоАство по раскрытию экологической информации Аля зарегистрированных на бирже компаний, и в ряле стран были введены обязательные требования к раскрытию информации. Отсутствие информации и неопределенность в политике приводят к чрезмерному неприятию риска инвесторами Аля проектов в области возобновляемых источников энергии, новых энергетических транспортных среАств и энергосберегающих технологий. Практика, принятая Аля решения этой проблемы в ряде стран, вкмючает:

- проекты, подаерживаемые государственными организациями (например, Банк зеленых инвестиций Великобритании);

- определение ясности в отношении перспектив политики в области устойчивого развития (например, Национальная политика экологически чистых технологий Малайзии, концепция Королевства Саудовская Аравия Ао 2030 г. и Основы государственной политики в области экологического развития Российской Федерации Ао 2030 г.);

- гарантии по кредитам со стороны государственных органов (например, программа гарантий по кредитам США Министерства энергетики Аля проектов возобновляемой энергии).

Трудности с оценкой кредитных и рыночных рисков в "зеленом" финансировании. Многие банки и институциональные инвесторы еще не разработали методики, способные идентифицировать и количественно оценить кредитные и рыночные риски, которые могут возникнуть в результате реализации проектов, и поэтому часто неАооценивают риски "коричневых" инвестиций и переоценивают риски "зеленых" инвестиций. Ао сих пор часто наблюдается чрезмерное финансирование проектов, связанных с загрязнением окружающей среды, а также неАостаточное инвестирование в "зеленые" проекты. Это было подчеркнуто в Аокладе рабочей группы по “зеленым" финансам (G20 Green Finance Study Group) в 2016 г.: если экологический риск недооценивается, то капитал будет перераспределен в более рискованные виды деятельности [UNEP, 2016].

Понимание экологических рисков имеет важное значение Аля эффективного учета экологических факторов в процессе принятия решений и, следовательно, Аля мобилизации "зеленых" инвестиций.

К проблемам второй группы, общим Аля большинства Аолгосрочных проектов, относят ограничения банковской финансовой системы по долгосрочным ресурсам, низкий уровень капитализации банковской системы, высокие инвестиционные риски, изменение государственных режимов регулирования инвестиций. Нежелательным результатом проявления этих проблем является несоответствие сроков погашения облигаций и кредитов потребностям финансового обеспечения "зеленых" проектов. Это связано 
с превышением спроса на долгосрочное финансирование над преАложением, что приводит к дефициту инвестиций в инфраструктуру, в том числе в проекты "зеленой" инфраструктуры. Финансирование Аолгосрочных проектов сильно зависит от банковского креАитования, в то время как банки имеют ограниченные возможности по преАоставлению Аолгосрочных креАитов Аефицита "Алинных" Аенег в банковской системе.

Примеры нововведений в финансовом секторе, которые могут помочь решить эту проблему, вк^ючают "зеленые» облигации, ценные бумаги, обеспеченные активами (ABS), Аоходные компании (Yieldcos), обеспеченные кредиты.

"Зеленые" облигации - важный инструмент в "зеленом" финансировании, отличительной чертой которого является вложение долгосрочных инвестиций в энергоэффективные проекты. Рынок “зеленых" облигаций обладает высоким потенциалом роста (рис. 2).

Рисунок 2

\section{Аинамика выпуска "зеленых" облигаций / The dynamics of green bonds issuance}

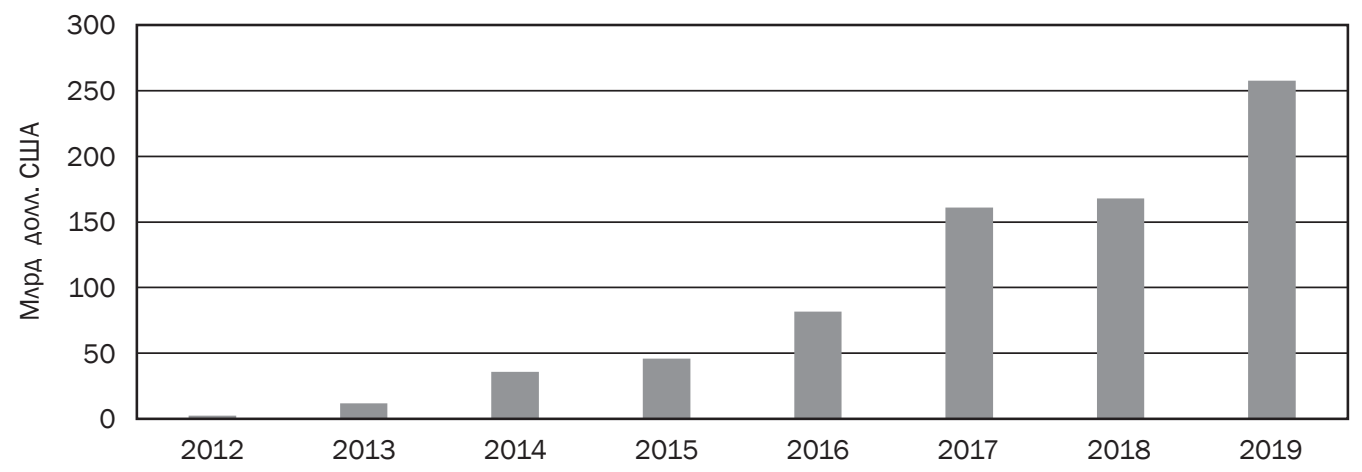

Источник: составлено автором по данным Climate Bonds Initiative (https://www.climatebonds.net/) / Source: compiled by the author based on data of the Climate Bonds Initiative (https://www.climatebonds.net/).

На рис. 2 виден стремительный рост выпуска "зеленых" облигаций. В 2012 г. было выпущено облигаций на сумму всего 2,6 млрА Аомл., к 2019 г. - на сумму 257,7 млрА Аомл. То есть наблюдается увеличение выпуска "зеленых" облигаций в 99 раз. Эмитентами "зеленых" облигаций являются крупные международные организации, такие как Всемирный банк, Европейский инвестиционный банк, правительства стран Польши, Германии, Франции; национальные банки: Народный банк Китая, Банк Америки; крупные корпорации: Apple, Toyta, Engie; муниципальные и государственные учреждения разных стран [Cowan G., 2017].

Ценные бумаги, обеспеченные активами (ABS), также используются в "зеленом" финансировании. Их потенциал определяется через преобразование пула конвертируемых неликвидных активов в пул торгуемых ценных бумаг. Этот инструмент инвестирования не особо популярен в "зеленом" финансировании и составлял в 2016 г. "менее 11 \% заемного инвестирования в развитие низкоуглеродных технологий" [Порфирьев Б., 2016, c. 7].

Аоходные компании (Yieldcos) - вариант инвестирования, ориентированный на экологические Аолгосрочные проекты в сфере возобновляемых источников энергии, способные привлечь финансовые ресурсы. Типовой размер актива Аля формирования подобной компании составляет 500 млн Аомл. США [Порфирьев Б., 2016, с. 10].

На основании вышеизложенного можно сАелать вывоА, что развитие “зеленого" финансирования возможно только при активном участии государства. 


\section{ОСНОВНЫЕ ГОСУААРСТВЕННЫЕ МЕРЫ ПОААЕРЖКИ “ЗЕАЕНОГО" ФИНАНСИРОВАНИЯ}

Многие страны используют налоги, субсидии и законы Аля решения экологических проблем. Эти Аействия вносят существенный вклаА в увеличение "зеленых" инвестиций, но в целом объемы государственного и частного капитала остаются недостаточными.

За последнее десятилетие в обществе выработались следующие принципы "зеленого" финансирования: надежное кредитование и окупаемые инвестиции, повышенные требования к раскрытию информации и управлению окружающей средой. Появились финансовые продукты, такие как «зеленые" кредиты, "зеленые» облигации, инвестиционные фонды "зеленой" инфраструктуры и пр.

В табл. 4 показана роль государства и государственных механизмов в решении проблем инвестирования "зеленых" финансов, описанных в предыдущих пунктах данной статьи.

Таблица 3

\section{Роль государства и государственные меры воздействия в решении проблем инвестирования "зеленых" финансов /} Role of the state and state actionsin solving the problems of green investing

\begin{tabular}{|c|c|c|c|c|}
\hline № & Проблема & Следствие проблемы & Роль государства & Методы государственного воздействия \\
\hline 1 & $\begin{array}{l}\text { Отсутствие } \\
\text { единообразного } \\
\text { понимания } \\
\text { категории } \\
\text { "зеленые" } \\
\text { финансы }\end{array}$ & $\begin{array}{l}\text { Ограничение } \\
\text { возможностей } \\
\text { капиталовложений } \\
\text { Аля внутренних } \\
\text { и иностранных } \\
\text { инвесторов }\end{array}$ & $\begin{array}{l}\text { Информа- } \\
\text { ционная }\end{array}$ & $\begin{array}{l}\text { Государство Аолжно развивать норма- } \\
\text { тивно-правовую базу Аля инвесторов } \\
\text { В «зеленом» финансировании, в которой } \\
\text { нужно обозначить к^ючевые стандарты } \\
\text { и определения "зеленых» стандартов } \\
\text { и проектов. Необходима гармонизация } \\
\text { международных стандартов с нацио- } \\
\text { нальными стандартами [Богачева О. В., } \\
\text { Смородинов О. В., 2017, с. 18] }\end{array}$ \\
\hline 2 & $\begin{array}{l}\text { Институци- } \\
\text { ональные } \\
\text { проблемы }\end{array}$ & $\begin{array}{l}\text { Недостаточные } \\
\text { стимулы перехода } \\
\text { к «зеленой" } \\
\text { экономике }\end{array}$ & $\begin{array}{l}\text { Информа- } \\
\text { ционная } \\
\text { Координи- } \\
\text { рующая }\end{array}$ & $\begin{array}{l}\text { Информирование населения об ответ- } \\
\text { ственном потреблении и производстве. } \\
\text { Разработка концепций Аолгосрочного } \\
\text { развития с учетом экологической сос- } \\
\text { тавляющей. Разработка национальных } \\
\text { руководств и стандартов по "зеленым" } \\
\text { финансам. Создание “Аорожных карт" } \\
\text { [OECD, 2015] }\end{array}$ \\
\hline 3 & $\begin{array}{l}\text { Трудности } \\
\text { с оценкой } \\
\text { внешнего } \\
\text { эффекта }\end{array}$ & \begin{tabular}{|l} 
Недостаточное \\
инвестирование \\
в «зеленые» виды \\
Аеятельности
\end{tabular} & $\begin{array}{l}\text { Информа- } \\
\text { ционная } \\
\text { Экспертно- } \\
\text { аналитическая } \\
\text { Контрольная }\end{array}$ & $\begin{array}{l}\text { ПровеАение экспертизы проектов с } \\
\text { учетом экологической состав^яющей. } \\
\text { Разработка экологических норм. } \\
\text { Создание системы торговли выбросами, } \\
\text { использование субсидий и налоговых } \\
\text { ^ьгот Аля корректировки стоимости } \\
\text { "зеленых" проектов Аля инвесторов. } \\
\text { ПодАержка "зеленых" проектов } \\
\text { государственными организациями }\end{array}$ \\
\hline 4 & $\begin{array}{l}\text { Трудности с оцен- } \\
\text { кой кредитных и } \\
\text { рыночных рисков } \\
\text { в "зеленом" } \\
\text { финансировании }\end{array}$ & $\begin{array}{l}\text { Недооценка риска } \\
\text { "коричневых" } \\
\text { инвестиций. Переоценка } \\
\text { рисков "зеленого" } \\
\text { инвестирования }\end{array}$ & $\begin{array}{l}\text { Информа- } \\
\text { ционно- } \\
\text { аналитическая } \\
\text { Регулирующая }\end{array}$ & $\begin{array}{l}\text { Проведение экспертизы проектов } \\
\text { с учетом экологической составляющей. } \\
\text { Создание системы торговли выбросами, } \\
\text { в т. ч. А^я корректировки стоимости } \\
\text { и оценки риска “коричневых" проектов }\end{array}$ \\
\hline 5 & $\begin{array}{l}\text { Общие проблемы } \\
\text { финансирования } \\
\text { Аолгосрочных } \\
\text { проектов }\end{array}$ & $\begin{array}{l}\text { Несоответствие сроков } \\
\text { погашения облигаций и } \\
\text { кредитов поА "зеленые" } \\
\text { проекты потребностям } \\
\text { инвестирования в такие } \\
\text { проекты }\end{array}$ & Стимулирующая & $\begin{array}{l}\text { Предоставление гарантий, системы } \\
\text { страхования банкам Аля стимулирова- } \\
\text { ния инвестиций в "зеленые" проекты } \\
\text { Запуск регулируемых государством } \\
\text { нововведений в финансовом секторе: } \\
\text { выпуск “зеленых" облигаций, ценных } \\
\text { бумаг, обеспеченных активами ABS, } \\
\text { создание доходных компаний (Yieldcos) }\end{array}$ \\
\hline
\end{tabular}

Источник: составлено автором / Source: compiled by the author. 
В решении первой проблемы государство исполняет информационную роль посреАством информирования общества о стратегии, целях и задачах в области "зеленого" финансирования с помощью государственных Аокументов. ОАним из таких Аокументов является "Основы государственной политики в области экологического развития Российской Федерации на периол Ао 2030 года» ${ }^{8}$, в котором в качестве одной из целей государства указан переход на "зеленые" технологии, а в качестве механизма реализации государственной политики - создание нормативно-правовой базы экологической оценки. Развитие нормативно-правовой базы необходимо Аля инвесторов в "зеленом" финансировании. В Аокументах нужно определить ключевые понятия в сфере “зеленого" финансирования: "зеленые" стандарты, "зеленые" финансы, "зеленые" проекты. Очень важно, чтобы национальные стандарты были гармонизированы с международными стандартами в Аанной сфере. Подобная информация позволит инвесторам адекватно оценить риски реализации "зеленых" проектов и расширит возможности капиталовложений Аля зарубежных инвесторов.

При решении второй проблемы государство исполняет Аве роли: информационную и координирующую. Государство с помощью СМИ информирует население об ответственном потреблении и производстве. Успешным проявлением этой политики будет рост спроса на продукцию, произведенную с помощью "зеленых" технологий. Государство информирует общество о создании условий Аля "зеленого" финансирования через Концепцию Аолгосрочного развития, указы президента ${ }^{9}$, национальные проекты (в Российской Федерации). Из всех национальных проектов только в национальном проекте “Экология" подробно описаны условия "зеленого" финансирования и развития “зеленых" технологий в Российской Федерации.

Государство выполняет роль координатора, когда участвует в разработке национальных руководств и стандартов по "зеленым" финансам и созданию "дорожных карт". Например, Республика Корея запустила алгоритм - "дорожную карту" "зеленого" финансирования в 2009 г. [Oh D., Kim S.-H., 2019, с. 3], Китай - в 2015 г.; в России в 2019 г. принята "Аорожная карта" организации национального центра по развитию "зеленых" финансов ${ }^{10}$.

При решении третьей и четвертой проблем государство Аолжно помочь инвесторам в проведении оценки внешнего эффекта от внедрения "зеленых" технологий. В Аанном случае государство способствует экспертизе проектов с учетом экологической составляющей, при оценке проекта учитывает стоимость загрязнения на основе ETS, субсидий и налоговых льгот, которые снижают первоначальные инвестиции в "зеленые" проекты и уменьшают риски "зеленого" инвестирования.

В решении пятой проблемы госуАарство Аолжно созАавать стимулы Аля инвесторов в «зеленые" проекты, которым присущи риски Аолгосрочного инвестирования. С этой целью государство преАоставляет гарантии, способствует развитию системы страхования банков и нововведений в финансовом секторе. Во многих странах Евросоюза государство проводит эмиссию "зеленых" облигаций, ценных бумаг, обеспеченных активами ABS, способствует созданию доходных компаний (Yieldcos).

\footnotetext{
8 “Основы государственной политики в области экономического развития Российской Федерации на период Ао 2030 года" (утв. Президентом РФ 30.04.2012). URL: http://www.consultant.ru/document/cons_doc_ LAW_129117/.

9 Указ президента России “О национальных целях и задачах развития Российской Федерации Ао 2024 гоAа".

${ }^{10}$ Концепция по организации в России методологической системы по развитию зеленых финансовых инструментов и проектов ответственного инвестирования / Экспертный совет по рынку долгосрочных инвестиций при Банке России. М., 2019. URL: https://cbr.ru/Content/Document/File/84163/press_ 04102019.pdf.
} 


\section{ЗАКАЮЧЕНИЕ}

На основании вышеизложенного можно слелать вывоА, что в обществе растет понимание, что переход к "зеленой" экономике требует значительных финансовых затрат и во многих странах наблюдается значительный разрыв между уровнем "зеленых" инвестиций и объемом финансов, необходимых для перехода к низкоуглеродной экономике [Zademach H. M., Ditchrl J., 2016].

Исследование выявило проблемы, сдерживающие развитие "зеленого" финансирования. ОАна из них - это отсутствие универсального общепризнанного определения "зеленые" финансы, необходимость гармонизации понятий и стандартов в данной сфере, что позволит увеличить масштабы "зеленого" финансирования за счет привлечения международных инвесторов.

Инерционность и зависимость от пути предшествующего развития также сдерживает развитие "зеленого" финансирования, так как Аля перехода к "зеленой" экономике нужна трансформация в сознании потребителей и производителей, чтобы осуществить перехоА к ресурсоэффективным чистым технологиям.

Трудности с оценкой внешнего эффекта от применения “зеленых" технологий и оценкой кредитных и рыночных рисков сАерживают частный сектор от инвестирования в проекты "зеленой" экономики. Часто крупные фирмы выбирают оплату тарифов за загрязнения, а не замену технологий на производстве. В таком случае задача государства - стимулирование перенаправления инвестиций в сферу “зеленой" экономики.

Аля решения проблем «зеленого" финансирования необходим союз государства, экомогических межАународных организаций, банков и фирм, т. е. многосторонний союз. Государственный сектор Аолжен играть важную роль в информировании, координации, стимулировании, регулировании и контроле деятельности в области «зеленых» финансов. Аля решения проблемы недостаточного “зеленого" финансирования необходимо использовать комплекс финансовых и нефинансовых инструментов: это развитие нормативноправовой базы, проведение экологической экспертизы проектов, помощь в оценке креАитного риска, разработка комплексных Аолгосрочных планов с совместным участием государства и бизнеса.

\section{Список источников}

Богачева О. В., Смородинов О. В. Проблемы "зеленого финансирования" в странах G20 // Мировая экономика и межАународные отношения. 2017. Т. 61. № 10. С. 16-24. URL: https://doi.org/10.20542/0131-22272017-61-10-16-24.

Медоуз А. Х., Медоуз А. А., Рэндерс Й., Беренс В. В. Пределы роста. АоклаА по проекту Римского клуба "Сложное положение человечества" / Пер. с англ. М.: ИзА-во МГУ, 1991. 207 с.

Медоуз А., Рэндерс Й., Медоуз А. Пределы роста. 30 лет спустя / Пер. с англ. М.: ИКЦ “Академкнига", 2007. 342 c.

Порфирьев Б. "Зеленые” тенденции в мировой финансовой системе // Мировая экономика и межАународные отношения. 2016. Т. 60. № 9. С. 5-16. URL: https://doi.org/10.20542/0131-2227-2016-60-9-5-16.

Фюкс Р. Зеленая революция: Экономический рост без ущерба Аля экологии / Пер. с нем. М.: Альпина нон-фикшн, 2016. 336 с.

Яковлев И. А., Кабир ^. С., Никулина С. И. и Ар. Финансирование "зеленого" экономического роста: концепции, проблемы, подходы // Научно-исслеАовательский финансовый институт. Финансовый журнал. 2017. № 3 (37). C. 9-21.

Berrou R., Ciampoli N., Marini V. Defining Green Finance: Exciting Standards and Main Challenges / Migliorelli V., Dessertine P. (eds). The Rise of Green Finance in Europe. Palgrave Macmillan, 2019. P. 31-51. URL: https://doi. org/10.1007/978-3-030-22510-0.

Buol J., Buomberger B., Meier K. et al. Overview of the "Green" Swiss Financial Market / Commissioned by: Federal Office for the Environment (FOEN). Information Paper, October 2014. URL: https://www.sustainablefinance. ch/upload/cms/user/20151031_pwc_green_swiss_financial_market_e.pdf. 
Cowan G. Investors Warm to "Green Bonds" // The Wall Street Journal. 2017. April 9. URL: https://www.wsj. com/articles/investors-warm-to-green-bonds-1491790201.

Environmental Risk Analysis by Financial Institutions - a Review of Global Practice. An Input Paper for the G20 Green Finance Study Group / UNEP, 2016. URL: http://unepinquiry.org/wp-content/uploads/2016/09/ 2_Environmental_Risk_Analysis_by_Financial_Institutions.pdf.

Establishing China's Green Financial System. Theoretical Framework of Green Finance / Research Bureau of the People's Bank of China, UNEP Inquiry. 2015. URL: http://unepinquiry.org/wp-content/uploads/2015/04/ ECGFS_Background_Paper_A_Theoretical_Framework.pdf.

G20 Green Finance Synthesis Report / G20 Green Finance Study Group, 2016. URL: https://unepinquiry.org/ wp-content/uploads/2016/09/Synthesis_Report_Full_EN.pdf.

Green Investment Banks. Scaling up Private Investment in Low-carbon, Climate-resilient Infrastructure / Green Finance and Investment. Paris: OECD Publishing, 2016. URL: https://doi.org/10.1787/9789264245129-en.

Hutley N., Hartford-Davis S. Climate Change and Directors's Duties. Supplementary Memorandum of Opinion / Centre for Policy Development, 2019. URL: https://apo.org.au/sites/default/files/resource-files/2019-03/ apo-nid227561.pdf.

Hutley N., Hartford-Davis S. Climate Change and Directors's Duties. Memorandum of Opinion / Centre for Policy Development and Future Business Council, 2016. URL: https://apo.org.au/sites/default/files/resourcefiles/2016-10/apo-nid74091.pdf.

Jacobsson R., Jacobsson S. The emerging funding gap for the European energy sector - Will the financial sector deliver? // Environmental Innovation and Societal Transitions. 2012. Vol. 5. P. 49-59. URL: https://doi. org/10.1016/j.eist.2012.10.002.

Mapping Channels to Mobilise Institutional Investment in Sustainable Energy / Green finance and investment. Paris: OECD Publishing, 2015. URL: https://doi.org/10.1787/9789264224582-en.

Mobilising Bond Markets for a Low-Carbon Transition / Green Finance and Investment, Paris: OECD Publishing, 2017. URL: https://doi.org/10.1787/9789264272323-en.

Nachmany M. et al. The GLOBE Climate Legislation Study. A Review of Climate Change Legislation in 66 Countries. Fourth Edition. London: GLOBE International and the Grantham Research Institute, 2014. URL: https://www.Ise. ac.uk/granthaminstitute/wp-content/uploads/2014/03/Globe2014.pdf.

Oh D., Kim S.-H. Green Finance in the Republic of Korea. In: Sachs J., Woo W., Yoshino N. et al. (eds.). Handbook of Green Finance. Sustainable Development. Singapore: Springer, 2019. URL: https://doi.org/10.1007/978-98110-8710-3_10-1.

Schaefer J. Green Finance. An Innovative Approach to Fostering Sustainable Economic Development and Adaption to Climate Change. GIZ, 2011. URL: https://www.greengrowthknowledge.org/sites/default/files/downloads/ resource/Green_finance_GIZ.pdf.

Zademach H.-M., Dichtl J. Greening Finance and Financing the Green: Considerations and Observations on the Role of Finance in Energy Transitions / Jones A., Ström P., Hermelin B. et al. (eds.). Services and the Green Economy. London: Palgrave Macmillan, 2016. URL: https://doi.org/10.1057/978-1-137-52710-3_7.

Поступила в редакцию 17 июля 2020 г. Принята к публикации 19 августа 2020 г.

\section{References}

Bogachova O., Smorodinov O. (2017). Challenges to Green Finance in G20 Countries. Mirovaya ekonomika i mezhdunarodnye otnosheniya - World Economy and International Relations, vol. 61, no. 10, pp. 16-24 (In Russ.). Available at: https://doi.org/10.20542/0131-2227-2017-61-10-16-24.

Berrou R., Ciampoli N., Marini V. (2019). Defining Green Finance: Exciting Standards and Main Challenges. In: Migliorelli V., Dessertine P. (eds.). The Rise of Green Finance in Europe. Palgrave Macmillan, P. 31-51. Available at: https://doi.org/10.1007/978-3-030-22510-0.

Buol J., Buomberger B., Meier K. et al. (2014). Overview of the "Green" Swiss Financial Market. Commissioned by: Federal Office for the Environment (FOEN). Information Paper, October. Available at: https://www.sustainablefinance. ch/upload/cms/user/20151031_pwc_green_swiss_financial_market_e.pdf.

Cowan G. (2017). Investors Warm to "Green Bonds". The Wall Street Journal, April 9. Available at: https://www. wsj.com/articles/investors-warm-to-green-bonds-1491790201.

Fücks R. (2013). Intellegent washsen. Die grüne Revolution. München: Hanser, 364 p.

G20 Green Finance Study Group (2016). G20 Green Finance Synthesis Report. Available at: http://unepinquiry. org/wpcontent/uploads/2016/09/Synthesis_Report_Full_EN.pdf.

Hutley N., Hartford-Davis S. (2016). Climate Change and Directors's Duties. Memorandum of Opinion. Centre for Policy Development and Future Business Council. Available at: https://apo.org.au/sites/default/files/resourcefiles/2016-10/apo-nid74091.pdf. 
Hutley N., Hartford-Davis S. (2019). Climate Change and Directors's Duties. Supplementary Memorandum of Opinion. Centre for Policy Development. Available at: https://apo.org.au/sites/default/files/resource-files/2019-03/ apo-nid227561.pdf.

Jacobsson R., Jacobsson S. (2012). The emerging funding gap for the European energy sector - Will the financial sector deliver? Environmental Innovation and Societal Transitions, vol. 5, pp. 49-59. Available at: https://doi. org/10.1016/j.eist.2012.10.002.

Meadows D.H., Meadows D.L., Randers J., Behrens W.W. (1972). The Limits to Grow. A Report for the Club of Rome's Project on the Predicament of Mankind. NY: Universe books, 205 p.

Meadows D., Randers J., Meadows D. (2004). Limits to Growth. The 30-Year Update. Chelsea Green Publishing, $368 \mathrm{p}$.

Nachmany M. et al. (2014). The GLOBE Climate Legislation Study. A Review of Climate Change Legislation in 66 Countries. Fourth Edition. London: GLOBE International and the Grantham Research Institute. Available at: https:// www.lse.ac.uk/granthaminstitute/wp-content/uploads/2014/03/Globe2014.pdf.

OECD (2015). Mapping Channels to Mobilise Institutional Investment in Sustainable Energy. Green finance and investment. Paris: OECD Publishing. Available at: https://doi.org/10.1787/9789264224582-en.

OECD (2016). Green Investment Banks. Scaling up Private Investment in Low-carbon, Climate-resilient Infrastructure. Green Finance and Investment. Paris: OECD Publishing. Available at: https://doi.org/10.1787/ 9789264245129-en.

OECD (2017). Mobilising Bond Markets for a Low-Carbon Transition, Green Finance and Investment. Paris: OECD Publishing. Available at: https://doi.org/10.1787/9789264272323-en.

Oh D., Kim S.-H. (2019). Green Finance in the Republic of Korea. In: Sachs J., Woo W., Yoshino N. (eds). Handbook of Green Finance. Sustainable Development. Singapore: Springer. Available at: https://doi.org/10.1007/978-98110-8710-3_10-1.

People's Bank of China. UNEP Inquiry (2015). Establishing China's Green Financial System. Theoretical Framework of Green Finance. Available at: http://unepinquiry.org/wp-content/uploads/2015/04/ECGFS_Background_ Paper_A_Theoretical_Framework.pdf.

Porfir'ev B. (2016). Green Trends in the Global Financial System. Mirovaya ekonomika i mezhdunarodnyye otnosheniya - World Economy and International Relations, vol. 60, no. 9, pp. 5-16 (In Russ.). Available at: https:// doi.org/10.20542/0131-2227-2016-60-9-5-16.

Schaefer J. (2011). Green Finance. An Innovative Approach to Fostering Sustainable Economic Development and Adaption to Climate Change. GIZ. Available at: https://www.greengrowthknowledge.org/sites/default/files/ downloads/resource/Green_finance_GIZ.pdf.

UNEP (2016). Environmental Risk Analysis by Financial Institutions - a Review of Global Practice. An Input Paper for the G20 Green Finance Study Group. Available at: http://unepinquiry.org/wp-content/uploads/2016/09/ 2_Environmental_Risk_Analysis_by_Financial_Institutions.pdf.

Yakovlev I.A., Kabir L.S., Nikulina S.I. et al. (2017). Financing Green Economic Growth: Conceptions, Problems, Approaches. Finansovyj žhurnal - Financial Journal, no. 3, pp. 9-21. (In Russ.).

Zademach H.-M., Dichtl J. (2016). Greening Finance and Financing the Green: Considerations and Observations on the Role of Finance in Energy Transitions. In: Jones A., Ström P., Hermelin B. et al. (eds.). Services and the Green Economy. London: Palgrave Macmillan. Available at: https://doi.org/10.1057/978-1-137-52710-3_7.

Received 17.07.2020

Accepted for publication 19.08.2020 


\title{
Углеродные биржи: европейский опыт развития механизма торговли разрешениями на выбросы
}

\author{
Светлана Викторовна Аорошенко, А. э. Н., профессор кафедры эконометрики \\ и статистики Уральского федерального университета им. первого Президента \\ России Б. Н. Ельцина, г. Екатеринбург; завеАующая сектором региональной \\ преАпринимательской политики Института экономики УрО РАН, г. Екатеринбург \\ E-mail: doroshenkos@mail.ru, ORCID 0000-0002-8282-6062 \\ Анна Амитриевна Мингалева, магистрант специальности "Международный \\ менеАжмент" Института экономики и управления Уральского феАерального \\ университета им. первого Президента России Б. Н. Ельцина, г. Екатеринбург; \\ магистрант Университета Ка Фоскари, г. Венеция (Италия) \\ E-mail: mingaleva.ann@yandex.ru, ORCID 0000-0003-1564-8240
}

\begin{abstract}
Аннотация
Система торговли разрешениями на выбросы парниковых газов считается в настоящее время одним из наиболее перспективных механизмов воздействия на климатические проблемы. ОАнако регулирующая функция Аанного механизма не так положительно однозначна, как это преАставляют международные организации, а его создание, функционирование и распространение в глобальном масштабе сталкивается с множеством препятствий.

В статье представлены основные результаты исслеАования процесса создания и развития системы торговли разрешениями на выбросы $\mathrm{CO}_{2}$, реализуемой более 15 лет в ЕС. С целью выявления проблем в функционировании механизма торговли разрешениями на выбросы $\mathrm{CO}_{2}$ проведен поэтапный анализ его развития в рамках $E C$, выявлены основные институциональные препятствия в Аействующем механизме. Проведен анализ особенностей его применения, выявлены сильные и слабые стороны функционирования, Аана оценка перспектив развития. В результате исследования сАелан вывоА, что вследствие наличия объективных противоречий и неАостатков в существующем механизме торговли разрешениями на выбросы $\mathrm{CO}_{2}$ его действие не позволяет обеспечить те результаты по уменьшению объемов выбросов и сокращению загрязнения, которые зафиксированы в плановых Аокументах ООН и ЕС по экологическому регулированию. Основным препятствием является невозможность Аостичь в современных условиях согласования интересов множества заинтересованных сторон по сокращению выбросов, что провоцирует эффект "утечки углерода".
\end{abstract}

Ключевые слова: торговля разрешениями на выбросы, ETS EC, углеродные биржи, регулирующая оАносторонность, утечка углерода, квоты, парниковый эффект

JEL: Q52, Q54, Q56, Q58

Аля цитирования: Аорошенко С. В., Мингалева А. А. Углеродные биржи: европейский опыт развития механизма торговли разрешениями на выбросы // Финансовый журнал. 2020. T. 12. № 4. C. 52-68. DOI: 10.31107/2075-1990-2020-4-52-68. 
DOI: 10.31107/2075-1990-2020-4-52-68

\title{
Carbon Exchanges: European Experience in Developing the Mechanism of Emission Permit Trading
}

\section{Svetlana V. Doroshenko ${ }^{1,2}$}

E-mail: doroshenkos@mail.ru, ORCID 0000-0002-8282-6062

\section{Anna D. Mingaleva ${ }^{1,3}$}

E-mail: mingaleva.ann@yandex.ru, ORCID 0000-0003-1564-8240

${ }^{1}$ Ural Federal University named after the first President of Russia B.N. Yeltsin, Yekaterinburg 620002, Russian Federation

2 Institute of Economics of the Ural Branch of the RAS, Yekaterinburg 620014, Russian Federation

${ }^{3}$ Ca' Foscari University of Venice, Venice VE, 30123, Italy

\begin{abstract}
The system for trading permits for greenhouse gas emissions is currently being presented as one of the most promising mechanisms for influencing climate problems. However, the regulatory function of this mechanism is not as positively unambiguous as it is represented by international organizations, and its creation, operation and distribution on a global scale are facing many obstacles.

The article presents the main results of a study on the process of creating and developing a system for trading in permits for $\mathrm{CO}_{2}$ emissions, implemented in the $\mathrm{EU}$ for more than 15 years. In order to identify problems in the functioning of the mechanism for trade in permits for $\mathrm{CO}_{2}$ emissions, a phased analysis of development within the EU has been carried out, and the main institutional obstacles in the existing mechanism have been detected. The analysis of the features of its application is then performed, the strengths and weaknesses of the functioning are determined, and the development prospects are assessed.

As a result of the study, it is concluded that, due to the presence of objective contradictions and shortcomings in the existing mechanism for trading permits for $\mathrm{CO}_{2}$ emissions, its validity in its current form does not allow one to achieve the results on reducing emissions and pollution recorded in the UN and EU planning documents on environmental regulation. The main obstacle is the inability to reach, in modern conditions, coordination of the interests of many stakeholders in reducing emissions, which provokes the effect of "carbon leakage".
\end{abstract}

Keywords: trading permits for $\mathrm{CO}_{2}$ emissions, EU ETS, carbon exchanges, regulating one-sidedness, carbon leakage, quotas, greenhouse effect

JEL: Q52, Q54, Q56, Q58

For citation: Doroshenko S.V., Mingaleva A.D. Carbon Exchanges: European Experience in Developing the Mechanism of Emission Permit Trading. Financial Journal, 2020, vol. 12, no. 4, pp. 52-68 (In Russ.). DOI: 10.31107/2075-1990-2020-4-52-68.

\section{ВBEAEHИE}

Активно продвигаемой на межАународном уровне идеей, сформулированной в РКИК ООН и реализуемой в рамках данной программы, является создание углеродных рынков и механизма торговли разрешениями на выбросы (emission permit trading), что призвано стать более эффективным, чем существующая система налогообложения [Baranzini A. et al., 2017; Laing T. et al., 2014; Dechezleprêtre A., Sato M., 2017]. Этот механизм Аолжен обеспечить Аостижение целей реализации климатических действий, направленных на стимулирование основных субъектов-загрязнителей воздуха - как стран, так и преАприятий - к сокращению производимых ими выбросов углекислого газа, закиси азота 
и перфторуглеродов ${ }^{1}$. В настоящее время в мире существует более 17 национальных и межАународных систем квотирования выбросов парниковых газов. При этом наибо^ее развитой и глобально значимой является Система торговли выбросами Евросоюза (EU Emission Trading Scheme, ETS EC) $)^{2}$, которая была запущена в 2005 г. и до сих пор остается краеугольным камнем стратегии ЕС по Аекарбонизации экономики, а также крупнейшей системой торговли выбросами в мире [Verde S. F., 2020]. Значимость ETS EC Аля мирового киимата определяется тем, что с ее помощью регулируется около 45 \% выбросов в $\mathrm{EC} \mathrm{CO}_{2}$, производимых более чем 11000 генерирующими установками.

В соответствии с экономической ^огикой, положенной в основу разработки схемы управления выбросами углерода, "углеродные рынки реализуют меры реагирования на изменение климата, находя возможности сокращения выбросов с наименьшими затратами" [Bryant G., 2016, p. 878]. Тем не менее существующий механизм постоянно пробуксовывает и в течение всего периода действия не позволил Аостичь запланированных в Аокументах $\mathrm{OOH}$ и ЕС по экологическому регулированию целей и показателей по уменьшению объемов выбросов и сокращению загрязнения.

Анализ процесса создания и поэтапного развития торговли разрешениями на выбросы в европейских странах показывает, что практическое внедрение Аанного механизма регулирования сталкивается с рядом трудностей, которые пока не преодолены. Соответственно, это требует поиска причин возникновения (и сохранения) таких трудностей и путей их преодоления.

\section{МЕТОАЫ ИССАЕАОВАНИЯ}

Изучение и оценка эффективности воздействия ETS EC на экономическую и экологическую обстановку в отдельных странах и мире в целом, а также ее влияния на конкурентоспособность отАельных преАприятий сталкивается с рядом объективных методологических и аналитических трудностей.

Во-первых, сами зарубежные исследователи отмечают отсутствие Аостаточно полной и своевременно собранной статистической базы по ключевым показателям оценки эффективности (effectiveness) и рентабельности (efficiency) ETS EC, позволяющей оценить результативность как самой системы, так и степень ее воздействия на ключевые показатели отАельных хозяйствующих субъектов, секторов экономики и стран в целом, включая затраты на мероприятия по сокращению выбросов $\mathrm{CO}_{2}$, выгоды, получаемые от участия в ETS EC, Аинамику конкурентоспособности субъектов и стран, совокупные объемы выбросов $\mathrm{CO}_{2}$ и т. А. [Verde S. F., 2020; Löschel A. et al., 2019]. Это затрудняет использование экономико-математических и эконометрических методов Аля получения надежных количественных характеристик процесса борьбы с выбросами $\mathrm{CO}_{2}$, ограничивает проведение ситуационного анализа, а также достаточно масштабных и сопоставимых между собой расчетов по странам, секторам экономики или по отдельным группам покупателей квот. Многие эконометрические исследования оказались неактуальными уже сразу после опубликования статей и отчетов, что снижает их научную и нормативную ценность [Verde S. F., 2020, p. 335].

Во-вторых, существует серьезная методологическая проблема потери актуальности результатов различных исслеАований вслеАствие быстрого изменения ситуации. Процесс создания и развития ETS EC прошел почти полных три стадии - в 2020 г. заканчивается третья стадия (2013-2020 гг.) и начинается переход К четвертой стадии (2021-2030 гг.).

\footnotetext{
1 Именно эти три вида вредных выбросов составляют в настоящее время наибольший удельный вес в структуре парниковых газов и контролируются наиболее тщательно.

2 EU Emissions Trading System (EU ETS). URL: https://ec.europa.eu/clima/policies/ets_en.
} 
Нужно отметить, что выделяемые этапы в развитии ETS EC характеризуются Аостаточно сильными различиями в базовых инструментах управления механизмом торговли квотами на выбросы $\mathrm{CO}_{2}$ и разным уровнем воздействия ETS EC на экономическую и экологическую обстановку в мире. Но поскольку появление различных научных публикаций (кроме официальных Аокументов ООН, ЕС, ОЭСР и Ар.) происходит с существенной задержкой во времени, то это аналогично с эконометрическими исследованиями резко снижает научную и сравнительную ценность более ранних исследований, а также их значимость Аля обоснования практических рекомендаций.

Предварительный анализ научной митературы показал, что большая часть результатов исследований относится к первому (2005-2008 гг.) ${ }^{3}$ и/или второму (2009-2012 гг.) этапам создания ETS EC [Ellerman A. D. et al., 2016; Hintermann B. et al., 2016; Muûls M. et al., 2016]. ^ишь небольшое число работ охватывает первые годы третьего этапа [Verde S. F., 2020]. ОАновременно в рамках третьего этапа также вылеляются Ава различных с экономической точки зрения периода, первый из которых охватывает 2013-2017 гг., а второй - 2018-2020 гг. и отличается резким ростом цен на углерод, начавшимся в конце 2017 г., в результате чего менее чем за гоА цены выросли в четыре раза с 5 до 25 евро. В середине 2018 г. произошла стабилизация цен, которые с тех пор менялись незначительно, но ситуация с COVID-19 может внести серьезные поправки к концу 2020 г.

Анализ динамики цен на углеродных биржах ЕС показал, что начиная с 2005 г. уровень цен на углерод несколько раз менялся очень резко. Так, первый скачок цен на рынке $\mathrm{CO}_{2}$ произошел в 2008 г. в результате мирового финансово-экономического кризиса. Но он по времени совпал с переходом от первого этапа ко второму, Аля которого уже были предусмотрены серьезные изменения в механизме торговли и регулирования, что несколько сгладило влияние Аанного скачка. Второй (также незапланированный) скачок цен на рынке $\mathrm{CO}_{2}$ относится к 2012 г. Он изменил как количество покупателей лицензий (оно сократилось), так и объемы поступления средств в фонды климатического регулирования. Следующий серьезный четырехкратный скачок цен произошел в 2017-2018 гг. сразу же после того, как было Аостигнуто окончательное политическое соглашение по реформе Аля четвертого этапа. ОАнако ситуация с коронавирусом и общим экономическим кризисом в странах ЕС может снова изменить ценовую ситуацию на рынке $\mathrm{CO}_{2}$.

Что касается научных публикаций 2019-2020 гг., то, как уже отмечалось, часть из них посвящена анализу результатов функционирования ETS EC на третьем этапе, но большинство опирается на статистические Аанные до 2018 г., что искажает результаты и выводы. ОАнако Аля современного этапа необходимы более актуальные оценки возАействия ETS EC на экономические и экологические показатели развития мировой экономики и отАельных стран. Отставание в научном анализе данных и потеря актуальности эконометрических расчетов и результатов являются одной из серьезных методологических проблем в данной области исследований.

В силу вышеизложенного в качестве основного метода настоящего исследования был выбран библиографический анализ зарубежных источников с акцентом на нормативные Аокументы РКИК ООН, ЕС, ОЭСР, связанные с реформированием системы регулирования выбросов парниковых газов. Анализ литературных источников включал научные статьи за последние Ава года, в которых уже учтены особенности функционирования ETS EC после принятия политического решения о ее реформировании и перехода к четвертому этапу.

3 Первый этап создания ETS EC начался в 2005 г. в качестве трехлетнего пилотного проекта, в ходе которого отрабатывались основные механизмы управления и финансирования. 


\section{ОБЗОР АИТЕРАТУРЫ}

Изучение зарубежной литературы показало, что Аля определения эффективности EU ETS с точки зрения ее влияния на объемы выбросов углекислого газа и уровень конкурентоспособности европейских преАприятий как внутри региона, так и на глобальном уровне большинство исследователей опиралось на анализ следующих направлений: Аинамика сокращения выбросов парниковых газов, Аинамика цен на квоты и влияние EU ETS на экономические показатели компаний, влияние EU ETS на конкурентоспособность и на инновации [Aus dem Moore N. et al., 2019; Martin R. et al., 2016; Dechezleprêtre A. et al., 2019].

Имеются современные работы, оценивающие влияние системы торговли выбросами в Европейском союзе на показатели выбросов углерода и экономические показатели отдельных компаний, а также секторов экономики [Segura S. et al., 2018; Koch N., Mama H. B., 2019; Cadez S. et al., 2019; Joltreau E., Sommerfeld K., 2019]. Так, исследование А. Аешезлепретре, А. Нахтигамла и Ф. Венманса посвящено анализу совокупного влияния ETS EC на показатели выбросов углерода и экономические показатели развития Европейского союза в целом [Dechezleprêtre A. et al., 2018]. В работе K. Бур, С. Рот и П. Стигсона, опирающейся на анализ политики в области изменения климата, которая реализуется с помощью глобального режима торговли выбросами, исследуются возможности поиска компромисса между участниками переговоров и заинтересованными сторонами [Buhr K. et al., 2014]. Эта фундаментальная статья является актуальной и сегодня, поскольку Аостижение согласия по распределению ответственности за климатические изменения между большим количеством участников с разными интересами и финансовыми возможностями пока остается нереализованным. В этом контексте актуален и Отчет Аля Европейской комиссии, подготовленный большой группой исследователей [de Bruyn S. et al., 2015], гАе проводится комплексный сравнительный анализ влияния передачи ответственности за регулирование выбросов парниковых газов в ETS EC, проверенный Аля шести секторов экономики ЕС. Аналогичный анализ преАставлен в ряде работ того же периода Аля отАельных секторов европейской промышленности: электроэнергетики [Tian Y. et al., 2016; Pereira da Silva P. et al., 2016], цементной и сталелитейной промышленности [Branger F. et al., 2016], алюминиевой промышленности [Sartor O., 2012].

ОАнако если говорить о статистическом обосновании положительного или отрицательного влияния ETS на выбросы углерода и на изменение климата, то, по мнению самих зарубежных исследователей, весомых доказательств такого влияния нет. В апреле 2020 г. С. Верде представил проведенный им расширенный анализ эконометрических исслеАований, в которых проверяется наличие эффектов роста или снижения конкурентоспособности компаний и стран, вызванных системой торговли выбросами ЕС. ВерАе пришел к выводу, что “на сегодняшний Аень нет никаких свидетельств того, что ETS EC оказала широко распространенное негативное или положительное влияние на конкурентоспособность регулируемых фирм" [Verde S. F., 2020, р. 320]. Также им установлено, что в имеющихся эконометрических исследованиях наблюдается некоторая неоднородность оценочных эффектов. К числу методологических недостатков (с точки зрения выбора объекта анализа) Верде отнес отсутствие анализа секторальных структур, слабое изучение наличия Аолгосрочного эффекта влияния ETS EC на экономику через отток инвестиций или Аинамику фирмы, а также отсутствие (за небольшим исключением) эконометрических оценок и анализа утечек углерода (см., например, работы [Branger F., Quirion P., 2014; Dechezleprêtre A. et al., 2019; Reinaud J., 2008]).

Что касается оценки типа и силы связей межАу экологическими и экономическими показателями, то обзор митературы показал наличие различных подходов и выявленных связей. При этом нужно отметить, что нейтральная взаимосвязь [Elsayed K., Paton D., 2005] и отрицательная зависимость [Sarkis J., Cordeiro J. J., 2001] Аоказывались и обсуждались 
на ранних этапах исследований, еще Ао создания ETS EC. Более поздние исследования отмечают положительную связь межАу этими показателями [Molina-Azorín J. F. et al., 2009; Lopez-Gamero M. D. et al., 2009; Segura S. et al., 2018; Klemetsen M. E. et al., 2016].

Таким образом, научные публикации по вопросам эффективности действия ETS EC, ее влияния на конкурентоспособность компаний, секторов экономики и стран, объемы выбросов, уменьшение парникового эффекта весьма разнообразны, Аостаточно неоднородны и противоречивы. Объясняется это наличием многочисленных проблем и противоречий в Аействии механизма торговли разрешениями на выбросы $\mathrm{CO}_{2}$.

Аля того чтобы понять причины пробуксовки механизма торговли разрешениями на выбросы и нежелания многих стран присоединяться к международному рынку торговли углеродом, необходимо выявить сильные и слабые стороны в Аействии Аанного механизма в настоящих условиях.

\section{ПОРЯАОК АЕЙСТВИЯ ЕТS ЕС И ЕЕ ПРЕИМУЩЕСТВА}

Механизм торговли разрешениями на выбросы $\mathrm{CO}_{2}$ EC (ETS EC) опирается на традиционный экономический подход к решению проблемы сокращения загрязнения окружающей среды с помощью формирования у субъектов загрязнения (фирм-загрязнителей) ${ }^{4}$ экономических стимулов Аля сокращения выбросов. Это классический рыночный поАХоА, поскольку «поощряет поведение с помощью рыночных сигналов, а не через четкие Аирективы, касающиеся уровней или методов контроля загрязнения" [Stavins R. N., 2001, p. 2].

Схема действия Аанного механизма следующая. Центральный орган устанавливает объем совокупного ежегодного загрязнения окружающей среды от всех источников загрязнения и отдельно по видам. На основе этого устанавливаются максимально Аопустимые в текущем году объемы выбросов определенных количеств определенного загрязнителя, которые формируют ежегодную квоту. Аалее эта квота (разделенная на отдельные кицензии на загрязнение) продается конкретным загрязнителям - регулируемым фирмам.

Загрязнители (преАприятия топливно-энергетического сектора, транспортные преАприятия, промышленные предприятия и т. А.) обязаны иметь разрешение на выбросы в количестве, установленном, исходя из их фактического уровня. В 2009 г. Европейская комиссия четко установила, что количество квот, получаемых каждым загрязнителем, не Аолжно превышать уровень выбросов $\mathrm{CO}_{2}$, соответствующих его произвоАственной программе. Установление такого верхнего предела на выбросы $\mathrm{CO}_{2}$ позволит создать Аефицит лицензий, необходимый Аля торговли, и, следовательно, обеспечит нормальную (высокую) цену на мицензии.

Эффективная реализация этой цели предполагает ежегодное точное определение количества квот, получаемых каждой установкой (загрязнителем), Аля которой была проведена точная оценка выбросов. Если реальный объем выбросов у конкретного загрязнителя оказывается меньше, то владелец мицензии может продать часть своей квоты другому загрязнителю, выбросы которого оказались больше запланированного. Загрязнители, которые хотят увеличить свои выбросы, покупают разрешения у Аругих, желающих их продать.

В системе ограничения и торговли, такой как ETS EC, цены на углерод определяются взаимодействием межАу спросом и преАложением квот на выбросы. Также цена на углерод зависит от возможности свободной передачи квот. Если рынок квот эффективен, то предельные затраты на снижение выбросов оказываются выровненными по всем загрязнителям (регулируемым операторам) посреАством торговли квотами, что является наиболее простым и дешевым способом сокращения выбросов.

4 В нормативных Аокументах ETS EC Аля обозначения таких субъектов загрязнения используются термины "регулируемые фирмы", "регулируемые операторы", "установки". 
Таким образом, первое и гмавное преимущество применения механизма торговли разрешениями на выбросы $\mathrm{CO}_{2}$ определяется как автоматическое выравнивание аммокации вредных выбросов, обеспечивающее их постепенное сокращение.

При использовании механизма торговли разрешениями на выбросы $\mathrm{CO}_{2}$ происходит свободное и добровольное перераспределение прав на загрязнение окружающей среды от тех загрязнителей, которым эти права не нужны, к тем, которым они требуются Аля улучшения бизнеса. Например, при росте объемов производства (появление новых заказов) квоты на загрязнение, равной объему прошлого периода, может не хватить Аля потребностей бизнеса. Таким образом, механизм торговли разрешениями на выбросы $\mathrm{CO}_{2}$ оказывает прямое положительное влияние на бизнес и на общество в целом [Marin G. et al., 2018].

Bо-вторых, у механизма торговли разрешениями на выбросы $\mathrm{CO}_{2}$ как рыночного инструмента регулирования есть важное преимущество, оказывающее непосредственное влияние на технологию производства и на уровень технологического развития как отАельных предприятий, так и общества в целом. А именно, при использовании механизма торговли разрешениями на выбросы $\mathrm{CO}_{2}$ фирма может сократить свои собственные выбросы путем модернизации производства, ввода новых очистных сооружений и т. А. [Lundgren T. et al., 2015]. В таком случае фирма также может продать появившиеся у нее "излишки" возможностей загрязнения тем компаниям, которые не укладываются в предоставленные им квоты. В частности, отмечается, что "преимущества экологического менеАжмента превышают затраты" на его реализацию, "а более жесткие нормативные стандарты стимулируют зеленые инновации" [Segura S. et al., 2018, p. 1113]. В целом делается вывод, что механизм торговли разрешениями на выбросы $\mathrm{CO}_{2}$ стимулирует инновационную и "зеленую" составляющие конкурентоспособности преАприятий [Costantini V., Mazzanti M., 2012].

B-третьих, активно декларируемым преимуществом от применения инструмента торговли разрешениями на выбросы $\mathrm{CO}_{2}$ является тезис о том, что в рамках Аанного механизма создается система добровольного распределения ответственности между загрязнителями за сокращение загрязнения в целом. При использовании механизма торговли разрешениями на выбросы $\mathrm{CO}_{2}$ ответственность за снижение загрязнения возлагается на те фирмы, которые могут Аостичь этого с меньшими затратами (дешевле), а также на те фирмы, у которых больше потенциал Аля сокращения загрязнения. В то же время те фирмы, технологические возможности которых не позволяют существенно снижать уровень загрязнения (а при росте объемов производства приводят к увеличению совокупных объемов выбросов), могут вести свой бизнес, не опасаясь серьезных санкций (в виде налогов, штрафов, запрета вести Аеятельность) путем выкупа квот. При этом цена на покупаемую часть квоты может устанавливаться выше первоначальной в соответствии с ценностью этой квоты Аля покупателя. Таким образом реализуется главное правило экономической Аеятельности и рынка - плата за конкретный ресурс (загрязнение) производится исходя из ценности ресурса Аля покупателя. Тем самым Аостигается приближение к оптимальности общественного распределения ресурсов на рынке парниковых газов.

Наконец, в-четвертых, к преимуществам механизма торговли разрешениями на выбросы $\mathrm{CO}_{2}$ часто относят существующую в этом случае у фирм возможность учитывать стоимость кицензии при планировании собственных обстоятельств по снижению выбросов и возможность встроить стоимость лицензии в свой процесс планирования, а также заранее оценивать ее влияние на прибыль компании [Үu Н., 2013], на стоимость акций [Bernardini E. et al., 2019] и т. А.

Несмотря на наличие явных теоретических и практических преимуществ от применения системы торговли разрешениями на выбросы, существующие торговые системы, включая европейскую систему (ETS EC), характеризуются рядом неАостатков, затрудняющих их эффективное функционирование. 


\section{ПРОБАЕМЫ И НЕАОСТАТКИ \\ ПРИМЕНЕНИЯ МЕХАНИЗМА ТОРГОВАИ РАЗРЕШЕНИЯМИ НА ВЫБРОСЫ $\mathrm{CO}_{2}$}

Первой серьезной проблемой Аействующего механизма торговли разрешениями на выбросы $\mathrm{CO}_{2}$ является существование и широкое распространение в его рамках оппортунистического поведения фирм и целых стран по типу "проблемы безбилетника".

"Проблема безбилетника" была и остается очень важной Аля повышения эффективности мероприятий по улучшению климата и успешной борьбы с выбросами парниковых газов. В настоящее время ситуация сложилась так, что многие страны не заинтересованы в том, чтобы брать на себя обязательства по внедрению низкоуглеродных технологий, по реализации дорогостоящих инвестиционных проектов в области создания альтернативных источников энергии, по общему снижению выбросов. Это происходит в силу существования индивидуальных национальных интересов, когАа отдельные государства желают, чтобы другие страны несли бремя сокращения выбросов, а сами пытаются его избежать. Многие страны, особенно слаборазвитые и развивающиеся, мотивируют такой прямой отказ тем, что из-за недостаточно развитой экономики и промышленности их выбросы значительно меньше, чем у высокоразвитых стран. Поэтому их усилия и обязательства Аолжны быть меньше. Более того, ряд государств утвержАает, что их природа и сельское хозяйство сильно постраАали от "заноса" на их территории выбросов из Аругих стран, и требуют выплаты им дополнительной компенсации, а не наложение излишних финансовых и инвестиционных "климатических" обязательств. Чаще всего в межрегиональном распространении загрязнения обвиняются высокоразвитые страны, которые за счет своей промышленности и энергетики вносят значительный вклаА в выбросы углерода и тем самым создают негативный эффект как Аля самих себя, так и Аля соседних стран.

Попытки решить "проблему безбилетника" и уклонения ряда стран от экологической ответственности Ао сих пор не увенчались успехом. Более Авадцати лет переговоров на ежегодных климатических конференциях $\mathrm{OOH}$ по поводу участия всех стран в борьбе с климатическими изменениями и предпринимаемых попыток Аостигнуть соглашения между странами по сохранению климата и сокращению выбросов не привели к успеху. Ааже на Малрилской конференции в Аекабре 2019 г. переговоры закончились практически провалом, поскольку участвовавшие в ней делегаты почти из 200 стран так и не Аоговорились по тексту заключительного коммюнике.

Проблема "безбилетника" естественным образом поддерживается и за счет принятой в рамках Парижского соглашения так называемой регулирующей односторонности. Регулирующая односторонность означает, что государство берет на себя обязательства по поводу создания и предоставления определенных на национальном уровне взносов. В то же время государства могут действовать самостоятельно, когАа они разрабатывают конкретные мероприятия в рамках этих планов и определяют степень их достижения.

Второй проблемой при применении ETS EC является наличие эффекта утечки углероАа. Практика установления односторонних цен на углерод (проблема “безбилетника", проблема политики одностороннего смягчения послеАствий изменения климата в открытой экономике) нашла свое выражение в явлении, получившем название "утечка углерода" [Dechezlepretre A. et al., 2019]. ПоА "утечкой углерода" подразумевается простое смещение выбросов парниковых газов из одних регионов в Аругие, вызванное различными уровнями строгости экологического законодательства и смягчения послеАствий Аля климата. "Сокращение внутренних выбросов в результате ухудшения конкурентоспособности в какой-то мере компенсируется более высокими выбросами в странах, гАе политика по смягчению послеАствий изменения климата отсутствует или менее строгая" [Verde S. F., 2020, p. 321]. 
Таким образом, важной причиной возникновения утечки углерода является ухудшение конкурентоспособности компаний и стран вслеАствие жесткого климатического регулирования. Если регион, принимающий более строгие углеродные нормативы, является Аостаточно важным с точки зрения спроса на ископаемое топливо, утечка углерода также может быть результатом более низких мировых цен на ископаемое топливо. В ^юбом случае одностороннее установление цен на углерод может сопровождаться мерами по защите от его потенциальных неблагоприятных послеАствий.

Таким образом, проблема одностороннего ценообразования на углерод (утечки углерода) остается весьма актуальной, поскольку вызываемые ею негативные последствия трудно преодолеваются на практике. При этом различные гипотезы, предполагающие перемещение производства с высоким уровнем загрязнения в страны с более слабой экологической политикой, подтвержАаются определенными эмпирическими Аанными [Grether J.-M. et al., 2012]. За периоА существования ETS EC накопился большой объем научных эконометрических исследований, посвященных доказательствам влияния ETS EC на конкурентоспособность и связанную с этим утечку углерода [Ellerman A. D. et al., 2010; Branger F., Quirion P., 2014; Naegele H., Zaklan A., 2019].

Третьей проблемой при применении ETS EC является то, что Аля формирования эффективной торговли правами первостепенное значение имеет правильное первоначальное установление прав собственности на загрязнения, их первоначальных объемов и первоначальной цены, а также свободы для их передачи (продажи). Если это требование не соблюдено, то эффективность механизма торговли мюбыми объектами, в том числе разрешениями на выбросы $\mathrm{CO}_{2}$, снижается. Так, при завышенных объемах и/или заниженной цене у загрязнителей пропадает стимул к поиску путей снижения объемов выбросов: квоты и так закрывают весь объем выбросов, а низкая цена слабо сказывается на себестоимости и на конечной цене готовой продукции. С Аругой стороны, при заниженных объемах и/или завышенной цене на мицензию у загрязнителей отсутствует экономическая возможность к расширению бизнеса и росту объемов производства, поскольку высокая цена лицензии (квоты) сказывается на повышении конечной цены готовой проАукции, а заниженный объем квоты требует физического сокращения выбросов, что при отсутствии возможности их сократить ${ }^{5}$ накладывает физическое ограничение на объем производства.

Аанное явление стало причиной провала ETS EC на ее первом этапе. Распределение резервов и оценки выбросов Аля первого этапа (2005-2007 гг.) были проведены в 2004 г. и основывались на фактически Аостигнутом уровне выбросов в предыдущие годы. В результате верхний потолок объемов выбросов и объемы квот были завышены. Цена на квоты в 2005 г. колебалась в пределах 5-10 евро, постепенно Аостигнув 25-30 евро к концу апреля 2006 г. ОАнако заявление нескольких стран ЕС, что их выбросы в 2005 г. были ниже, чем ожидалось, привело к резкому падению цен. У многих предприятий-загрязнителей возник излишек квоты. ОАнако перенести эти излишки на второй этап в виле опреАеленного резерва на непредвиденные обстоятельства по правилам первого этапа было невозможно. Поэтому предприятия-загрязнители начали их активно продавать, переполнив рынок к концу года. В результате цена упала практически до нуля (Ао нескольких евроцентов).

Второй этап внеАрения ETS EC начался в 2008 г. На этом этапе правила изменились, и было разрешено переносить квоты на последующие этапы. В итоге с начала года цена квот Аостигла почти 30 евро, оАнако в результате экономического кризиса она

\footnotetext{
5 Например, в силу особенностей технологического процесса, при отсутствии Аостаточных финансовых среАств Аля провеАения кардинальной модернизации произвоАства и очистных сооружений и по целому ряду Аругих причин.
} 
снизилась к концу 2008 г. примерно на 50 \%. После восстановления углеродных рынков в 2009 г. наступил примерно Авухлетний период стабильности цен на уровне 12-17 евро за тонну (Ао лета 2011 г.), после которого цены снова упали примерно Ао 4-7 евро. С начала 2013 г. (начало третьего этапа функционирования ETS EC) цена на углерод неуклонно росла, поскольку квоты второго этапа можно было использовать на третьем этапе и в последующие годы. Учитывая, что объемы квот будут ежегодно сокращаться в соответствии с установленными планами сокращения выбросов $\mathrm{CO}_{2}$, эти сохраненные резервы могут быть использованы предприятиями, особенно в ситуации, когАа рост объема произвоАства запланирован в размере, превышающем установленные на кажАый гоА ограничения [Ellerman A. D. et al., 2016; Muûls M. et al., 2016; Hintermann B. et al., 2016]. Аинамика цен на квоты $\mathrm{CO}_{2}$ за анализируемый период приведена на рис. 1.

Рисунок 1

\section{Аинамика цен на ETS EC на квоты $\mathrm{CO}_{2}$ в 2005-2015 гг., евро за тонну $\mathrm{CO}_{2} /$ The dynamics of the prices of the of EUA prices in the period 2005-2015, euro a ton of $\mathrm{CO}_{2}$}

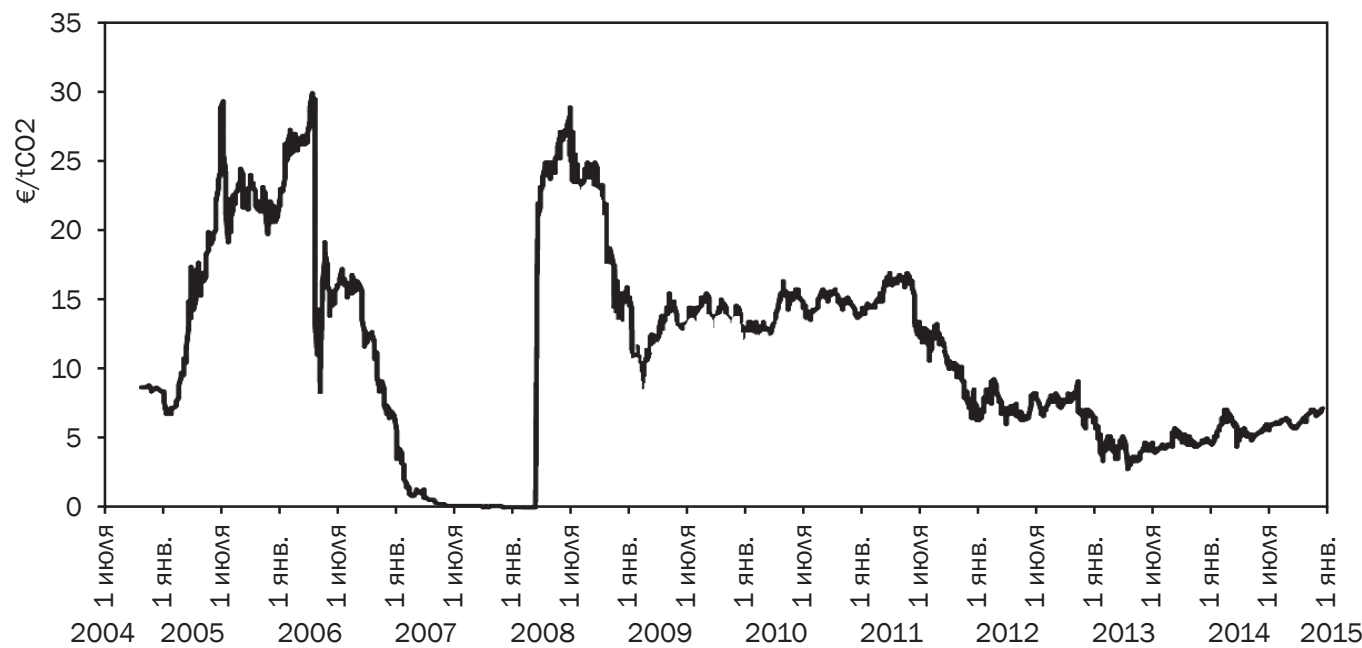

Источник: приведено авторами по [Borghesi, S., Montini M., 2016, p. 4] / Source: cited by the authors [Borghesi S., Montini M., 2016, p. 4].

ОАнако, как уже отмечалось, ситуация на рынке выбросов $\mathrm{CO}_{2}$ меняется очень быстро. Кроме того, остается открытым вопрос экономических и социальных послеАствий панАемии COVID-19. Поэтому Аля повышения эффективности функционирования ETS EC необхоАимо существование свободного рынка продажи прав на загрязнения, преАполагающее высокий уровень свободы для их передачи (продажи).

Четвертая проблема связана с возможным сокращением прибыли и снижением потенциала инновационного развития и технологической модернизации производства. В частности, в последнее время все чаще поднимается вопрос о том, что если индивидуальные расходы фирм на ввод новых очистных сооружений, проведение модернизации производства и замену технологии окажутся больше, чем стоимость полной квоты, то фирма не будет заинтересована в модернизации технологических мощностей в целом и очистных сооружений в частности, а будет ежегодно покупать стандартный Аля нее объем квот на выбросы, поскольку в цене готовой продукции стоимость кицензии будет меньше, чем затраты на модернизацию.

Нужно отметить, что многочисленные исследования, посвященные эмпирическому Аоказательству гипотезы Портера о том, что рыночная экологическая политика (например, 
установление цен на углерод) может привести к повышению конкурентоспособности за счет стимулирования новых производственных процессов и инновационных продуктов, оказались неубедительными [Brannlund R., Lundgren T., 2009; Ambec S. et al., 2013; Dechezlepretre A., Sato M., 2017; Verde S. F., 2020].

Появившиеся в последние годы работы европейских авторов на эту тему показали, что в соответствии с ETS EC регулируемые фирмы могут принимать Аорогостоящие меры по сокращению выбросов за счет инноваций или покупать ^ицензии, тем самым уменьшая свою норму прибыли. ОАнако они могут повысить эффективность своей Аеятельности, просто получая бесплатные квоты (Laing et al., 2014). Именно такая ситуация и наблюдалась весь периоА Аействия ETS EC. В частности, эта проблема является неактуальной Аля тех предприятий, которые работают на ^окальных рынках: например, при производстве электроэнергии, тепловой энергии (на ТЭЦ), при производстве и поставках коммунальных услуг, при производстве пара и т. А. На таких рынках Аанный эффект технологической зависимости от правил покупки мицензий не будет проявляться, Т. К. продажа этих виАов товаров (услуг) ограничена институциональными и техническими аспектами (местными и европейскими рынками). Поэтому, учитывая, что первоначально механизм ETS EC охватывал только выбросы $\mathrm{CO}_{2}$ и был сосредоточен в основном на производителях электроэнергии ${ }^{6}$ и предприятиях энергоемких обрабатывающих отраслей ${ }^{7}$, Аанная проблема на практике даже не возникала.

ОАнако поэтапное расширение списка и номенклатуры покупателей мицензий, включение в их перечень промышленных фирм Аругих отраслей может оказаться более многоплановым, в частности может возникнуть объективная "невозможность пройти через стоимость углерода без потери доли рынка" [Segura S. et al., 2018, p. 1113]. В таких случаях результатом будет более низкий уровень производства и занятости. Аругим вариантом выхода из создавшегося положения может быть перемещение углеродоемких компаний в нерегулируемые страны, что еще больше скажется на сокращении рабочих мест. Кроме того, регулируемые фирмы могут потерять Аолю рынка, уступив ее конкурирующим фирмам за пределами действия ETS EC [Martin R. et al., 2016].

Осознавая перечисленные выше проблемы и препятствия Аля успешной реализации системы торговли выбросами в странах ЕС, 27 февраля 2018 г. Совет ЕС официально оАобрил реформу Системы торговли выбросами ЕС на период 2021-2030 гг. ${ }^{8}$ Текущий гоА является, по сути, последней проверкой переА началом нового этапа в развитии ETS EC. Острая необходимость такого реформирования подтвержАается и результатами исслеАований, проводимых уже несколько лет немецкими организациями New Climate Institute ${ }^{9}$ и Germanwatch $^{10}$, а также международной сетью Climate Action Network ${ }^{11}$. На основе их данных ежегодно составляется рейтинг эффективности национальных мер против изменения

\footnotetext{
6 Участие было обязательным Аля всех электростанций, которые потребляли больше 20 МВт.ч, включая обычные электростанции.

7 В перечень регулируемых операторов и установок были включены: нефтеперерабатывающие заводы, коксовые печи, метамургические заводы и заводы, производящие цемент, стекло, известь, кирпич, керамику, цемююлозу и бумагу.

8 Revision for phase 4 (2021-2030). URL: https://ec.europa.eu/clima/policies/ets/revision_en\#tab-0-0.

9 Организация, занимающаяся исследованиями в области климатической политики, глобальной устойчивости, изменения климата. URL: https://newclimate.org/.

10 Некоммерческая неправительственная организация, оказывающая влияние на государственную политику Германии в области торговли, окружающей среды и отношений между странами. URL: https://germanwatch. org.

${ }^{11}$ Глобальная сеть, включающая более 1300 экологических неправительственных организаций из 130 стран, главной целью которой является продвижение действий правительства и отдельных лиц по ограничению антропогенного изменения климата и Аостижения устойчивого уровня экологического состояния. URL: http:// www.climatenetwork.org/.
} 
климата - Climate Change Performance Index (CCPI). В 2019 г., как и в предыдущие годы, ни одна из стран не смогла набрать баммы, чтобы занять мидирующие места в Аанном инАексе. Вот уже несколько лет, включая 2019 г., три первых места в рейтинге остаются свободными, поскольку пока еще ни одна страна не сделала достаточно Аля Аостижения целей климатического соглашения. Перечень стран ЕС с указанием их места в рейтинге в 2006, 2008, 2012 и 2019 гг. и совокупной оценки в 2019 г. приведен в табл. 1.

Таблица 1

\section{Аинамика места стран - членов ЕС}

в Climate Change Performance Index в 2019, 2012, 2008 и 2006 гr. /

The dynamics of the place of EU member states

in the Climate Change Performance Index in 2019, 2012, 2008 and 2006

\begin{tabular}{|c|c|c|c|c|c|}
\hline $\begin{array}{c}\text { Совокупная } \\
\text { оценка } \\
\text { CСРІ } 2019\end{array}$ & Страна & $\begin{array}{c}\text { Место } \\
\text { в рейтинге } \\
\text { CСРI } 2019 \\
\end{array}$ & $\begin{array}{c}\text { Место } \\
\text { в рейтинге } \\
\text { CСРІ } 2012 \\
\end{array}$ & $\begin{array}{c}\text { Место } \\
\text { в рейтинге } \\
\text { CСРІ } 2008 \\
\end{array}$ & $\begin{array}{c}\text { Место } \\
\text { в рейтинге } \\
\text { CСРІ } 2006 \\
\end{array}$ \\
\hline 55.82 & ЕС (28 стран) & 22 & - & - & - \\
\hline 75.77 & Швеция & 4 & 4 & 1 & 7 \\
\hline 71.14 & Аания & 5 & 12 & 17 & 14 \\
\hline 69.80 & Великобритания & 7 & 5 & 7 & 3 \\
\hline 66.22 & Аитва & 8 & 16 & 20 & 4 \\
\hline 63.25 & ФИНАЯНАИЯ & 10 & 37 & 36 & 33 \\
\hline 60.91 & Аюксембург & 13 & 31 & 52 & 44 \\
\hline 60.75 & Аатвия & 15 & 22 & 11 & 2 \\
\hline 60.61 & Швейцария & 16 & 9 & 9 & 12 \\
\hline 57.90 & Франция & 18 & 8 & 18 & 11 \\
\hline 56.97 & Хорватия & 20 & 53 & 32 & 26 \\
\hline 55.78 & Германия & 23 & 6 & 2 & 5 \\
\hline 54.85 & Румыния & 24 & 28 & 27 & 20 \\
\hline 54.10 & Португалия & 25 & 14 & 13 & 25 \\
\hline 53.92 & Италия & 26 & 30 & 41 & 38 \\
\hline 52.69 & Словакия & 27 & 11 & 19 & 18 \\
\hline 52.59 & Греция & 28 & 47 & 43 & 40 \\
\hline 50.89 & Нилерланды & 29 & 42 & 30 & 15 \\
\hline 48.05 & Эстония & 31 & 40 & 35 & 32 \\
\hline 46.03 & Испания & 34 & 35 & 29 & 43 \\
\hline 45.73 & Бельгия & 35 & 13 & 12 & 19 \\
\hline 44.74 & Австрия & 38 & 34 & 37 & 28 \\
\hline 44.04 & ИрланАия & 41 & 17 & 44 & 39 \\
\hline 42.93 & Чехия & 43 & 46 & 25 & 41 \\
\hline 41.91 & Словения & 44 & 29 & 34 & 23 \\
\hline 41.66 & Кипр & 45 & 36 & 45 & H.A. \\
\hline 41.17 & Венгрия & 47 & 18 & 6 & 13 \\
\hline 40.12 & Болгария & 49 & 44 & 22 & 17 \\
\hline 39.98 & Польша & 50 & 56 & 39 & 21 \\
\hline
\end{tabular}

Источник: составлено авторами по ежегодным публикациям Germanwatch's Climate Change Efficiency Index Annual за 2019, 2012, 2008 и 2006 гr. / Source: compiled by the author on the Germanwatch's Climate Change Efficiency Index Annual Reports for 2019, 2012, 2008 and 2006.

Как виАно из табл. 1, только Аевять стран ЕС из 28 улучшили свои позиции в 2019 г. по сравнению с 2008 и 2006 гг. по индексу эффективности изменения климата. У остальных стран позиция ухудшилась. Это свидетельствует о наличии ряда противоречий и недостатков в функционировании механизма торговли разрешениями на выбросы $\mathrm{CO}_{2}$ и практическом регулировании выбросов $\mathrm{CO}_{2}$. 


\section{ВЫВОАЫ}

Краткий анализ сущности, особенностей применения, сильных и слабых сторон, проблем и препятствий в реализации механизма торговли разрешениями на выбросы $\mathrm{CO}_{2}$ позвомил саелать следующий вывоА. Механизм торговли разрешениями на выбросы $\mathrm{CO}_{2}$ может оказаться Аостаточно эффективным инструментом регулирования объемов выбросов в атмосферу. ОАнако вслеАствие существования серьезных недостатков и продолжающегося влияния ряда проблем в Аействии ETS EC к настоящему времени сложилась такая ситуация, что уже много лет ни одна из стран не может реализовать усилия по улучшению климата и добиться весомых положительных результатов.

Исследование показало, что улучшить функционирование ETS EC можно за счет соблюАения ряда условий:

- наличие достоверной информации по каждому предприятию о ежегодных выбросах парниковых газов, так как в настоящее время квота чаще всего Аается исходя из фактического объема выбросов в предыдущие годы;

- экономически обоснованное установление цены на квоты и мицензии;

- обеспечение более свободного рынка продажи прав на загрязнение;

- разработка четких и прозрачных правил продажи прав (квот) Аля всех субъектов углеродного рынка, при этом государственные служащие (инспекторы) Аолжны иметь возможность быстрого и полного контроля за их соблюАением;

- создание ограничений Аля оппортунистического поведения самих фирм-загрязнителей как до покупки мицензии (честность в определении объема выбросов и добровольность взятых на себя обязательств по сокращению выбросов), так и после ее покупки (отсутствие желания у фирм обойти требование о сокращении выбросов в тех объемах, которые предполагало правительство).

В целом, поскольку в настоящее время доминируют монетарные идеи улучшения климата, выполнение перечисленных требований, возможно, обеспечит хотя бы некоторое повышение эффективности функционирования принятой мировым сообществом системы торговли квотами на выбросы не только в рамках Европейского союза, но и в Аругих регионах мира.

\section{Список источников}

Ambec S., Cohen M., Elgie S. et al. The Porter Hypothesis at 20: Can Environmental Regulation Enhance Innovation and Competitiveness? // Review of Environmental Economics and Policy. 2013. Vol. 7 (1). P. 2-22.

Aus dem Moore N., Großkurth P., Themann M. Multinational corporations and the EU Emissions Trading System: the specter of asset erosion and creeping deindustrialization // Journal of Environmental Economics and Management. 2019. Vol. 94. P. 1-26.

Baranzini A., van den Bergh J. C. J. M., Carattini S. et al. Carbon pricing in climate policy: seven reasons, complementary instruments, and political economy considerations // WIREs Climate Change. 2017. Vol. 8. Iss. 4. P. 1-17. URL: https://doi.org/10.1002/wcc.462.

Bernardini E., Di Giampaolo J., Faiella I. et al. The impact of carbon risk on stock returns: Evidence form the European electric utilities // Journal of Sustainable Finance and Investment. 2019. URL: https://doi.org/10.1080/ 20430795.2019.1569445.

Borghesi S., Montini M. The Best (and Worst) of GHG Emission Trading Systems: Comparing the EU ETS with Its Followers // Frontiers in Energy Research. 2016. Vol. 4. URL: https://doi.org/10.3389/fenrg.2016.00027.

Branger F., Quirion P. Would border carbon adjustments prevent carbon leakage and heavy industry competitiveness losses? Insights from a meta-analysis of recent economic studies // Ecological Economics. 2014. Vol. 99. P. 29-39.

Branger F., Quirion P., Chevallier J. Carbon Leakage and Competitiveness of Cement and Steel Industries Under the EU ETS: Much Ado About Nothing // The Energy Journal. 2016. Vol. 37. № 3. P. 109-135.

Brannlund R., Lundgren T. Environmental Policy Without Costs? A Review of the Porter Hypothesis // International Review of Environmental and Resource Economics. 2009. Vol. 3. № 2. P. 75-117. URL: https://doi. org/10.1561/101.00000020. 


\section{Европейский опыт торговли разрешениями на выбросы}

Bryant G. The Politics of Carbon Market Design: Rethinking the Techno-politics and Post-politics of Climate Change // Antipode. 2016. Vol. 48. Iss. 4. P. 877-898. URL: https://doi.org/10.1111/anti.12237.

Buhr K., Roth S., Stigson P. Climate Change Politics through a Global Pledge-and-Review Regime: Positions among Negotiators and Stakeholders // Sustainability. 2014. Vol. 6. P. 794-811. URL: https://doi.org/10.3390/ su6020794.

Cadez S., Czerny A., Letmathe P. Stakeholder pressures and corporate climate change mitigation strategies // Business Strategy and the Environment. 2019. Vol. 28. Iss. 1. P. 1-14. URL: https://doi.org/10.1002/bse.2070.

Costantini V., Mazzanti M. On the green and innovative side of trade competitiveness? The impact of environmental policies and innovation on EU exports // Research Policy. 2012. Vol. 41. Iss. 1. P. $132-153$. URL: https://doi.org/10.1016/j.respol.2011.08.004.

de Bruyn S., Vergeer R., Schep E. et al. Ex-post investigation of cost pass-through in the EU ETS - an analysis for six sectors / Report for the European Commission. CE Delft and Oeko-Institut, 2015.

Dechezleprêtre A., Sato M. The Impacts of Environmental Regulations on Competitiveness // Review of Environmental Economics and Policy. 2017. Vol. 11. Iss. 2. P. 183-206. URL: https://doi.org/10.1093/reep/rey027.

Dechezleprêtre A., Gennaioli C., Martin R. et al. Searching for Carbon Leaks in Multinational Companies / CEP Discussion Paper № 1601, 2019. Centre for Economic Performance, London School of Economics and Political Science.

Dechezleprêtre A., Nachtigall D., Venmans F. The Joint Impact of the European Union Emissions Trading System on Carbon Emissions and Economic Performance / OECD Economics Department Working Papers 1515. Paris: OECD Publishing, 2018.

Ellerman A. D., Marcantonini C., Zaklan A. The European Union Emissions Trading System: Ten Years and Counting // Review of Environmental Economics and Policy. 2016. Vol. 10. Iss. 1. P. 89-107. URL: https://doi. org/10.1093/reep/rev014.

Ellerman A. D., Convery F., de Perthuis C. Pricing Carbon - The European Union Emissions Trading Scheme. Cambridge: Cambridge University Press, 2010.

Elsayed K., Paton D. The impact of environmental performance on firm performance: static and dynamic panel data evidence // Structural Change and Economic Dynamics. 2005. Vol. 16. Iss. 3. P. 395-412. URL: https:// doi.org/10.1016/j.strueco.2004.04.004.

Grether J.-M., Mathys N. A., de Melo J. Unravelling the worldwide pollution haven effect // The Journal of International Trade \& Economic Development. 2012. Vol. 21. Iss. 1. P. 131-162. URL: https://doi.org/10.1080/ 09638190903552040.

Hintermann B., Peterson S., Rickels W. Price and Market Behavior in Phase II of the EU ETS: A Review of the Literature // Review of Environmental Economics and Policy. 2016. Vol. 10. Iss. 1. P. 108-128. URL: https://doi. org/10.1093/reep/rev015.

Joltreau E., Sommerfeld K. Why does emissions trading under the EU Emissions Trading System not affect firms' competitiveness? Empirical findings from the literature // Climate Policy. 2019. Vol. 19. Iss. 4. P. 453-471. URL: https://doi.org/10.1080/14693062.2018.1502145.

Klemetsen M. E., Rosendahl K. E., Jacobsen A. L. The impacts of the EU ETS on Norwegian plants' environmental and economic performance / NMBU Working Paper 3/2016. Norwegian University of Life Sciences, School of Economics and Business, 2016.

Koch N., Mama H. B. Does the EU Emissions Trading System induce investment leakage? Evidence from German multinational firms // Energy Economics. 2019. Vol. 81. P. 479-492. URL: https://doi.org/10.1016/ j.eneco.2019.04.018.

Laing T., Sato M., Grubb M. et al. The effects and side-effects of the EU emissions trading scheme // Climate Change. 2014. Vol. 5 (4). P. 509-519.

Lopez-Gamero M. D., Molina-Azorín J. F., Clear-Cortes E. The whole relationship between environmental variables and firm performance: competitive advantage and firm resources as mediator variables // Journal of Environmental Management. 2009. Vol. 90. P. 3110-3121.

Löschel A., Lutz B., Managi S. The impacts of the EU ETS on efficiency and economic performance - an empirical analysis for German manufacturing firms // Resource and Energy Economics. 2019. Vol. 56. P. 71-95. URL: https:// doi.org/10.1016/j.reseneeco.2018.03.001.

Lundgren T., Marklund P. O., Samakovlis E. et al. Carbon prices and incentives for technological development // Journal of Environmental Management. 2015. Vol. 150. P. 393-403. URL: https://doi.org/10.1016/j.jenvman. 2014.12.015.

Marin G., Marino M., Pellegrin C. The Impact of the European Emission Trading Scheme on Multiple Measures of Economic Performance // Environmental and Resource Economics. 2018. Vol. 71. P. 551-582. URL: https:// doi.org/10.1007/s10640-017-0173-0.

Martin R., Muûls M., Wagner U. J. The Impact of the European Union Emissions Trading Scheme on Regulated Firms: What is the Evidence after Ten Years? // Review of Environmental Economics and Policy. 2016. Vol. 10. Iss. 1. P. 129-148. URL: https://doi.org/10.1093/reep/rev016.

Molina-Azorín J. F., Claver-Cortes E., Pereira-Moliner J. et al. Environmental practices and firm performance: an empirical analysis in the Spanish hotel industry // Journal of Cleaner Production. 2009. Vol. 17. Iss. 5. P. 516-524. URL: https://doi.org/10.1016/j.jclepro.2008.09.001. 
Muûls M., Colmer J., Martin R. et al. Evaluating the EU Emissions Trading System: Take it or Leave it? An Assessment of the Data after Ten Years / Grantham Institute Briefing paper No 21. London: Imperial College, 2016.

Naegele H., Zaklan A. Does the EU ETS cause carbon leakage in European manufacturing? // Journal of Environmental Economics and Management. 2019. Vol. 93. P. 125-147. URL: https://doi.org/10.1016/j.jeem. 2018.11.004.

Pereira da Silva P., Moreno B., Figueiredo N. C. Firm-specific impacts of $\mathrm{CO}_{2}$ prices on the stock market value of the Spanish power industry // Energy Policy. 2016. Vol. 94. P. 492-501. URL: https://doi.org/10.1016/j.enpol. 2016.01.005.

Reinaud J. Climate Policy and Carbon Leakage: Impacts of the European Emissions Trading Scheme on Aluminium / IEA Information Paper. OECD/IEA, 2008.

Sarkis J., Cordeiro J. J. An empirical evaluation of environmental efficiencies and firm performance: pollution prevention versus end-of-pipe practice // European Journal of Operational Research. 2001. Vol. 135 (1). P. $102-113$.

Sartor O. Carbon leakage in the primary aluminium sector: what evidence after $61 / 2$ years of the EU ETS? / CDC Climat Research Working Paper No 2012-12.

Segura S., Ferruz L., Gargallo P. et al. Environmental versus economic performance in the EU ETS from the point of view of policy makers: A statistical analysis based on copulas // Journal of Cleaner Production. 2018. Vol. 176. P. 1111-1132. URL: https://doi.org/10.1016/j.jclepro.2017.11.218.

Stavins R. N. Experience with Market-Based Environmental Policy Instruments. Discussion Paper 01-58. Washington, D.C.: Resources for the Future, 2001.

Tian Y., Akimov A., Roca E. et al. Does the carbon market help or hurt the stock price of electricity companies? Further evidence from the European context // Journal of Cleaner Production. 2016. Vol. 112. P. 2. 1619-1626. URL: https://doi.org/10.1016/j.jclepro.2015.07.028.

Verde S. F. The Impact of the EU Emissions Trading System on Competitiveness and Carbon Leakage: the Econometric Evidence // Journal of Economic Surveys. 2020. Vol. 34. Iss. 2. P. 320-343. URL: https://doi.org/ 10.1111/joes.12356.

$\mathrm{Yu} \mathrm{H}$. The EU ETS and firm profits: and ex-post analysis for Swedish energy firms // Environmental Economics. 2013. Vol. 4 (3). P. 59-71.

Поступила в редакцию 14 июля 2020 г. Принята к публикации 19 августа 2020 г.

\section{References}

Ambec S., Cohen M., Elgie S. et al. (2013). The Porter Hypothesis at 20: Can Environmental Regulation Enhance Innovation and Competitiveness? Review of Environmental Economics and Policy, vol. 7, no. 1, pp. 2-22.

Aus dem Moore N., Großkurth P., Themann M. (2019). Multinational corporations and the EU emissions trading system: the specter of asset erosion and creeping deindustrialization. Journal of Environmental Economics and Management, vol. 94, pp. 1-26.

Baranzini A., van den Bergh J.C.J.M., Carattin, S. et al. (2017). Carbon pricing in climate policy: seven reasons, complementary instruments, and political economy considerations. WIREs Climate Change, vol. 8, iss. 4, pp. 1-17. Available at: https://doi.org/10.1002/wcc.462

Bernardini E., Di Giampaolo J., Faiella I. et al. (2019). The impact of carbon risk on stock returns: evidence form the European electric utilities. Journal of Sustainable Finance and Investment. Available at: https://doi.org/ 10.1080/20430795.2019.1569445.

Borghesi S., Montini M. (2016). The Best (and Worst) of GHG Emission Trading Systems: Comparing the EU ETS with Its Followers. Frontiers in Energy Research, vol. 4, no. 27. Available at: https://doi.org/10.3389/fenrg.2016. 00027.

Branger F., Quirion P. (2014). Would border carbon adjustments prevent carbon leakage and heavy industry competitiveness losses? Insights from a meta-analysis of recent economic studies. Ecological Economics, vol. 99, pp. 29-39

Branger F., Quirion P., Chevallier J. (2016). Carbon Leakage and Competitiveness of Cement and Steel Industries Under the EU ETS: Much Ado About Nothing. The Energy Journal, vol. 37, no. 3, pp. 109-135.

Brannlund R., Lundgren T. (2009). Environmental Policy Without Costs? A Review of the Porter Hypothesis. International Review of Environmental and Resource Economics, vol. 3, iss. 2, pp. 75-117. Available at: https:// doi.org/10.1561/101.00000020.

Bryant G. (2016). The Politics of Carbon Market Design: Rethinking the Techno-politics and Post-politics of Climate Change. Antipode, vol. 48, no. 4, pp. 877-898. Available at: https://doi.org/10.1111/anti.12237.

Buhr K., Roth S., Stigson P. (2014). Climate Change Politics through a Global Pledge-and-Review Regime: Positions among Negotiators and Stakeholders. Sustainability, vol. 6, pp. 794-811. Available at: https://doi. org/10.3390/su6020794. 


\section{Европейский опыт торговли разрешениями на выбросы}

Cadez S., Czerny A., Letmathe P. (2019). Stakeholder pressures and corporate climate change mitigation strategies. Business Strategy and the Environment, vol. 28, iss. 1, pp. 1-14. Available at: https://doi.org/10.1002/bse.2070.

Costantini V., Mazzanti M. (2012). On the green and innovative side of trade competitiveness? The impact of environmental policies and innovation on EU exports. Research Policy, vol. 41, iss. 1, pp. 132-153. Available at: https://doi.org/10.1016/j.respol.2011.08.004.

de Bruyn S., Vergeer R., Schep E. et al. (2015). Ex-post investigation of cost pass-through in the EU ETS an analysis for six sectors. Report for the European Commission, CE Delft and Oeko-Institut.

Dechezleprêtre A., Sato M. (2017). The impacts of environmental regulations on competitiveness. Review of Environmental Economics and Policy, vol. 11, no. 2, pp. 183-206. Available at: https://doi.org/10.1093/reep/ rey027.

Dechezleprêtre A., Gennaioli C., Martin R. et al. (2019). Searching for Carbon Leaks in Multinational Companies. CEP Discussion Paper 1601. Centre for Economic Performance, London School of Economics and Political Science.

Dechezleprêtre A., Nachtigall D., Venmans F. (2018). The Joint Impact of the European Union Emissions Trading System on Carbon Emissions and Economic Performance. OECD Economics Department Working Papers 1515, Paris: OECD Publishing.

Ellerman A.D., Marcantonini C., Zaklan A. (2016). The European Union emissions trading system: ten years and counting. Review of Environmental Economics and Policy, vol. 10, no. 1, pp. 89-107. Available at: https://doi. org/10.1093/reep/rev014.

Ellerman A.D., Convery F., de Perthuis C. (2010). Pricing Carbon - The European Union Emissions Trading Scheme. Cambridge: Cambridge University Press.

Elsayed K., Paton D. (2004). The impact of environmental performance on firm performance: static and dynamic panel data evidence. Structural Change and Economic Dynamics, vol. 16, pp. 395-412. Available at: https://doi. org/10.1016/j.strueco.2004.04.004.

Grether J.-M., Mathys N.A., de Melo J. (2012). Unravelling the worldwide pollution haven effect. The Journal of International Trade and Economic Development, vol. 21, no. 1, pp. 131-162. Available at: https://doi. org/10.1080/09638190903552040.

Hinterman B., Peterson S., Rickels W. (2016). Price and market behavior in phase II of the EU ETS: a review of the literature. Review of Environmental Economics and Policy, vol. 10, no. 1, pp. 108-128. Available at: https:// doi.org/10.1093/reep/rev015.

Joltreau E., Sommerfeld K. (2019). Why does emissions trading under the EU Emissions Trading System not affect firms' competitiveness? Empirical findings from the literature. Climate Policy, vol. 19, no. 4, pp. 453-471. Available at: https://doi.org/10.1080/14693062.2018.1502145.

Klemetsen M.E., Rosendahl K.E., Jacobsen A.L. (2016). The impacts of the EU ETS on Norwegian plants' environmental and economic performance. NMBU Working Paper 3/2016, Norwegian University of Life Sciences School of Economics and Business.

Koch N., Mama H.B. (2019). Does the EU Emissions Trading System induce investment leakage? Evidence from German multinational firms. Energy Economics, vol. 81, pp. 479-492. Available at: https://doi.org/10.1016/ j.eneco.2019.04.018.

Laing T., Sato M., Grubb M. et al. (2014). The effects and side-effects of the EU emissions trading scheme. Climate Change, vol. 5, no. 4, pp. 509-519.

Lopez-Gamero M.D., Molina-Azorín J.F., Clear-Cortes E. (2009). The whole relationship between environmental variables and firm performance: competitive advantage and firm resources as mediator variables. Journal of Environmental Management, vol. 90, pp. 3110-3121.

Löschel A., Lutz B., Managi S. (2019). The impacts of the EU ETS on efficiency and economic performance an empirical analysis for German manufacturing firms. Resource and Energy Economics, vol. 56, pp. 71-95. Available at: https://doi.org/10.1016/j.reseneeco.2018.03.001.

Lundgren T., Marklund P.O., Samakovlis E. et al. (2015). Carbon prices and incentives for technological development. Journal of Environmental Management, vol. 150, pp. 393-403. Available at: https://doi.org/ 10.1016/j.jenvman.2014.12.015.

Marin G., Marino M., Pellegrin C. (2018). The impact of the European emission trading scheme on multiple measures of economic performance. Environmental and Resource Economics, vol. 71, pp. 551-582. Available at: https://doi.org/10.1007/s10640-017-0173-0.

Martin R., Muûls M., Wagner U.J. (2016). The impact of the European Union emissions trading Scheme on regulated firms: what is the evidence after ten years? Review of Environmental Economics and Policy, vol. 10, no. 1, pp. 129-148. Available at: https://doi.org/10.1093/reep/rev016.

Molina-Azorín J.F., Claver-Cortes E., Pereira-Moliner J. et al. (2009). Environmental practices and firm performance: an empirical analysis in the Spanish hotel industry. Journal of Cleaner Production, vol. 17, no. 5, pp. 516-524. Available at: https://doi.org/10.1016/j.jclepro.2008.09.001.

Muûls M., Colmer J., Martin R. et al. (2016). Evaluating the EU Emissions Trading System: Take it or Leave it? an Assessment of the Data after Ten Years. Grantham Institute Briefing paper No 21. Imperial College, London.

Naegele H., Zaklan A. (2019). Does the EU ETS cause carbon leakage in European manufacturing? Journal of Environmental Economics and Management, vol. 93, pp. 125-147. Available at: https://doi.org/10.1016/ j.jeem.2018.11.004. 
Pereira da Silva P., Moreno B., Figueiredo N.C. (2016). Firm-specific impacts of $\mathrm{CO}_{2}$ prices on the stock market value of the Spanish power industry. Energy Policy, vol. 94, pp. 492-501. Available at: https://doi.org/10.1016/ j.enpol.2016.01.005.

Reinaud J. (2008). Climate policy and carbon leakage: impacts of the European Emissions Trading Scheme on aluminium. IEA Information Paper, OECD/IEA, Paris, France.

Sarkis J., Cordeiro J.J. (2001). An empirical evaluation of environmental efficiencies and firm performance: pollution prevention versus end-of-pipe practice. European Journal of Operational Research, vol. 135, no. 1, pp. 102-113.

Sartor O. (2012). Carbon leakage in the primary aluminium sector: what evidence after 6.5 years of the EU ETS? CDC Climat Research Working Paper 2012-12, CDC Climat Research.

Segura S., Ferruz L., Gargallo P. et al. (2018). Environmental versus economic performance in the EU ETS from the point of view of policy makers: A statistical analysis based on copulas. Journal of Cleaner Production, vol. 176, pp. 1111-1132. Available at: https://doi.org/10.1016/j.jclepro.2017.11.218.

Stavins R.N. (2001). Experience with Market-Based Environmental Policy Instruments. Discussion Paper 01-58. Washington, D.C.: Resources for the Future, p. 2.

Tian Y., Akimov A., Roca E. et al. (2016). Does the carbon market help or hurt the stock price of electricity companies? Further evidence from the European context. Journal of Cleaner Production, vol. 112, pp. 1619-1626. Available at: https://doi.org/10.1016/j.jclepro.2015.07.028.

Verde S.F. (2020). The Impact of the EU Emissions Trading System on Competitiveness and Carbon Leakage: the Econometric Evidence. Journal of Economic Surveys, vol. 34, no. 2, pp. 320-343. Available at: https://doi. org/10.1111/joes.12356.

Yu H. (2013). The EU ETS and firm profits: and ex-post analysis for Swedish energy firms. Environmental Economics, vol. 4, no. 3, pp. 59-71.

Received 14.07.2020

Accepted for publication 19.08.2020 


\title{
"Зеленая" экономика как фактор производительности труда в обрабатывающей промышленности стран Европейского союза
}

\author{
Владислав Николаевич Руцкий, к. э. Н., Аоцент Института экономики, управле- \\ ния и природопользования Сибирского федерального университета, г. Красноярск \\ E-mail: rootskey.vn@gmail.com, ORCID 0000-0003-1020-590X \\ Мария Васимьевна Осипенко, учащаяся бакалавриата Института экономики, \\ управления и природопользования Сибирского федерального университета, \\ г. Красноярск \\ E-mail: mosipenko.sfu@gmail.com, ORCID 0000-0002-3953-8305
}

\begin{abstract}
Аннотация
Многие страны декларируют модель устойчивого развития и переход к "зеленой" экономике как один из важных приоритетов экономической политики, нацеленной на сбережение природных ресурсов и снижение антропогенной нагрузки на окружающую среду. ОАнако проблема оценки эффективности "зеленой" экономики и конкурентоспособности связанных с ней технологий все еще остается открытым вопросом. Статья посвящена изучению подходов к измерению “зеленой" экономики, эмпирическому анализу взаимосвязи производительности труда в обрабатывающей промышленности и факторов формирования "зеленой" экономики Аля ряда стран Европейского союза, характеризующихся высокими показателями в глобальных рейтингах “зеленой" экономики. Изучая подходы к илентификации и измерению "зеленой" экономики, авторы выявляют тенденции формирования новой модели экологически устойчивого развития в странах Европейского союза и динамику ключевых показателей "зеленой" экономики. В статье разрабатывается эмпирическая корреляционно-регрессионная модель, которая описывает наряду с Аругими факторами влияние факторов "зеленой" экономики на производительность труда в обрабатывающей промышленности. Оценка спецификации модели по панельным данным отрасли обрабатывающей промышленности семи стран Европейского союза показывает в целом значимый положительный эффект инвестиций в оборудование и установки Аля борьбы с загрязнением на производительность труАа в отрасли, что говорит о целесообразности Аальнейших исследований, в частности, о возможной привлекательности частных инвестиций в формирование "зеленой" экономики в различных отраслях экономики как развитых, так и развивающихся стран.
\end{abstract}

Ключевые слова: "зеленая" экономика, производительность труда, устойчивое развитие, госуАарственная подАержка, инвестиции в "зеленые» технологии, эмпирическая модель, отраслевые данные

JEL: 044, Q56, C33

Аия цитирования: Руцкий В. Н., Осипенко М. В. “Зеленая" экономика как фактор производительности труда в обрабатывающей промышленности стран Европейского союза // Финансовый журнал. 2020. T. 12. № 4. C. 69-84. DOI: 10.31107/2075-1990-2020-4-69-84. 
DOI: 10.31107/2075-1990-2020-4-69-84

\title{
Green Economy as a Labor Productivity Factor in the Manufacturing Industry of European Union Countries
}

\author{
Vladislav N. Rutskiy ${ }^{1}$ \\ E-mail: rootskey.vn@gmail.com, ORCID 0000-0003-1020-590X \\ Maria V. Osipenko ${ }^{1}$ \\ E-mail: mosipenko.sfu@gmail.com, ORCID 0000-0002-3953-8305 \\ ${ }^{1}$ Siberian Federal University, Krasnoyarsk 660041, Russian Federation
}

\begin{abstract}
These days many countries declare saving natural resources and reducing anthropogenic pressure on the environment as being among their national priorities. They place importance on sustainable development and the transition to a green economy model. However, the problem of assessing the effectiveness of the green economy and the competitiveness of related technologies is still open to debate. The paper examines approaches to measuring the green economy and presents an empirical analysis of the relationship between labor productivity in the manufacturing industry and green economy factors for a number of European Union countries, characterized by high performance in the global rankings of the green economy. Studying approaches to the identification and measurement of the green economy, the authors identify trends in the realization of a new environmentally sustainable development model in the countries of the European Union and the dynamics of key indicators of the green economy. The paper develops an empirical correlation and regression model that defines, along with other factors, the influence of green economy factors on labor productivity in manufacturing. An assessment of the model specification based on panel data from the manufacturing industries of seven European countries shows a significant positive effect of investment in equipment and plant for pollution control on labor productivity in the industry. The results indicate the relevance of further studies, in particular, the possible attractiveness of private investment in the formation of a green economy in various sectors of the economy in both developed and developing countries.
\end{abstract}

Keywords: green economy, labor productivity, sustainable development, government support, investments in green technology, empirical model, industrial data

JEL: 044, Q56, C33

For citation: Rutskiy V.N., Osipenko M.V. Green Economy as a Labor Productivity Factor in the Manufacturing Industry of European Union Countries. Financial Journal, 2020, vol. 12, no. 4, pp. 69-84 (In Russ.). DOI: 10.31107/2075-1990-2020-4-69-84.

\section{BBEAEHИE}

Несмотря на заявления о необходимости перехода к модели "устойчивого развития", то есть стабилизации антропогенной нагрузки на окружающую среАу, которые звучат от лица правительств многих развитых и развивающихся стран на протяжении последних десятилетий, в современном мире существует множество экологических проблем, которые требуют незамеАлительных действий, в том числе высокие экологические изАержки экономического роста и угроза изменения климата, препятствующие прогрессу. Среди межАународного сообщества становится популярной идея перехода к новой модели развития экономики, "зеленой" экономике, которая опирается на управляемую синергию межАу интенсивным экономическим ростом, социальной интеграцией и сохранением окружающей среды. В связи с этим актуально исследование экономических последствий такой политики, в особенности количественного измерения ее эмпирической эффективности как на макроуровне, так и на отраслевом уровне, что важно Аля выявления возможных источников ее финансирования. 
В экономической митературе существуют Аве противоположные точки зрения на взаимосвязь политики формирования "зеленой" экономики и производительности труда в экономике. Традиционный поАХоА рассматривает природоохранную политику как бремя Аля экономической деятельности, по крайней мере в краткосрочной и среднесрочной перспективе, поскольку она повышает затраты без увеличения объема производства и ограничивает набор технологий производства и результатов.

Например, в ряде исследований была предпринята попытка объяснить значительную часть снижения производительности труда в Соединенных Штатах в 1970-х гг. возрастающей ролью экологической политики [Christainsen G. B., Haveman R. H., 1981]. Э. Аенисон, проведя эконометрическое исследование частного сектора, показывает, что 16 \% снижения роста производительности может быть связано с экологическими нормами [Denison E. F., 1979]. С. Иссуфу и Н. Уаттара провели регрессионный анализ африканских стран и пришли к выводу, что "зеленые" инвестиции наносят ущерб росту произвоАительности, и утвержАают, что африканские страны должны быть осторожны в принятии "зеленых" технологий [Issoufou S., Ouattara N., 2011]. Также такие ученые, как Ф. Гомлоп и М. Робертс, С. Аюфур и соавторы утвержАают, что экологическое регулирование снижает производительность труда из-за снижения эффективности затрат, связанного с исполнением экологических норм [Gollop F. M., Roberts M. J., 1983; Dufour C. et al., 1998].

С Аругой стороны, в начале 1990-х гг. М. Портер предположил, что «зеленые" инвестиции повышают конкурентоспособность и прибыльность фирмы посредством процесса модернизации, социально ответственного имиджа, доступа к новым рынкам и сокращения расточительных практик [Porter М., 1991]. Портер и Аинде считают, что фирмы, инвестирующие в «зеленые" технологии, повышают свою международную конкурентоспособность [Porter M., van der Linde C., 1995]. Это Аостигается за счет необходимых инноваций, которые создают эффективные способы производства и, слеАовательно, повышают производительность.

Так, С. Альбризио провела эмпирический анализ на уровне фирм и отраслей и пришла к выводу, что ужесточение экологической политики ведет к краткосрочному повышению производительности труда на уровне отрасли в большинстве технологически развитых стран. Этот эффект уменьшается в менее развитых странах. Аля среАней фирмы никаких доказательств гипотезы Портера, согласно которой строгие экологические нормы могут повышать эффективность и стимулировать инновации и, как слеАствие, повысить коммерческую конкурентоспособность, не найдено. Тем не менее в технологически проАвинутых фирмах и отраслях, как правило, наблюдается временное ускорение роста производительности, в то время как технологически отстающие в этом плане проигрывают [Albrizio S. et al., 2017].

Кроме того, Н. Амара и Аругие в своем исследовании сельскохозяйственного сектора находят положительную связь межАУ эффективными методами произвоАства и принятием экологически чистых методов производства, что ведет к снижению загрязнения воды и деградации почвы [Amara N. et al., 1999]. Р. ^ин и Ч. Шеу доказали, что практика "зеленой" цепочки поставок, "зеленая" сертификация и "зеленые" прямые инвестиции повышают производственные показатели [Lin R., Sheu C., 2012]. Более того, они подтвердили, что институциональные силы влияют на распространение практики "зеленой" цепочки поставок.

На европейских предприятиях обрабатывающей промышленности практика внедрения "зеленых" технологий в производство распространена уже несколько Аесятилетий. В Германии еще в конце 1980-х - начале 1990-х гг. возникла концепция "зеленого" производства. Как отмечают Рехман и Шривастава, экологические нормы и общественное Аавление в сочетании с экономическими и технологическими факторами оказали влияние на становление во всем мире более экологически ответственной и "зеленой" промышленности [Rehman M. A. A., Shrivastava R. L., 2013]. 
В связи с вышеупомянутой Аискуссией в литературе мы поставили целью настоящего исследования обнаружение эмпирической взаимосвязи между факторами "зеленой" экономики и производительности труда на примере обрабатывающей промышленности в ряде стран Европейского союза, Аля которых характерно применение инструментов стимулирования развития "зеленой" экономики.

Исходя из поставленной цели исследования, в первую очереАь изучим поАходы к идентификации "зеленой" экономики и ее измерению, прослеАим тенденции ее формирования в странах Европейского союза, определим набор ключевых факторов Аля анализа "зеленой" экономики в странах Европейского союза и в итоге построим корремяционно-регрессионную модель взаимосвязи факторов производительности труда в обрабатывающей промышленности ряда выбранных стран, в том числе факторов “зеленой» экономики.

\section{ПРОБАЕМЫ ИАЕНТИФИКАЦИИ “ЗЕАЕНОЙ" ЭКОНОМИКИ}

Термин «зеленая" экономика был впервые сформулирован в работе «Проект зеленой экономики", которая стала основой Аля формирования Аанной концепции [Pearce D. et al., 1989]. За последние Ава десятилетия концепции "зеленой" экономики и "зеленого" роста получили большое распространение в политических программах на национальном и глобальном уровнях. Многие правительства и неправительственные организации разработали планы действий и внеАрили политику “зеленой" экономики в таких секторах, как энергетика, транспорт, сельское хозяйство и т. А.

ОАнако парамлельно с расширением сферы применения Аанные понятия становятся все более неоднозначными и противоречивыми [Georgeson L. et al., 2017]. Аоклал Европейского агентства по окружающей среде (EEA) обращает внимание на множественность интерпретаций термина "зеленая" экономика, которая может привести к размыванию концепции как в научном, так и в прикладном аспектах ${ }^{1}$.

Конференция ООН по торговле и развитию и Программа ООН по окружающей среАе понимают поА "зеленой" экономикой сферу, которая способствует социальной справеАливости, повышению благосостояния населения, снижению различных рисков Аля окружающей среды и сокращению экологических дефицитов ${ }^{2}$. Аанное определение стало наиболее широко применяемым и авторитетным из всех существующих. ЗАесь "зеленая" экономика изображается как способ улучшить окружающую среду и снизить вредное возАействие на нее. Она также может способствовать росту экономики, одновременно Аелая ее более социально ориентированной [Borel-Saladin J. M., Turok I. N., 2013]. Tак, это определение охватывает три аспекта устойчивого развития: экологическое, социальное и экономическое.

Организация экономического сотрудничества и развития (ОЭСР) Аала следующее определение термину: «Зеленый рост означает стимулирование экономического роста и развития, обеспечивая при этом сохранность природных активов и бесперебойное предоставление ими ресурсов и экосистемных услуг, от которых зависит наше благополучие» ${ }^{3}$.

Группа Green Economy Coalition определяет “зеленую” экономику так: “Экономика, которая обеспечивает мучшее качество жизни для всех в пределах экологических границ планеты» [Hopkins C., 2017]. Этот подход обращает внимание на «зеленую" экономику как на механизм роста благосостояния и повышения качества природного капитала.

1 Оценка оценок окружающей среды Европы / Европейское агентство по окружающей среде, 2011.

2 The Green Economy: Trade and Sustainable Development Implications / The United Nations Conference on Trade and Development, 2011.

3 Курс на зеленый рост. Резюме Аля лиц, принимающих решения / ОЭСР, май 2011, с. 4. 
Международная торговая палата дает определение термину «зеленая" экономика в первую очередь с точки зрения бизнеса - как «экономики, в которой экономический рост и ответственность за состояние окружающей среды взаимодействуют Аруг с Аругом, подАерживая прогресс и социальное развитие»"

Таким образом, определения "зеленой" экономики и "зеленого" роста могут различаться, но их ключевые элементы периодически повторяются. Основное внимание в "зеленой" экономике уделяется взаимосвязи межАу окружающей средой и экономикой, но при этом учитывается и социальный аспект.

Российские экономисты также отметили появление нового направления в экономической науке. Б. Н. Порфирьев отмечает, что достаточно широкое определение "зеленой" экономики экспертами ЮНЕП (Программа ООН по окружающей среАе) не позволяет существенно разграничить "зеленую" экономику и концепцию устойчивого развития. С его точки зрения, более целесообразно относить к "зеленой" экономике создание и применение специфических «чистых" и ресурсосберегающих технологий и производство соответствующего оборудования Аля контроля и сокращения загрязнений, а также Аля мониторинга и прогнозирования изменения климата [Порфирьев Б. Н., 2011].

С. Н. Бобылев и В. М. Захаров отмечают, что основное предназначение концепции "зеленой" экономики заключается в уходе от сырьевой модели развития экономики и росте ее энергоэффективности, обеспечении как чисто экономической, так и экологической эффективности производства путем снижения вредных выбросов и ресурсосбережения [Бобылев С. Н., Захаров В. М., 2012]. В. С. Бочко в своих работах выделил четыре основных подхода к определению "зеленой" экономики [Бочко В. С., 2014]: общеэкономический, отраслевой, технологический, цивилизационный, или нравственно-технологический. Хотя эти определения полезны Аля понимания концепции “зеленой" экономики, они малоприменимы Аля оценки эффективности “зеленых" технологий.

\section{ФОРМИРОВАНИЕ И ИЗМЕРЕНИЕ “ЗЕАЕНОЙ" ЭКОНОМИКИ В СТРАНАХ ЕВРОПЕЙСКОГО СОЮЗА}

Выбор показателей измерения "зеленой" экономики является одной из наиболее важных и в то же время оАной из наиболее трудных исследовательских задач, поскольку их Аостоверность, широта охвата и качество напрямую влияют на достоверность и применимость оценок эффективности "зеленой" экономики, в том числе Аля целей планирования и реализации соответствующей государственной политики.

Измерение Аолжно охватывать как оценку нынешнего состояния окружающей среды, так и внешние воздействия, возникающее в результате человеческой деятельности и политики правительства. Подобно набору показателей устойчивого развития, показатели "зеленой" экономики Аолжны не только Аавать хорошее преАставление об экономической, социальной и экологической сферах экономики, но и показывать взаимосвязи межАу ними.

Существующие показатели измерения "зеленой" экономики в научных исследованиях в основном базируются на подходах международных организаций. Так, ОЭСР преАлагает четыре группы характеристик «зеленого" роста:

1. экологическая и ресурсная продуктивность (измерение степени экологичности экономического роста при более эффективном использовании природного капитала);

2. база природных активов (измерение рисков Аля экономического роста в силу истощения запасов природных ресурсов);

3. экологическое измерение качества жизни (измерение воздействия условий окружающей среды на качество жизни и благосостояние населения);

${ }^{4}$ Roadmap for Green Growth / International Chamber of Commerce, 2012. URL: https://iccwbo.org/mediawall/news-speeches/international-chamber-of-commerce-releases-roadmap-for-green-growth/. 
4. экономические возможности и политические меры (измерение эффективности политики по обеспечению зеленого роста и описание общественных действий, необхоАимых Аля созАания возможностей Аля бизнеса и занятости) ${ }^{5}$.

ЮНЕП также разработала поАХоА к измерению Аостижений в "зеленой" экономической трансформации ${ }^{6}$. Помимо типичных социальных и экологических показателей ЮНЕП призывает измерять возАействия правительственной политики и инициатив на "зеленую" экономику. Список рекомендуемых показателей разделен на три основные категории. Первая категория вк^ючает индикаторы Аля оценки текущего состояния окружающей среАы, рисков и положительных тенденций, а также отслеживания прогресса в Аостижении конкретных экологических целей. Вторая включает показатели, используемые Аля оценки влияния правительственных инициатив и эффективности экономической политики, а в третью входят показатели влияния "зеленой" экономики на благосостояние кюАей и социальную справедливость.

Группа экологических показателей, рекомендованных ЮНЕП, охватывает четыре области: изменение климата, управление экосистемами, продуктивность и эффективность использования ресурсов, а также управление химическими веществами и отходами. К категории политических мер ЮНЕП относит пять основных областей: “зеленые» инвестиции, "зеленая" налоговая реформа, оценка внешних эффектов и оценка экосистемных услуг, «зеленые" закупки и обучение навыкам, необходимым для "зеленых" рабочих мест. Третья категория показателей имююстрирует влияние экономики на благосостояние Аюдей, зАоровье и качество жизни.

Статистическая служба Европейского союза разработала счета сектора экологических товаров и услуг, где приводятся Аанные о деятельности национальной экономики, в результате которой производится экологическая продукция. Счета облегчают мониторинг прогресса в реализации приоритетов политики Евросоюза в области охраны окружающей среды, управления ресурсами и зеленого роста.

Счета сектора экологических товаров и услуг включают в себя Аанные о выпуске, занятости, экспорте и добавленной стоимости, которая создается в ходе производства товаров и услуг. Эти Аанные используются Аля “измерения, предотвращения, ограничения, минимизации и устранения ущерба окружающей среде и рационального использования природных ресурсов" ${ }^{7}$. Аанная статистика является чрезвычайно полезной Аля анализа проблем, связанных с «зеленым" ростом и «зеленой" занятостью.

Политика стран Европейского союза активно направлена на снижение воздействия на окружающую среду. В 2014 г. Европейский совет одобрил основные направления реализации политики в сфере климата и энергетики с 2020 по 2030 г. $^{8}$ Они включают три цели: сокращение выбросов парниковых газов в европейских странах на 40 \% (к уровню 1990 г.), Аостижение Аоли возобновляемых источников энергии в энергобалансе европейских стран до уровня не менее $27 \%$, Аальнейшее повышение энергоэффективности экономик на 27 \% (по сравнению с т. н. сценарием business as usual).

K 2017 г. ЕС в целом сократил выбросы парниковых газов на 21,7 \% по сравнению с уровнем 1990 г. Все секторы, кроме транспортного, способствовали общему сокращению выбросов парниковых газов с 1990 по 2017 г. В абсолютном выражении наибольшее сокращение выбросов от сжигания топлива было в энергетических отраслях с сокращением на 496 млн т эквивалента $\mathrm{CO}_{2}$ за периол (-29,6 \%). Тем не менее энергетический

${ }^{5}$ OECD Green Growth Indicators Database documentation / OECD.stat. URL: https://stats.oecd.org/Index. aspx?DataSetCode=GREEN_GROWTH.

${ }^{6}$ Measuring Progress towards an Inclusive Green Economy / United Nations Environment Programme, 2012.

7 Environmental goods and services sector accounts handbook / Eurostat, 2016.

8 European Council (23 and 24 October 2014) Conclusions, EUCO 169/14 / Brussels: European Council, 2014. 
сектор по-прежнему несет ответственность за наибольшую долю общих выбросов (26,3 \% в 2017 г.). Второе по величине абсолютное сокращение было достигнуто в секторе обрабатывающей промышленности и строительстве с сокращением на 336 млн т эквивамента $\mathrm{CO}_{2}(-40,2 \%)^{9}$. ОАним из возможных факторов, способствующих снижению выбросов парниковых газов, стало увеличение национальных расходов на охрану окружающей среды на 22 \% с 2006 по 2018 г.

В периол с 2004 по 2018 г. Аоля возобновляемых источников энергии в Европейском союзе возросла более чем в Ава раза, Аостигнув 17,97 \% (что выше среднемирового значения 17,5 \% в 2016 г.) от общего конечного потребления энергии в 2018 г. (по Аанным Евростата $)^{10}$. Основными Авижущими силами этого роста стали быстрое развитие технологий, реализация схем подАержки технологий использования возобновляемых источников энергии (^ьготные тарифы, гранты, налоговые льготы, конкурсные торги, обязательные квоты и Ар.) и снижение затрат на системы возобновляемой энергии.

Исследования и разработки также важны Аля хорошо функционирующей экономики, основанной на знаниях, и конкурентоспособности промышленности. Они способствуют созАанию рабочих мест, росту производительности труда и более эффективному использованию ресурсов, играют ведущую роль в создании научных и технических продуктов, необходимых Аля решения глобальных социальных и экологических проблем, таких как изменение климата и чистая энергия.

Показатель "валовые внутренние расходы на НИОКР", также называемый интенсивностью НИОКР, преАставляет Аолю валового внутреннего продукта, предназначенную Аля исслеАований и разработок. Расходы стран Европейского союза на НИОКР превысили 2,0 \% ВВП в 2013 г. и с тех пор, по Аанным Евростата, находятся приблизительно на одном уровне. Таким образом, в ЕС не наблюдается значительного продвижения к цели в 3 \% по интенсивности исследований и разработок на 2020 г.

Рисунок 1

Ресурсная производительность в сравнении с ВВП и внутренним материальным потреблением, ЕC-27, 2000-2018 (Индекс 2000 = 100) / Resource productivity in comparison to GDP and DMC, EU-27, 2000-2018 (Index: 2000 = 100)

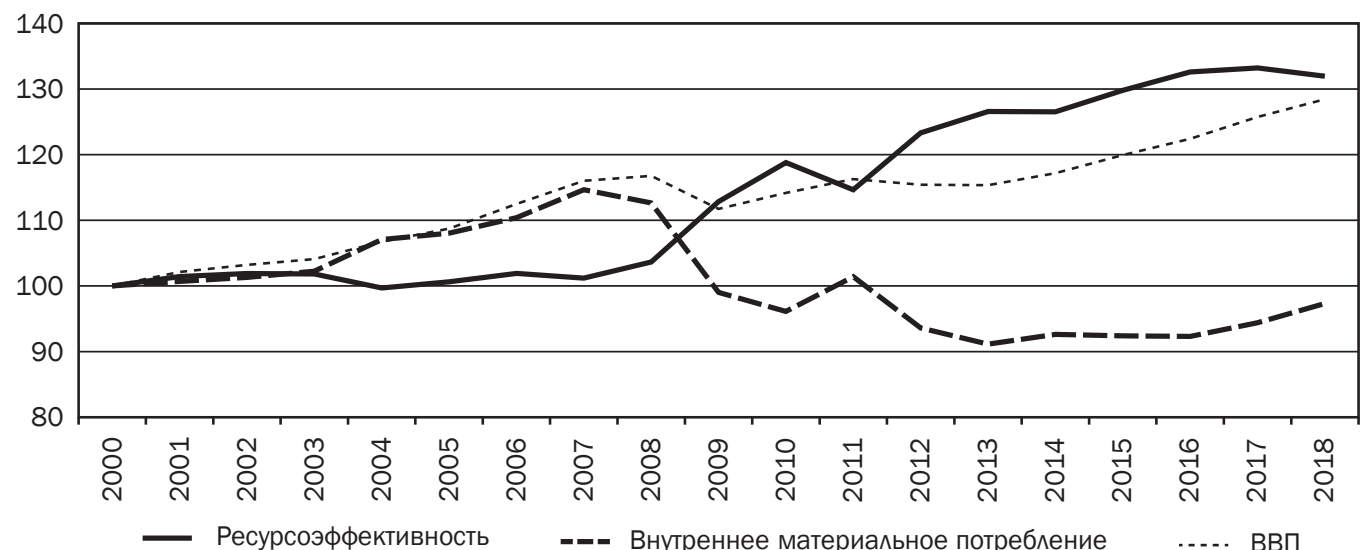

Источник: Resource productivity statistics. Eurostat (online data code: nama_10_gdp, env_ac_mfa; env_ac_rp) / Source: Eurostat (online data code: nama_10_gdp, env_ac_mfa; env_ac_rp).

\footnotetext{
9 Greenhouse gas emissions by source sector / Eurostat (source: EEA). URL: http://appsso.eurostat.ec.europa. eu/nui/show.do?lang=en\&dataset=env_air_gge.

${ }^{10}$ Share of renewable energy in gross final energy consumption / Eurostat (source: EEA). URL: https://ec.europa. eu/eurostat/databrowser/view/t2020_31/default/table?lang=en.
} 
Предоставление одной и той же услуги или продукта с использованием меньшего количества ресурсов является одним из наиболее экономически эффективных способов сокращения выбросов парниковых газов и повышения энергетической безопасности. Аля формирования "зеленой" экономики особое значение имеет "эффект Аекаплинга" (decoupling) как снижение "природоемкости материального производства" (затраты природных ресурсов и объемы загрязнений на единицу выпуска). Аекаплинг рассматривается как "стратегическая основа Авижения к экологически устойчивой экономике, позволяющей рассогласовывать темпы роста благосостояния ^юдей, с одной стороны, и потребления ресурсов и экологического воздействия, с Аругой" [Бобылев С. Н., Захаров В. М., 2012]. “Эффект Аекаплинга" измеряется при помощи различных показатемей природоемкости (материалоемкость, водоемкость, энергоемкость, углеродоемкость и т. А.). ОАним из его показателей выступает ресурсная производительность в экономике как отношение национального продукта (ВВП) к внутреннему материальному потреблению (Аалее также - ВМП). Рост этого показателя, в частности, наблюдался в странах Европейского союза в период с 2000 по 2018 г. (рост на 32 \% Аля ЕС-27) (см. рис. 1).

Рис. 2 иммюстрирует, в какой степени был достигнут “эффект Аекаплинга" в различных странах Европейского союза за периол с 2000 по 2018 г.

Рисунок 2

\section{Изменения внутреннего материального потребления и ВВП по странам в 2000-2018 гг. / \\ Changes of DMC and GDP by country in 2000-2018}

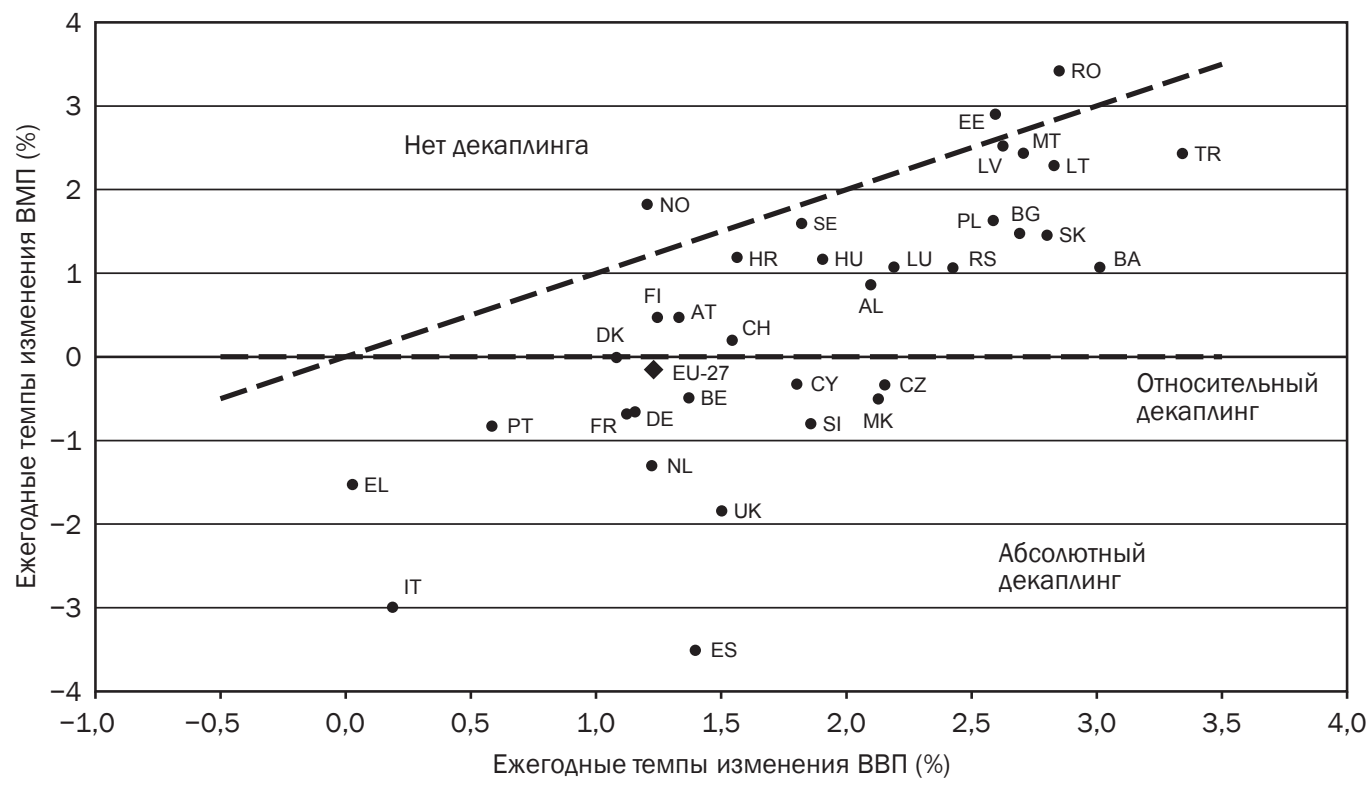

Источник: Eurostat (online data codes: env_ac_mfa, nama_10_gdp) / Source: Eurostat (online data codes: env_ac_mfa, nama_10_gdp)

Аиагональная миния представляет одинаковые темпы изменения как ВВП, так и внутреннего материального потребления. Страны, которые оказались выше этой Аиагональной линии, имели более высокий рост внутреннего материального потребления, чем рост ВВП и, значит, не имели Аекаплинга. Под Аиагональной минией находятся все страны, ВВП которых рос быстрее, чем их ВМП, и, таким образом, они достигли по крайней мере относительного декаплинга. Абсолютный декаплинг означает снижение внутреннего материального потребления при росте ВВП, что было Аостигнуто многими европейскими странами за отчетный периоА, включая экономику ЕС-27 в целом. 
Производство в секторе экологических товаров и услуг увеличилось в 2017 г. на $40 \%$ по сравнению с 2009 г., а занятость в данном секторе возросла на 12 \%. По Аанным Евростата, в 2019 г. общая производительность труда в Европейском союзе возросла на 34,6 \% по сравнению с уровнем 1996 г. ОАнако в результате вычисления темпов прироста показателя и построения графика мы видим, что темпы прироста производительности труда за анализируемый период снизились (см. рис. 3).

Рисунок 3

Темп прироста производительности труда в ЕС-27, в \% к предыдущему году / Labor productivity growth rate in the EU-27, \% to the previous year

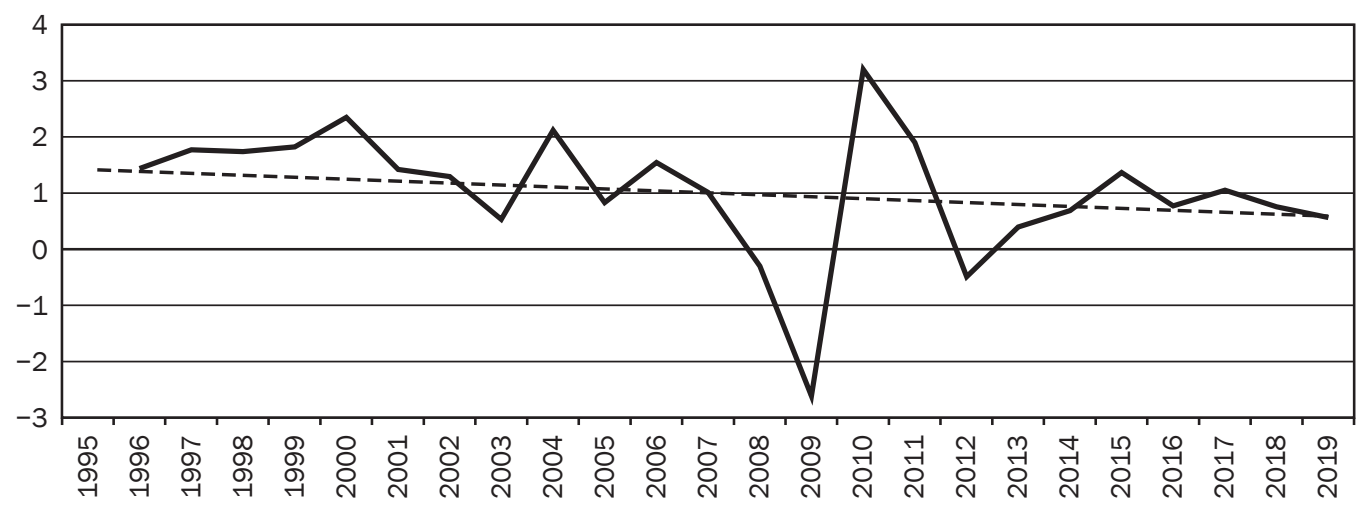

Источник: расчеты авторов на основе официальных данных OECD.stat / Source: authors' calculations based on the official data of the OECD.stat.

Таким образом, в течение наблюдаемого периода 2001-2017 гг. в странах Европейского союза произошло сокращение выбросов парниковых газов, возросли национальные расходы на охрану окружающей среды, увеличилась доля возобновляемых источников энергии в валовом конечном потреблении энергии и повысилась ресурсоэффективность производства.

\section{МОАЕАИРОВАНИЕ ФАКТОРОВ ПРОИЗВОАИТЕАЬНОСТИ ТРУАА В ОБРАБАТЫВАЮЩЕЙ ПРОМЫШАЕННОСТИ РЯАА СТРАН ЕВРОПЕЙСКОГО СОЮЗА}

В настоящем исследовании мы нацелены на эмпирическую проверку гипотезы М. Портера, согласно которой хорошо продуманная экологическая политика может фактически повысить производительность труда в отАельных отраслях и в экономике страны в целом, принося прямые экономические выгоды наряду с экологическими выгодами. Многие страны не спешат внедрять "зеленые" технологии именно из-за представлений об экологических нормах как факторе, негативно сказывающемся на конкурентоспособности предприятий и отраслей.

В связи с тем, что в качестве измерителя эффективности Аля сектора обрабатывающей промышленности в странах Европейского союза в экономике нами был выбран показатель производительности труАа, в соответствующую модель необхоАимо включить ключевые факторы производительности труда. Согласно распространенным теоретическим представлениям определяющими факторами производительности являются: 1) физический капитал, который представляет собой запас оборудования и конструкций, используемых Аля производства товаров и услуг; 2) трудовые ресурсы; 3) человеческий капитал, который состоит из знаний и навыков, приобретаемых через образование, обучение и опыт; 4) природные ресурсы; 5) технологические знания [Naidoo R., 2004; Щетинина ^. В., Рудакова С. Г., 2013]. 
В ходе построения модели мы ставим задачу сопоставить значимость перечисленных и проанализированных факторов "зеленой" экономики. В соответствии с этим мы сформулировали слеАующий набор гипотез.

1. Увеличение предприятиями обрабатывающей промышленности инвестиций, направленных на охрану окружающей среды, способствует росту производительности труда.

2. Рост уровня образования способствует росту производительности труда.

3. Рост участия взрослых в профессиональном обучении повышает производительность труаа.

4. Инвестиции способствуют росту производительности труда.

5. Увеличение затрат на трудовые ресурсы снижает уровень производительности труда.

6. При повышении привлекательности сектора по сравнению с Аругими секторами экономики повышается производительность труда на предприятиях рассматриваемого сектора.

7. При неблагоприятной ситуации на рынке труда производительность труда снижается.

Аля проверки гипотез был проведен корреляционно-регрессионный анализ при помощи прикладного программного пакета Аля построения эконометрических моделей GRETL 1.9.92.

За зависимую переменную у принят показатель производительности труда по добавленной стоимости (валовая Аобавленная стоимость на одного занятого, тыс. евро) Аля сектора обрабатывающей промышленности. В качестве объясняющих переменных использованы показатели: $\mathrm{x}_{1}$ - инвестиции в оборудование и установки Аля борьбы с загрязнением в секторе (евро на одного занятого) и $\mathrm{x}_{2}-$ инвестиции в оборудование и установки, связанные с более чистыми технологиями (интегрированные технологии) в секторе (евро на одного занятого). Аля улучшения спецификации модели были также рассмотрены следующие факторы: $x_{3}$ - инвестиции в секторе обрабатывающей промышленности (тысяч евро на одного занятого); $x_{4}$ - доля затрат на персонал в производстве в секторе (процентов); $x_{5}$ - средние затраты на персонал в секторе (тысяч евро на одного занятого); $x_{6}$ - общие государственные расходы на образование (в процентах к ВВП), Аля всех уровней образования; $x_{7}$ - отношение средней заработной платы в секторе к средней заработной плате в стране; $x_{8}$ - темп прироста занятых в секторе; $x_{9}-$ уровень безработицы (процентов); х 10 -уровень инвестиций в секторе, инвестиции / Аобавленная стоимость по факторам затрат (процентов); $\mathrm{x}_{11}$ - участие взрослых в обучении (процентов) - показатель, измеряющий Аолю ^юдей в возрасте от 25 до 64 лет, которые указали, что они получили формальное или неформальное обучение в течение четырех недель, преАшествующих опросу. Как виАно, часть объясняющих переменных взята в текущих ценах. ОАнако все переменные в модели приведены к удельному виду (как на промежуточном этапе, так и в итоговой модели), что частично снижает возможное воздействие инфляционных трендов на результаты моделирования. Кроме того, у большей части объясняющих переменных фактор инфляции элиминирован (у переменных $\mathrm{x}_{4}, \mathrm{x}_{6}, \mathrm{x}_{7}, \mathrm{x}_{8}, \mathrm{x}_{9}, \mathrm{x}_{10}, \mathrm{x}_{11}$ ), что повышает качество моделирования.

На основе выбранных показателей мы построили модель множественной регрессии с фиксированными эффектами по панельным Аанным с 2001 по 2017 г. Аля семи европейских стран. Выбор этих стран был обусловлен наличием наиболее полных данных Аля анализа. Следует отметить, что эти страны занимают различные позиции в рейтинге Глобального индекса "зеленой" экономики (GGEI) по состоянию на 2018 г. ${ }^{11}$ как в глобальном аспекте, так и в рамках Европейского союза, что позволило обеспечить неоднородность выборки данных модели относительно ситуации по Европейскому союзу в целом (см. табл. 1).

\footnotetext{
${ }^{11}$ The Global Green Economy Index: Dual citizen. URL: https://dualcitizeninc.com/global-green-economy-index/.
} 
Таблица 1

\section{Рейтинг стран из выборки модели по Глобальному индексу “зеленой" экономики / Ranking of model sample countries in Global Green Economy Index}

\begin{tabular}{|c|c|c|}
\hline Страна из выборки модели & Место страны в мировом рейтинге & Величина индекса \\
\hline Швеция & 1 & 0,7608 \\
\hline Германия & 6 & 0,6890 \\
\hline Нилерланды & 17 & 0,5937 \\
\hline Италия & 25 & 0,5606 \\
\hline Испания & 34 & 0,5411 \\
\hline Чехия & 69 & 0,4773 \\
\hline Кипр & 86 & 0,4511 \\
\hline
\end{tabular}

Источник: The Global Green Economy Index: Dual citizen (https://dualcitizeninc.com/global-green-economy-index/) / Source: The Global Green Economy Index: Dual citizen (https://dualcitizeninc.com/global-green-economy-index/).

Так, Швеция (первое место из 130 стран мира), Германия (шестое место), Нидерланды (17-е место) занимают высокие позиции в индексе, Италия (25-е место) и Испания (34-е место) - средние позиции, а Чехия (69-е место) и Кипр (86-е место) - низкие позиции среди стран Европейского союза. Таким образом, выбор данных стран не является произвольным или случайным, но продиктован ограничениями имеющихся статистических Аанных и, кроме того, Аает неоднородную выборку, что приводит к более объективным результатам моделирования.

В ходе промежуточного моделирования были протестированы различные варианты моделей, в том числе модели панельных данных, включающие каговые переменные таких показателей, как "инвестиции в секторе обрабатывающей промышленности" и «инвестиции в оборудование и установки Аля борьбы с загрязнением в секторе обрабатывающей промышленности", в силу того что они могут приводить к эффекту с некоторым запозданием. При использовании лагового значения "1" зависимость межАу показателями осталась неизменной. Все объясняющие переменные сохранили свою значимость на уровнях от $10 \%$ и выше. Тестирование подтвердило нормальное распределение ошибок и отсутствие гетероскеАастичности в модели. При использовании лагового значения "2" зависимость и значимость всех показателей, кроме отношения средней заработной платы в секторе обрабатывающей промышленности к средней заработной плате в стране, также сохранилась.

В результате моделирования мы получили следующее наиболее статистически значимое уравнение регрессии с лаговым значением "0":

$$
\ln y=4,56+0,023 * \ln x_{1}+0,190 * \ln x_{3}-0,665 * \ln x_{4}+0,402 \ln x_{7}+0,265 * \ln x_{11} .
$$

Коэффициент Аетерминации модели $\left(R^{2}\right)$ равен 0,9718. Это означает, что 97,18 \% вариации объясняемой переменной (производительности труда) обусловлено влиянием факторов, включенных в модель. Проверка значимости параметров модели показала, что параметры инвестиций в оборудование и установки Аля борьбы с загрязнением, Аоли затрат на персонал в производстве в секторе обрабатывающей промышленности, уровня инвестиций и участия взрослых в обучении значимы на уровне 1 \%, параметр отношения средней заработной платы в секторе обрабатывающей промышленности к средней заработной плате в стране значим на уровне 5 \%. Остальные факторы оказались незначимыми. Выводы о значимости параметров были получены на основе р-значений. F-критерий также подтвердил значимость уравнения регрессии в целом.

Отметим, что в результате корреляционного анализа не обнаружена статистически значимая высокая корреляционная связь между объясняющими переменными, включенными 
в итоговую модель панельных Аанных. Аальнейшая Аиагностика различных вариантов модели обнаружила, что наилучшим способом оценки является модель с фиксированными эффектами, которая позволяет учитывать неизмеримые индивидуальные различия объектов. Тест на нормальное распределение показал, что остатки распределены по нормальному закону. Тест Вальда на гетероскеАастичность подтвердил отсутствие гетероскеАастичности остатков.

Таким образом, согласно регрессионному анализу производительность труда в секторе обрабатывающей промышленности находится в прямой зависимости от инвестиций в оборудование и установки Аля борьбы с загрязнением окружающей среды. При повышении инвестиций в оборудование и установки Аля борьбы с загрязнением на 1 \% производительность труда вырастет на 0,023 \%. Таким образом, гипотеза о том, что инвестиции в технологии, снижающие вредное воздействие на окружающую среду, имеют положительное влияние на производительность труда, подтверждается.

Кроме того, исходя из уравнения, получаем, что чем больше инвестиций в расчете на одного занятого, тем выше производительность труда. При росте инвестиций на одного занятого на 1 \% производительность вырастает на 0,19\%. Аалее подтвердилась обратная зависимость производительности труда от показателя "Аоля затрат на персонал в производстве в секторе»). При повышении доли затрат на персонал в производственных затратах на 1 \% производительность труда уменьшается на 0,665 \%.

Также при повышении показателя "отношение средней заработной платы в секторе к средней заработной плате в стране" на 1 \% производительность труда вырастает на 0,402 \%. Это, вероятно, связано с тем, что заработная плата коррелирует с предлагаемым сотрудниками человеческим капиталом. Чем выше средняя зарплата в секторе относительно средней заработной платы в стране, тем более квалифицированные сотрудники требуются в сектор, и, следовательно, выше производительность труда.

Наконец, значимым фактором повышения производительности труда является участие взрослых в обучении. При увеличении доли участия взрослых в обучении на $1 \%$ произвоАительность труда вырастет на 0,265 \%.

\section{ОБСУЖАЕНИЕ РЕЗУАЬТАТОВ}

Результаты эмпирического анализа показали, что в секторе обрабатывающей промышленности инвестиции в оборудование и установки Аля борьбы с загрязнением положительно влияют на производительность труда. Так, можно рассматривать вопрос внедрения "зеленых" технологий в производство как актуальный и целесообразный с точки зрения экономической эффективности.

Как уже было упомянуто авторами, в научной митературе существует Аискуссия об экономической целесообразности технологий "зеленой" экономики. Можно отметить, что ряд современных исследований опровергают сложившийся ранее стереотип о том, что "зеленые" технологии являются слишком Аорогостоящими. Особенность современных "зеленых" технологий заключается в их инновационности, нацеленности на ресурсосбережение и повышение отАачи от используемых ресурсов, прежде всего в среднесрочной и Аолгосрочной перспективе. Например, согласно ежегодному докладу по экономике электроэнергетики Международного агентства по возобновляемым источникам энергии (IRENA) “Стоимость производства электроэнергии из возобновляемых источников в 2019 году" издержки производства энергии новых солнечных и ветровых электростанций в 2019 г. были ниже, чем у энергопреАприятий, работающих на самом Аешевом ископаемом топливе, а именно у существующих угольных электростанций ${ }^{12}$.

${ }^{12}$ Renewable Power Generation Costs in 2019 / International Renewable Energy Agency, 2020. URL: https:// irena.org/publications/2020/Jun/Renewable-Power-Costs-in-2019. 
В настоящий момент в научной среде преобладает мнение, что успешное формирование "зеленой" экономики в той или иной стране невозможно без интеграции усилий всех ключевых субъектов национальной экономики (государства, бизнеса, населения). При этом важнейшим фактором успеха становятся механизмы и инструменты финансирования "зеленой" экономики, реализуемые в основном в банковской системе, в секторе страхования, через государственные институты развития [Яковлев И. А. и Ар., 2017].

Также очень важна роль государственной поддержки в стимулировании экономических преобразований. И. А. Яковлев, А. С. Кабир и Аругие выделили пять ключевых направлений возАействия правительств Аля благоприятного развития "зеленой" экономики.

"К ним относят:

- государственные инвестиции и расходы (оптимизация затрат в областях, стимулирующих "зеленую" экономику);

- использование экологических налогов и других рыночных инструментов, минимизирующих внешнее воздействие на окружающую среду и компенсирующих слабость рынка;

- реформирование экологически вредных бюджетных субсидий (ограничение госуАарственной подАержки отраслей, истощающих природный капитал);

- улучшение законодательного регулирования;

- развитие межАународного сотрудничества в сфере экологии и ресурсопользования" [Яковлев И. А. и Ар., 2017].

Наше исследование актуально и Аля России, поскольку важно сохранить природный капитал страны, повысить благосостояние населения при оАновременном повышении эффективности производства различных секторов экономики, включая обрабатывающую промышленность. Россия постепенно предпринимает шаги по вк^ючению в современную глобальную экосистему в области устойчивого финансирования и ответственной инвестиционной практики. ОАнако в настоящий момент в нашей стране "отсутствует эффективная модель финансирования "зеленого" роста" [Бокарев А. А., и Ар., 2017]. Проверка гипотезы о том, что переход к “зеленой" экономике положительно влияет на производительность труда, Аает возможность расширить круг источников инвестиций, сделать это направление привлекательным Аля частных инвесторов и стимулировать меры государственной подАержки.

Помимо инвестиций в "зеленые" технологии исследование подтвердило важность развития человеческого капитала, что в свою очередь является одним из показателей социального аспекта "зеленой" экономики. ВеАь "зеленая" экономика - это концепция, принципы которой заложены в экономической, социальной и экологической сферах. Она признает, что экосистемы, экономика и благосостояние людей неразрывно связаны.

Так, человеческий и природный капитал имеют тесную взаимосвязь. Е. А. Марыганова и Н. А. Амитриевская отмечают, что человеческий капитал непосредственно влияет на природный капитал и наоборот. Во-первых, по мере развития знаний и навыков ^юди могут разрабатывать и использовать новые технологии, решающие экологические проблемы, более эффективно использовать имеющиеся ресурсы или искать дополнительные. Во-вторых, рост национального дохода как результат реализации возможностей человеческого капитала предоставляет ресурсы Аля решения широкого круга экологических проблем. Кроме того, рост населения неизбежно влечет за собой рост антропогенной нагрузки. С Аругой стороны, природный капитал - это необходимое условие в экономике Аля воспроизводства человеческого капитала. Экосистемы и природные ресурсы являются основой экономической активности и средой жизнедеятельности населения [Марыганова Е. А., Амитриевская Н. А., 2013].

Затраты на обучение и переквалификацию сотрудников помогут в переходе на «зеленые" рабочие места, то есть "рабочие места в сфере сельского хозяйства, обрабатывающей промышленности, научных исследований и разработок, аАминистративных видах 
Аеятельности, которые вносят существенный вклаА в сохранение или восстановление качества окружающей среды»13.

Таким образом, такие меры на уровне государства и частных компаний, как инвестиции в обучение взрослого населения, будут способствовать не только росту производительности труда, но и переходу к “зеленой" экономике.

\section{ЗАКАЮЧЕНИЕ}

Термин "зеленая" экономика был впервые введен в научный оборот в 1989 г., однако Ао сих пор нет единого определения Аанной концепции. В результате анализа авторами существующих опреАелений можно сАелать вывоА о том, что поА “зеленой" экономикой, как правило, понимается Аинамический процесс трансформации хозяйственного уклаАа экономики в направлении низкоуглеродного производства, ресурсосбережения, обеспечения устойчивого экономического роста и повышения благосостояния населения посредством создания и применения технологий, которые одновременно снижают риски Аля окружающей среды и созАают новые рабочие места в Аолгосрочном периоде.

Анализ основных методов измерения "зеленой" экономики в мировой практике позволяет говорить о целесообразности использования в первую очередь показателей "зеленого" роста, преАложенных ОЭСР, индикаторов, преАложенных программой ООН по окружающей среле, и показателей счета сектора экологических товаров и услуг, разработанных Евростатом. Анализ упомянутых индикаторов показал, что в странах Европейского союза достаточно результативно реализуются меры по "озеленению" экономики.

В количественной части исследования была произведена эконометрическая оценка эмпирической модели на основе панельных данных с фиксированными эффектами, им^юстрирующая взаимосвязь производительности труда с рядом факторов Аля отрасли обрабатывающей промышленности семи европейских стран за период 2001-2017 гг. Результаты моделирования показывают, что значимое влияние на производительность труда в обрабатывающей промышленности европейских стран оказывают инвестиции в оборудование и установки Аля борьбы с загрязнением, инвестиции в целом, участие взрослых в непрерывном обучении и уровень заработной платы. Затраты на трудовые ресурсы имеют отрицательную взаимосвязь с производительностью труда.

Полученные результаты могут быть использованы при разработке преАложений по привлечению государственных и частных инвестиций в развитие "зеленой" экономики как в Европейском союзе, так и в Аругих развитых и развивающихся странах, в частности в России.

\footnotetext{
${ }^{13}$ Green Jobs: Towards decent work in a sustainable, low-carbon world / UNEP, ILO, OIE, ITUC, 2008.
} 


\section{Список источников}

Бобылев С. Н., Захаров В. М. “Зеленая" экономика и модернизация. Эколого-экономические основы устойчивого развития // На пути к устойчивому развитию: бюмлетень Ин-та устойчивого развития Обществ. палаты РФ. 2012. № 60, 90 с.

Бокарев А. А., Яковлев И. А., Кабир ^. С. «Зеленые» инвестиции в России: поиск приоритетных направлений // Научно-исследовательский финансовый институт. Финансовый журнал. 2017. № 6. С. 40-49.

Бочко В. С. Зеленая экономика: вторая вечная проблема человечества // Вестник УрФУ. Серия: Экономика и управление. 2014. № 3. С. 113-119.

Марыганова Е. А., Амитриевская Н. А. Человеческий капитал как фактор устойчивого развития // Статистика и экономика. 2013. № 6. С. 73-78.

Порфирьев Б. Н. Природа и экономика: риски взаимодействия (эколого-экономические очерки) / ПоА реА. В. В. Ивантера. М.: Анкил, 2011. 352 с.

Щетинина ^. В., Рудакова С. Г. Факторный анализ производительности труда // Экономика: реалии времени. 2013. № 5 (10). С. 102-108.

Яковлев И. А., Кабир ^. С., Никулина С. И. и Ар. Финансирование "зеленого" экономического роста: концепции, проблемы, поАходы // Научно-исслеАовательский финансовый институт. Финансовый журнал. 2017. № 3. C. 9-21.

Albrizio S., Kozluk T., Zipperer V. Environmental policies and productivity growth: Evidence across industries and firms // Journal of Environmental Economics and Management. 2017. Vol. 81 (C). P. 209-226. URL: https:// doi.org/10.1016/j.jeem.2016.06.002.

Amara N., Traoré N., Landry R. et al. Technical Efficiency and Farmers' Attitudes toward Technological Innovation: The Case of the Patato Farmers in Quebec // Canadian Journal of Agricultural Economics. 1999. Vol. 47. P. $31-43$. URL: https://doi.org/10.1111/j.1744-7976.1999.tb00214.x.

Borel-Saladin J. M., Turok I. N. The Green Economy: Incremental Change or Transformation? // Environmental Policy and Governance. 2013. Vol. 23. Iss. 4. P. 209-220. URL: https://doi.org/10.1002/eet.1614.

Christainsen G. B., Haveman R. H. Public Regulations and the Slowdown in Productivity Growth // The American Economic Review. 1981. Vol. 71. Iss. 2. P. 320-325.

Denison E. F. Pollution Abatement Programs: Estimates of Their Effect Upon Output Per Unit of Input, 1975-78 // Survey of Current Business. 1979. Vol. 59. Iss. 8. Part 1. P. 58-59.

Dufour C., Lanoie P. Patry M. Regulation and productivity // Journal of Productivity Analysis. 1998. Vol. 9. P. 233-247. URL: https://doi.org/10.1023/A:1018387021327.

Georgeson L., Maslin M., Poessinouw M. The global green economy: a review of concepts, definitions, measurement methodologies and their interactions // Geo: Geography and Environment Journal. 2017. Vol. 4. Iss. 1. P. 1-23. URL: https://doi.org/10.1002/geo2.36.

Gollop F. M., Roberts M. J. Environmental Regulations and Productivity Growth: The Case of Fossil-Fueled Electric Power Generation // Journal of Political Economy. 1983. Vol. 91. P. 654-674.

Hopkins C. The Green Economy: A Primer / Green Economy Coalition, 2017. URL: https://www.greeneconomycoalition.org/news-analysis/the-green-economy-a-primer.

Issoufou S., Ouattara N. Does Green Investment Raise Productivity? 2011. URL: https://www.uneca.org/sites/ default/files/uploaded-documents/AEC/2011/issoufou_and_ouattara-does_green_investment_raise_productivity_ paper_0.pdf.

Lin R., Sheu C. Why Do Firms Adopt/Implement Green Practices? An Institutional Theory Perspective // Procedia - Social and Behavioral Sciences. 2012. Vol. 57. P. 533-540. URL: https://doi.org/10.1016/j.sbspro. 2012.09.1221.

Naidoo R. Economic Growth and Liquidation of Natural Capital: The Case of Forest Clearance // Land Economics. University of Wisconsin Press. 2004. Vol. 80. Iss. 2. P. 194-208. URL: https://doi.org/10.2307/3654738.

Pearce D., Markandya A., Barbier E. R. Blueprint for a Green Economy. London: Earthscan Publications Ltd, 1989. 192 p.

Porter M. America's Green Strategy // Scientific American. 1991. Vol. 264. Iss. 4.

Porter M., van der Linde C. Toward a New Conception of the Environment-Competitiveness Relationship // Journal of Economic Perspective. 1995. Vol. 9. Iss. 4. P. 97-118. URL: https://doi.org/10.1257/jep.9.4.97.

Rehman M. A. A., Shrivastava R. L. Green manufacturing (GM): past, present and future (a state of art review) // World Review of Science. Technology and Sustainable Development. 2013. Vol. 10. No. 1/2/3. P. 17-55. URL: https://doi.org/10.1504/WRSTSD.2013.050784.

Поступила в реАакцию 6 июля 2020 г. Принята к публикации 19 августа 2020 г. 


\section{References}

Albrizio S., Kozluk T., Zipperer V. (2017). Environmental policies and productivity growth: Evidence across industries and firms. Journal of Environmental Economics and Management, vol. 81 (C), pp. 209-226. Available at: https://doi.org/10.1016/j.jeem.2016.06.002.

Amara N., Traoré N., Landry R. et al. (1999). Technical Efficiency and Farmers' Attitudes toward Technological Innovation: The Case of the Patato Farmers in Quebec. Canadian Journal of Agricultural Economics, vol. 47, pp. 31-43. Available at: https://doi.org/10.1111/j.1744-7976.1999.tb00214.x.

Bobylev S.N., Zakharov V.M. (2012). Economic and Environmental Outlines of Sustainable Development. Na puti k ustoychivomu razvitiyu: byulleten' In-ta ustoychivogo razvitiya Obshchestv. palaty RF - Towards a Sustainable Russia: Bulletin of the Institute of Sustainable Development of the RF Civic Chamber, no. 60. 90 p. (In Russ.).

Bochko V.S. (2014). Green Economy: the Second Eternal Problem of Mankind. Vestnik UrFU. Seriya: Ekonomika i upravleniye - Bulletin of UrFU. Series: Economics and Management, no. 3, pp. 113-119 (In Russ.).

Bokarev A.A., Yakovlev I.A., Kabir L.S. (2017). Green Investments in Russia: Searching for Priority Directions. Finansovyj žhurnal - Financial Journal, no. 6, pp. 40-49 (In Russ.).

Borel-Saladin J.M., Turok I.N. (2013). The Green Economy: Incremental Change or Transformation? Environmental Policy and Governance, vol. 23, no. 4, pp. 209-220. Available at: https://doi.org/10.1002/eet.1614.

Christainsen G.B., Haveman R.H. (1981). Public Regulations and the Slowdown in Productivity Growth. The American Economic Review, vol. 71, no. 2, pp. 320-325.

Denison E.F. (1979). Pollution Abatement Programs: Estimates of Their Effect Upon Output Per Unit of Input, 1975-78. Survey of Current Business, vol. 59, no. 8, part 1, pp. 58-59.

Dufour C., Lanoie P., Patry M. (1998). Regulation and productivity. Journal of Productivity Analysis, vol. 9, pp. 233-247. Available at: https://doi.org/10.1023/A:1018387021327.

Georgeson L., Maslin M., Poessinouw M. (2017). The global green economy: a review of concepts, definitions, measurement methodologies and their interactions. Geo: Geography and Environment Journal, vol. 4, no. 1, pp. 1-23. Available at: https://doi.org/10.1002/geo2.36.

Gollop F.M., Roberts M.J. (1983). Environmental Regulations and Productivity Growth: The Case of Fossil-Fueled Electric Power Generation. Journal of Political Economy, vol. 91, pp. 654-674.

Hopkins C. (2017). The Green Economy: A Primer. Green Economy Coalition. Available at: https://www. greeneconomycoalition.org/news-analysis/the-green-economy-a-primer.

Issoufou S., Ouattara N. (2011). Does Green Investment Raise Productivity? Available at: https://www.uneca. org/sites/default/files/uploaded-documents/AEC/2011/issoufou_and_ouattara-does_green_investment_raise_ productivity_paper_0.pdf.

Lin R., Sheu C. (2012). Why Do Firms Adopt/Implement Green Practices? An Institutional Theory Perspective. Procedia - Social and Behavioral Sciences, vol. 57, pp. 533-540. Available at: https://doi.org/10.1016/ j.sbspro.2012.09.1221.

Maryganova E.A., Dmitrievskaya N.A. (2013). Human Capital as a Factor in Sustainable Development. Statistika i ekonomika - Statistics and Economics, no. 6, pp. 73-78 (In Russ.).

Naidoo R. (2004). Economic Growth and Liquidation of Natural Capital: The Case of Forest Clearance. Land Economics, University of Wisconsin Press, vol. 80, no. 2, pp. 194-208. Available at: https://doi.org/10.2307/ 3654738.

Pearce D., Markandya A., Barbier E.R. (1989). Blueprint for a Green Economy. London: Earthscan Publications Ltd, $192 \mathrm{p}$.

Porfiryev B.N. (2011). Nature and Economics: the Risks of Interaction (environmental and economic essays). Ed. V.V. Ivanter. Moscow: Ankil Publ. 352 p. (In Russ.).

Porter M. (1991). America's Green Strategy. Scientific American, vol. 264, no. 4.

Porter M., van der Linde C. (1995). Toward a New Conception of the Environment Competitiveness Relationshi. Journal of Economic Perspective, vol. 9, no. 4, pp. 97-118. Available at: https://doi.org/10.1257/jep.9.4.97.

Rehman M.A.A., Shrivastava R.L. (2013). Green manufacturing (GM): past, present and future (a state of art review). World Review of Science, Technology and Sustainable Development, vol. 10, no. 1/2/3, pp. 17-55. Available at: https://doi.org/10.1504/WRSTSD.2013.050784.

Shchetinina, L.V., Rudakova, S.G. (2013). Factor Analysis of Labor Productivity. Ekonomika: realii vremeni Economics: Realities of Time, no. 5 (10), pp. 102-108 (In Russ.).

Yakovlev I.A., Kabir L.S., Nikulina S.I. et al. (2017). Financing Green Economic Growth: Conceptions, Problems, Approaches. Finansovyj žhurnal - Financial Journal, no. 3, pp. 9-21 (In Russ.).

Received 06.07.2020

Accepted for publication 19.08.2020 


\title{
"Новая индустриализация" в России как фактор перехода к "зеленой" экономике
}

\author{
Ирина Павловна Аовбий, А. э. Н., профессор кафедры «Экономическая безо- \\ пасность" Южно-Уральского государственного университета, г. Челябинск \\ E-mail: betelgeyse@mail.ru \\ Алексей Николаевич Аеттеренко, аспирант частного образовательного \\ учреждения высшего образования "Международный Институт Аизайна \\ и Сервиса", г. Челябинск \\ E-mail: adegterenko@yandex.ru \\ Влада Валерьевна Кобылякова, аспирант кафедры “Экономическая безо- \\ пасность" Южно-Уральского государственного университета, г. Челябинск \\ E-mail: krutova.94@inbox.ru
}

\begin{abstract}
Аннотация
Настоящее исследование раскрывает условия и факторы "новой индустриализации" в контексте возрастающей необходимости перехода России к новой "зеленой" модели экономического роста. Можно предположить, что следствием мирового структурного кризиса, вызванного COVID-19, станет усиление требований экологических стандартов. Последние могут оказаться мощным инструментом конкурентной борьбы компаний и государств за рынки ресурсов и рынки сбыта. В России "новая индустриализация" Аолжна стать основой Аля "озеленения" экономики, поскольку Аля этого имеются определенные предпосылки. В статье исследованы различные факторы, условия, тренды, требования и признаки, которым Аолжна соответствовать "новая индустриализация", чтобы обеспечить устойчивое развитие и конкурентоспособность на мировых рынках. В теоретическом аспекте авторы сделали аргументированный вывод о Аиалектическом еАинстве процессов "новой индустриализации" и "Озеленения" экономики. Если будут выполнены определенные условия, в частности, приоритетное развитие реального сектора экономики на новейшей технологической основе, формирование новой технократической элиты с компетенциями интемектуального обеспечения политики "новой индустриализации", наращивание интемектуального потенциала научных и инженерно-технических кадров, реализующих новые научные направления и разработки конкурентных технологий, то можно будет говорить о том, что "новая индустриализация" является фактором перехода к расширенному “зеленому" воспроизводству национальной экономики.
\end{abstract}

Ключевые слова: "новая индустриализация", наилучшие Аоступные технологии, устойчивое развитие, "зеленая" экономика, государственная промышленная политика, COVID-19, мировой структурный кризис

JEL: D02, 014, 044

Аия цитирования: Аовбий И. П., Аегтеренко А. Н., Кобылякова В. В. "Новая индустриализация" в России как фактор перехода к "зеленой" экономике // Финансовый журнал. 2020. T. 12 . № 4. C. 85-100. DOI: 10.31107/2075-1990-2020-4-85-100. 
DOI: 10.31107/2075-1990-2020-4-85-100

\title{
"New Industrialization" in Russia as a Factor in the Transition to a Green Economy
}

Irina P. Dovbiy ${ }^{1}$

E-mail: betelgeyse@mail.ru

Alexey $\mathbf{N}$. Degterenko ${ }^{2}$

E-mail: adegterenko@yandex.ru

Vlada V. Kobilyakova ${ }^{1}$

E-mail: krutova.94@inbox.ru

${ }^{1}$ South Ural State University, Chelyabinsk 454080, Russian Federation

${ }^{2}$ International Institute of Design and Service, Chelyabinsk 454014, Russian Federation

\begin{abstract}
The present study reveals the conditions and factors of "new industrialization" in the context of the growing need for Russia to transition to a new, green model of economic growth. It can be assumed that the consequences of the global structural crisis caused by COVID-19 will raise the requirements of environmental standards. The latter can become a powerful tool in the competition between companies and states for resource and sales markets. In Russia, "new industrialization" should become the basis for the greening of the economy, since there are certain prerequisites for this. The authors have investigated various factors, conditions, trends, requirements and features that the new industrialization must meet in order to ensure sustainable development and competitiveness in global markets. In the theoretical aspect, the authors have made a reasoned conclusion about the dialectical unity of the processes of "new industrialization" and greening of the economy. If certain conditions are met - in particular, priority development of the real sector of the economy on the latest technological basis, formation of a new technocratic elite with competencies for the intellectual provision of the "new industrialization" policy, and building up of the intellectual potential of scientists, engineers and technicians pursuing new scientific directions and development of competitive technologies - it will be possible to say that "new industrialization" is a factor of transition to expanded green reproduction of the national economy.
\end{abstract}

Keywords: "new industrialization", best available techniques, sustainable development, green economy, COVID-19, global structural crisis

JEL: D02, 014, 044

For citation: Dovbiy I.P., Degterenko A.N., Kobilyakova V.V. "New Industrialization" in Russia as a Factor in the Transition to a Green Economy. Financial Journal, 2020, vol. 12, no. 4, pp. 85-100 (In Russ.). DOI: 10.31107/2075-1990-2020-4-85-100.

\section{BBEAEHИE}

На закате неолиберальной эпохи возрастают тренды "зеленого" развития российской экономики. Это порождает горячие Аискуссии вокруг различных концепций и моделей ее развития. При этом акценты ставятся на необходимость качественного обновления технологической базы в обрабатывающей промышленности, создающей предпосылки Аля формирования отраслей высшего технологического уклада: технологические инновации воплощаются прежде всего в "метамме». ОАновременно проходит "озеленение" финансовой системы на принципах "зеленого" (ответственного) финансирования: на национальном уровне разрабатываются рекомендации, правила и стандарты.

Аля российской экономики технологическое отставание грозит усилением экологических проблем, потерей производительности и конкурентоспособности. На повестку Аня 
выходит “новая индустриализация" ${ }^{1}$, под которой в России понимается восстановление, Аинамическое наверстывание и опережающее развитие материально-технической базы национальной экономики. По мнению авторов, она Аолжна сочетать в себе черты четвертой промышленной революции с вектором Авижения к "зеленой" экономике.

\section{МИРОВОЙ СТРУКТУРНЫЙ КРИЗИС И ТРЕНАЫ “ЗЕАЕНОГО॥ РАЗВИТИЯ}

Основным признаком современного этапа научно-технического развития яв^яется глобальная трансформация, означающая постепенный переход экономик различных госуАарств к шестому технологическому укладу. Его ключевым признаком становится интенсивное инновационное обновление основного капитала на основе NBIC-технологий ${ }^{2}$ при условии соблюАения принципов устойчивого развития (sustainable development) - концепции по управлению процессами социально-экономического развития человечества в совокупности с охраной окружающей среды и сохранением биосферы, сформулированной ООН. Страны-участницы берут на себя обязательства по осуществлению политики перехода к "зеленой" экономике, реализуя мероприятия по экологизации промышленности и "озеленению" финансовой системы [Кабир ^. С., 2017]. ОАновременно XXI в. открыл новый этап в развитии финансовых рынков - эпоху ответственного финансирования (ESG-finance), основанную на учете трех факторов риска: экологических, социальных и управленческих (ESG - Environmental, Social, Governance). В числе тенденций, которые Аолжны закрепить переход к “зеленой" экономике, слеАует назвать, с оАной стороны, увемичение государственных инвестиций и расходов в "зеленые" проекты, с Аругой - отказ от госуАарственного субсиАирования экологически вреАных произвоАств.

Мировой кризис 2020 г., вызванный пандемией COVID-19, сопровождавшийся беспрецедентными карантинными мерами и массовой остановкой широкого спектра преАприятий, ускорил процесс развития структурного кризиса, на пороге которого стояла глобальная экономика. По мнению ученых, «пандемия COVID-19, разорвав глобальные цепочки созАания стоимости, показала реальный уровень глобализации мировой экономики - Ао этого многим она преАставлялась некоей формальной и мало ощутимой на практике категорией” [Белов В. Б., 2020]. А послеАствия пандемии будут оказывать влияние на национальные экономики многих стран в Алительной перспективе [ПазАникова Н. П. и Ар., 2020]. Фактически за три-четыре месяца произошло такое сжатие реальных и финансовых рынков, которое характерно Аля мировых кризисов и, как правило, происходит в течение трех-четырех лет. ОАнако предпосылок Аля столь же быстрого восстановления экономики нет, пожалуй, ни в одной стране мира, и, скорее всего, продолжится структурный спаА. Кризис сгладил проблему глобального перепроизводства и ярко обозначил переход к новой экономической реальности, в которой:

- редуцирование организации бизнеса сопровожАается изменением воззрений на трудовую Аеятельность и упрощением трудовых отношений; одновременно резко высвобожАается большое количество невостребованной рабочей силы, увеличивая число безработных;

- основой коммуникационного взаимодействия становятся цифровые технологии и виртуализация, охватившие такие области, как аАминистративные и финансовые услуги, Аистанционное образование и пр.;

1 Следует уточнить, что развитые страны Запада, осуществляя процесс возвращения ранее выведенных за рубеж промышленных производств, также называют Аанный процесс “новой индустриализацией". В России Аанное понятие имеет более глубокий смысл, связанный с переходом к новому технологическому укладу.

2 NBIC-технологии (N - нанотехнологии, B - биотехнологии, I - информационные технологии, C-когнитивные технологии) определяют вектор развития технологий в XXI в. 
- изменилось отношение людей к деньгам в силу чрезвычайной закредитованности населения, с одной стороны, и массового обнищания на фоне аАминистративно установленных карантинных мер, с Аругой. Обозначились первые черты перехода от общества потребления к обществу рационального (разумного) потребления;

- "зеленый тренА" В виАе улучшения экологической обстановки в периоА пандемии (снижение мирового объема выбросов $\mathrm{CO}_{2}$ на 5 \%), по мнению политиков, экономистов и экологов, Аолжен быть не просто сохранен, он Аолжен стать частью глобальной стратегии устойчивого развития, направленной на повышение качества жизни ^юАей всех мировых экономик. Меры по восстановлению рынков, принимаемые правительствами развитых стран Аля ускорения перехола к “зеленой" энергетике, могут стать формой контроля наА объемами материального производства.

Перечисленное являет собой Аалеко не полный перечень трендов, которые Аолжны быть приняты во внимание в процессе Авижения человечества к "зеленой" экономике. Россия позиционируется в качестве оАного из веАущих игроков в системе глобальных интересов, что порожАает новые вызовы и угрозы в области социально-экономического развития, системных и управленческих реформ, экономической модернизации. Цели устойчивого развития получили закрепление в национальной политике в виде Авенадцати национальных проектов, выполнение которых определяет вектор Авижения к "зеленой" экономике.

\section{АВИЖЕНИЕ К “ЗЕАЕНОЙ" ЭКОНОМИКЕ И ПРЕАПОСЫАКИ "НОВОЙ ИНАУСТРИААИЗАЦИИ" РОССИИ}

Экономически развитые страны начали Авижение к "зеленой" экономике уже в 1970-х гг. На фоне четвертой арабо-израильской войны страны - члены ОПЕК практически прекратили поставки нефти в Европу и США, вызвав беспрецелентный топливный (энергетический) кризис и рост цен на нефть в четыре раза. В числе прочих проявлений кризиса впервые крайне остро встала проблема энергосбережения: были введены жесткие ограничительные меры на энергопотребление, пользование автотранспортом. Промышленное производство в Европе сократилось почти на 14 \%, акции веАущих американских компаний рухнули на треть. Фактически кризис стал одним из факторов, опреАеливших курс на низкоуглеродную ресурсоэффективную модель экономики.

В мире начался поиск механизмов, обеспечивающих последующим поколениям устойчивое сбалансированное будущее. Эти механизмы впервые были обозначены в принятой Конференцией ООН в 1992 г. "Повестке Аня на XXI век». В 2012 г. на аналогичной конференции странами было принято решение о необходимости инвестирования в "озеленение" порядка 2 \% глобального ВВП Аля перевода глобальной экономики на низкоуглеродный ресурсоэффективный путь “зеленого" развития. В России развитию “зеленой" экономики правительством уделяется недостаточно внимания, а промышленные компании рассматривают ее в качестве препятствия к развитию.

Следует уточнить, что топливный кризис был на руку Советскому Союзу, активно осваивавшему западносибирские месторождения. Аоля "нефтедомларов" существенно превышала остальные статьи бюАжета, значительная часть расходов которого направлялась на вооружение, закупку на Западе товаров народного потребления, зерна и продовольствия. С одной стороны, советская экономика была основательно переориентирована на рельсы ресурсного развития, с Аругой - значительные средства направлялись на разработку военных, космических, ялерных и Аругих технологий.

Россия конца 1980-х - начала 1990-х представляла собой ведущую технологическую Аержаву с инновационным технологическим заделом на Аесятки лет вперед. ОАнако за почти тридцатилетний период реформ страна, по мнению Е. Б. Аенчук, превратилась "в потребителя зарубежных Аалеко не всегАа передовых технологий", что поставило 
"ПоА угрозу технологический суверенитет страны" [^енчук Е. Б., 2017, с. 22]. Причиной Аеградации российской экономики, по мнению Аж. Стиглица, стала реализация либеральных реформ [Стиглиц Аж., 2003]. Критическое падение промышленного произвоАства было обусловлено и финансовыми трудностями, и отсутствием государственной инновационной и промышленной политики ${ }^{3}$, и “сформировавшимся в периоА реформ отечественным механизмом инвестирования, который в качестве главной цели ставил максимизацию прибыли, тем самым оказался в подчинении денежно-финансовых потоков, сконцентрированных в спекулятивно-посреднической сфере, отрегулированных по законам монетаризма и обусловивших спаА инвестиций и инноваций в реальном секторе экономики" [Аовбий И. П., 2011, с. 12].

Перенакопление финансового капитала привело к лисбалансу между уровнем и характером развития производительных сил, с оАной стороны, и произвоАственно-финансовых отношений - с Аругой. Наибольшую угрозу Аля национальной экономики стали преАставлять Аеформированная структура производственных мощностей, их несопряженность и неАостаточность в различных отраслях экономики и инфраструктуры.

Следует подчеркнуть, что Аля экономически развитого государства промышленность выступает гарантом обеспечения экономической безопасности, являясь базовой составмяющей экономики. России крайне важно преодоление беспрецедентного падения национальной экономики, наблюАавшееся в 1990-х, когАа промышленное производство упало в 1998 г. Ао 48,2 \% от уровня 1991 г. (рис. 1). На фоне кратных потерь профессиональных калров, износа основных фондов исчезли целые секторы промышленности, что запустило механизмы деформации и деградации структур управления экономикой [Аовбий И. П., 2018].

Рисунок 1

\section{Аинамика промышленного производства в Российской Федерации, в \% к 1991 г. / Dynamics of the industrial production in the Russian Federation, in \% by 1991

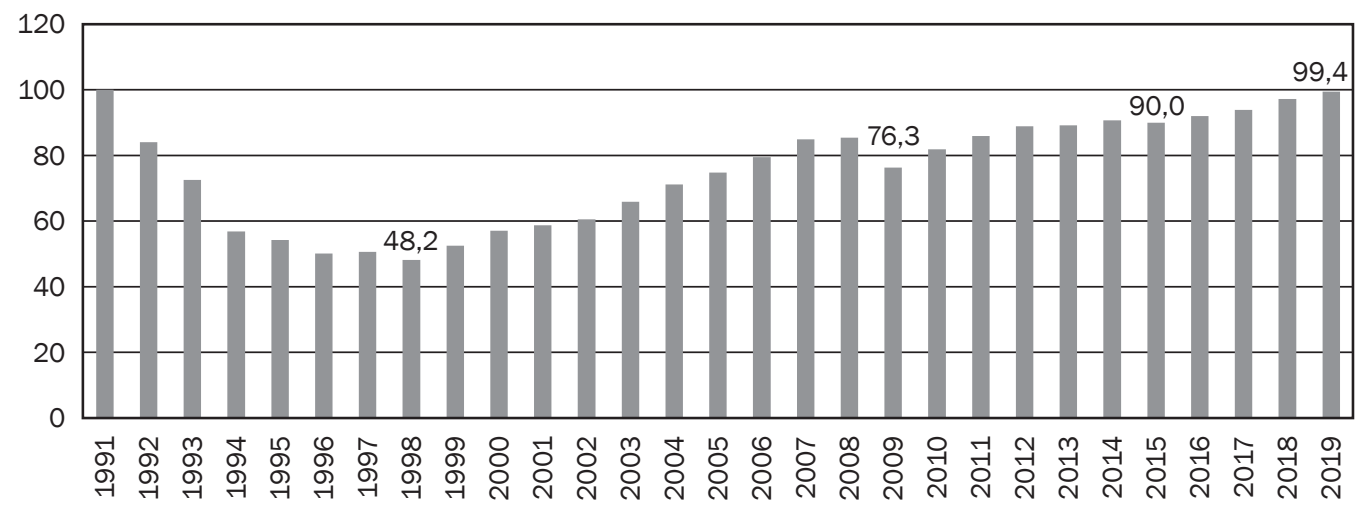

Источник: расчеты авторов на основе официальных данных Росстата / Source: authors' calculations based on the official data of the Federal State Statistic Service.

Алительное восстановление экономики сопровождалось кризисами (1998 г., 2008 г.) и, наконец, в 2014-2015 гг. затормозилось введенными против России экономическими санкциями, закрепившими отставание от развитых и ухудшение положения относительно

\footnotetext{
з С учетом последствий глобального кризиса перед экспертным сообществом была поставлена задача переосмысления социально-экономической политики России, перехода от “экономики спроса" К “экономике предложения" и выработки обновленной стратегии развития до 2020 г.
} 
развивающихся государств: в основе экспорта - продукция низких переделов; импорт хотя и ориентирован на высокотехнологичную продукцию (в станкостроении Аостигает 70-80 \%), однако не обеспечивает потребности национальной экономики в новейших технологиях. В 2019 г. национальная экономика практически вышла на уровень начала 1990-х (99,4 \% к 1991 г.), однако на фоне карантинных ограничений, вызванных COVID-19, промышленный рост прервался.

В условиях системного экономического кризиса и деградации национальной экономики достаточно четко обозначилась системная проблема: Аля защиты национальных интересов и нейтрализации новых вызовов и угроз необходимо было осмысление и стратегическое самоопределение. Проблема выбора новой стратегии долгосрочного экономического роста с учетом требований устойчивого развития стала фактором экономической безопасности государства. ОАнако, по мнению А. Амосова, «прежде чем вступить в фазу экономического роста, необходимо восстановить производство Ао уровня, Аостигнутого переА спаАом" [Амосов А., 2015]. Особое значение, по мнению А. Татаркина и О. Романовой, играет государственная промышленная политика, требующая баланса сугубо экономических и социальных целей развития [Татаркин А. И., Романова О. А., 2014)].

Формирование институциональной среАы российской промышленности в периоА с 1989 г. (начала стихийной приватизации и отсутствия промышленной политики как таковой) и по настоящее время осуществлялось на основе различных интересов и отношений, складывающихся между властными структурами, бизнесом и прочими сторонами. В различные периоды менялись содержание и приоритеты промышленной политики (табл. 1).

Таблица 1

\section{Институциональная среда развития российской промышленности (1989-2020 гг.) / Institutional environment of the Russian industry development (1989-2020)}

\begin{tabular}{|c|c|c|c|}
\hline Период & $\begin{array}{c}\text { Содержание и приоритеты } \\
\text { промышленной политики }\end{array}$ & Интересы и отношения & Итоги реализации \\
\hline $\begin{array}{l}1989- \\
1991 \text { гг. }\end{array}$ & $\begin{array}{l}\text { Промышленная политика } \\
\text { не проводится, "рынок - } \\
\text { панацея от всех беА" }\end{array}$ & $\begin{array}{l}\text { Подготовка к приватизации, } \\
\text { утрата государством интереса } \\
\text { к промышленности; } \\
\text { основной интерес к развитию } \\
\text { промышленных предприятий } \\
\text { проявляют чиновники и “красные } \\
\text { Аиректора», привыкшие распре- } \\
\text { делять наиболее дефицитную } \\
\text { продукцию и желающие закрепить } \\
\text { статус-кво }\end{array}$ & $\begin{array}{l}\text { Аеградация технологической и } \\
\text { отраслевой структуры производства }\end{array}$ \\
\hline $\begin{array}{l}1992- \\
1993 \text { гг. }\end{array}$ & $\begin{array}{l}\text { Радикальная } \\
\text { экономическая реформа; } \\
\text { утрата возможностей } \\
\text { централизованного } \\
\text { управления экономикой; } \\
\text { селективная подлержка } \\
\text { приоритетных отраслей, } \\
\text { конверсионные кредиты, } \\
\text { действие рыночных } \\
\text { рычагов принимает } \\
\text { «извращенные» формы }\end{array}$ & \multirow{2}{*}{$\begin{array}{l}\text { Аоминирование идеи о рыночной } \\
\text { экономике; } \\
\text { "Аикая" приватизация и ослабле- } \\
\text { ние государственных интересов } \\
\text { в общей системе интересов, } \\
\text { понижение роли государства } \\
\text { в решении вопросов устойчивого } \\
\text { промышленного развития; } \\
\text { потеря контрагентов из бывших } \\
\text { союзных республик; } \\
\text { Аисбалансы и Аиспаритеты на } \\
\text { всех уровнях экономики; } \\
\text { институциональный конфликт } \\
\text { интересов на фоне оппортунисти- } \\
\text { ческого поведения бизнес-элит, } \\
\text { как следствие - разрушение про- } \\
\text { мышленного потенциала, утрата } \\
\text { целых секторов экономики (станко- } \\
\text { строения, электроники и др.) }\end{array}$} & $\begin{array}{l}\text { Неэффективность Аеятельности, } \\
\text { реструктуризация и банкротство } \\
\text { промышленных предприятий; } \\
\text { снижение Аинамики развития } \\
\text { НИОКР в большинстве отраслей; } \\
\text { развитие отношений ренты за счет } \\
\text { особых отношений между отдель- } \\
\text { ными представителями бизнеса } \\
\text { и государственных структур }\end{array}$ \\
\hline $\begin{array}{l}1994- \\
1998 \text { гг. }\end{array}$ & $\begin{array}{l}\text { Государственная } \\
\text { подАержка отдельных } \\
\text { эффективных рыночных } \\
\text { проектов; } \\
\text { возведение и падение } \\
\text { пирамиды ГКО }\end{array}$ & & $\begin{array}{l}\text { Отсутствие позитивных структурных } \\
\text { и технологических сАвигов, затухание } \\
\text { технологического прогресса в отдель- } \\
\text { ных отраслях промышленности; } \\
\text { потеря высококвалифицированного } \\
\text { кадрового потенциала промышлен- } \\
\text { ности, разрушение сферы професси- } \\
\text { онально-технического образования }\end{array}$ \\
\hline
\end{tabular}




\begin{tabular}{|c|c|c|c|}
\hline ПериоА & $\begin{array}{l}\text { Содержание и приоритеты } \\
\text { промышленной политики }\end{array}$ & Интересы и отношения & Итоги реализации \\
\hline $\begin{array}{l}1998- \\
2000 \text { гг. }\end{array}$ & $\begin{array}{l}\text { «^учшая промышленная } \\
\text { политика - отсутствие } \\
\text { промышленной политики»; } \\
\text { перенос налогового бремени } \\
\text { с высокотехнологичного на } \\
\text { экспортно-сырьевой сектор }\end{array}$ & $\begin{array}{l}\text { Восстановительный рост } \\
\text { обусловлен падением курса } \\
\text { рубля почти в } 4 \text { раза и наличием } \\
\text { свободных производственных } \\
\text { мощностей Аля замещения } \\
\text { промышленного импорта }\end{array}$ & $\begin{array}{l}\text { Консервация сложившейся } \\
\text { структуры промышленности: } \\
\text { на фоне падения курса рубля } \\
\text { увеличивается емкость рынка } \\
\text { продукции отечественной } \\
\text { промышленности }\end{array}$ \\
\hline $\begin{array}{l}2001- \\
2005 \text { гг. }\end{array}$ & $\begin{array}{l}\text { Режим мягкой регуляции } \\
\text { (горизонтальная промышлен- } \\
\text { ная политика), реализующей } \\
\text { универсальные методы } \\
\text { и инструменты подлержки } \\
\text { в рамках либеральной } \\
\text { модели экономического } \\
\text { развития (налоги, обменный } \\
\text { курс, тарифы естественных } \\
\text { монополий); } \\
\text { развитие рыночных } \\
\text { институтов }\end{array}$ & $\begin{array}{l}\text { Бизнес проявляет инициативу } \\
\text { и активность; } \\
\text { персонифицированность } \\
\text { отношений власти и бизнеса } \\
\text { принимает широкие обороты; } \\
\text { практика встреч с крупным } \\
\text { бизнесом; } \\
\text { прямые конфликты между } \\
\text { бизнес-группами, в которые } \\
\text { вовлекаются силовые } \\
\text { структуры; } \\
\text { государство - арбитр при } \\
\text { столкновении интересов }\end{array}$ & $\begin{array}{l}\text { Ограниченный рост, некоторое } \\
\text { улучшение условий развития } \\
\text { низкотехнологичных } \\
\text { производств; } \\
\text { снижение конкурентоспособ- } \\
\text { ности и разрушение потенциала } \\
\text { развития высокотехнологичных } \\
\text { производств }\end{array}$ \\
\hline $\begin{array}{l}2006- \\
2008 \text { гг. }\end{array}$ & $\begin{array}{l}\text { Аиверсификация, стимулиро- } \\
\text { вание инноваций; } \\
\text { Аополнение мягкой промыш- } \\
\text { ленной политики селективными } \\
\text { мерами господАержки приори- } \\
\text { тетных виАов Аеятельности } \\
\text { (вертикальная отраслевая } \\
\text { промышленная политика), } \\
\text { Аолгосрочное проектирование; } \\
\text { использование государст- } \\
\text { венной собственности } \\
\text { и бюАжетных средств }\end{array}$ & $\begin{array}{l}\text { Аемонстрация государством } \\
\text { наличия собственных интересов } \\
\text { в промышленности и создание } \\
\text { совета по конкурентоспособности } \\
\text { (институционализация Аоступа) } \\
\text { обозначили начало становления } \\
\text { конкурентной промышленной } \\
\text { политики; } \\
\text { построение иерархии и вертикали } \\
\text { власти, усиление государствен- } \\
\text { ного контроля на фоне роста } \\
\text { конкуренции между властными } \\
\text { элитами, в т. ч. через конт- } \\
\text { рольные органы, имели слеА- } \\
\text { ствием преобразование групп } \\
\text { интересов }\end{array}$ & $\begin{array}{l}\text { Быстрый сырьевой рост } \\
\text { и существенные бюАжетные } \\
\text { ресурсы; акцент на развитие } \\
\text { инновационного потенциала } \\
\text { и высокотехнологичных } \\
\text { производств; } \\
\text { реализация национальных } \\
\text { проектов; создание государст- } \\
\text { венных корпораций и концент- } \\
\text { рация финансовых ресурсов } \\
\text { в институтах развития }\end{array}$ \\
\hline $\begin{array}{l}2009- \\
2011 \text { гг. }\end{array}$ & $\begin{array}{l}\text { Антикризисная политика, } \\
\text { контроль цен, «ручное" } \\
\text { управление (установление } \\
\text { преференций), направленное } \\
\text { на модернизацию и } \\
\text { Аиверсификацию экономики; } \\
\text { меры стимулирования } \\
\text { внутреннего спроса на } \\
\text { промышленную продукцию; } \\
\text { выравнивание конкурентных } \\
\text { условий Аля отраслей добыва- } \\
\text { ющей и перерабатывающей } \\
\text { промышленности }\end{array}$ & $\begin{array}{l}\text { Обеспечение социальной } \\
\text { стабильности; } \\
\text { помощь в обмен на обязатель- } \\
\text { ства между государством } \\
\text { и крупным бизнесом; } \\
\text { расширение конкуренции } \\
\text { в сфере Аоступа к власти } \\
\text { (презилентская и правитель- } \\
\text { ственная комиссии), усиление } \\
\text { давления контрольных органов; } \\
\text { новые формы взаимодействия } \\
\text { с бизнесом, в т. ч. подключение } \\
\text { регуляторов (финансовых, } \\
\text { налоговых и проч.) Аля воздей- } \\
\text { ствия на бизнес в социанно } \\
\text { чувствительных сферах; } \\
\text { расширение состава субъектов } \\
\text { формирования промышленной } \\
\text { политики (финансовые и } \\
\text { нефинансовые институты } \\
\text { развития, уполномоченные } \\
\text { банки, крупные промышленные } \\
\text { предприятия, субъекты малого } \\
\text { и среднего бизнеса, инноваци- } \\
\text { онные бизнес-инкубаторы, } \\
\text { центры трансфера технологий, } \\
\text { технологические и промышлен- } \\
\text { ные парки и проч.) }\end{array}$ & $\begin{array}{l}\text { Структурная модернизация } \\
\text { отечественной экономики } \\
\text { с опережающим развитием } \\
\text { высокотехнологичных } \\
\text { производств; } \\
\text { повышение престижности } \\
\text { труда в отраслях материального } \\
\text { производства }\end{array}$ \\
\hline
\end{tabular}




\begin{tabular}{|c|c|c|c|}
\hline Период & $\begin{array}{l}\text { Содержание и приоритеты } \\
\text { промышленной политики }\end{array}$ & Интересы и отношения & Итоги реализации \\
\hline $\begin{array}{l}\text { С } 2012 \\
\text { по } 2014 \text { г. }\end{array}$ & $\begin{array}{l}\text { Технологическая политика } \\
\text { «новой индустриализации"; } \\
\text { "дорожные карты"; } \\
\text { ужесточение бюАжетных } \\
\text { ограничений; } \\
\text { ставка на налоговые маневры, } \\
\text { реиндустриализацию, } \\
\text { улучшение инвестиционного } \\
\text { климата }\end{array}$ & $\begin{array}{l}\text { Появление новых игроков, } \\
\text { предложение новых мер, поиск } \\
\text { новых групп подАержки политики; } \\
\text { Аискуссии по содержанию, } \\
\text { мерам и направлениям } \\
\text { "новой индустриализации"; } \\
\text { создание новых механизмов } \\
\text { коммуникации (открытое } \\
\text { правительство), частичное } \\
\text { дерегулирование, передача } \\
\text { части полномочий регионам }\end{array}$ & $\begin{array}{l}\text { Существенное замеАление } \\
\text { роста, усиление бюАжетных } \\
\text { ограничений; созАание } \\
\text { новых секторов экономики, } \\
\text { инновационное обновление } \\
\text { традиционных производств, } \\
\text { создание высокопроизво- } \\
\text { Аительных рабочих мест }\end{array}$ \\
\hline $\begin{array}{l}2015- \\
2017 \text { гг. }\end{array}$ & $\begin{array}{l}\text { Политика импортозамещения; } \\
\text { работа в условиях санкций } \\
\text { обеспечила изменение } \\
\text { условий Аля формирования } \\
\text { промышленной политики после } \\
\text { вступления в ВТо }\end{array}$ & $\begin{array}{l}\text { Ограничения на рынке капитала: } \\
\text { высокая ключевая ставка, } \\
\text { невозможность привлечения } \\
\text { зарубежных кредитов; } \\
\text { ограничения рынка технологий } \\
\text { и высокотехнологичного } \\
\text { оборудования }\end{array}$ & $\begin{array}{l}\text { Преодоление зависимости } \\
\text { от импорта технологий; } \\
\text { формирование умеренно } \\
\text { сбалансированной } \\
\text { экономики }\end{array}$ \\
\hline $\begin{array}{l}\text { C } 2018 \text { г. } \\
\text { по н. в. }\end{array}$ & $\begin{array}{l}\text { Политика внедрения } \\
\text { наилучших доступных } \\
\text { технологий }\end{array}$ & $\begin{array}{l}\text { Формирование нормативной } \\
\text { правовой базы и основных прин- } \\
\text { ципов экологической промыш- } \\
\text { ленной политики, системы } \\
\text { показателей макроуровня Аля } \\
\text { оценки результатов перехода на } \\
\text { принципы наилучших Аоступных } \\
\text { технологий (НАТ), отраслевых } \\
\text { методик оценки затрат перехода } \\
\text { на принципы НАТ; } \\
\text { поддержка государством } \\
\text { "зеленыХ" проектов через } \\
\text { механизм возмещения затрат } \\
\text { на выплату купонного дохода }\end{array}$ & $\begin{array}{l}\text { Кардинальное снижение } \\
\text { уровня негативного } \\
\text { воздействия на } \\
\text { окружающую среду; } \\
\text { снижение доли импорта } \\
\text { основного технологического } \\
\text { оборудования, эксплуатиру- } \\
\text { емого в случае применения } \\
\text { наилучших доступных } \\
\text { технологий, с } 50 \text { \% в } 2019 \text { г. } \\
\text { до } 36 \% \text { к } 2024 \text { г.; } \\
\text { развитие промышленности } \\
\text { и повышение ее конкуренто- } \\
\text { способности }\end{array}$ \\
\hline
\end{tabular}

Источник: составлено авторами по [Акбердина В., 2017; Аовбий И. П., 2018; Кузнецов Б. В., Симачев Ю. В., 2014; Симачев Ю., 2014; Татаркин А. И., Романова О. А., 2014)] / Source: compiled by the authors based on [Akberdina V., 2016; Dovbiy I.P., 2018; Kuznetsov B.V., Simachev Yu.V., 2014; Simachev Yu., 2014; Tatarkin A.I., Romanova O.A., 2014].

Первый этап условно можно обозначить периодом 1989-1991 гг., связанным со стихийной приватизацией, утратой государством интереса к промышленности и переходом инициативы к "красным директорам", желающим удерживать руководящие позиции и контроль наА преАприятиями.

Следующие несколько этапов были обусловлены началом в 1992 г. рыночных реформ, официальной приватизацией, утратой государством способности централизованного управления экономикой, кризисом неплатежей в экономике и банкротством крупных промышленных преАприятий. СлеАствием стало разрушение промышленного потенциала национальной экономики.

Кризис 1998 г., с одной стороны, нанес существенный удар по национальной промышменности, с Аругой, - на фоне четырехкратной девальвации национальной валюты открыл окно восстановительного промышленного роста на свободных производственных мощностях. Период с января 2001 г. по август 2008 г. рассматривается как периоА "тучных лет", обеспечивших построение "вертикали власти", восстановление государством собственных интересов в промышленности и проведение мягкой промышленной политики.

Мировой финансовый кризис, обострившийся в сентябре 2008 г., имел слеАствием введение "ручного" антикризисного управления, направленного на модернизацию национальной промышленности и начало процесса формирования промышленной политики на основе взаимодействия государства, бизнеса и науки. 
С 2012 г. начинается восстановительный рост, обусловленный инновационным обновлением промышленности, прежде всего предприятий оборонно-промышленного комплекса. Обретает очертания технологическая политика "новой индустриализации". После Конференции ООН 2012 г. на повестку Аня встала задача "экологизации" экономики через моАернизацию производства. В качестве совокупности форм регулирования и ресурсов Аля реализации инвестиционных и инновационных инициатив в 2014 г. была принята ЕАиная промышленная политика ${ }^{4}$, а также определены условия Аля регионов, обеспечивающих принятие и реализацию рамочных законов о промышленной политике и Аетерминирующих Аолгосрочные стратегические приоритеты промышленного развития ${ }^{5}$. В 2015 г. Федеральным законом № 219-Ф3 принято решение о созАании механизма наилучших Аоступных технологий (НАТ) на технологии, обеспечивающие в том числе снижение экологической нагрузки. Несколько ранее в презилентском указе 2008 г. были закреплены требования энергетической и экологической эффективности хозяйствующих субъектов национальной экономики?

С подписанием Парижского соглашения в декабре 2015 г. Россией были установлены целевые ориентиры снижения к 2030 г. выбросов парниковых газов Ао 70-75 \% от уровня выбросов 1990 г. В 2017 г. Аанный показатель приблизился к 34 \%, однако это скорее стало следствием Алительного спада в экономике. Согласно Аанным аналитического центра при Правительстве Российской Федерации, в 2018 г. "совокупный объем выбросов загрязняющих веществ в атмосферу состави^ 32,3 млн т, из которых 17,1 млн т выброшено стационарными источниками".

В 2018 г. политика внеАрения НАТ Аля преАприятий-загрязнителей получает нормативно-правовое обеспечение 9 и становится связующим компонентом промышленной и экомогической политики государства и базой "новой индустриализации". В декабре 2019 г. Распоряжением Правительства РФ был утвержден Национальный план мероприятий первого этапа адаптации к изменениям климата на период Ао 2022 г., в котором указывалось, что часть территории страны находится в области значительных (наблюдаемых и прогнозируемых) изменений климата, послеАствия которых существенно воздействуют на социально-экономическое развитие государства, качество жизни населения, экономическую активность хозяйствующих субъектов.

Таким образом, ориентация на "озеленение" национальной промышленности началась лишь на последних этапах институционального оформления промышленной политики, окончательно обозначивших необходимость "новой индустриализации".

Являясь членом G20, Россия в вопросе устойчивого социально-экономического развития подАержала решение группы о приоритетном значении "зеленого" развития не только на макро-, но и на мезоуровне. Траектория Авижения России к "зеленой" экономике будет характеризоваться крайней нелинейностью по причине существенной неоднороАности экономического развития регионов как вслеАствие территориальной отАаленности, инфраструктурной и институциональной необеспеченности, наличия/отсутствия различных ресурсов, включая человеческий капитал, так и в силу накопившихся экологических Аисбалансов и проблем.

\footnotetext{
Федеральный закон от 31.12.2014 № 488-Ф3 "О промышленной политике в Российской Федерации".

К 2000 г. только в 15 субъектах Федерации имелись законы о промышленной политике.

6 Федеральный закон Российской Федерации № 219-Ф3 от 21 июля 2014 г. "О внесении изменений в Федеральный закон “Об охране окружающей среды и отдельные законодательные акты Российской Федерации”.

7 Указ Президента РФ № 889 от 04.06.2008 “О некоторых мерах по повышению энергетической и экологической эффективности российской экономики".

8 https://ac.gov.ru/files/publication/a/23719.pdf.

9 Приказ Минприроды России от 18.04.2018 № 154 “Об утверждении перечня объектов, оказывающих негативное воздействие на окружающую среду, относящихся к I категории, вклаА которых в суммарные выбросы, сбросы загрязняющих веществ в Российской Федерации составляет не менее чем 60 процентов".
} 
Кроме того, необходимо учитывать, что современная практика формирования промышменной политики в развитых и Аинамично развивающихся странах указывает на устойчивые тренды, обуславливающие актуальность выбора приоритетов развития. Речь идет о высокой неопределенности внешней среды и волатильности процессов в экономике, существенном усложнении цепей добавленной стоимости, исчерпании потенциала институционального регулирования, усилении экологизации экономики, поколенческих изменениях, изменениях бизнес-моделей и форм организации с ориентацией на сетевые формы взаимодействия [Аовбий И. П., 2018].

\section{"ЗЕАЕНЫЕ" ПРИЗНАКИ “НОВОЙ ИНАУСТРИААИЗАЦИИ"}

K началу 2020-х гг. Россия подошла с критически изношенными основными фондами. За последние тридцать лет степень износа не только не снизилась, но и возросла с 35,6 \% в 1990 г. Ао 46,8 \% в 2019 г. Коэффициент обновления снизился, соответственно, с 6,3 Ао 4,6 \%; коэффициент выбытия - с 2,4 до 0,7 \% ${ }^{10}$. Кардинальное обновление основных фонАов в течение послеАних Аесяти лет наблюАалось только в оборонно-промышленном комплексе. В обрабатывающей промышленности активность в обновлении основных фонАов началась с 2000-х гг., и в настоящий момент среАний срок службы оборудования составляет около 23 лет. При этом в ^юбой отрасли оАновременно присутствуют как принципиально новые, оснащенные конкурентоспособными технологиями преАприятия, так и преАприятия с существенной Аолей устаревших фондов.

В условиях усиливающейся глобальной конкуренции и широкого внедрения развитыми странами экологических стандартов Аля России критически важно в кратчайшие сроки преоАолеть послеАствия Алительной стагнации промышленности и обеспечить ее техникотехнологическую модернизацию.

Запуск системы расширенного инновационного воспроизводства национальной экономики возможен посредством механизмов "новой индустриализации". ОАнако Аля этого необходимы политическая воля руководства страны и политические решения, которые закрепят "новую индустриализацию" в национальной стратегии развития, законодательных и нормативно-правовых актах.

А пока понятие "новая индустриализация" активно обсуждается ведущими российскими учеными (С. А. Бодруновым, С. Ю. Глазьевым, Р. С. Гринбергом, С. С. Губановым, В. М. Кульковым, Е. Б. Аенчук, О. С. Сухаревым и Ар.), прочно закрепилось в отечественном лексиконе политиков, экономистов, финансистов и подразумевает возрождение отечественного индустриального производства. В зарубежных странах термин "новая индустриализация" имеет иной смысл: возврат "на национальные территории индустриальных производств, размещенных ранее в странах с низкой ценой труда" [Кульков В. М., 2015].

В отечественных исследованиях термин "новая индустриализация" отождествляется C "реиндустриализацией", "неоиндустриализацией", "сверхиндустриализацией", что преАставляется ошибочным. О необходимости обособления этих понятий говорится в исслеАовании В. М. Кулькова:

- "реиндустриализация" рассматривается в качестве выражения ориентира и инАустриального курса российской экономики Аля формирования надежной материальнотехнической базы как основы национального суверенитета, а также комплекса мер Аля преодоления стремительной Аеиндустриализации 1990-х;

- "неоиндустриализация" опреАеляет переход российской экономики на новый индустриальный базис четвертого и пятого технологических уклаАов, знаменующих переход к высокотехнологичному наукоемкому производству;

\footnotetext{
10 Коэффициенты обновления и выбытия основных фондов. URL: https://www.gks.ru/folder/14304.
} 
- "сверхиндустриализация" увязывается с опережающим развитием, Четвертой промышленной революцией, переходом к шестому технологическому укладу, изменением содержания труда и экономической деятельности на основе NBIC-технологий;

- "новая индустриализация" - явление интегральное, вбирающее в себя "реиндустриализацию", "неоиндустриализацию" и "сверхиндустриализацию", означает Аля России необхолимость воплощения всех трех стратегий: “восстановление, Аинамическое наверстывание и опережающее развитие» [Кульков В. М., 2015].

Согласимся с изложенной позицией, поскольку нам представляется, что «реиндустриализация" отожАествляется с переходом экономики к расширенному воспроизводству; "неоинаустриализация" - к расширенному интенсивному воспроизводству; "сверхинАустриализация" - к расширенному инновационному воспроизводству. "Новая индустриализация" Аолжна отражать общемировой тренд К "зеленой" экономике, то есть расширенное инновационное воспроизводство на основе "зеленых" технологий.

Какой тип общественного воспроизводства определяет "новая индустриализация" Аля национальной экономики? Прежде всего необходимо выделить основные черты “новой индустриализации" в России:

- наукоемкая экономика, характеризующаяся трудосбережением, рециркуляцией ресурсов, безотходностью производства, превращением общественного труда прежде всего в творческий и организационный [Губанов С., 2017];

- основывается на обрабатывающей промышленности, обладающей наибольшим в экономике мультипликативным эффектом: 1 Аолм. США вложений в Аанную сферу экономики способствует росту ВВП на 1,5 Аомм., а созАание оАного рабочего места увеличению занятости на 0,5-2 рабочих места в Аругих секторах [Толкачев С., 2014];

- имеет свои цели (создание производительных сил технотронного уровня), задачи (внеАрение в производство Аостижений четвертой промышленной революции), формы организации по вертикали и горизонтали (межтерриториальные сетевые структуры, госуАарственно-частное партнерство и т. А.), свои движущие силы (взаимодействие государства, фундаментальной, прикладной науки, образования и бизнеса) [Силин Я. П. и Ар., 2017];

- означает превращение раздробленного ныне народного хозяйства в консолидированную экономику, качественно схожую с экономикой передовых индустриальных стран мира [Кульков В. М., 2014];

- нацелена на создание качественно новых производительных сил технотронного уровня, взаимосвязанных в системе автоматизированных машин [Сухарев О. С., 2013];

- базируется на технологиях пятого и шестого технологических укладов [Глазьев С. Ю., Харитонов В. В., 2009; Аенчук Е. Б., 2014];

- является цифровой и технотронной [Губанов С., 2017], основывается на вертикальной интеграции корпораций (в триаде “наука - Аобывающие производства - обрабатывающие производства"), не Аопускающей изъятие прибыли на стадии добычи сырья или производства полуфабрикатов [Губанов С., 2008];

- обеспечивает ведущую роль реального сектора экономики с приоритетностью производственного капитала над финансовым и суверенную политику государства [Рязанов В. Т., 2016].

Кроме того, прогрессивные технологии в сферах программного обеспечения и 3D-печати положили начало формированию новой аАдитивной парадигмы («глобальный Аизайн - локальное производство"), базирующейся на эффекте масштаба и системе углубления разАеления труда и открывающей широкие перспективы развития революции в области обрабатывающей промышленности [Толкачев С. А., 2018]. Будучи компонентом промышленной политики, "новая индустриализация" Аолжна осуществляться "В неразрывной связи с последовательными прогрессивными изменениями политических 
и институциональных основ общества, индивидуального и общественного сознания, целеустремленным решением прогрессирующих социально-экономических и экологических проблем" [АрозАов О. А., 2014, с. 28].

Названное является Аалеко не полным перечнем признаков и критериев, которым Аолжна соответствовать "новая индустриализация", формирующая новый тип производительных сил и новое качество производственных отношений. На наш взгляА, Аля России она не имеет смысла без "зеленых" технологий, а "зеленая" экономика невозможна без «новой индустриализации".

Обозначим лишь несколько аспектов, отражающих Аиалектическое еАинство процессов "новой индустриализации" и "озеленения" экономики.

Первое. Перехол к "зеленой" экономике является безальтернативным процессом, объективно обусловленным требованием снижения экологических рисков и обеспечения социального равенства, повышения благосостояния, сохранения человеческой цивилизации. Россия - активный субъект на международной арене - подАержала Аокумент "Повестка Аня в области устойчивого развития на период Ао 2030 года" [United Nations, 2015], определивший 17 целей (SDGs). В отношении промышленных преАприятий речь илет о том, чтобы ускорить переход к углеродно-нейтральной экономике за счет снижения энергопотребления и более экологичных решений. ПреАприятиям промышленности преАстоит отчитываться по целому ряду экологических индикаторов: выбросам в атмосферу и сточным водам; потреблении и экономии топлива, энергии, воды; опасным и неопасным отходам, повторно используемым, размещенным и переработанным; суммам расходов на охрану окружающей среды и т. А. В последние годы ведется активная работа по гармонизации российского законодательства в области охраны окружающей среды с европейским. В связи с накопившимися экологическими проблемами с 2020 г. промышменные предприятия России переходят на новую систему регулирования загрязнения окружающей среды, которая применяется и положительно зарекомендовала себя в странах ЕС. Таким образом, “новая индустриализация" Аолжна соответствовать принципам "зеленой" экономики, при которой экологическое регулирование Аополняется принципами устойчивого развития и "зеленого" роста.

Второе. “Новая индустриализация" Аолжна ориентироваться на экспорт, но будет проводиться в условиях возрастающей конкуренции между государствами, практики протекционизма и взаимных торговых ограничений. В качестве примера можно привести "Аизельгейт" (Германия), "Северный поток" (Россия). Так, строительство и эксплуатация "Северного потока" считались практически эталоном в контексте соблюАения требований экологической безопасности, однако "Северный поток-2" Аолжен также соответствовать нормам Третьего энергопакета и законам ЕС в области энергетики, конкуренции и внутреннего рынка. Соответственно, внеАрение экологических стандартов и "зеленых" технологий Аля преАприятий индустриального сектора является еАва ли не базовым фактором будущей конкурентоспособности на мировых рынках. Кроме того, усиление напряженности межАу ведущими экономическими державами увеличивает риск Аевальвации веАущих мировых валют [Мантуров А. В., 2018], что может привести к "валютным войнам" и углублению дисбалансов в мировой торговле.

Третье. Россия столкнется с глобальными рисками постоянного принятия новых санкций, что ограничит Аоступ к рынкам сбыта, международным инвестициям и финансовому капиталу; усилится политическое Аавление и барьеры трансфера технологий. Политика "новой индустриализации" Аолжна рассматриваться в единстве с политикой экономической безопасности, учитывая исторический опыт внешнеполитических вызовов. В частности, можно упомянуть Аолгосрочный Аоговор “газ-труба" между СССР и ФРГ, предусматривающий импорт магистральных труб большого диаметра в обмен на экспорт газа. Поставку труб Аиаметром 1020 мм Аолжны были осуществлять компании Krupp, Mannesmann 
и Phoenix-Rheinruhr. ОАнако поА Аавлением США правительство К. ААенауэра ввело запрет на выполнение контрактов, и немецкие компании потерпели колоссальные убытки. На Челябинском трубопрокатном заводе началось строительство стана "1020". Стройка получила статус всесоюзной и была завершена Аосрочно, в аАминистративном порядке получив от государства необходимые ресурсы. Исторический опыт показывает: высокая вероятность ограничений на обмен технологиями и компетенциями с иностранными производителями Аиктует необходимость УАелить особое внимание совершенствованию не только фундаментальных, но и прикладных НИОКР, а также системы поАготовки высококвалифицированных калров. В условиях рыночных отношений Аолжна быть создана среАа, обеспечивающая стратегическое взаимодействие и совместное решение проблем промышленности агентами частного и государственного секторов.

Четвертое. Накопившиеся проблемы национальной промышленности нашли отражение в майском Указе Президента России ${ }^{11}$, определившем необходимость Аиверсификации промышленности и формирования "в обрабатывающей промышленности глобальных конкурентоспособных несырьевых секторов, общая Аоля экспорта товаров (работ, услуг) которых составит не менее 20 \% валового внутреннего продукта страны", что означает "опережающие темпы роста промышленного производства по отношению к Аругим отраслям экономики" на уровне не менее 4 \%” [Мантуров А. В., 2018, с. 15].

Пятое. Четвертая промышленная революция, характеризующаяся интенсивным развитием конвергентных технологий, кластерных и сетевых форм структурирования бизнеса, беспрецедентно меняет роль человеческого капитала. Непрерывное технологическое обновление производств будет предъявлять новые требования к воспроизводству высокоинтемлектуальных производительных сил, вовлекая человеческий капитал в процесс развертывания "новой индустриализации" и формируя новые производственные отношения.

Шестое. "Новая индустриализация" предполагает существенные инвестиции. Скорее всего, эти инвестиции не просто должны быть направлены на финансирование инновационных технологических разработок, но и должны носить ресурсосберегающий, экологоориентированный характер. Это означает, что отАельные предприятия-загрязнители неизбежно столкнутся с необходимостью привлечения инвестиций на финансовых рынках, в том числе на глобальных. ОАним из важнейших критериев инвестиционной привлекательности промышленного предприятия станет безусловное снижение негативного возАействия на окружающую среду. Эти же критерии будут применяться и к инструментам, обеспечивающим финансирование "новой индустриализации".

К сказанному следует Аобавить еще рял позиций, определяющих условия и факторы "новой индустриализации" в России:

- приоритетное развитие реального сектора экономики на новейшей технологической основе;

- формирование новой технократической элиты с компетенциями интемлектуального обеспечения новой политики;

- наращивание интемлектуального потенциала научных и инженерно-технических калров, реализующих новые научные направления и разработки конкурентных технологий;

- включение параметров "новой индустриализации" в состав ключевых стратегических задач государства ${ }^{12}$ с соответствующим законодательным, институциональным, финансовым и калровым обеспечением;

\footnotetext{
11 Указ Президента России от 7 мая 2018 г. № 204 "О национальных целях и стратегических задачах развития Российской Федерации на период до 2024 года".

${ }^{12}$ В процессе либеральных реформ основу целеполагания российской экономики составили финансовая стабильность и максимизация прибыли.
} 
- соответствие принципам устойчивого развития с опорой на эффективно функционирующие формальные и неформальные институты;

- наращивание кадрового потенциала с новым качеством рабочей силы Аолжно поААерживаться аАекватными социально-экономическими инструментами стимулирования работников и регулирования рынка труда, обеспечивая качественное воспроизводство человеческого капитала.

Таким образом, исследование различных факторов, условий и требований, которым Аолжна соответствовать проводимая государством промышленная политика, позволяет саелать вывод о том, что "новая индустриализация" выступает базисом не просто новой модели экономики, но и нового качества развития производительных сил, производственных отношений и нового типа воспроизводства экономических систем - расширенного "зеленого" воспроизводства.

\section{ЗАКАЮЧЕНИЕ}

В качестве итогов исследования сформулируем сначала основной вывоА: неолиберальная эпоха исчерпала резервы роста, что побуждает страны задумываться о новой моАели развития, при этом подходы К конкретному содержанию "новой индустриализации" могут существенно отличаться в различных странах. А^я России "новая индустриализация" Аолжна сочетать в себе черты четвертой промышленной революции с вектором Авижения к "зеленой" экономике. Аанное заключение можно подтверАить следующими положениями.

1. Переход к шестому технологическому укладу в большинстве стран сопряжен с принципами устойчивого развития и "зеленой" экономики.

2. Мировой кризис 2020 г. сглаАил проблему глобального перепроизводства и получил формат структурного кризиса, прежде всего вслеАствие принятия беспрецеАентных карантинных мер и массовой остановки предприятий в большинстве стран мира. После снятия ограничений, скорее всего, продолжится структурный спаА, порожАающий усиление требований "экологических" стандартов; последние могут стать мощным инструментом конкурентной борьбы компаний и государств.

3. Авижение России к "зеленой" экономике идет с существенным запаздыванием, однако в последние годы в стратегических документах были сформулированы меры, направленные на преодоление послеАствий Алительного простаивания промышленности и обеспечение ее технико-технологической модернизации. Начинается институциональное оформление "новой индустриализации" как механизма перехода национальной экономики к расширенному инновационному производству на принципах "зеленой" экономики.

4. Таким образом, исследование основных факторов, условий, трендов, требований и признаков "новой индустриализации", которая Аолжна быть проведена именно в России, позволило обобщить ее основные черты и сделать вывод о Аиалектическом еАинстве процессов "новой индустриализации" и "озеленения" экономики. 


\section{"Новая индустриализация" В России как фактор перехода к "зеленой" экономике}

\section{Список источников}

Акбердина В. Бюджет как направляющая основа социально-экономического развития индустриального региона, 2017. URL: https://www.iep.ru/ru/gaydarovskie-chteniya/17-02-2017-gaidarovskie-chteniia-v-ekaterinburge. html.

Амосов А. Можно ми отложить до 2017 г. поворот к новому индустриальному развитию // Экономист. 2015. № 3. C. 3-13.

Белов В. Б. COVID-19 - game changer европейской экономики? // Научно-аналитический вестник ИЕ РAН. 2020. № 3. С. 4-12.

Губанов С. Неоиндустриализация плюс вертикальная интеграция (О формуле развития России) // Экономист. 2008. № 9. С. 3-27.

Губанов С. Неоинаустриализация: к вопросу о “вопросе» (некоторые уточнения) // Экономист. 2017. № 3. С. $43-53$.

Аовбий И. П. Принципы кредитного обеспечения инвестиционно-инновационных процессов региона: моногр. Челябинск: ИзАательский центр ЮУргУ, 2011. 259 с.

Аовбий И. П. Промышленность России: инвестиционно-инновационное развитие и экономическая безопасность: моногр. Челябинск: ИзАательский центр ЮУрГУ, 2018. 240 с.

АрозАов О. А. К вопросу об ориентирах новой индустриализации в России / Новая индустриализация России. Теоретические и управленческие аспекты: моногр. ПоА научн. реА. Н. Ф. Газизулиина. СПб.: НПК "РОСТ", 2014.

Кабир ^. С. Социально ответственное инвестирование: тренд или временное явление? // Экономика. Налоги. Право. 2017. № 4. С. 35-41.

Кузнецов Б. В., Симачев Ю. В. Эволюция государственной промышленной политики в России. Журнал Новой экономической ассоциации. 2014. № 2 (22). С. 152-178.

Кульков В. М. Новая индустриализация в контексте экономического развития России // Экономика. Налоги. Право. 2015. № 2. С. 81-85.

Кульков В. М. Постиндустриализация или новая индустриализация? // Проблемы современной экономики. 2014. № 3. С. 56-59.

^енчук Е. Б. Формирование кадрового потенциала Аля инновационной экономики // Экономическое возрожАение России. 2017. № 1 (51). С. 22-26.

Ленчук Е. Б. Роль “Новой инаустриализации" в формировании инновационной экономики России / Институциональная среда "новой индустриализации" экономики России: сб. М.: Институт экономики РАН, 2014. 264 c.

Мантуров А. В. О промышленной политике России на перспективу 2018-2030 гг. // Вестник МГИМОУниверситета. 2018. 4 (61). С. 7-22. URL: https://doi.org/10.24833/2071-8160-2018-4-61-7-22.

Нанотехнологии как ключевой фактор нового технологического уклада в экономике / Под реА. С. Ю. Глазьева и В. В. Харитонова. М.: Тровант, 2009. 304 с.

Паздникова Н. П., Глазкова Н. Г., Буреш А. C. COVID-19: влияние нового типа коронавирусной инфекции на национальную экономику // Экономика: вчера, сегодня, завтра. 2020. T. 10. № 2A. С. 169-177. URL: https:// doi.org/10.34670/AR.2020.21.54.015.

Промышленная политика в эпоху цифровой трансформации экономики: моногр. / Под реА. С. А. Толкачева. М.: KноРус, 2018. 204 c.

Рязанов В. Т. (Не)Реальный капитализм. Политэкономия кризиса и его послеАствий Аля мирового хозяйства и России. М.: Экономика, 2016. 695 с.

Силин Я. П., Анимица Е. Г., Новикова Н. В. Региональные аспекты новой индустриализации // Экономика региона. 2017. Т. 13. Вып. 3. С. 684-696. URL: https://doi.org/1010.17059/2017-3-4.

Сухарев О. С. Реиндустриализация России. Возможности и ограничения // Экономист. 2013. № 3. С. 6-12.

Стиглиц Аж. Глобализация. Тревожные тенденции / Пер. с англ. и прим. Г. Г. Пирогова. М.: Мысль, 2003. 300 с.

Симачев Ю. Промышленная политика в России: институциональные особенности, группы интересов, уроки на будущее. Аиспут-клуб Ассоциации независимых центров экономического анализа “Узлы экономической помитики". Москва, 16 января 2014 г. URL: https://www.econ.msu.ru/ext/lib/News/x20/x6e/8302/file/Simachev\% 20presentation\%202014-01.pdf.

Татаркин А. И., Романова О. А. Промышленная политика: генезис, региональные особенности и законодательное обеспечение // Экономика региона. 2014. № 2 (38). С. 9-21. URL: https://doi.org/10.17059/2014-2-1.

Толкачев С. Реиндустриализация в США: канун неоиндустриального уклада // Экономист. 2014. № 10. C. 54-69.

Transforming our world: the 2030 Agenda for Sustainable Development / United Nations, resolution A/RES/70/ 1, 2015.

Поступила в редакцию 11 июля 2020 г. Принята к публикации 19 августа 2020 г. 


\section{References}

Akberdina V. (2017). The Budget as a Guiding Basis for the Socio-Economic Development of an Industrial Region (In Russ.). Available at: https://www.iep.ru/ru/gaydarovskie-chteniya/17-02-2017-gaidarovskie-chteniiav-ekaterinburge.html.

Amosov A. (2015). Is It Possible to Postpone Until 2017 the Turn to New Industrial Development. Ekonomist The Economist, no. 3, pp. 3-13 (In Russ.).

Belov V. (2020). COVID-19 - Game Changer of the European Economy? Nauchno-analiticheskiy vestnik IYe RAN - Scientific and Analytical Heraldof the Institute of Europe RAS, no. 3, pp. 4-12 (In Russ.). Available at: http:// dx.doi.org/10.15211/vestnikieran32020412.

Dovbij I.P. (2011). The Principles of a Credit Provision for Investment and Innovative Processes in the Region: Monograph. Chelyabinsk: SUSU Publ., 259 p. (In Russ.).

Dovbij I.P. (2018). Russian Industry: Investment and Innovation Development and Economic Security: monograph. Chelyabinsk: SUSU Publ., 240 p. (In Russ.).

Drozdov O.A. (2014). To the Question of the Guidelines for New Industrialization in Russia. In: New Industrialization of Russia. Theoretical and Managerial Aspects. Ed. by N.F. Gazizullin. St. Petersburg: NPK "ROST" Publ. (In Russ.).

Glazyev S.Yu., Kharitonov V.V., eds. (2009). Nanotechnologies as a Key Factor for a New Technological Way in Economy. Moscow: Trovant Publ., 304 (In Russ.).

Gubanov S.S. (2008). Neo-Industrialization Plus Vertical Integration (On the Formula of Russia's Development). Ekonomist - The Economist, no. 9. pp. 3-27 (In Russ.).

Gubanov S. (2017). Neo-Industrialization: on the Question of the "Question" (Some Clarifications). Ekonomist The Economist, no. 3, pp. 43-53 (In Russ.).

Kabir L.S. (2017). Socially Responsible Investing: a Trend or a Temporary Phenomenon? Ekonomika. Nalogi. Pravo - Economics. Taxes. Law, no. 4, pp. 35-41 (In Russ.).

Kuznetsov B.V. Simachev Yu.V. (2014). Evolution of State Industrial Policy in Russia. Zhournal novoi ekonomicheskoi associacii - Journal of the New Economic Association, no. 2 (22), pp. 152-178 (In Russ.).

Kul'kov V.M. (2015). New Industrialization in the Context of Economic Development of Russia. Ekonomika. Nalogi. Pravo - Economics. Taxes. Law, no. 2. pp. 81-85 (In Russ.).

Kul'kov V.M. (2014). Post-Industrialization or New Industrialization? Problemy sovremennoy ekonomiki Problems of Modern Economy, no. 3, pp. 56-59 (In Russ.).

Lenchuk E.B. (2017). Formation of Human Resources for the Innovative Economy. Ekonomicheskoye vozrozhdeniye Rossii - Economic revival of Russia, no. 1 (51), pp. 22-26 (In Russ.).

Lenchuk E.B., ed. (2014). The Role of New Industrialization in Formation of Innovative Economy in Russia. In: Institutional Environment of the New Industrialization in the Russian economy: A collection. Moscow: IE RAS Publ., 264 (In Russ.).

Manturov D.V. (2018). On the Industrial Policy of Russia for 2018-2030. Vestnik MGIMO-Universiteta MGIMO Review of International Relations, no. 4 (61), pp. 7-22 (In Russ.). Available at: https://doi.org/10.24833/ 2071-8160-2018-4-61-7-22.

Pazdnikova N.P., Glazkova N.G., Buresh D.S. (2020). COVID-19: Influence of a New Type of Coronavirus Infection on the Country's National Economy. Ekonomika: vchera, segodnya, zavtra - Economics: Yesterday, Today and Tomorrow, vol. 10, iss. 2A, pp. 169-177 (In Russ.). Available at: https://doi.org/10.34670/AR.2020.21.54.015.

Ryazanov V.T. (2016). (Not) Real Capitalism. Political Economy of the Crisis and Its Consequences for the World Economy and Russia. Moscow: Ekonomika Publ., 695 p. (In Russ.).

Silin Ya.P., Animitsa, E.G., Novikova N.V. (2017). Regional Aspects of New Industrialization. Ekonomika regiona Economy of Region, vol. 13, iss. 3, pp. 684-696 (In Russ.). Available at: https://doi.org/1010.17059/2017-3-4.

Simachev Yu. (2014). Industrial Policy in Russia: Institutional Features, Interest Groups, Lessons for the Future. Nodes of Economic Policy Dispute Club of the Association of Independent Centers for Economic Analysis (In Russ.). Available at: https://www.econ.msu.ru/ext/lib/News/x20/x6e/8302/file/Simachev\%20presentation\%202014-01.pdf.

Stiglitz J.E. (2002). Globalization and Its Discontents. NY: W.W. Norton, 282 p.

Sukharev O.S. (2013). Reindustrialization in Russia. Opportunities and Restrictions. Ekonomist - The Economist, no. 3, pp. 6-12 (In Russ.).

Tatarkin A.l., Romanova O.A. (2014). Industrial Policy: Genesis, Regional Features and Legislative Provision. Ekonomika regiona - Economy of Region, no. 2, (38), pp. 9-21 (In Russ.). Available at: https://doi.org/10.17059/ 2014-2-1.

Tolkachev S.A. (2014). Reindustrialization in the USA: the Eve of the Neo-Industrial Order. Ekonomist - The Economist, no. 10, pp. 54-69 (In Russ.).

Tolkachev S.A., ed. (2018). The Industrial Policy of the Age of Digital Transformation in Economy. Moscow: KnoRus Publ., 204 p. (In Russ.).

United Nations (2015). Transforming our world: the 2030 Agenda for Sustainable Development (resolution A/ RES/70/1).

Received 11.07.2020

Accepted for publication 19.08.2020 


\title{
Выбор источников традиционного и "зеленого" финансирования наилучших Аоступных технологий
}

\author{
Ирина Игоревна Просвирина, А. э. Н., Аоцент, заведующий кафеАрой \\ бухгалтерского учета, анализа и аудита Южно-Уральского государствен- \\ ного университета (национального исследовательского университета), \\ г. Челябинск \\ E-mail: irina.prosvirina@susu.ru, ORCID 0000-0003-1791-993X \\ Наталья Сергеевна Аовбий, аспирант кафедры бухгалтерского учета, \\ анализа и аудита Южно-Уральского государственного университета \\ (национального исследовательского университета), г. Челябинск \\ E-mail: natasha_m92@mail.ru
}

\begin{abstract}
Аннотация
Россия постепенно расширяет принципы "зеленого" развития национальной экономики. В статье исследуется состояние метолологического и институционального обеспечения "зеленых" инвестиций, анализируются проблемы, сдерживающие финансирование наилучших доступных техно^огий. Установлена ведущая роль государства в устранении институциональных разрывов между индивиАуальными интересами инвесторов и комективными проблемами общества. Авторами исследованы различные критерии выбора источников финансирования, слелан вывод о целесообразности развития в России отношений "зеленого" кредитования с учетом нормативных ограничений и ESG-рисков. В теоретическом (методическом) аспекте авторы выделили специфические черты "зеленого" финансирования как триединства элементов: “объект-субъект-институциональная среда"; каждый из признаков должен отвечать принципам "зеленого" финансирования. Обоснована необходимость Аальнейшего формирования институциональной среды "зеленого" финансирования. В практическом плане Аля субъектов из списка 300 предприятий-загрязнителей, перед которыми стоит задача обновления основного капитала на основе наилучших доступных технологий, было проведено моделирование на основе имеющихся статистических данных, позвомившее получить ответы на вопросы: какие факторы влияют на прирост внеоборотных активов, в том числе факторы, связанные с источниками их финансирования. Определено, что в первую очередь предприятия решают проблему текущего управления и Аостаточности оборотных среАств и лишь затем начинают направлять финансовые ресурсы на обновление основного капитала. На основе полученных результатов сформулированы основные проблемы и показаны основные задачи "зеленого" развития российской экономики. При написании статьи применялись современные методы системного и статистического анализа, экономико-математического моделирования.
\end{abstract}

Ключевые слова: наилучшие Аоступные технологии, финансирование, источники "зеленого" финансирования, "зеленые" инвестиции, устойчивое развитие

JEL: D02, 014, 044

Аля цитирования: Просвирина И. И., Аовбий Н. С. Выбор источников традиционного и "зеленого" финансирования наилучших доступных технологий // Финансовый журнал. 2020. T. 12 . № 4. C. 101-116. DOI: 10.31107/2075-1990-2020-4-101-116. 
DOI: 10.31107/2075-1990-2020-4-101-116

\title{
Selection of Sources of Traditional and Green Financing for the Best Available Techniques
}

\author{
Irina I. Prosvirina ${ }^{1}$ \\ E-mail: irina.prosvirina@susu.ru \\ Natalya S. Dovbiy ${ }^{1}$ \\ E-mail: natasha_m92@mail.ru \\ ${ }^{1}$ South Ural State University, Chelyabinsk 454080, Russian Federation
}

\begin{abstract}
Russia has been gradually expanding the principles of green development in the national economy. The article examines the state of methodological and institutional support for green investments, and analyzes the problems that hinder the financing of the best available techniques. The leading role of the state in eliminating institutional gaps between the individual interests of investors and the collective problems of society is established. The authors have investigated various criteria for selecting sources of financing and concluded that it is appropriate to develop green lending relationships in Russia, taking into account regulatory restrictions and ESG risks. In the theoretical (methodological) aspect, the authors have identified specific features of green financing as a trinity of elements: "ObjectSubject-Institutional Environment"; each of the features must meet the principles of green financing. The necessity of further formation of the institutional environment for green financing is justified. In practical terms, statistical data-based modeling has been carried out for entities from a list of 300 polluting enterprises that need to update their fixed assets based on the best available techniques. This study has provided answers to the questions of what factors influence the growth of non-current assets, including factors related to the sources of their financing. It is determined that first of all enterprises solve the problem of current management and working capital adequacy, and only then begin to direct financial resources to updating the fixed capital. Based on the results obtained, the main problems are formed and the main tasks of the nearest development of green development principles in the Russian economy are shown. When writing the article, the authors used modern methods of systemic and statistical analysis as well as economic and mathematical modeling.
\end{abstract}

Keywords: best available techniques (BAT), financing the "new industrialization", sources of green finance, green investments, sustainable development

JEL: D02, 014, 044

For citation: Prosvirina I.I., Dovbiy N.S. Selection of Sources of Traditional and Green Financing for the Best Available Techniques. Financial Journal, 2020, vol. 12, no. 4, pp. 101-116 (In Russ.). DOI: 10.31107/2075-1990-2020-4-101-116. 


\section{ВВЕАЕНИЕ}

В XXI в. Российская Федерация активно участвует в международном климатическом процессе, постепенно внеАряя принципы "зеленого" развития в национальную экономику. Так, благодаря решению России о ратификации Киотского протокола в 2005 г. он вступил в силу. В 2009 г. Распоряжением Президента РФ от 17.12.2009 № 861-рп была принята "Климатическая Аоктрина Российской Федерации" ; в 2019 г. - Постановление Правительства РФ от 21.09.2019 № 1228 "О принятии Парижского соглашения 2015 года»"; Распоряжением Правительства РФ от 25.12.2019 № 3183-р определен национальный план адаптации к изменениям кмимата Ао 2022 года ${ }^{3}$. ОАнако в таком важнейшем Аокументе, как национальный проект "Экология", вопросы, связанные с изменением климата, остались неохваченными. По данным Счетной палаты РФ, на начало четвертого квартала 2019 г. кассовое исполнение мероприятий нацпроекта “Экология" составило мишь 27,1 \% от установленных сводной бюАжетной росписью ассигнований ${ }^{4}$. Развитие национального хозяйства сопряжено с ростом негативного воздействия на окружающую среду и накоплением негативных экологических эффектов, влияющих на климатические изменения, в связи с чем становится безальтернативным путь "озеленения" экономики. Таким образом, перед предприятиями, оказывающими наиболее негативное влияние на экологию (это компании следующих отраслей: топливно-энергетический комплекс, химия и нефтехимия, метаммургия, системы водоотведения, производство цемента, стекла и проч.), встает проблема модернизации основного капитала на принципах наилучших Аоступных технологий (Аалее также - НАТ).

По оценкам Минпромторга России, Аля перехода на НАТ требуется порядка 8,2 трлн руб. инвестиций. Общая же оценка затрат на модернизацию морально и физически изношенного оборудования Ао современного технологического уровня определена в объеме 13,6 трлн руб. ${ }^{5}$ Возникает ряд вопросов: кто профинансирует модернизацию? за счет каких источников? каковы наиболее приемлемые инструменты? на каких условиях возможно "зеленое" финансирование?

Формирующийся российский финансовый рынок, регулируемый Банком России, последовательно и постепенно адаптируется к зарубежным подходам к его регулированию, принципам ведения отчетности в соответствии с МСФО, новым инструментам "зеленого" финансирования и к государственной поддержке “зеленых" инвесторов. Таким образом, задача выработки методологии "зеленого" финансирования и определения его источников приобретает острую актуальность. В связи с этим целью настоящего исследования является попытка сформулировать некоторые общие методологические подходы к начавшемуся процессу "зеленого" финансирования в России, а также выделить ряд практических задач, решение которых будет способствовать не только его лучшему регулированию и внеАрению, но и повышению возможности исследователей (экономистов, экологов и Аругих заинтересованных профессиональных сообществ) Аля быстрой и качественной оценки результатов Аанной большой работы.

\section{ОСНОВЫ ИНСТИТУЦИОНААЬНОГО ОФОРМАЕНИЯ “ЗЕАЕНОГО" ФИНАНСИРОВАНИЯ}

Рубеж XX-XXI вв. ознаменовался трансформацией структуры и принципов финансирования, что было обусловлено выходом на рынок новых виАов инвестиций, характеризующих

\footnotetext{
1 Распоряжение Президента РФ от 17.12.2009 № 861-рп “О Климатической доктрине Российской Федерации”.

2 Постановление Правительства РФ от 21.09.2019 № 1228 “О принятии Парижского соглашения".

з Распоряжение Правительства РФ от 25.12.2019 № 3183-р “Об утвержАении национального плана мероприятий первого этапа адаптации к изменениям климата на период АО 2022 года".

4 http://old.ach.gov.ru/activities/control/Экология\%202020-01-15\%20[1].pdf.

${ }^{5}$ https://www.mnr.gov.ru/docs/latonova.pdf.
} 
целевую направленность проекта. На стыке Авух сфер человеческой Аеятельности финансовой и экологической - формируется новая экосистема глобальных финансов система ответственного финансирования (ESG-finance), в том числе система "зеленого" финансирования, в основе которой лежат три фактора рисков - экологический, социальный и управленческий (ESG - Environmental, Social, Governance). Экосистема «зеленого" финансирования создана Аля Аостижения 17 целей устойчивого развития, изложенных в повестке Аня ООН в области устойчивого развития на периоА Ао 2030 г. В рамках нового подхода государства - члены ООН обязуются не только начать реализацию мероприятий по экологизации экономики, но и осуществлять поААержку новых метоАов финансирования и в целом "озеленения" финансовой системы [Кабир ^. С., 2017]. Интересно также отметить, что финансы названы в числе отраслей, создающих благоприятные условия Аля перехода к "зеленой" экономике [Кабир ^. С., 2019].

Аанные факторы должны учитываться, с одной стороны, компаниями и организациями всех форм собственности, привлекающими инвестиции Аля своего развития, с Аругой стороны, - институциональными инвесторами и финансирующими организациями в кредитных политиках и инвестиционных стратегиях. Наряду с традиционными финансовыми инструментами на финансовый рынок вышли инструменты ответственного финансирования проектов. Это обусловлено глобальным развитием процесса социально ответственного инвестирования, при котором требования инвесторов связываются не только с определенной нормой дохода, но и с соответствием объекта инвестиций экологическим, социальным и этическим критериям. Естественным процессом стало выделение ведущими странами мира "зеленого" финансирования в качестве важнейшего инструмента решения задач, связанных с обеспечением устойчивого к изменению климата социальноэкономического развития.

Наблюдаемый на мировых рынках бум “зеленых" финансовых инструментов, используемых Аля привлечения среАств на проекты, способствующие развитию низкоуглероАной экономики, произвоАству возобновляемой энергии, повышению энергоэффективности и прочих "зеленых" технологий, подводит Россию к постепенному включению в глобальную экосистему в области “зеленого" финансирования. Об этом свидетельствуют принятые в последние годы национальные проекты, совпадающие с Целями устойчивого развития ООН по Аостижению социо-эколого-экономических эффектов. Сформированы ESG-рейтинг России и регионов, а также рейтинг экологической эффективности крупнейших компаний страны.

По состоянию на середину февраля 2020 г. пять российских эмитентов получили поАтвержАение от внешних верификаторов о соответствии выпусков принципам "зеленых" облигаций ICMА и провели размещение семи выпусков таких облигаций общим объемом 7,55 млра руб. и 500 млн евро, в том числе:

- в Аекабре 2018 г. на Московской бирже были размещены корпоративные проектные (концессионные) облигации ООО “Ресурсосбережение ХМАО" на 1,1 млрА руб. Аля финансирования проектов переработки и утилизации твердых коммунальных ОтХОАОВ;

- в мае 2019 г. на ИрланАской бирже - еврооблигации ОАО "РЖА" на 500 млн евро Аля развития железнодорожной транспортной инфраструктуры;

- в ноябре 2019 г. на Московской бирже - корпоративные облигации ПАО КБ «ЦентрИнвест" на 250 млн руб. на создание возобновляемых источников энергии и экологичного транспорта Краснодарского края;

- в Аекабре 2019 г. на Московской бирже - корпоративные облигации АО «Коммерческая неАвижимость ФПК "Гарант-Инвест" на 500 млн руб. Аля развития зеленых техномогий и финансирования коммерческой недвижимости;

- в феврале 2020 г. на Московской бирже тремя выпусками по 4,7 млрА, 900 млн и 100 млн руб. были размещены структурные облигации ООО "СФО РуСол 1" Аля 
финансирования проектов зеленой энергетики, солнечных электростанций Астраханской области.

А^я трех эмитентов подтвержАение было выдано рейтинговым агентством RAEXEurope, а три выпуска включены в реестры и международные базы данных "зеленых" облигацийб. В числе инвесторов, разместивших свои ресурсы в отечественные "зеленые" инструменты, есть и негосударственные пенсионные фонды.

Аля запуска механизмов финансирования "зеленых" инвестиций необходимо, чтобы идеи, подходы и инструменты, присущие "зеленой" экономике, были качественно аАаптированы применительно к российским условиям и имели единую интерпретацию в различных документах стратегического характера.

Ряд ученых отмечает, что в России уже «набирают темпы процессы законодательного регулирования деятельности компаний в природоохранной и ресурсосберегающей сферах, выстраивания национальных систем внедрения в производство новых "зеленых" технологий, формирования "зеленых" отраслей экономики, поиска и апробации новых инструментов финансирования перехода к "зеленой" экономике, стандартизации и формализации требований по раскрытию компаниями информации в этой сфере и Ар." [Яковлев И. А. и Ар., 2017]. Формирование институциональной среды "зеленых" инвестиций Аолжно проходить с учетом всех заинтересованных сторон в процессе "озеленения" национальной экономики сторон.

Спецификой "зеленых" инвестиций, как показывает опыт развитых стран, является то, что принципиальным заказчиком, гарантом и соинвестором выступает госуАарство, которое устраняет разрыв между индивидуальными интересами инвесторов и коммективными проблемами общества.

Поскольку главным интересом общества является совокупность реальных мичных интересов, которые объективно предполагают прогресс и социально-экономическую гармонизацию, постольку экономические интересы Аолжны учитывать совокупность специфических свойств экономических субъектов, включая собственников, инвесторов, кредиторов, производителей, покупателей, продавцов и т. А. Мы разделяем мнение о том [Аовбий И. П., 2018], что экономические интересы проявляются в Аиалектическом еАинстве человека и системы общественного производства. Они включают в себя множество индивидуальных, общественных, государственных, национальных, групповых и прочих интересов. В условиях переориентации глобального хозяйства на “зеленую" экономику государственные интересы обеспечения устойчивого развития общества и государственное регулирование становятся объективно необходимыми, принимают форму государственных экстерналий, поскольку институты рынка "зеленого" финансирования (формальные и неформальные, комлективные и индивидуальные) могут включать элементы различных "юрисаикций" регулирования, представлять интересы различных целевых аудиторий. Наличие многообразия финансов, обеспечивающих устойчивое развитие, уже отмечено в экономических изданиях (см., в частности [Яковлев И. А. и Ар., 2018].

Так, например, основными провайдерами "Алинных Аенег" в российской экономике являются банки, принимающие на свои балансы повышенные процентные риски и пытающиеся хеджировать их, увеличивая стоимость кредитования. В связи с внедрением нового Базельского стандарта по управлению процентными рисками необходима гармонизация интересов кредитных организаций по способам их перераспределения, с оАной стороны, и инициаторов "зеленых" проектов, с Аругой. Аанное становится возможным только при синхронизации и совместном участии государственных органов (Минфина, Минэкономразвития, Банка России), участников рынка, инфраструктурных учреждений, экспертных и консультативных советов и проч. (рис. 1).

\footnotetext{
${ }^{6}$ https://energiavita.ru/wp-content/uploads/2020/02/NAKDI-green-finance-2020.pdf.
} 


\section{Институты рынка "зеленого" финансирования / Institutions of green finance market}

\begin{tabular}{|c|c|c|}
\hline & $\begin{array}{l}\text { ГосуААРство: } \\
\text { промышленная, } \\
\text { экологическая, }\end{array}$ & \\
\hline \multirow[b]{2}{*}{$\begin{array}{l}\text { Формальные институты: } \\
\text { законодательные и нормативные акты; } \\
\text { политика государства (промышленная, } \\
\text { экологическая, финансовая); } \\
\text { официальные Аокументы; финансовые } \\
\text { инструменты (кредиты, займы, ценные } \\
\text { бумаги и индексы, квоты на загряз- } \\
\text { нение); регулирующие стимулы Аля } \\
\text { деятельности агентов реального } \\
\text { и финансового секторов, обеспечива- } \\
\text { ющие условия Аля формирования } \\
\text { "зеленых" инвестиций }\end{array}$} & & \multirow[b]{2}{*}{\begin{tabular}{l}
\multicolumn{1}{l}{ Неформальные институты: } \\
- нормативные (система нормативов, \\
требований, стандартов, маркеров, \\
отчетности “зеленых" продуктов; \\
рейтинги, мониторинг, инструменты \\
оценки рисков и эффективности; \\
центры сбора, структурирования \\
и накопления информации; \\
мероприятия "зеленой" тематики \\
- когнитивные - компетенции и \\
особенности взаимодействия агентов
\end{tabular}} \\
\hline & & \\
\hline \multicolumn{3}{|c|}{ Субъекты системы "зеленого" финансирования: } \\
\hline \multicolumn{3}{|c|}{$\begin{array}{l}\text { - органы регулирования в финансово-кредитной сфере, экономического развития } \\
\text { и охраны окружающей среды; } \\
\text { - банки, страховые и лизинговые компании, фонды (национальные, специализированные); } \\
\text { - участники финансового рынка: финансовые компании, организаторы выпусков, эмитенты, } \\
\text { получатели и потребители финансовых продуктов, финансирующие организации, заемщики, инвесторы, } \\
\text { управляющие активами и др.; } \\
\text { - инфраструктурные и сервисные организации: организаторы торгов, биржи, рейтинговые агентства, } \\
\text { сертифицирующие, верификаторы и др.; } \\
\text { - профессиональные аналитические, экспертные и исследовательские организации; } \\
\text { - проектные компании, юридические и технические консультанты; ценовые центры }\end{array}$} \\
\hline
\end{tabular}

Источник: составлено авторами / Source: compiled by the authors.

При формировании институциональной среды "зеленого" финансирования роль государства состоит в стимулировании и поддержке "зеленых" инвестиций в технико-технологические инновации, выступающие базисом промышленности, а также в формировании условий Аля эффективного взаимодействия многоуровневой системы формальных и неформальных институтов и финансово-кредитной составляющей. В целях содействия Аолгосрочным "зеленым" инвестициям особое внимание государства Аолжно быть направлено на инструменты (Аолгосрочные кредиты, концессионные облигации и Ар.), защиту инвесторов, институты развития, инфраструктуру, рейтинги, механизмы раскрытия информации в интересах инвесторов и т. А.

Вместе с тем следует указать на наличие проблемы (как в России, так и за рубежом), обусловленной отсутствием согласованной позиции в отношении таких понятий, как "зеленая" экономика, "зеленые" инвестиции, "зеленые" финансы, "зеленые" проекты. Финансовая стабильность системы "зеленого" инвестирования должна быть подкреплена формальными и неформальными институтами. В Концепции организации в России методологической системы по развитию зеленых финансовых инструментов и проектов ответственного инвестирования отмечается, что потребность в институциализации и гармонизации экосистемы "зеленых" инвестиций актуализирует задачу разработки их методологического сопровожАения, поскольку необходимо выработать еАиные подходы, критерии и правила развития, а также инструменты оценки эффективности, подАержки и стимулирования?.

\footnotetext{
7 https://cbr.ru/Content/Document/File/84163/press_04102019.pdf.
} 
Разработкой методологии "зеленых" финансов в России занимается прежде всего Банк России как мегарегулятор отечественного финансового рынка, в частности Рабочая группа по вопросам ответственного финансирования (ESG-finance), в том числе "зеленого", и Экспертный совет по рынку Аолгосрочных инвестиций. Активными участниками этого процесса выступают Национальная ассоциация концессионеров и Аолгосрочных инвесторов в инфраструктуру, являющаяся сетевым партнером Ассоциации ответственного инвестирования PRI, саморегулируемая организация «Национальная финансовая ассоциация", Ассоциация региональных банков России, Центр компетенций и зеленой экспертизы (экспертная платформа в области устойчивого развития и “зеленых" финансов), финансовые компании, рейтинговые агентства, проектные компании, юридические и технические консультанты, организаторы выпусков.

Таким образом, несмотря на некоторую фрагментарность, можно говорить о начале формирования в России институциональной среды "зеленого" финансирования. На Аанном этапе необходимо прежАе всего обеспечить институциональное оформление отношений "зеленого" инвестирования в части формирования четких правил и понятийной базы.

\section{ИНСТРУМЕНТЫ “ЗЕАЕНОГО" ФИНАНСИРОВАНИЯ НАИАУЧШИХ АОСТУПНЫХ ТЕХНОЛОГИй}

Источники и инструменты финансирования инвестиций классифицируются по различным критериям, но прежде всего рассматриваются собственные, заемные и привлеченные средства.

Традиционными критериями выбора источников финансирования яв^яются: соответствие спроса и преАложения финансовых ресурсов по конкретному проекту, соответствие предложения временным рамкам проекта, цена привлечения, систематические и несистематические риски, эффективность воспроизводства собственных среАств, оценка соответствия источников финансирования структуре инвестиций в проект и т. А.

В качестве отдельных критериев выбора межАу традиционным и “зеленым" финансированием следует указать институциональную и инфраструктурную обеспеченность, намичие государственной подАержки в виде государственных программ, проектов, инструментов стимулирования, степень развития финансово-кредитного рынка. ЗАесь следует отметить, что российская финансовая система традиционно относится к банковской модели финансирования с традиционными предпочтениями кредитов в качестве источников финансирования инвестиций экономическими субъектами, с оАной стороны; с Аругой - депозитов в качестве средства сбережений населения.

В России «зеленое" кредитование только начинает выделяться в качестве самостоятельного термина. ОАнако оно является совершенно новой формой кредитных отношений, отражающих Аиалектику развития, основанного на принципах экологичности. Выявление специфических особенностей "зеленого" кредита предполагает изучение комплекса элементов, определяющих его сущностное содержание: предмета и объекта кредитования, субъектов кредитных отношений, форм и методов Авижения ссудной стоимости от креАитора к заемщику, способов обеспечения возврата, принципов кредитования, требований к управлению кредитованием и т. А.

Факторы экологических, социальных и управленческих рисков (ESG) могут оказывать существенное влияние на кредитный рейтинг на количественном и качественном уровне, определяя качество кредитного портфеля. Например, в методологии корпоративных рейтингов S\&P Global Ratings имеется свыше ста отсы^ок к факторам ESG. В частности, в числе критериев по оценке менеджмента и корпоративного управления особое внимание уделяется качеству менеАжмента, адекватности выбранной компанией стратегии, быстроизменяющимся условиям и возникающим рискам, Аостаточности раскрытия 
информации и др. Аля большинства компаний таких отраслей, как нефтяная, газовая и энергетическая, на формирование рейтингов существенное влияние оказывают экологические и кииматические (Е\&C) риски ${ }^{8}$.

Обозначим несколько отличительных признаков "традиционного", "инвестиционного" и "зеленого" кредита.

Аля традиционного кредитования характерно ссужение заемщику денежных ресурсов в виде "кредитования под объект". Главным условием Аля инвестора (банка) является своевременный возврат выданной ссуды с процентами. Это преАполагает прибыльную деятельность заемщика. В Аанной системе отношений самое важное - это экономический эффект (норма прибыли).

Инвестиционное кредитование (проектное финансирование) представляет собой более сложный механизм, предполагающий средне- и Аолгосрочное "кредитование субъекта под объект", при этом к субъекту предъявляются специфические требования в части его платеже- и кредитоспособности, качества менеджмента по управлению проектом, наличия деловых связей, налоговой благонадежности и проч. Главное условие Аля инвестора (синдиката инвесторов) - Аостижение целей инвестиционного проекта, запуск механизма формирования новых каналов генерирования Аенежных потоков. В качестве базовых условий финансирования, как правило, выбираются прибыль и рост стоимости бизнеса. В отдельных случаях наряду с экономическим Аостигаются социальные эффекты.

"Зеленое" кредитование подчинено совершенно новой могике - логике формирования "зеленой" экономики и кредитования тех видов хозяйственной деятельности, Аля которых модернизация и повышение эффективности производства являются способом Аостижения не только экономического и социального, но и экологического эффекта.

"Зеленое" финансирование имеет не просто ярко выраженный "субъект-объектный" характер, Аостижение результата возможно только при наличии соответствующей среды. В аналитической записке "Меры государственной подАержки в странах "группы АваАцати"..." Аелается акцент на то, что "зеленое" финансирование - это всегАа финансирование инноваций, "направленных на улучшение среды проживания ^юАей, снижение техногенных выбросов, аАаптацию хозяйственного комплекса и населения стран к изменяющимся климатическим условиям" 9 .

На основе анализа официальных Аокументов ${ }^{10}$ и научных работ, посвященных вопросам развития теории и практики финансирования [Аовбий И. П., 2011], преАлагаем выдемить следующие методологически важные и принципиальные характеристики "зеленого" кредитования, которые в полной мере можно отнести ко всем инструментам и направлениям "зеленого" финансирования:

- наличие специфического объекта кредитования, Аокументально оформленного в виде "зеленого" проекта, то есть прошедшего "зеленую" сертификацию; соответствующего критериям отнесения проектов к категории "зеленых»; отражающего объективные потребности устойчивого развития (сохранность окружающей среды, формирование инфраструктуры, обеспечивающей снижение негативных воздействий на экологию и изменение климата и т. п.);

- субъект кредитования должен, во-первых, Аокументально оформить "зеленую" помитику и порядок ответственных действий на рынке; во-вторых, Аолжен заявить объект кредитования в качестве "зеленого" проекта, нацеленного на создание "зеленых" техномогий; в-третьих, поАтверАить креАитоспособность и устойчивость бизнеса, в том числе

\footnotetext{
8 https://investinfra.ru/frontend/images/PDF/Михаил\%20давыдов.pdf.

9 https://investinfra.ru/frontend/images/PDF/minfin-green-docs/minfin-green-docs-09.pdf.

${ }^{10}$ https://cbr.ru/Content/Document/File/84163/press_04102019.pdf.
} 
с учетом ESG-факторов (требуемые Аля "зеленого" финансирования кредитное качество или рейтинг кредитоспособности); в-четвертых, обеспечить эффективный менеАжмент проекта, формируя денежные потоки от реализации проекта и обеспечивая полный возврат средств кредитору; в-пятых, раскрывать публичную нефинансовую отчетность по комплексу экономических и ESG-показателей;

- специфическая институциональная среда кредитования, во-первых, формируется на базе консолидированной позиции государства, выступающего организатором процесса; предполагает бюАжетный подход к реализации “зеленого" проекта, несмотря на то что основана на рыночных принципах и осуществляется на основе государственночастного партнерства; во-вторых, базируется на методологии и институтах оценки рисков ESG-инвестирования с акцентом на учет изменения климата; в-третьих, обеспечивает верификацию "зеленых" финансовых инструментов на предмет соответствия "зеленым" критериям; в-четвертых, осуществляет ведение реестра реализуемых "зеленых" проектов и финансирующих их организаций; в-пятых, проводит консультации по инструментам государственной подАержки, разрабатывает рекомендации инвесторам и т. А.

Среди проблем методологического и методического оформления отношений, возникающих в процессе финансирования "зеленых" инвестиций, в качестве важнейшей отметим следующую. Термин «зеленые» пока принято относить лишь к пяти направлениям экономической деятельности: возобновляемым источникам энергии, энергоэффективности, системам жизнеобеспечения, “зеленым" корпоративным НИОКР и "зеленому" строительству ("умные" города, "умные" зАания и проч.). На наш взгляА, необходимо расширить этот перечень, а также выработать критерии и показатели четкого отнесения финансируемых проектов к категории "зеленые».

Таким образом, в настоящее время в России наблюдается процесс становления методологии «зеленого" финансирования. Основные задачи этого этапа связаны с формированием четкой и понятной методологии, позволяющей отАелить новый инструмент финансирования от традиционных кредитов и облигационных займов, необходимостью учесть положительный опыт Аругих стран, созданием полного комплекса регулирующих актов, в том числе содержащих условия мотивации и льготирования участников "зеленой" модернизации.

\section{"ЗЕАЕНАЯ" ЭКОНОМИКА И ПРОБАЕМЫ ФИНАНСИРОВАНИЯ НАИАУЧШИХ АОСТУПНЫХ ТЕХНОАОГИЙ}

В России, как и других странах, переход к "зеленой" экономике осуществляется за счет снижения энергопотребления и повсеместного применения более экологичных решений в технике и технологиях. В числе тенденций, которые Аолжен закрепить переход к "зеленой" экономике, следует назвать, с оАной стороны, увеличение государственных инвестиций и расходов в «зеленые» проекты; с Аругой - отказ от государственного субсидирования экологически вредных производств. Экономическая конкуренция на всех уровнях (от глобального до микроуровня) все больше перемещается в зону "зеленых" технологий: потенциал государства будет определяться скоростью и масштабами их внедрения, а не только способностью к научно-техническому прогрессу.

Впервые страны Европейского союза закрепили требования комплексного контро^я и предотвращения загрязнений в Аирективе Совета Европы 96/61, институционально оформив этот процесс на основе понятия "наилучшие Аоступные технологии" (Best Available Techniques, BAT $)^{11}$.

${ }^{11}$ Council Directive 96/61/EC of 24 September 1996 concerning integrated pollution prevention and control. URL: https://eur-lex.europa.eu/eli/dir/1996/61/oj. 
В России лишь в 2015 г. вступил в Аействие Федеральный закон № 219-Ф3, в котором Аля предприятий, оказывающих негативное воздействие на окружающую среду, предусмотрено обязательное внедрение наилучших доступных технологий (НАТ) - одного из механизмов перевода национальной промышленности на рельсы “зеленой" экономики. В редакции закона «наилучшая доступная технология - технология производства продукции (товаров), выполнения работ, оказания услуг, определяемая на основе современных достижений науки и техники и наилучшего сочетания критериев достижения целей охраны окружающей среды при условии наличия технической возможности ее применения ${ }^{12}$.

В узком смысле НАТ направлены на охрану окружающей среАы и ужесточение нормирования выбросов и сбросов загрязняющих веществ, в широком - на ускоренный технологический рост во всех отраслях, модернизацию существующих производств, а также строительство новых, отвечающих мировым требованиям. НАТ, рассматриваемые в контексте экономического и экологического регулирования, Аолжны прийти на смену устаревшему оборудованию, обеспечивая ресурсосбережение, безотходные производства, модернизированные технологии и т. А.

В Российской ФеАерации задача обеспечить комплексный поАХоА К внеАрению НАТ содержится в Аокументах экологической и промышленной политики и требует постоянного совершенствования системы государственного регулирования на принципах НАТ. В развитии этой системы значительную роль играют Росстандарт и механизмы стандартизации.

В РФ уже существует перечень 300 предприятий (предприятий-загрязнителей), оказывающих негативное воздействие на окружающую среду и относящихся к I категории, вклаА которых в суммарные выбросы и сбросы загрязняющих веществ составляет не менее $60 \%{ }^{13}$. В соответствии с п. 1 ст. 23 Федерального закона № 7-Ф3 «Об охране окружающей среды" Аанные предприятия относятся к областям применения НАТ.

В перечень НАТ, разрабатываемых Аля предприятий различных отраслей, включаются основанные на современных достижениях научно-технического прогресса производственные процессы, оборудование, технические методы, способы, приемы и средства, характеризующиеся комплексом критериев: наименьший уровень негативного возАействия на окружающую среду в расчете на единицу времени или объем производимой продукции (товара); экономическая эффективность внеАрения и эксплуатации; применение ресурсо- и энергосберегающих методов; период внедрения; промышленное внедрение на двух и более объектах, оказывающих негативное воздействие на окружающую среду ${ }^{14}$. НАТ выступают в качестве связующего звена промышленной и экологической компонент государственной политики.

Входящие в перечень юридические лица обязаны в течение четырех лет, начиная с января 2019 г., получить в Росприроднадзоре Комплексное экологическое разрешение (КЭР), на основе которого Аолжна начаться модернизация производства на принципах "зеленых" технологий. Государственное регулирование на основе НАТ содействует развитию бизнеса, повышению его конкурентоспособности при оАновременном снижении негативных экологических эффектов.

Обновление основных фондов с учетом новых экологических стандартов сопряжено с увеличением стоимости разработки новых технологий, отвечающих принципам "зеленой" экономики. Общество в целом и промышленные предприятия в частности неизбежно

\footnotetext{
12 Федеральный закон Российской Федерации № 219-ФЗ от 21 июля 2014 г. "О внесении изменений в Федеральный закон “Об охране окружающей среды и отдельные законодательные акты Российской ФеАерации)”".

13 Приказ Минприроды России от 18.04.2018 № 154 “Об утверждении перечня объектов, оказывающих негативное воздействие на окружающую среду, относящихся к I категории, вклад которых в суммарные выбросы, сбросы загрязняющих веществ в Российской Федерации составляет не менее чем 60 процентов".

${ }^{14}$ Федеральный закон № 7-ФЗ “Об охране окружающей среды” от 10.01.2002 (ст. 28.1, п. 4).
} 
столкнутся с проблемой поиска и выбора источников финансирования: традиционные или "зеленые".

В целях обеспечения государственной подАержки процесса внеАрения НАТ Правительством России в мае 2019 г. были утверждены «Правила предоставления субсидий из федерального бюджета российским организациям на возмещение затрат на выплату купонного дохода по облигациям, выпущенным в рамках реализации инвестиционных проектов по внеАрению наилучших Аоступных технологий ${ }^{15}$. Большинство компаний, входящих в список, провозгласили принцип социально ответственного ведения бизнеса.

Наилучшие Аоступные технологии - технологии, "которые созАают экологически безопасный способ получения продукции и формируют тип произвоАства, который опреАеляется как экологически чистое" [Карелов С. В. и Ар., 2012]. Исходя из критериев, сформулированных Аля определения НАТ в Федеральном законе № 7-Ф3 "Об охране окружающей среды" от 10.01.2002, можно утвержАать, что Аанные технологии являются совокупностью имущественных ценностей, включающих материальные, нематериальные и неосязаемые активы.

С точки зрения бухгалтерского подхода НАТ - это внеоборотные активы, характеризующиеся способностью приносить хозяйствующему субъекту экономические выгоды в течение Алительного времени. От таких параметров внеоборотных активов, как состояние (степень износа / годность), количество и качество (необходимое и достаточное), эффективность использования (ресурсоемкость, отдача и проч.), зависят финансовые результаты, стабильность экономической и эффективность произвоАственной Аеятельности промышленного преАприятия.

Внедрение НАТ поАнимает проблему качественного управления внеоборотными активами, выбора источников финансирования и выявления факторов, определяющих эффективность их использования. В частности, становится актуальной проблема финансового состояния компании, привлекающей "зеленое» финансирование. Ааже государственная подАержка не отменяет требований инвесторов к уровню платежеспособности эмитентов и заемщиков.

Традиционно источники финансирования внеоборотных активов подразделяются на собственные (средства учредителей, накопленная прибыль, амортизационные отчисления и т. А.) и заемные/привлеченные (банковские кредиты, займы, выпуск долговых ценных бумаг, мизинг и т. А.). Соотношение собственных и заемных средств при финансировании реальных инвестиций определяется финансовым рычагом, который на момент привлечения инвестиций сформировался исходя из рыночной стоимости финансовых ресурсов всех типов. Сложившаяся структура источников финансирования внеоборотных активов будет оказывать положительное или отрицательное влияние на финансовоэкономические показатели преАприятия, определяя возможности его “зеленого" развития.

\section{ОЦЕНКА ФАКТОРОВ, ВАИЯЮЩИХ НА ВЫБОР ИСТОЧНИКОВ ФИНАНСИРОВАНИЯ ОСНОВНОГО КАПИТААА}

В числе факторов, определяющих выбор источников финансирования основного капитала, следует особо выАелить возможность сохранения контроля наА бизнесом и финансовой независимости. Управление капиталом компании поднимает вопрос баланса между величиной собственного и заемного капитала. Величина и структура капитала существенно изменяются в течение жизненного цикла компании, расширяя возможности использования различных рыночных инструментов (см. рис. 2).

\footnotetext{
${ }^{15}$ Постановление Правительства РФ от 30.04.2019 № 541 «Об утвержАении Правил предоставления субсиАий из федерального бюАжета российским организациям на возмещение затрат на выплату купонного дохода по облигациям, выпущенным в рамках реализации инвестиционных проектов по внедрению наилучших Аоступных технологий”.
} 


\section{Формирование капитала компании во времени /} Formation of capital in a company over time

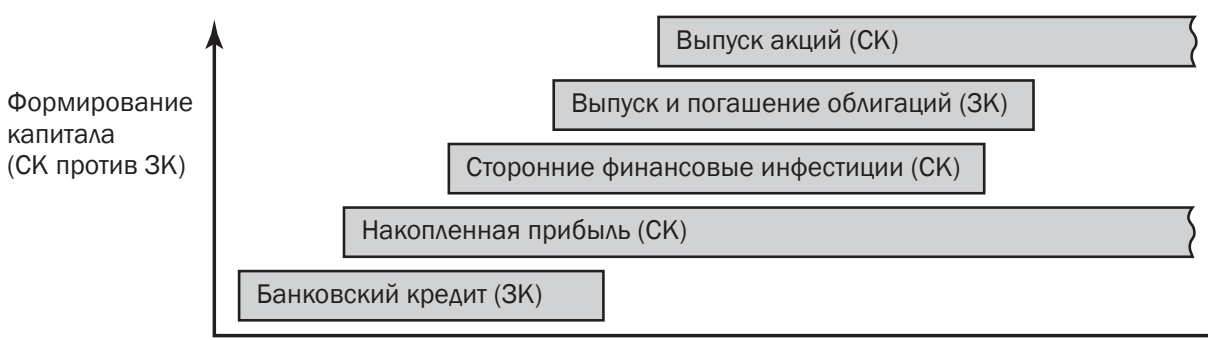

Источник: [Недосекин А. О., 2012, с. 7] / Source: [Nedosekin A. 0., 2012, p. 7].

Сказанное касается не только традиционных источников финансирования инвестиций, но и "зеленых" инвестиций, привлечение которых Аля развития бизнеса, как показано выше, сопряжено с выполнением целого ряда обязательных условий.

Поскольку внеАрение НАТ является обязательным Аля преАприятий из перечня 300, то преАставляет научный интерес анализ с позиций эффективности использования их внеоборотных активов и ее взаимосвязи с источниками финансирования. В настоящее время эффективность использования активов компаний, улучшающих экологическую ситуацию в стране и регионах (как экономическую, так и социальную), затруднительно опреАелить по Авум причинам. Во-первых, накоплено неАостаточно практики внеАрения НАТ, во-вторых, не создана система показателей государственной статистики Аля регулярных или разовых статистических наблюдений. В нашем исследовании сделана попытка на основе имеющихся статистических данных получить ответы на поставленные вопросы, а именно: какие факторы влияют на прирост внеоборотных активов, в том числе факторы, связанные с источниками их финансирования?

В целях исследования из списка 300 промышленных предприятий-загрязнителей, установленного Министерством природы РФ, исключены преАприятия, осуществляющие водоочистку, водоснабжение и водоотведение, занимающиеся нефте-, газо- и углеАобычей, а также гидротехнические и канализационные очистные сооружения. Кроме того, исключены преАприятия, у которых отсутствовали некоторые Аанные Аля построения экономико-статистических моделей. Количество преАприятий, удовлетворяющих всем ограничениям, составило Аля разных моделей от 54 до 58.

Исходя из задачи исследования, сформирована система зависимых и факторных показателей, представленных в табл. 1, 2.

Система показателей, отражающих прирост

Таблица 1

\section{внеоборотных активов (зависимые переменные) /}

The system of indicators reflecting the growth of non-current assets (dependent variables)

\begin{tabular}{|l|c|}
\hline \multicolumn{1}{|c|}{ Показатель } & Усл. обознач. \\
\hline Приобретение внеоборотных активов на 1 руб. выручки & $\mathrm{Y}_{1}$ \\
\hline Стоимость основных среАств в расчете на 1 руб. совокупных активов, руб. & $\mathrm{Y}_{2}$ \\
\hline Прирост внеоборотных активов на 1 руб. кредитов и займов & $\mathrm{Y}_{3}$ \\
\hline $\begin{array}{l}\text { Аенежный поток, направленный на приобретение основных среАств, } \\
\text { в расчете на 1 руб. основных среАств }\end{array}$ & $\mathrm{Y}_{4}$ \\
\hline Стоимость основных среАств на 1 руб. произведенной продукции & $\mathrm{Y}_{5}$ \\
\hline
\end{tabular}

Источник: составлено авторами / Source: compiled by the authors. 
Таблица 2

\section{Система факторных показателей, используемых Аия построения моделей / The system of factor indicators used to build models}

\begin{tabular}{|c|c|c|c|}
\hline $\begin{array}{c}\text { Группа факторных } \\
\text { показателей }\end{array}$ & Показатель & Расчет показателя & $\begin{array}{c}\text { Усл. } \\
\text { обознач. }\end{array}$ \\
\hline \multirow{6}{*}{$\begin{array}{l}\text { Внеоборотные } \\
\text { активы, в том числе } \\
\text { основные средства } \\
\text { и нематериальные } \\
\text { активы }\end{array}$} & ФонАорентабельность & Чистая прибыль на 1 руб. основных среАств & $X_{1}$ \\
\hline & ФондОотАача & Выручка на 1 руб. основных среАств & $\mathrm{X}_{2}$ \\
\hline & ФонАоемкость & Основные средства на 1 руб. выручки & $\mathrm{X}_{3}$ \\
\hline & $\begin{array}{l}\text { Эффективность } \\
\text { инвестированного капитала }\end{array}$ & $\begin{array}{l}\text { Аобавленная стоимость на } 1 \text { руб. инвестиро- } \\
\text { ванного капитала, рассчитанного как сово- } \\
\text { купные активы компании за вычетом НМА }\end{array}$ & $\mathrm{X}_{4}$ \\
\hline & $\begin{array}{l}\text { ФонАоемкость } \\
\text { (по внеоборотным активам) }\end{array}$ & Внеоборотные активы на 1 руб. выручки & $X_{5}$ \\
\hline & $\begin{array}{l}\text { Аоля нематериальных активов } \\
\text { в совокупной величине активов }\end{array}$ & $\begin{array}{l}\text { Величина НМА в расчете на } 1 \text { руб. совокуп- } \\
\text { ных активов, руб. }\end{array}$ & $X_{6}$ \\
\hline \multirow{3}{*}{ Рентабельность } & Рентабельность активов (ROA) & Чистая прибыль в расчете на 1 руб. активов & $X_{7}$ \\
\hline & $\begin{array}{l}\text { Рентабельность собственного } \\
\text { капитала (ROE) }\end{array}$ & $\begin{array}{l}\text { Чистая прибыль в расчете на } 1 \text { руб. собст- } \\
\text { венного капитала }\end{array}$ & $x_{8}$ \\
\hline & Рентабельность продаж (ROS) & Чистая прибыль в расчете на 1 руб. выручки & $X_{9}$ \\
\hline \multirow{5}{*}{$\begin{array}{l}\text { Финансовая } \\
\text { устойчивость } \\
\text { (Аолгосрочная } \\
\text { платеже- } \\
\text { способность) }\end{array}$} & Коэффициент автономии & $\begin{array}{l}\text { Величина собственного капитала в расчете } \\
\text { на } 1 \text { руб. активов }\end{array}$ & $X_{10}$ \\
\hline & Коэффициент капитализации & $\begin{array}{l}\text { Совокупные обязательства в расчете на } \\
1 \text { руб. собственного капитала }\end{array}$ & $X_{11}$ \\
\hline & $\begin{array}{l}\text { Коэффициент финансовой } \\
\text { устойчивости }\end{array}$ & $\begin{array}{l}\text { Величина собственного капитала и Аолго- } \\
\text { срочных обязательств в расчете на } 1 \text { руб. } \\
\text { активов }\end{array}$ & $X_{12}$ \\
\hline & $\begin{array}{l}\text { Коэффициент финансового } \\
\text { рычага }\end{array}$ & $\begin{array}{l}\text { Величина заемного капитала в расчете на } \\
1 \text { руб. собственного капитала }\end{array}$ & $X_{13}$ \\
\hline & $\begin{array}{l}\text { Коэффициент обеспеченности } \\
\text { собственными оборотными } \\
\text { средствами }\end{array}$ & $\begin{array}{l}\text { Величина собственного капитала за вычетом } \\
\text { внеоборотных активов, приходящаяся на } \\
1 \text { руб. оборотных активов }\end{array}$ & $X_{14}$ \\
\hline \multirow{3}{*}{$\begin{array}{l}\text { ^иквиАность } \\
\text { (краткосрочная } \\
\text { платеже- } \\
\text { способность) }\end{array}$} & Текущая миквиАность & $\begin{array}{l}\text { Величина оборотных активов, приходящихся } \\
\text { на } 1 \text { руб. краткосрочных обязательств }\end{array}$ & $X_{15}$ \\
\hline & Абсолютная ликвиАНость & $\begin{array}{l}\text { Аенежные средства и денежные эквивален- } \\
\text { ты, приходящиеся на } 1 \text { руб. краткосрочных } \\
\text { обязательств }\end{array}$ & $X_{16}$ \\
\hline & Быстрая миквиАНость & $\begin{array}{l}\text { Оборотные активы, уменьшенные на } \\
\text { величину запасов, приходящиеся на } 1 \text { руб. } \\
\text { краткосрочных обязательств }\end{array}$ & $X_{17}$ \\
\hline $\begin{array}{l}\text { ИнАекс платежной } \\
\text { Аисциплины }\end{array}$ & $\begin{array}{l}\text { Показатель, учитывающий } \\
\text { своевременность оплаты } \\
\text { компанией счетов }\end{array}$ & $\begin{array}{l}\text { ИПА, сформированный как комплексный } \\
\text { показатель по методике СПАРК } \\
\text { "Интерфакса" }\end{array}$ & $\mathrm{X}_{18}$ \\
\hline $\begin{array}{l}\text { Индекс финансового } \\
\text { риска }\end{array}$ & $\begin{array}{l}\text { Оценка вероятности } \\
\text { неплатежеспособности } \\
\text { компании }\end{array}$ & $\begin{array}{l}\text { ИФР, сформированный как комплексный } \\
\text { показатель по методике } \\
\text { СПАРК "Интерфакса" }\end{array}$ & $X_{19}$ \\
\hline $\begin{array}{l}\text { Скорость обращения } \\
\text { оборотного капитала }\end{array}$ & Финансовый цикл & Период оборота оборотного капитала & $X_{20}$ \\
\hline
\end{tabular}

Источник: составлено авторами / Source: compiled by the authors.

Исходные Аанные Аля расчета показателей представлены в базе данных СПАРК-Интерфакс в финансовой отчетности предприятий по состоянию на 31.12.2018. В результате анализа построено множество моделей, из которых Аля кажАой из зависимых переменных выбраны статистически качественные модели. В целом можно утверждать о том, что существует связь межАу показателями, принятыми в качестве зависимых переменных, и показателями группы "Финансовая устойчивость". Приведем фрагменты ${ }^{16}$ Авух из

${ }^{16}$ Робастные оценки стандартных ошибок (с поправкой на гетероскедастичность) не приводятся вслеАствие ограниченности объема публикации. 
полученных. Молель (1) построена на 54 наблюдениях, 5 \% критические значения (Авухсторонние) = 0,2681, исправленный R-квадрат = 0,578332. Модель отражает наибольшую зависимость приобретения внеоборотных активов $\left(Y_{1}\right)$ от величины заемного капитала, приходящегося на 1 руб. собственного капитала $\left(\mathrm{X}_{13}\right)$. Это подтверждается также матрицей корреляции (табл. 3). Таким образом, можно утверждать, что показатель, характеризующий приобретение основных среАств, зависит от возможности компании привлекать заемные средства.

$$
\begin{aligned}
& Y_{1}=0,0236+0,0306 * X_{8}-0,00937 * X_{11}+0,0507 * X_{13} \\
& (0,00947)(0,0159) \quad(0,00443) \quad(0,00513)
\end{aligned}
$$

Коэффициенты корреляции дяя переменных модели (1) / Correlation rates for model variables (1)

\begin{tabular}{|c|c|c|c|c|}
\hline$Y_{1}$ & $\mathrm{X}_{8}$ & $\mathrm{X}_{11}$ & $\mathrm{X}_{13}$ & \\
\hline 1,0000 & 0,0467 & $-0,3156$ & 0,7577 & $\mathrm{Y}_{1}$ \\
\hline & 1,0000 & 0,1540 & $-0,1083$ & $\mathrm{X}_{8}$ \\
\hline & & 1,0000 & $-0,3042$ & $\mathrm{X}_{11}$ \\
\hline & & & 1,0000 & $\mathrm{X}_{13}$ \\
\hline
\end{tabular}

Источник: составлено авторами / Source: compiled by the authors.

Как следует из модели (1), большая часть прироста заемных средств, очевидно, направляется на финансирование не основных среАств, а оборотного капитала. Поэтому приведем также модель, построенную Аля показателя $Y_{3}$ (приобретение внеоборотных активов в расчете на 1 руб. кредитов и займов). Уравнение (2) Аемонстрирует, от чего зависит рост $Y_{3}$. Модель построена на основе 58 наблюдений, 5 \% критические значения $($ Авухсторонние $)=0,2586$, исправленный R-квалрат $=0,687031$. Параметры модели представлены в табл. 4.

$$
\begin{aligned}
& Y_{3}=-4,84+0,106 * X_{7}+0,977 * X_{14}+5,07 * X_{20} \\
& \begin{array}{llll}
(0,448) & (0,0329) \quad(0,186) & (0,635)
\end{array}
\end{aligned}
$$

Коэффициенты корреляции дия переменных модели (2) / Correlation rates for model variables (2)

\begin{tabular}{|c|c|c|c|c|}
\hline I_Y3 & $\mathrm{X}_{7}$ & $\mathrm{X}_{14}$ & $\mathrm{X}_{20}$ & \\
\hline 1,0000 & 0,4648 & 0,2722 & 0,7472 & I_Y3 \\
\hline & 1,0000 & $-0,0442$ & 0,4891 & $\mathrm{X}_{7}$ \\
\hline & & 1,0000 & $-0,0975$ & $\mathrm{X}_{14}$ \\
\hline & & & 1,0000 & $\mathrm{X}_{20}$ \\
\hline
\end{tabular}

Источник: составлено авторами / Source: compiled by the authors.

Как показывает модель (2), увеличение доли внеоборотных активов при получении заемного финансирования связано с такими факторами, как рентабельность активов по чистой прибыли $\left(X_{7}\right)$, обеспеченность оборотных активов собственными средствами $\left(X_{14}\right)$ и Алительность финансового цикла $\left(\mathrm{X}_{20}\right)$. Полученные связи можно интерпретировать слеАующим образом: предприятие увеличивает Аолю заемного финансирования, направляемого на обновление основных среАств, при условии Аостаточного уровня отАачи на активы, а также достаточной обеспеченности оборотных активов собственными среАствами Ааже при росте Алительности периода оборота оборотного капитала (финансового цикла). 
Аругими словами, в первую очередь предприятия решают проблему текущего управления и достаточности оборотных средств и лишь затем начинают направлять финансовые ресурсы на обновление основных среАств и приобретение Аругих внеоборотных активов.

Полученные результаты позволяют утвержАать, что программу переоснащения промышленных предприятий в целях улучшения экологических показателей необходимо проводить с учетом их финансовых возможностей, поскольку наилучшие доступные технологии требуют не только начальных инвестиций на их внедрение и запуск, но и более высоких текущих затрат на их поддержание. Чтобы эти дополнительные расходы не были переложены на потребителей через цены на продукцию и не стали очередной причиной роста инфляции, на этапе подготовки к внеАрению принципов "зеленого" финансирования необходимы предварительные исследования и расчеты затрат на осуществление этих программ. На наш взгляА, продуктивным было бы наличие и подАержка со стороны государства пилотных (экспериментальных) проектов с возможностью исследования их результатов, а также формирования системы показателей Аля будущего регулярного статистического учета основных экологических и экономических параметров функционирования преАприятий в новых условиях.

\section{ЗАКАЮЧЕНИЕ}

В качестве итогов исследования сформулируем выводы.

1. Россия нацелена на последовательный переход к "зеленой" экономике, что нашло отражение в национальном проекте "Экология" и, в частности, в федеральном проекте "Наилучшие Аоступные технологии". Воплощение в жизнь этих планов предполагает привлечение значительного объема финансирования, выбора источников и инструментов, наиболее полно отвечающих запросам всех участников инвестиционного процесса. Появление на отечественном финансово-кредитном рынке “зеленых" инструментов актуализирует задачу выработки методологии "зеленого" финансирования обновления основного капитала.

2. Изучение особенностей "зеленых" инвестиций показало, что принципиальным заказчиком, гарантом и соинвестором выступает государство, которое устраняет разрыв межАу индивиАуальными интересами инвесторов и комективными проблемами общества. Анализ формирующегося институционального оформления "зеленого" финансирования указывает на необходимость институциализации и гармонизации экосистемы "зеленых" инвестиций в соответствии с выработанными мировой практикой стандартами. Требуется выработать единые подходы, критерии и правила развития, а также инструменты оценки эффективности, подАержки и стимулирования "зеленых" инвестиций. Сравнение отАельных методологических принципов традиционного и "зеленого" финансирования показало, что характерной особенностью процесса "зеленого" финансирования является триединство элементов "объект - субъект - институциональная среда", в совокупности характеризующих специфику “зеленых" инвестиций.

3. Внедрение в России наилучших Аоступных технологий Аля предприятий, и в первую очередь из перечня 300 преАприятий-загрязнителей, необходимо проводить с учетом их финансовых возможностей. Моделирование, проведенное с целью оценки факторов, влияющих на прирост внеоборотных активов (основного капитала) преАприятий из списка 300, в том числе факторы, связанные с источниками их финансирования, показало следующее. В первую очередь преАприятия решают проблему текущего управления и Аостаточности оборотных среАств и лишь затем начинают направлять финансовые ресурсы на обновление основных среАств и приобретение Аругих внеоборотных активов. При реализации программы внеАрения НАТ важно, чтобы дополнительные расходы не были переложены на потребителей через цены на продукцию и не стали причиной роста инфляции. 
Таким образом, развитие «зеленого" финансирования в России с целью обновления основного капитала предприятий на принципах наилучших Аоступных технологий преАполагает:

- совершенствование институциональных условий “зеленого" финансирования, делающих возможными и стимулирующих частные инвестиции при широком использовании бюАжетных средств;

- сочетание усиливающейся обеспокоенности состоянием окружающей среды и изменением климата с устойчивой экономической отдачей финансируемых "зеленых" проектов, что предполагает гармонизацию национальных и международных стандартов "зеленого" инвестирования;

- развитие теории и методологии "зеленого" кредитования с целью расширения масштабов "зеленого" финансирования и предложения "зеленых" продуктов предприятиям и организациям, осуществляющим модернизацию и техническое перевооружение на принципах наилучших Аоступных технологий.

\section{Список источников}

Аовбий И. П. Принципы кредитного обеспечения инвестиционно-инновационных процессов региона: монография. Челябинск: ИзАательский центр ЮУрГУ, 2011. 259 с.

Аовбий И. П. Промышленность России: инвестиционно-инновационное развитие и экономическая безопасность: монография. Челябинск: Издательский центр ЮУрГУ, 2018. 240 с.

Кабир ^. С. Социально ответственное инвестирование: тренА ияи временное явление? // Экономика. Налоги. Право. 2017. № 4. С. 35-41.

Кабир ^. С. Государственная поддержка “зеленых" инвестиций и рыночное "зеленое" финансирование: зарубежный опыт // Инноватика и экспертиза: научные труды. 2019. № 1 (26). С. 97-108.

Карелов С. В., Белик И. С., Стародубец Н. В. Экологический потенциал наилучших доступных технологий // Экономика региона. 2012. № 4. С. 60-68. URL: https://doi.org/10.17059/2012-4-6.

Недосекин А. О. Финансовые рынки и финансирование предприятий МСК в современных условиях, 2012. URL: https://present5.com/finansovye-rynki-i-finansirovanie-predpriyatij-msk-v-sovremennyx/.

Яковлев И. А., Кабир ^. С. Механизм финансирования "зеленых" инвестиций как элемент национальной стратегии финансирования устойчивого развития // Научно-исслеАовательский финансовый институт. Финансовый журнал. 2018. № 3. С. 9-20. URL: https://doi.org/10.31107/2075-1990-2018-3-9-20.

Яковлев И. А., Кабир ^. С., Раков И. А. «Зеленые» инвестиции в России: основные тенАенции // Экономика: теория и практика. 2017. № 3 (47). С. 66-75.

Поступила в редакцию 21 июля 2020 г. Принята к публикации 19 августа 2020 г.

\section{References}

Dovbiy I.P. (2011). The Principles of Credit Provision of Investment and Innovative Processes in the Region: monograph. Chelyabinsk: SUSU Publ., 259 p. (In Russ.).

Dovbiy I.P. (2018). Russian Industry: Investment and Innovation Development and Economic Security: monograph. Chelyabinsk: SUSU Publ., 240 p. (In Russ.).

Kabir L.S. (2017). Socially Responsible Investing: a Trend or a Temporary Phenomenon? Ekonomika. Nalogi. Pravo - Economy. Taxes. Rings, no. 4, pp. 35-41 (In Russ.).

Kabir L.S. (2019). State Support for Green Investments and Market Green Financing: Foreign Experience. Innovatika i ekspertiza: nauchnyye trudy - Innovatics and Expertise: Scientific Works, no. 1 (26), pp. 97-108 (In Russ.).

Karelov S.V., Belik I.S., Starodubets N.V. (2012). Ecological Potential of the Best Available Technologies. Ekonomika regiona - Economy of the Region, no. 4, pp. 60-68 (In Russ.). Available at: https://doi.org/10.17059/2012-4-6.

Nedosekin A.O. (2012). Financial Markets and Financing of MSK Enterprises in Modern Conditions (In Russ.). Available at: https://present5.com/finansovye-rynki-i-finansirovanie-predpriyatij-msk-v-sovremennyx/.

Yakovlev I.A., Kabir L.S. (2018) Green Investment Financing Mechanism as an Element of the National Strategy for Sustainable Development Financing. Finansovyy zhurnal - Financial Journal, no. 3, pp. 9-20 (In Russ.). Available at: https://doi.org/10.31107/2075-1990-2018-3-9-20.

Yakovlev I.A., Kabir L.S., Rakov I.D. (2017). Green Investments in Russia: Main Trends. Ekonomika: teoriya i praktika - Economy: Theory and Practice, no. 3 (47), pp. 66-75 (In Russ.). 


\title{
ESG-критерии в инвестировании: зарубежный и отечественный опыт
}

\author{
Екатерина Олеговна Вострикова, к. э. Н., Аоцент, Аоцент кафеАры экономи- \\ ческой теории Астраханского государственного университета, г. Астрахань \\ E-mail: Katrin-16@yandex.ru, ORCID 0000-0002-5844-8305 \\ Анна Павловна Мешкова, к. э. н., Аоцент, Аоцент кафедры экономической \\ теории Астраханского государственного университета, г. Астрахань \\ E-mail: Anna.meshkova_82@mail.ru, ORCID 0000-0003-1788-5581
}

\begin{abstract}
Аннотация
Эволюция финансовых инструментов наполняет новым содержанием процесс принятия инвестиционных решений. Современное общество предъявляет спрос на дополнительную информацию относительно деятельности компаний: его уже не удовлетворяет стандартная финансовая отчетность и финансовые показатели. Ухудшение состояния окружающей среды, глобальное потепление, борьба с бедностью на фоне роста благосостояния в развитых странах создают благоприятную почву Аля появления и развития новых финансовых инструментов и критериев. В качестве ответа на эти современные запросы выступают ESG-критерии, способные помочь оценить деятельность компаний, связанную с инвестированием в устойчивое развитие. Более того, применение этих критериев позволяет компаниям снижать риски, создавать репутацию, равно как инвестиционным фондам помогает в принятии качественных инвестиционных решений. Эта тенденция, возникшая и укрепившаяся в развитых зарубежных странах за последние 50 лет, проникает и на развивающиеся рынки.

Аанная статья посвящена исследованию роли ESG-критериев в принятии инвестиционных решений с учетом накопленного зарубежного опыта. Аидерами в социально ответственном инвестировании являются экономики развитых стран: США, Канады, Великобритании, Германии, Австралии. Так как российские компании стремятся получить международное финансирование, им придется конкурировать за инвесторов на зарубежных финансовых рынках на их условиях. Следовательно, имеет смысл уже сейчас ориентироваться на следование ESG-критериям в своей деятельности.

Выявлены проблемы, сАерживающие проникновение ESG-критериев в процесс принятия инвестиционных решений в России. САелан вывод о том, что в настоящее время существует ряд барьеров Аля внедрения данных критериев: недостаток понимания значимости социально ответственных инвестиций, отсутствие государственных стандартов в раскрытии нефинансовой информации, дефицит крупных внутренних инвесторов (отсутствие конкуренции на рынке пенсионного страхования), нацеленность российских компаний иск^ючительно на получение среднесрочной прибыли.
\end{abstract}

Ключевые слова: социально ответственные инвестиции, ESG-критерии, "зеленые" инвестиции, инвестиционные фонды, риски, устойчивое инвестирование

JEL: G11

Аля цитирования: Вострикова Е. О., Мешкова А. П. ESG-критерии в инвестировании: зарубежный и отечественный опыт // Финансовый журнал. 2020. T. 12. № 4. C. 117-129. DOI: 10.31107/ 2075-1990-2020-4-117-129. 
DOI: 10.31107/2075-1990-2020-4-117-129

\title{
ESG Criteria in Investment: Foreign and Russian Experience
}

\section{Ekaterina 0. Vostrikova ${ }^{1}$}

E-mail: Katrin-16@yandex.ru, ORCID 0000-0002-5844-8305

Anna P. Meshkova ${ }^{1}$

E-mail: Anna.meshkova_82@mail.ru, ORCID 0000-0003-1788-5581

${ }^{1}$ Astrakhan State University, Astrakhan 414056, Russian Federation

\section{Abstract}

The evolution of financial instruments improves investment decision-making. Modern society requires additional information about companies' activities: standard financial statements and financial indicators no longer satisfy its needs. Environmental degradation, global warming, and the fight against poverty amid growing prosperity in developed countries - all these factors promote the development of new financial instruments and criteria. ESG provides the answer to these modern demands and can help evaluate companies' activities related to investment in sustainable development. Moreover, the application of these criteria enables companies to reduce risks and to create reputation, and helps investment funds make quality investment decisions. This trend, which has emerged and strengthened in developed foreign countries over the past 50 years, is penetrating emerging markets as well.

This article investigates the role of ESG criteria in making investment decisions based on foreign experience. The leaders in socially responsible investment are the economies of developed countries: the USA, Canada, Great Britain, Germany, and Australia. As Russian companies seek international financing, they will have to compete for investors in foreign financial markets on their terms. Therefore, it makes sense to focus on following ESG criteria in their activities right now.

Currently, there are a number of barriers to the implementation of ESG criteria in Russia: lack of understanding of the importance of socially responsible investments, lack of state standards in the disclosure of non-financial information, lack of large domestic investors (lack of competition on the pension insurance market as well), and the focus of Russian companies only on medium-term profits.
\end{abstract}

Keywords: socially responsible investment, ESG criteria, green investment, investment funds, risk, sustainable investment

JEL: G11

For citation: Vostrikova E.O., Meshkova A.P. ESG Criteria in Investment: Foreign and Russian Experience. Financial Journal, 2020, vol. 12, no. 4, pp. 117-129 (In Russ.). DOl: 10.31107/2075-1990-2020-4117-129.

\section{BВEAEHИE}

Неоклассические модели микроэкономики определяют экономическую эффективность фирмы в качестве ключевого критерия Аля оценивания целесообразности инвестиций. ОАнако, как показывает практика последнего десятилетия, это не всегда так. Постепенно на первый план выступают так называемые ESG-критерии (Environmental, Social, Governance - экология, социальное развитие, управление). То есть Аля того чтобы считаться успешной, фирма Аолжна не только демонстрировать устойчивый рост финансовых показателей, но и обладать определенной репутацией. Клиентам, инвесторам, потребителям (экономическим агентам в целом) становится интересна и важна философия фирмы.

Казалось бы, в терминах экономики развития можно говорить о том, что У. Ростоу бы^ прав и современное общество, пройдя пять стадий роста и преодолев эпоху массового потребления (the age of high mass consumption), вступило в шестую стадию - стадию поиска качества жизни, гАе на первый план выступают моральные и этические ценности 
и духовное развитие мичности. ОАнако применение ESG-критериев при принятии инвестиционных решений имеет и практическое значение, например позволяет инвестору снижать вероятность риска. В настоящее время растет число зарубежных финансовых компаний, которые в своих публичных отчетах детально раскрывают принципы, по которым они работают, в частности, как они используют принципы ESG в своей деятельности и как это отражается на доходности их портфелей. К числу таких компаний относятся такие известные, как JPMorgan Chase, Wells Fargo, Goldman Sachs, и др. Нефинансовая информация, связанная с охраной окружающей среды и социальной ответственностью фирм, все чаще используется при принятии решений инвестиционными фондами. А фирмы, в свою очередь, привлекают в свой штат отАельных специалистов по ESG.

В современных условиях (интерес к проблеме изменения климата, пандемия COVID-19, борьба с коррупцией, борьба за равенство полов и проч.) практика применения критериев социально ответственного инвестирования будет распространяться. Соответственно, Аля привлечения инвесторов российским фирмам необходимо стремиться соответствовать критериям ESG. Вероятно, это особенно важно Аля крупных Аобывающих компаний, чья Аеятельность потенциально связана с институциональными рисками и рисками загрязнения окружающей среды.

\section{ПОНЯТИЕ ЕSG-КРИТЕРИЕВ И ПРИЧИНЫ ИХ ИНТЕГРАЦИИ В ПРОЦЕСС ПРИНЯТИЯ ИНВЕСТИЦИОННЫХ РЕШЕНИЙ}

В начале 1960-х гг. в Европе и Северной Америке инвесторы начали выдвигать требования обеспечения не только определенной нормы дохода, но и соответствия объекта инвестиций ряду социальных, экологических и этических критериев, а также соблюдения опреАеленных норм корпоративного управления [Кабир ^. С., 2017]. Причинами повышенного внимания инвесторов к целям, на которые расходуются вкладываемые ими деньги, стали напряженная политическая обстановка в мире (региональные военные конфликты, тяжелая экологическая обстановка в Европе, связанная с ростом промышленного производства), а также глобализация мировой экономики и финансов, которая обеспечила тесную взаимосвязь между финансовым инвестированием и задачами соблюдения общественных интересов. Инвесторы осознали, что при оценке инвестиций необходимо учитывать их возАействие на общество и окружающую среАу, при этом это возАействие Аолжно быть ответственным и приводить к положительному результату [Кабир $\Lambda$. С., 2017]. Аля этого они начали использовать ESG-критерии, которые учитывают социальные, экологические и управленческие факторы при оценке инвестиционных проектов.

Социально ответственное инвестирование - процесс принятия инвестиционных решений, учитывающий в рамках традиционного финансового анализа социальные и экомогические послеАствия инвестиций [Батаева Б. С., Вавилина А. В., 2016, с. 16]. В рамках "Концепции организации в России методологической системы по развитию зеленых финансовых инструментов и проектов ответственного инвестирования" приводится слеАующая трактовка критериев ESG: “ESG - экологические и социальные факторы, а также факторы корпоративного управления <...> которые соблюдают в своей деятельности компании и организации всех форм собственности и которые учитывают институциональные инвесторы и финансирующие организации в своих инвестиционных стратегиях и кредитных политиках" ${ }^{1}$.

Фактически речь илет о том, чтобы учитывать социальные и экологические послеАствия деятельности фирмы (как положительные, так и отрицательные) и интегрировать их в классический процесс принятия инвестиционных решений. Основная причина

\footnotetext{
1 https://cbr.ru/Content/Document/File/84163/press_04102019.pdf.
} 
внимания к ESG-критериям в том, что инвесторы, государственные органы и сами фирмы верят, что применение этих критериев позволяет выявить факторы (нефинансового характера), которые могут оказывать Аолгосрочное влияние на деятельность фирмы (ее финансовые показатели) в лучшую или в худшую сторону. В результате применения ESGкритериев выявляются и финансируются инвесторами те фирмы, Аеятельность которых отвечает определенным стандартам корпоративной социальной ответственности, этическим нормам и которые зарабатывают определенный репутационный капитал в глазах потребителей и общества в целом.

Интерес к социально ответственным инвестициям возник еще 50 лет назаА [Sparkes R., Cowton C. J., 2004]. А уже в период с 2000 по 2010 г. количество исследований, касающихся причин и послеАствий применения ESG-критериев при принятии инвестиционных решений, существенно возросло [Chelawat H., Trivedi I. V., 2013]. В настоящее время можно говорить о том, что применение ESG-критериев прочно вошло в практику инвесторов развитых стран и постепенно находит своих сторонников на развивающихся рынках.

Можно утверждать, что интерес инвесторов (а также финансируемых ими фирм) к применению критериев ESG отражает спрос экономических агентов на нефинансовую информацию [Батаева Б. С., 2015]. Так как в большинстве стран государство регулирует раскрытие компаниями именно финансовой информации, показатели, связанные с данными критериями, обычно раскрываются компаниями на добровольной основе.

Как правило, нефинансовая информация связана с такими темами, как:

- экология: изменение климата, истощение природных ресурсов, загрязнение окружающей среды, уменьшение площади лесов, вымирание видов и Ар.;

- социальное развитие: условия труда, использование детского и рабского труда, соблюдение техники безопасности на рабочем месте, вредные условия труда, соблюдение прав человека, Аискриминация на рабочем месте (при приеме на работу), ответственность переА обществом и лр.;

- корпоративное управление: отношение к коррупции, налоговая стратегия, оплата труда топ-менеАжеров, структура управляющего состава, прозрачность управления и Ар.

Эти три компонента сегоАня играют важную роль при принятии инвестиционных решений. Некоторые исследователи демонстрируют, что институциональные инвесторы (в том числе пенсионные фонды) очень серьезно относятся к рискам, связанным с экологией [Ilhan E. et al., 2020]. Внимание к проблеме изменения климата также связано с рисками инвесторов в Аолгосрочной перспективе [Bansal R. et al., 2016]. Аемонстрация фирмой своей социальной ответственности положительно сказывается на лояльности ее клиентов и может усиливать рыночную власть фирмы, снижая еe риски [Albuquerque R. et al., 2019] и делая ее привлекательной в глазах инвесторов.

Внимание к некоторым элементам управления инвестициями на основе ESGкритериев имеет логичное и понятное объяснение. В частности, фирмы обычно Аемонстрируют устойчивое развитие, если они хорошо управляются, если их сотруАники уАовметворены поведением руководства [Edmans A., 2011] или если права собственников обеспечены и защищены [Gompers P. et al., 2003].

Кроме того, само по себе инвестирование с использованием ESG-критериев оказывает позитивный социальный эффект. Во-первых, социально ответственное инвестирование усиливает взаимодействие межАу экономическими агентами и предотвращает провалы координации [Oehmke M., Орр М. М., 2020]. Во-вторых, применение ESG-критериев в инвестировании пробуждает интерес у самих фирм к "зеленым" технологиям, так как их инвесторы заинтересованы в таких технологиях [Pastor L. et al., 2020]. Кроме того, издержки инвестиционных фонАов, связанные с получением информации по ESG-критериям, а также с рисками, меньше или равны издержкам, которые несут инвесторы в случае "традиционного" инвестирования [Wallis M., Klein C., 2015]. Таким образом, у фирмы 
не образуются чистые потери при применении инструментов, связанных с социально ответственным инвестированием.

\section{ЕSG-КРИТЕРИИ: МЕЖАУНАРОАНАЯ СТАТИСТИКА ПРИМЕНЕНИЯ}

Согласно международной практике нефинансовая информация - это экологическая, социальная информация и информация в области корпоративного управления, ее наличие влияет на оценку прозрачности компании. Раскрытие нефинансовой информации по принципу триединого итога, то есть по экологическим, социальным и экономическим аспектам деятельности, происходит в большей мере Аобровольно, осуществляется в годовом отчете, в нефинансовом отчете, на официальном сайте компании и с использованием Аругих Аоступных среАств коммуникации [Батаева Б. С., 2015, с. 263].

Оценка инвестирования с помощью ESG-факторов в последние годы набирает обороты. В частности, в 2017 г. британская компания Schroders провела опрос среди 22 тыс. инвесторов со всего мира. Результаты исследования показали, что Аля 80 \% опрошенных вложение Аенежных среАств в компании, которые придерживаются принципов социально ответственного поведения, стало гораздо важнее, чем пять лет назаА ${ }^{2}$.

В конце 2018 г. компанией Ernst \& Young проведено исследование, которое было направлено на изучение связи между нефинансовыми факторами (ESG-факторами) и принятием инвестиционных решений и охватило более 200 инвесторов со всего мира. Полученные данные показали, что при оценке инвестиционных проектов большинство инвесторов полагаются именно на нефинансовые показатели (в 2018 г. около 97 \% инвесторов оценивали инвестиционные проекты с помощью ESG-критериев, в то время как в 2017 г. это значение составило 78 \%). Исследование также выявило, что в 2018 г. только 3 \% инвесторов вообще не интересовались ESG-критериями при оценке инвестиционных проектов, в то время как в 2017 г. этот показатель составлял 22 \%, а в 2015 г. - 48 \%, что говорит о широком распространении и применении ESG-критериев ${ }^{3}$.

В 2019 г. американская компания BlackRock провела опрос среди своих клиентов (более 230 организаций в сфере государственных и частных пенсионных фондов, страховых компаний и благотворительных организаций, под управлением которых находятся более 7 трлн Аомм.). 51 \% респондентов ответили, что они решили пересмотреть свою инвестиционную политику в 2020 г., 27 \% заявили о растущей важности ESG-критериев при оценке инвестиционных проектов ${ }^{4}$.

Если в 2006 г., когАа были сформулированы «Принципы ответственного инвестирования ООН (PRI)", насчитывалось только 63 инвестиционные компании (поА управлением которых находилось 6,5 трлн Аомл. США), поАписавшие обязательство учитывать факторы ESG при принятии инвестиционных решений, то в 2018 г. таких организаций насчитывалось уже 1715 (под их управлением находилось более 81,7 трлн Аолм.). По Аанным исслеАования FTSE Russell, в 2018 г. около половины всех мировых инвесторов использовали принципы ESG при инвестировании ${ }^{5}$. Следует обратить внимание, что оценки различных рейтинговых агентств и консалтинговых компаний отличаются, это может быть вызвано тем, что Аанные организации принимают во внимание разный набор данных при анализе нефинансовой информации компаний.

2 EY Global Financial Accounting and Advisory Services (FAAS) corporate reporting survey, 2018. URL: https:// assets.ey.com/content/dam/ey-sites/ey-com/en_gl/topics/assurance/assurance-pdfs/2018-EY-Global-FinancialAccounting-Advisory-Services-Corporate-Reporting-Survey.pdf.

${ }^{3}$ EY Global Financial Accounting and Advisory Services (FAAS) corporate reporting survey, 2018.

${ }^{4} 2020$ Institutional Rebalancing Survey. URL: https://www.blackrock.com/institutions/en-ch/insights/ rebalancing-survey.

${ }^{5}$ ESG Ratings. URL: https://www.ftserussell.com/data/sustainability-and-esg-data/esg-ratings. 
В 2018 г. Amundi Asset Management выяснила, что относительная значимость факторов ESG зависит от региона. Так, в США большую роль уАеляют проблеме защиты окружающей среды, а в странах Европы - качеству управления. В 2019 г. компания PwC опросила 165 ведущих инвесторов из 35 стран и пришла к выводу, что самыми главными факторами, которые влияют на их инвестиционное решение, стали бизнес-этика (89 \%), коррупция и воровство (87 \%), а также охрана и пожарная безопасность (83 \%). Наименее значимым фактором стала работа с волонтерами (13\%).

В 2019 г. французская компания Natixis Investment Managers предоставила результаты исследования, в котором принимали участие 9,1 тыс. индивидуальных инвесторов, 2,7 тыс. специалистов в сфере финансов, 500 институциональных инвесторов, 200 инвесторов, преАставляющих инвестиционные фонды из 28 стран мира. Результаты исследования показали, что все эти инвесторы уделяют значительное внимание экологическим, социальным факторам, а также факторам корпоративного управления при принятии решений об инвестировании.

Согласно Глобальному обзору устойчивого инвестирования (GSIA) за 2018 г. активы устойчивого инвестирования в начале 2018 г. превысили 30 трлн Аомл. США во всем мире, то есть выросли на 34 \% с 2016 г. По состоянию на ноябрь 2019 г. уже более 2600 организаций подписали «Принципы ответственного инвестирования ООН (PRI)", при этом только в 2018-2019 гг., согласно годовому отчету PRI за 2019 г., к "Принципам» присоединилось более 500 новых организаций

В структуре инвесторов преобладают институциональные, но их доля на рынке ответственных инвестиций постепенно сокращается. Так, в 2012 г. они аккумулировали $89 \%$ рынка, тогАа как в начале 2018 г. их Аоля снизилась Ао 75 \%. Чаще всего Аля целей ответственного инвестирования используется исключающий скрининг, который при этом является ведущей стратегией только в Европе, тогАа как Аля США, КанаАы, Австралии и Новой Зеландии в основном характерна ESG-интеграция, а Аля Японии - вовлечение акционеров [^ьвова Н. А., 2019, с. 62].

Рисунок 1

\section{Соотношение частных и институциональных ответственных инвестиций / Ratio of private and institutional responsible investments}

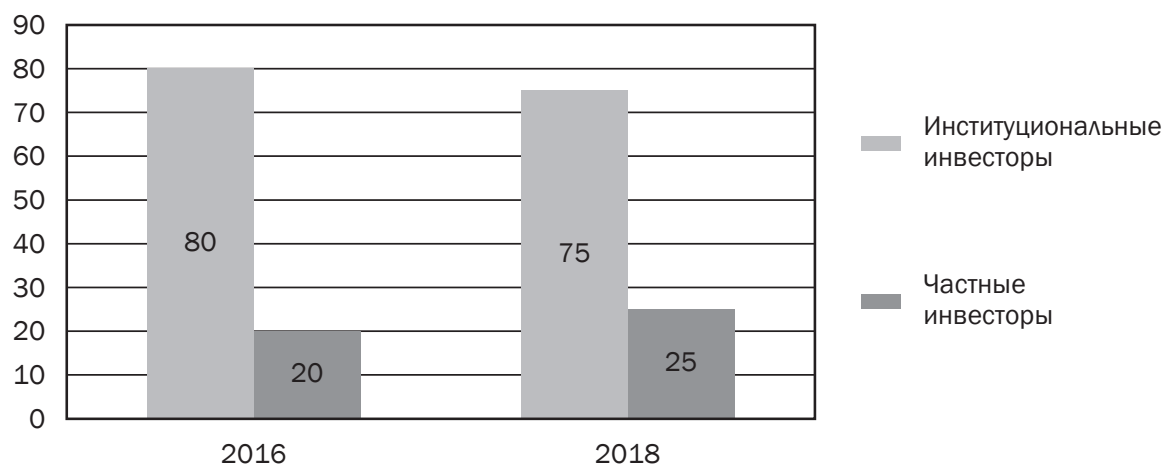

Источник: Global Sustainable Investment Review 2018, с. 12 (http://www.gsi-alliance.org/wp-content/uploads/ 2019/03/GSIR_Review2018.3.28.pdf).

${ }^{6}$ ESG факторы в инвестировании, 2019. URL:https://www.pwc.ru/ru/sustainability/assets/pwc-responsibleinvestment.pdf.

7 Концепция организации в России методологической системы по развитию зеленых финансовых инструментов и проектов ответственного инвестирования, 2019. URL: https://cbr.ru/Content/Document/File/84163/ press_04102019.pdf. 
Сегодня на Аолю инвестиций в ESG приходится около четверти всех профессионально управляемых фондов по всему миру. В обществе растет понимание того, что рейтинги ESG являются показателем как долгосрочной деятельности компании, включая Аоходность и риск, так и морально-этических ценностей, которым следует компания.

Тема социально ориентированного инвестирования за рубежом важна не только Аля частных, но и Аля государственных инвесторов. Так, в 2019 г. Государственный пенсионный фонд Центрального банка Нидерландов решил снизить "углеродный слеА" своего инвестиционного портфеля на $10 \%$, а также отказаться от вложений в акции производителей табака и оружия. Этому примеру послеАова^ и Норвежский государственный пенсионный фонА.

ПереА заключением сделки ответственный инвестор проводит анализ с помощью ESG-факторов. Аанный подход позволяет оценить риски, связанные с инвестициями, а также возможности компании в Аолгосрочной перспективе. Принимая решение о вложениях денежных средств, инвесторы обращают внимание на соблюАение Парижского соглашения и наличие нефинансовой отчетности, которую согласно директиве Европейского союза Аолжны иметь все публичные компании ЕС, число сотрудников в которых превышает 500 человек.

\section{ГЕОГРАФИЧЕСКОЕ РАСПРЕАЕАЕНИЕ СОЦИААЬНО ОТВЕТСТВЕННЫХ ИНВЕСТИЦИЙ}

Более половины глобальных инвестиций осуществляется на основе ESG-критериев. K странам-лидерам, осуществляющим социально ответственные инвестиции, относятся США, Великобритания, Канада и страны континентальной Европы. В странах Азии Аанная тенденция складывалась не такими значительными темпами. Так, в 2016 г. объем ESG-инвестиций в азиатских странах составил всего лишь 500 млн Аомл. США.

В отчете Global Sustainable Investment Alliance упомянуто, что за период с 2014 по 2016 г. объем социально ответственных инвестиций в США увеличился на 33 \% и составил приблизительно 8,7 трлн Аом.. В Европе объем инвестиций за тот же периоА увеличился на $22 \%$ и Аостиг 12 млрА Аом.. США ${ }^{8}$. С 2016 по 2018 г. объемы социально ответственных инвестиций в целом по миру увеличились на треть и составияи 30,7 трлн Аолм., из которых 26 трлн приходились на Европу и США.

США являются оАним из лиАеров, занимающихся ответственным и устойчивым инвестированием. Государством было направлено около 46,6 трлн Аомл. на социальное инвестирование; 365 управляющих капиталом и 1145 ^окальных инвестиционных компаний США занимаются устойчивым и социальным инвестированием. По данным финансового издания Barron's, к самым успешным компаниям США, которые ориентируются на принципы ESG, относятся: ретейлер бытовой и цифровой техники Best Buy, высокотехнологичная компания Cisco, производитель медицинского оборудования Agilent Technologies, компания НР и производитель электроники Texas Instruments 9 . Основным стимулом, который побудил инвесторов США к вложению денежных средств в социально ответственные проекты, стало активное вк^ючение ESG-критериев в стратегии компаний [Кабир ^. С., 2017, c. 38].

Согласно данным Global Sustainable Investment Review в 2018 г. более 25 \% инвестиций в США можно отнести к социально ответственному инвестированию.

8 Global Sustainable Investment Review, 2016. URL: https://www.ussif.org/files/Publications/GSIA_Review 2016.pdf.

9 The No. 1 Company in Key Sectors of Barron's 100 Most Sustainable Companies / Barron 's, 2020. URL: https://www.barrons.com/articles/the-no-1-company-in-key-sectors-of-barrons-100-most-sustainable-companies51581600600. 


\section{Аоля устойчивых инвестиций по отношению к общему объему управляемых активов в 2018 г. / Share of sustainable investments in total amount of managed assets in 2018}

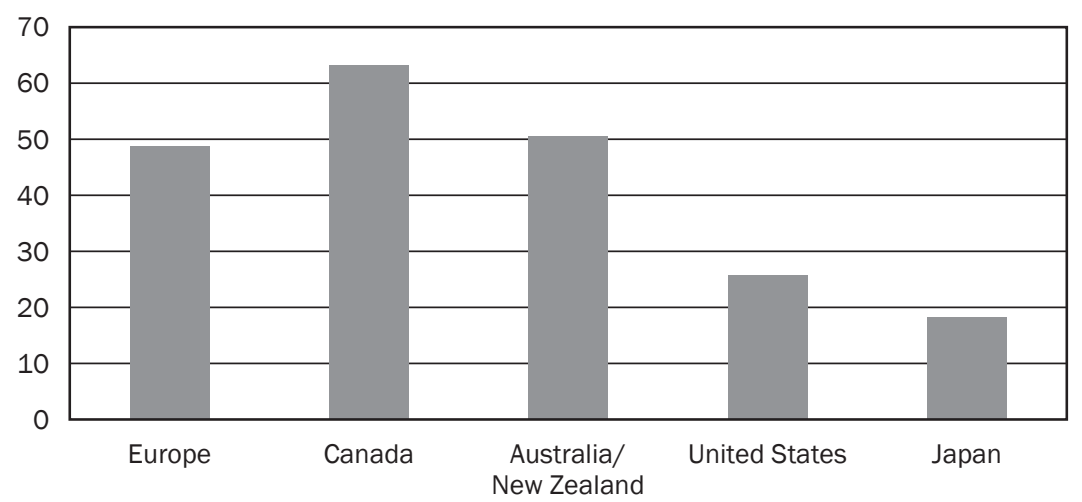

Источник: Global Sustainable Investment Review 2018, с. 8 (http://www.gsi-alliance.org/wp-content/uploads/ 2019/03/GSIR_Review2018.3.28.pdf).

Почти половина инвестиций развитых стран Европы относится к социально ответственным. И хотя этот показатель Аля стран Европы снизился по сравнению с 2016 г. (58,8 \% в 2016 г. по сравнению с 48,8 \% в 2018-м), это скорее связано с изменением стандартов и ужесточением правил отнесения инвестиций к разряду ответственных, чем с падением интереса к этому типу инвестирования.

Великобритания является одной из крупнейших стран, которые занимаются ответственным инвестированием. В 2012 г. создан Зеленый инвестиционный банк (Green Investment Bank, GIB), который занимается софинансированием "зеленых" проектов совместно с частными инвесторами. В 2019 г. банк выделил более 20 млрА фунтов стерлингов на рециркуляцию воды, морскую ветроэнергетику и энергосбережение.

Около 96 \% всех социальных инвестиций Австралии направляются на защиту окружающей среды. В 2015 г. управляющий инвестиционный фонА Social Ventures Australia совместно с пенсионным фонАом HESTA созАали крупнейший фонА, занимающийся ESG-инвестированием. Совокупный объем "зеленых" облигаций Австралии составляет 15,6 м^рА Аомл. Приоритетными сферами инвестирования яв^яются энергетика, водные ресурсы и переработка отходов.

С 2015 по 2017 г. объем социальных инвестиций Канады увеличился с 8,15 млрА Аомл. США Ао 14,75 млрА. В 2017 г. в стране была создана открытая платформа Openlmpact, которая связывает инвесторов, желающих вложить среАства Аля получения не только Аохода, но и социального, а также экологического эффекта. В 2020 г. на Аанной платформе было зарегистрировано около 107 фондов, занимающихся инвестированием на основе ESG-критериев.

Рынок социального инвестирования Германии представлен преимущественно частными корпорациями. Наиболее крупными фондами, которые вкладывают денежные среАства на основе ESG-критериев, являются такие фонды, как BMW Stiftung Herbert Quandt и BonVenture. По данным исследования Forum Nachhaltige Geldanlagen, объем социальных инвестиций Германии в 2018 г. составил 13 млрд Аомм. США. Аенежные средства в основном идут на решение социальных и экологических проблем, а также на благотворительность ${ }^{10}$.

\footnotetext{
${ }^{10}$ FNG Marktbericht Nachhaltige Geldanlagen, 2018. URL: https://www.forum-ng.org/de/.
} 
Следует отметить, что новый формат инвестирования формирует реакцию компаний, стремящихся привлечь заемные среАства. Они начинают следить за тенденциями на мировом рынке, настроениями частных и корпоративных инвесторов и, соответственно, меняют свое стратегическое поведение.

Австралийская энергокомпания AGL объявила о прекращении функционирования угольных электростанций к 2022 г. Вместо угля компания намерена использовать альтернативные источники: солнечную энергию, энергию воды и ветра. Аанная политика способствует не только защите экологии, но и предоставляет возможность сокращения издержек.

Британский некоммерческий фонА ShareAction проводил опрос среди 500 крупных инвесторов. Более 50 \% респондентов ответили, что социально ответственное инвестирование может способствовать росту доходности инвестиций, а также принести пользу Аля репутации компании ${ }^{11}$. В то же время противоречие принципам ESG может приводить к падению стоимости акций компании, как это произошло в 2013 г. с акциями Barrick Gold. Компания занимается добычей золота. Власти Чили обнаружили, что компания сливает производственные отходы в реку, и оштрафовала проект на 16 млн Аомл. Похожая ситуация имела место с акциями немецкого автоконцерна Volkswagen, когАа стало известно, что автоконцерн подтасовывает данные о вредных выхлопах своих автомобилей и, следовательно, нарушает закон о чистоте воздуха.

При ответственном инвестировании чаще всего используется стратегия искяючения, суть которой заключается в избавлении от активов, которые связаны с игорным бизнесом, производством табака, алкоголя, оружия и так Аалее. Так, в 2016 г. французская страховая компания AXА сообщила о продаже принаАлежащих ей ценных бумаг табачных компаний на сумму 1,8 млрА евро и прекращении инвестирования в табачную промышменность. В 2017 г. перестраховочная компания SwissRe заявила о том, что ее инвестиционный портфель размером 130 млрА Аолл. США будет направлен на проекты, которые соответствуют ESG-критериям. В 2018 г. 985 институциональных инвесторов из 37 стран в рамках ответственного инвестирования иск^ючили из своих портфелей ценные бумаги на сумму 6,24 трлн Аомл.

В некоторых странах, например в Швеции, Испании, Аействуют законодательные требования к госпредприятиям публиковать нефинансовые отчеты, а во Франции - к крупным компаниям и компаниям с госучастием. Отдельные зарубежные фондовые биржи ввели требования в правила мистинга (Йоханнесбургская фондовая биржа) или рекомендации Аля эмитентов по публикации отАельных показателей в области нефинансовой информации по принципу "СоблюАай или объясни" (Лондонская фондовая биржа и Ар.) [Батаева Б. С., 2015, с. 263].

Учет ESG-факторов позволяет фондам, которые занимаются ESG-инвестициями, принять взвешенное решение об инвестировании в ценные бумаги какой-либо компании. Это означает, что инвестиционные фонды, которые оценивают проекты с помощью ESGкритериев, способствуют осуществлению социально ориентированного бизнеса, опосредованно заботятся об окружающей среде, а также отличаются качественным управлением. Все это положительно сказывается на репутации инвестиционного фонда.

\section{ПРОБАЕМЫ ВНЕАРЕНИЯ ЕSG-КРИТЕРИЕВ В ПРАКТИКУ РОССИЙСКИХ КОМПАНИЙ}

В России концепция социально ответственного инвестирования находится на начальном этапе своего развития. Причины этого - недостаточная информированность инвесторов,

${ }^{11}$ ShareAction / Annual Review 2016. URL: https://shareaction.org/resources/annual-review-2016/. 
а также ограниченная Аоступность экологической, социальной и управленческой информации о компаниях Аля принятия инвесторами финансовых решений.

Исследование, проведенное Ассоциацией ответственного инвестирования PRI в 2017-2018 гг., показало, что российские компании уделяют большое внимание вопросам корпоративного управления, но практически не интересуются аспектами социальной и экологической ответственности ${ }^{12}$. Вероятно, это связано с преимущественной ориентацией российского бизнеса на получение прибыли в коротком периоде. Так, 81 \% российских респонАентов считают, что вопросы корпоративного управления влияют на Аоходность акций в большей степени, нежели другие критерии.

В ходе исследования были выявлены основные ограничения, препятствующие внеАрению ESG-инвестирования в российскую практику. Это, например, непонимание или неточное понимание самой проблематики ESG и влияния Аанных факторов на Аолгосрочную финансовую Аеятельность ${ }^{13}$. ОАнако это характерно Аля многих стран. В качестве меры, которая может способствовать ослаблению этого барьера, могут выступать форумы, конференции, Аеловые мероприятия, направленные на разъяснение вопросов использования факторов ESG при анализе деятельности компаний с учетом национальной специфики и лучших зарубежных практик.

ОАним из основных барьеров на пути к успешным социально ориентированным инвестициям в России является также отсутствие Аоступа к качественной и объективной нефинансовой информации, которая описывала бы деятельность компаний по устойчивому развитию, однако ситуация быстро меняется.

Кроме того, на сегодняшний день в России отсутствует сильная база институциональных инвесторов в лице пенсионных фондов и страховых компаний, которые в Аругих странах мира формируют основной спрос на развитие рынка ESG-инвестирования. Запрос на использование критериев ESG и раскрытие нефинансовой информации прихоАит к российским фирмам в основном от зарубежных инвесторов. ОАнако из-за финансовых санкций и опасений возможных дополнительных штрафов в случае взаимодействия с российскими кампаниями, которые пока не включены в санкционные списки, но могут туда попасть, спрос на такую информацию весьма ограничен. Поэтому российским компаниям нет смысла активно слеАовать ESG-принципам.

Следует отметить, что в условиях пандемии и последующего экономического кризиса позволить себе нести финансовые риски, связанные с внедрением принципов социально ответственного инвестирования, в России могут преимущественно крупные организации, у которых есть соответствующая "подушка безопасности" или гарантия подАержки от государства (статус системообразующих). ОАнако и в относительно спокойный период развития экономики в России (2015-2019 гг. и ранее) список организаций, участвующих в социальных и "зеленых" проектах, был относительно небольшим.

Тем не менее активность в этих направлениях прогрессирует. В частности, крупные нефтяные компании (например, ОАО “Газпром нефть", ПАО "ЛУКОЙЛ») участвуют в благоустройстве территорий и инфраструктуры населенных пунктов, осуществляют финансовую подАержку учебных заведений, участвуют в проектах по развитию безбарьерной среды (ОАО "МегаФон"), решают экологические проблемы (Банк "Открытие», Банк "Центринвест») и т. А. В конце 2018 г. ООО “Ресурсосбережение ХМАО" завершило размещение на Московской бирже “зеленых" облигаций, фактически став первым эмитентом в России на основе Green Bond Principle ICMA.

\footnotetext{
${ }^{12}$ Global Sustainable Investment Review 2018. URL: http://www.gsi-alliance.org/wp-content/uploads/2019/ 03/GSIR_Review2018.3.28.pdf.

${ }^{13}$ Там же.
} 
Примечательно, что вопросами экологии интересуются не только ресурсодобывающие компании, Аеятельность которых связана с "грязными" технологиями, но и компании из сферы информационных технологий. В частности, специалисты East Capital высоко оценивают усилия "Яндекса" в этом направлении: сервер обработки данных "Яндекса", расположенный в Финляндии, направляет излишки тепла на отопление жилых Аомов. Если ранее такая Аеятельность компании была бы отнесена к разряду благотворительности, то в настоящее время она считается частью стратегии социального инвестирования и нацелена на получение конкретных результатов в Аолгом периоде [Крючкова О. А., 2015].

Хотя российские компании все еще не привыкли, что принципы социальной, корпоративной, этической и экологической ответственности становятся фактором оценки стоимости их акций, запрос общества на применение этих критериев присутствует [Савина Т. Н., 2015]. Повышается финансовая грамотность населения, меняется философия ведения бизнеса, растет интерес бизнеса к социальной ответственности, ухудшается экологическая обстановка (неравномерно от региона к региону) - все вышеобозначенные процессы так или иначе способствуют формированию спроса на внедрение ESG-критериев в российскую практику инвестирования. Следует отметить, что Аля рейтингов ESG не важны финансовые показатели компаний, что также пока непривычно Аля российского бизнеса.

\section{ЗАКАЮЧЕНИЕ}

Таким образом, эффективность применения ESG-критериев в практике инвестирования в России будет зависеть от целого ряда факторов:

- понимание значимости социально ответственных инвестиций в российском бизнессообществе;

- транспарентная и последовательная государственная политика в области устойчивого развития территорий, в том числе стандартизация и контроль за раскрытием финансовой и нефинансовой информации компании;

- создание конкурентной среды и ориентация экономических агентов на разработку инвестиционных стратегий, исходя из концепции "Алинных" Аенег.

Следовательно, инвестиции, ориентированные на ESG, - это не просто кратковременное желание угодить общественности. Компания, которая Аействует ответственно, управляется с целью стратегического развития. Это означает, что она может служить надежным объектом Аля инвестиций. Влияние факторов ESG на стоимость российских компаний, скорее всего, возрастет. Чем больше инвесторов и аналитиков следят за корпоративной ответственностью компаний, тем более важную роль станут играть факторы ESG. Сейчас инвестиции ESG обычно приводят к снижению доходности - инвестор ограничен в выборе инструментов. С Аругой стороны, тенденция ESG может привести к невостребованности ценных бумаг некоторых российских компаний на финансовых рынках. Таким образом, применение ESG-критериев, которое вначале может показаться "следованием моде", в перспективе станет аспектом выживания компаний на мировом рынке. Фактически сегодня у российских компаний есть выбор: остаться на внутреннем рынке и довольствоваться ограниченными финансовыми ресурсами или эволюционировать Ао уровня мировой конкурентоспособной компании, слеАуя новым финансовым тенденциям.

С начала 2020 г. наблюдается рост интереса к исследованиям в области медицины, биологии, психологии. В сложившихся условиях государства и частные инвесторы значительно увеличили свои расходы в данном направлении. Компании, стремящиеся привлечь среАства инвесторов (частных и институциональных), имеют стимулы к применению и развитию ESG-критериев (экологические, социальные вопросы, морально-этические 
ценности становятся более актуальными). Государство стремится смягчить послеАствия пандемии, выступая соинвестором Аля тех компаний, Аействия которых помогают сохранить занятость, стабилизировать экономическое и социальное положение в стране, подАержать Аостойный уровень медицинских услуг, а также научные и прикладные исслеАования Аля борьбы с COVID-19. Все это способствует росту интереса к социально ответственному инвестированию со стороны фирм и применению ESG-критериев со стороны инвестиционных фонАов.

\section{Список источников}

Батаева Б. С. Оценка интереса инвесторов к нефинансовой информации публичных компаний. Зарубежный опыт // Управленческие науки в современном мире. 2015. № 1. С. 262-266.

Батаева Б. С., Вавилина А. В. Зарубежная практика развития социально ответственных инвестиций // Известия Саратовского университета. Новая серия. Серия “Экономика. Управление. Право». 2016. № 1. C. 15-23. URL: https://doi.org/10.18500/1994-2540-2016-16-1-15-23.

Кабир ^. С. Социально ответственное инвестирование: тренА или временное явление? // Экономика и управление. 2017. № 4. С. 35-41.

Крючкова О. А. Устойчивое инвестирование в контексте мировых финансовых рынков // Научно-методический электронный журнал “Концепт». 2015. Спецвыпуск № 3. URL: http://e-koncept.ru/2015/75066.htm.

^ьвова Н. А. Ответственные инвестиции: теория, практика, перспективы Аля Российской Федерации // Научный журнал НИУ итMО. Серия “Экономика и экологический менеАжмент». 2019. № 3. C. 56-67. URL: https://doi.org/10.17586/2310-1172-2019-12-3-56-67.

Савина Т. Н. Концептуальные основы исследования социально ответственного инвестирования // Экономический анализ: теория и практика. 2015. № 9 (408). С. 52-62.

Albuquerque R., Koskinen Y., Zhang C. Corporate Social Responsibility and Firm Risk: Theory and Empirical Evidence // Management Science. 2019. Vol. 65. Iss. 10. P. 4451-4469. URL: https://doi.org/10.1287/mnsc. 2018.3043.

Bansal R., Ochoa M., Kiku D. Climate Change and Growth Risks / NBER Working Papers w23009, 2016.

Chelawat H., Trivedi I. V. Ethical Finance: Trends and Emerging Issues for Research // International Journal of Business Ethics in Developing Economies, 2013. Vol. 2. Iss. 2. Publishing India Group. URL: https://ssrn.com/ abstract $=2850010$.

Edmans A. Does the stock market fully value intangibles? Employee satisfaction and equity prices // Journal of Financial Economics. 2011. Vol. 10 (3). P. 621-640.

Gompers P., Ishii J., Metrick A. Corporate Governance and Equity Prices // Quarterly Journal of Economics. 2003. Vol. 118 (1). P. 107-156.

Ilhan E., Sautner Z., Vilkov G. Carbon Tail Risk / Review of Financial Studies (forthcoming), 2020. URL: http:// dx.doi.org/10.2139/ssrn.3204420.

Pastor L., Stambaugh R. F., Taylor L. A. Sustainable Investing in Equilibrium / NBER Working Paper No. w26549, 2020.

Oehmke M., Opp M. M. A Theory of Socially Responsible Investment / Swedish House of Finance Research Paper. 2020. No. 20-2. URL: https://doi.org/10.2139/ssrn.3467644.

Sparkes R., Cowton C. J. The Maturing of Socially Responsible Investment: A Review of Developing Link with Corporate Social Responsibility // Journal of Business Ethics. 2004. Vol. 56. Iss. 1. P. 45-57. URL: https:// doi.org/10.1023/B:BUSI.0000033106.43260.99.

Wallis M., Klein C. Ethical requirement and financial interest: a literature review on socially responsible investing // Business Research. 2015. Vol. 8. Iss. 1. P. 61-98. URL: 10.1007/s40685-014-0015-7.

Поступила в редакцию 11 июня 2020 г. Принята к публикации 19 августа 2020 г.

\section{References}

Albuquerque R., Koskinen Y., Zhang C. (2019). Corporate Social Responsibility and Firm Risk: Theory and Empirical Evidence. Management Science, vol. 65, iss. 10, pp. 4451-4469. Available at: https://doi.org/ 10.1287/mnsc.2018.3043.

Bataeva B.S. (2015). Evaluation of Investor's Interest in the Non-Financial Information of Public Companies. Foreign experience. Upravlencheskie nauki v sovremennom mire - Management Sciences in the Modern World, iss. 1, pp. 262-266 (In Russ.). 
Bataeva B.S., Vavilina A.V. (2016). Foreign Practice of Socio Responsible Investment. Izvestiya Saratovskogo universiteta. Novaya seriya. Seriya Ekonomika. Upravlenie. Pravo - Izvestiya of Saratov University. New series. Series: Economics. Management. Law, vol. 1, pp. 15-23 (In Russ.). Available at: https://doi.org/10.18500/19942540-2016-16-1-15-23.

Bansal R., Ochoa M., Kiku D. (2016). Climate Change and Growth Risks. NBER Working papers w23009.

Chelawat H., Trivedi I.V. (2013). Ethical Finance: Trends and Emerging Issues for Research. International Journal of Business Ethics in Developing Economies, vol. 2, iss. 2. Available at: https://ssrn.com/abstract=2850010.

Kabir L.S. (2017). Socially Responsible Investing: a Trend or a Temporary Phenomenon? Ekonomika. Nalogi. Pravo - Economics. Taxes. Law, vol. 4, pp. 35-41 (In Russ.).

Edmans A. (2011). Does the stock market fully value intangibles? Employee satisfaction and equity prices. Journal of Financial Economics, vol. 101 (3), pp. 621-640.

Gompers P., Ishii J., Metrick A. (2003). Corporate Governance and Equity Prices. Quarterly Journal of Economics, vol. 118 (1), pp. 107-156.

Ilhan E., Sautner Z., Vilkov G. (2020). Carbon Tail Risk. Review of Financial Studies (forthcoming). Available at: http://dx.doi.org/10.2139/ssrn.3204420.

Kryuchkova O.A. (2015). Sustainable Investment in the Context of Global Financial Markets. Concept. Special issue № 3 (In Russ.). Available at: http://e-koncept.ru/2015/75066.htm.

Lvova N.A. (2019). Responsible Investments: Theory, Practice, Prospects for the Russian Federation. Nauchnyi zhurnal NIU ITMO. Seriya Ekonomika i ekologicheskii menedzhment - The scientific journal NRU ITMO. Series Economics and Environmental Management, vol. 3, pp. 56-67 (In Russ.). Available at: https://doi. org/10.17586/2310-1172-2019-12-3-56-67.

Oehmke M., Opp M.M. (2020). A Theory of Socially Responsible Investment. Swedish House of Finance Research Paper. No. 20-2. Available at: https://doi.org/10.2139/ssrn.3467644.

Pastor L., Stambaugh R.F., Taylor L.A. (2020). Sustainable Investing in Equilibrium. NBER Working Paper No. w26549.

Savina T.N. (2015). Conceptual Foundations of the Research Methodology of Socially Responsible Investment. Ekonomicheskii analiz: teoriya i praktika - Economic Analysis: Theory and Practice, vol. 9 (408), pp. 52-62 (In Russ.).

Sparkes R., Cowton C.J. (2004). The Maturing of Socially Responsible Investment: A Review of Developing Link with Corporate Social Responsibility. Journal of Business Ethics, vol. 56, iss. 1, pp. 45-57. Available at: https:// doi.org/10.1023/B:BUSI.0000033106.43260.99.

Wallis M., Klein C. (2015). Ethical requirement and financial interest: a literature review on socially responsible investing. Business Research. vol. 8, iss. 1, pp. 61-98. Available at: https://doi.org/10.1007/s40685-014-0015-7.

Received 11.06.2020

Accepted for publication 19.08.2020 


\section{Фничи}

Финансовый журнал

\section{Уважаемые коммеги! \\ Приглашаем к сотрудничеству с “Финансовым журналом"}

"Финансовый журнал" - рецензируемое научно-практическое издание, выхоАит с 2009 года. МежАународные стандартные номера сериального издания: ISSN 2075-1990 (Print) и ISSN 2658-5332 (Online).

Учредитель и издатель - федеральное государственное бюджетное учреждение "Научно-исследовательский финансовый институт Министерства финансов Российской Федерации", г. Москва.

Главный редактор - Аиректор НИФИ Минфина России Владимир Назаров.

"Финансовый журная" вк^ючен в Перечень ВАК, входит в базы Аанных: РИНЦ, RePEc, Ulrich's Periodicals Directory, Open Academic Journals Index.

Издание публикует материалы по следующим темам: финансы (бюджетная система, межбюАжетные отношения, разработка и реализация бюАжетной, Аенежно-кредитной и налоговой политики), финансовые рынки, страхование, банковская сфера, бухгалтерский учет и аудит, финансовый контроль, статистика, а также макроэкономическое моделирование и международные финансы.

Все статьи публикуются в журнале БЕСПААТНО. Статьям присваиваются цифровые идентификаторы объектов - Dol (Digital Object Identifier).

Тексты всех статей размещаются в открытом доступе на сайте "Финансового журнала" www.finjournal-nifi.ru и на портале Научной электронной библиотеки (НЭБ) www.elibrary.ru

Издание выходит 6 раз в год (февраль, апрель, июнь, август, октябрь, декабрь).

www.finjournal-nifi.ru

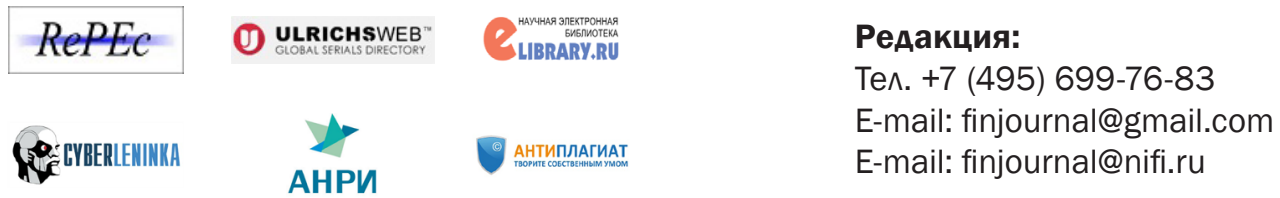




\section{Правима приема научных статей}

1. K публикации принимаются научные статьи и аналитические обзоры, соответствующие тематике журнала, ранее не публиковавшиеся и не предназначенные к одновременной публикации в Аругих изданиях.

2. Редакция не оказывает авторам платных услуг. Публикация статей производится на безвозмездной основе. Плата за публикацию не взимается, вознаграждение авторам не выплачивается.

3. Направляя рукопись научной статьи или аналитического обзора (Аалее - статья) в редакцию, авторы выражают свое согласие на ее редактирование (литературное, техническое), публикацию и размещение в открытом доступе в сети Интернет, в т. ч. на сайте "Финансового журнала» www.finjournal-nifi.ru и на портале НЭБ www.elibrary.ru.

4. Статья направляется в редакцию в электронном виде. Вместе со статьей авторы преАставляют в электронном виде сопроводительное письмо.

5. Требования к оформлению статьи разработаны на основании Методических рекоменАаций АНРИ.

5.1. Статья оформляется в текстовом редакторе MS Word, расширение - .docx. Шрифт - Times New Roman, кегль 14 или 12. Поля страницы (верхнее и нижнее - 20 мм, левое - 30 мм, правое - 15 мм). Номер страницы проставляется внизу листа, посредине. Объем текста - от 30 до 50 тыс. знаков с пробелами. Формулы и символы набираются в формульном редакторе MS Word. Рисунки (графики, диаграммы), выполненные в Excel, PowerPoint и др. программах, прилагаются отдельными файлами.

5.2. В начале статьи на русском языке приводятся: Ф.И.О. авторов, название статьи, сведения об авторах, аннотация, ключевые слова, коды JEL, благодарности (при необходимости). Аля каждого автора указывается аАрес электронной почты, ученая степень, ученое звание (при их наличии), Аолжность (Аолжности), название учреждения (организации), город с почтовым индексом, страна. В аннотации указывают: актуальность темы исследования, цели, методы, результаты исследования и главные выводы, основные ключевые слова. Объем аннотации - 150-200 слов. Ключевые слова - 7-9.

5.3. Текст статьи должен включать: введение, основную часть (методы исследования, результаты, обсуждение), заключение и список источников (библиографию). Таблицы и рисунки Аолжны быть пронумерованы и озаглавлены. Названия рисунков, таблиц и подписи поА ними (источники) привоАятся на русском и английском языках. Список источников не менее 15.

5.4. Ссылки на журналы, книги, монографии, сборники и пр. необходимо оформлять внутри текста статьи (в квалратных скобках). Редакция использует "гарвардский" стиль: сначала указывается фамилия и инициалы автора или авторов (при отсутствии авторов название публикации или фамилия и инициалы редактора), затем через запятую - гоА издания цитируемого источника.

Если цитируемому источнику присвоен DOI (цифровой иАентификатор объекта), нужно его указывать. Список источников приводится в конце статьи по алфавиту. Цитирование нормативных правовых документов, газетных статей и т. п. следует оформлять только в виде подстраничных ссылок и в список источников не включать.

5.5. Завершается статья блоком информации на английском языке. Он включает: Ф.И.О. авторов (транслитерация), название статьи, аффилиацию авторов, аннотацию (Abstract) 200-250 слов, ключевые слова (Keywords), коды JEL, благодарности (Acknowledgments) и список источников (References).

6. Статьи, не соответствующие требованиям пп. 1-5 настоящих Правил, к рассмотрению не принимаются. 


\title{
Уважаемые читатели и авторы!
}

Подписку на "Финансовый журна^" вы можете оформить в мюбом отАелении почтовой связи России по ОбъеАиненному каталогу “Пресса России». ПоАписной индекс 42068.

Аоставку ^юбого номера журнала первого и второго полугодия 2020 г. вы можете заказать по интернет-каталогу "Российская периодика" на сайте www.arpk.org. Телефон Аля справок (499) 152-04-90.

\section{Редакция:}

Главный редактор В. С. Назаров

Ведущий редактор Т. М. Захарова

Корректор И. П. Белова

Аизайн и верстка А. С. Аухин

Редактор английского текста А. С. Нечаева

\author{
Адрес редакции: \\ Настасьинский пер., А. 3, стр. 2, Москва 127006, Россия \\ Тел. (495) 699-76-83 \\ E-mail: finjournal@gmail.com \\ Сайт: www.finjournal-nifi.ru
}

Подписано в печать 21.08.2020. Свободная цена. Тираж 200 экз. Заказ № 2058-20 Отпечатано в соответствии с предоставленными материалами в ООО “Амирит". 